ANNA FLÁVIA FELDMANN

Análise das campanhas de comunicação sobre Câncer de Mama - um estudo comparativo entre as iniciativas do INCA e do IBCC 


\title{
Análise das campanhas de comunicação sobre Câncer de Mama - um estudo comparativo entre as iniciativas do INCA e do IBCC
}

\author{
Dissertação apresentada ao Programa de Pós- \\ Graduação em Ciências da Comunicação, Área \\ de Concentração Interfaces Sociais da \\ Comunicação, Linha de Pesquisa em Políticas e \\ Estratégias da Comunicação, da Escola de \\ Comunicações e Artes da Universidade de São \\ Paulo, como exigência parcial para obtenção do \\ Título de Mestre em Ciências da Comunicação, \\ sob a orientação da Prof ${ }^{\mathrm{a}}$. Dr ${ }^{\mathrm{a}}$. Clotilde Perez.
}




\begin{abstract}
AUTORIZO A REPRODUÇÃO E DIVULGAÇÃO TOTAL OU PARCIAL DESTE TRABALHO, POR QUALQUER MEIO CONVENCIONAL OU ELETRÔNICO, PARA FINS DE ESTUDOS E PESQUISA, DESDE QUE CITADA A FONTE.
\end{abstract}

Ficha Catalográfica

Feldmann, Anna Flávia.

Análise das campanhas de comunicação sobre Câncer de Mama - um estudo comparativo entre as iniciativas do INCA e do IBCC / Anna Flávia Feldmann. - São Paulo : A.F. Feldmann, 2008.

Xxx f.

Dissertação (Mestrado) - Escola de Comunicações e Artes/USP, 2008.

Orientadora: Prof ${ }^{\mathrm{a}}$. Dr ${ }^{\mathrm{a}}$. Clotilde Perez.

Bibliografia

1. Comunicação 2. Estudos de gênero 3. Câncer de Mama 4. Semiótica 5. Saúde pública feminina. I. Feldmann, Anna Flávia II. Título.

CDD 21.ed. 302 


\section{FOLHA DE APROVAÇÃO}

\section{ANNA FLÁVIA FELDMANN}

Análise das campanhas de comunicação sobre

Câncer de Mama - um estudo comparativo

entre as iniciativas do INCA e do IBCC

Dissertação apresentada à Escola de Comunicações e Artes

da Universidade de São Paulo, como exigência parcial

para obtenção do Título de Mestre.

BANCA EXAMINADORA 
Este trabalho é dedicado a todos os profissionais empenhados em construir um cotidiano mais simétrico entre a comunicação social e a realidade humana. 


\section{Agradecimentos}

Aos meus pais e minha família, pelo exemplo e amor.

À Clotilde Perez, pela constante elucidação e apoio.

Ao Waldo Lao, pelo entendimento e companheirismo.

Ao CNPq e à ECA-USP, pela bolsa de estudos em incentivo aos meus estudos e a minha dissertação.

À Fátima Meireles, do Inca, pelas informações e por permitir acesso ao material da pesquisa.

Às minhas amigas mestrandas, Joseane Terto, Joseleide Terto e Carla Rabelo, grandes presentes que a universidade me proporcionou. 
É preciso atrair violentamente a atenção para o presente do modo como ele é se quer transformá-lo.

Pessimismo da inteligência, otimismo da vontade.

Antonio Gramsci 


\section{Resumo}

A informação é uma grande aliada na vida da mulher com câncer de mama, não apenas para comentar sobre feminilidade, auto-estima e qualquer outra questão de ordem social e psicológica inerente à realidade da doença, mas também para promover a educação sobre o assunto e divulgar o acesso aos direitos relativos à saúde pública feminina.

As peças de publicidade sobre câncer de mama ganharam amplo espaço na mídia em geral, o que constitui uma responsabilidade significativa assumida pelos veículos de comunicação e por profissionais da área. Todavia, importa analisar de que maneira as propagandas desenvolvidas incorporam elementos potenciais de transgressões comportamentais, informações que em máximo grau de entendimento poderiam prevenir, curar e diminuir a mortalidade por câncer de mama.

A pesquisa analisa as iniciativas publicitárias de controle da doença câncer de mama no Brasil, verificando as suas ocorrências nas diferentes mídias existentes, bem como os discursos adotados no cenário da comunicação de massa, articulando tais assuntos às questões de gênero.

Por meio da junção da linha de pesquisa semiótica e de teóricos críticos da comunicação de massa espera-se averiguar o processo de emissão publicitária. Sendo assim, serão contrapostos os conceitos sociológicos da difusão das mensagens com a análise das peças destinadas à mulher para o embasamento da argumentação teórica. Optou-se também pela adoção de autores ligados às áreas sociológicas do câncer de mama e das questões de gênero.

Foram consideradas ações publicitárias sobre a doença idealizadas pelo Ministério da Saúde por meio do Inca - Instituto Nacional de Câncer e pelas iniciativas do Instituto Brasileiro de Controle do Câncer - IBCC. Pretende-se verificar com a pesquisa qual é a contribuição das ações comunicativas às perspectivas de melhoria da condição social da mulher, destacando se as peças desenvolvidas mobilizam a sociedade para o assunto, quais os benefícios alcançados decorrentes desse acesso à informação e se os efeitos da campanha atingem a sociedade como um todo, influenciando na erradicação e prevenção da doença.

Palavras-chave: Comunicação; estudos de gênero; câncer de mama; semiótica; saúde pública feminina. 


\begin{abstract}
Information is a great ally to a woman who has got breast cancer, not only to tell her about femininity, self-esteem or some social or psychological questions regarding the reality of the disease, but also to provide education about that matter and help her have access to the women's rights related to public health.

The publicity pieces about breast cancer have got large space in the overall media, which means great responsibility taken by communication means and professionals. However, it is important to analyze to what extent the pieces contain potential elements for behavior changes and information that could prevent, cure and decrease breast cancer mortality if they were fully understood.

The present research analyzes the advertising initiatives concerning the control of breast cancer in Brazil, by checking their occurrences in the different media as well as the speeches adopted for mass communication and the articulation of those matters to gender issues.

By joining the semiotic research line and mass communication critical theoreticians, the present work aims at investigating the advertising process. So, the messages sociological concepts will be opposed to the analysis of the pieces towards the women to have the basis for theoretical argumentation. Some authors who deal with social aspects of breast cancer and gender issues will also be referred.

The present research focused publicity initiatives about the disease taken by Ministério da Saúde through Inca - Instituto Nacional de Câncer and IBCC - Instituto Brasileiro de Controle do Câncer. The research aims at checking if communication actions contribute to the perspective of improving the woman's social condition, if they help the society become aware of that matter, if the information they provide generate benefits and if the campaigns reach the whole society and influence the erradication and prevention of the disease.
\end{abstract}

Keywords: Communication; Gender Studies; Breast Cancer; Semiotic; Feminine Public Health. 


\section{Lista de ilustrações}

Figura 1 - Eva Prima Pandora. 29

Figuras 2 e 3 - Obras representativas de antigas manifestações artísticas de feminilidade e maternidade... 64

Figura 4 - Primeiros tratamentos de raio-X para o cancer de mama............................. 65

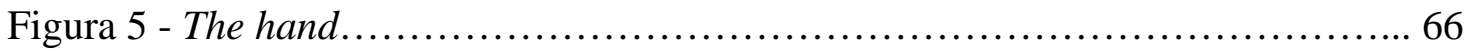

Figura 6 - Desfile homossexual em São Francisco, EUA.............................................70

Figura 7 - Propaganda divulgada no jornal O Globo em 24/11/1982............................ 78

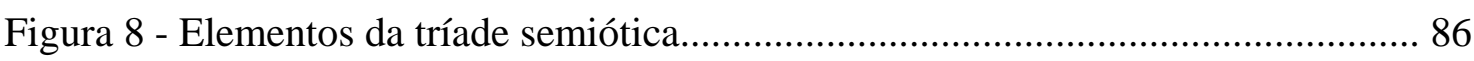

Figura 9 - Identidade visual da marca O câncer de mama no alvo da moda.................. 93

Figura 10 - Exemplo de produto licenciado da marca O Câncer de Mama no Alvo da

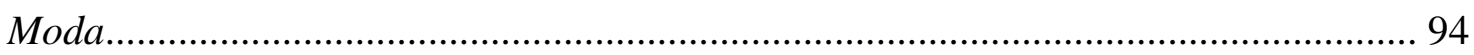

Figura 11 - Corrida e Caminhada Contra o Câncer de Mama...................................... 94

Figura 12 - Foto de revista com a modelo Gisele Bündchen.......................................... 96

Figura 13 - Exemplo de propaganda no site do IBCC.................................................. 97

Figura 14 - Exemplo de propaganda em outdoor da campanha do IBCC..................... 97

Fígura 15 - Atriz Adriana Lessa na página do site IBCC na qual constam todos os atores e personalidades famosas participantes da campanha........................................ 97

Figuras 16, 17 e 18 - Modelos da campanha e as diferentes adaptações do símbolo da

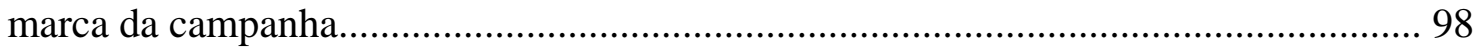

Figura 19 - Quadro sobre a proposta de valor da campanha O Câncer de Mama no Alvo

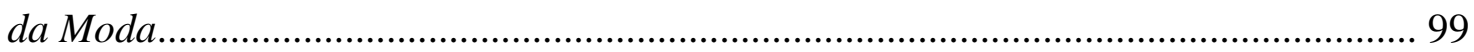

Figura 20 - Quadro das cores mais e menos apreciadas........................................... 101

Figura 21 - Possíveis associações do processo criativo do símbolo da campanha $O$

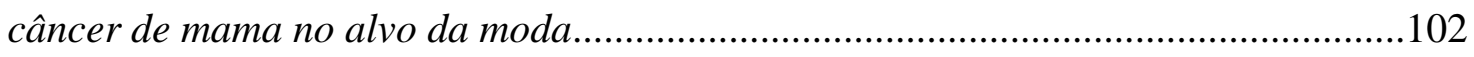

Figura 22 - Tríade semiótica da marca da campanha O câncer de mama no alvo da moda

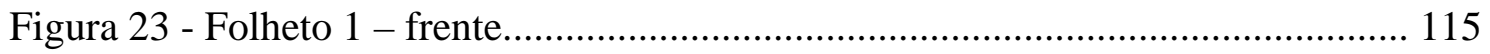

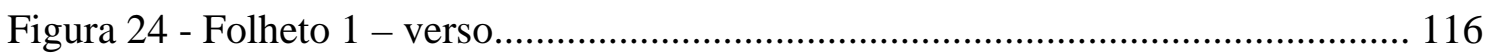

Figura 25 - Folheto 2 - frente................................................................... 117

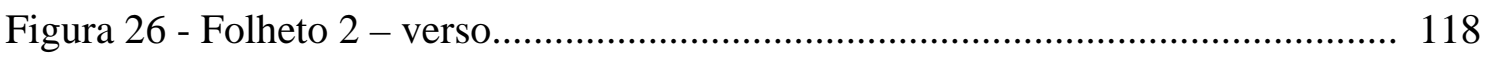

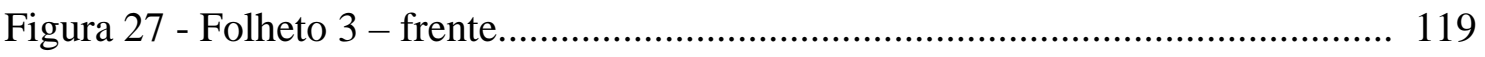


Figura 28 - Folheto 3 - verso.. 120

Figura 29 - Folder 1 - Capa ............................................................................... 122

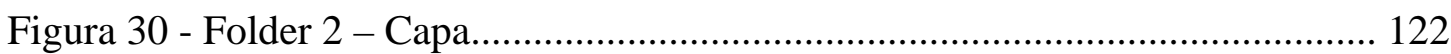

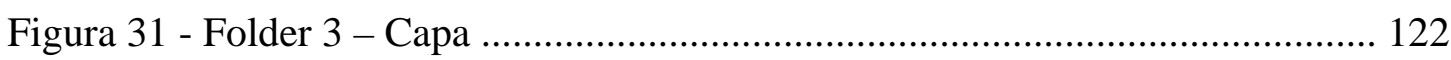

Figura 32 - Exemplos de páginas interiores dos folders 1, 2 e 3.............................. 123

Figura 33 - Fita cor-de-rosa da campanha do Programa Viva Mulher...................... 124

Figura 34 - Cena do comercial veiculado sobre a campanha do Programa Viva

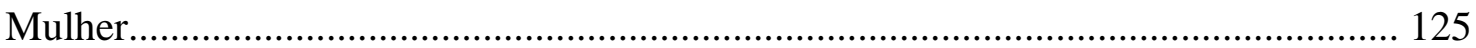

Figura 35 - Cartaz da campanha do Programa Viva Mulher........................................ 133

Figura 36 - Folhetos da campanha do Programa Viva Mulher.................................... 134

Figura 37 - Folders para profissionais de saúde da campanha do Programa Viva

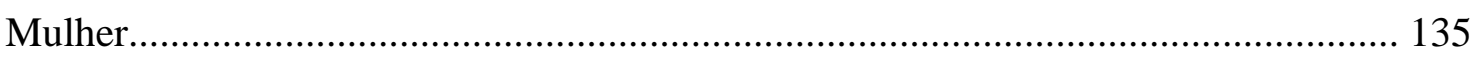

Figura 38 - Outdoors da campanha do Programa Viva Mulher................................... 136

Figura 39 - Intervenções urbanas da campanha do Programa Viva Mulher................ 137

Figura 40 - Ponto de distribuição de fitas cor-de-rosa da campanha do Programa Viva Mulher. 138

Figuras 41, 42, 43 e 44 - Frente, verso, contracapa e $3^{\mathrm{a}}$ capa de folheto da campanha do Programa Viva Mulher já com a inclusão do Câncer de Mama 144

Figura 45 - Interior de folheto da campanha do Programa Viva Mulher já com a inclusão do Câncer de Mama 145

Figuras 46 e 47 - Capa dos materiais técnicos desenvolvidos pelo Programa Viva Mulher distribuídos a profissionais dos postos de saúde 146

Figuras 48 e 49 - Frente e verso do último folheto produzido pela campanha do Programa Viva Mulher no qual o câncer de mama já é retratado especificamente...... 148 Figura 50 - Interior do último folheto produzido pela campanha do Programa Viva Mulher no qual o câncer de mama já é retratado especificamente. 149

Figura 51 - Frente do Consenso para o Câncer de Mama, principal material que explicita a proposta do programa nacional de controle da doença... 150 Figura 52 - Frente do Consenso para o Câncer de Mama, principal material que explicita a proposta do programa nacional de controle da doença... 151 Figura 53 - Interior do Consenso para o Câncer de Mama, principal material que explicita a proposta do programa nacional de controle da doença. 152 Figura 54 - Verso do Consenso para o Câncer de Mama, principal material que explicita a proposta do programa nacional de controle da doença 153 


\section{Lista de Gráficos}

Gráfico 1 - Serviços Especializados de atendimento à mulher em situação de violência que receberam apoio da Secretaria Especial de Políticas para as Mulheres. 34 Gráfico 2 - Divisão de Ministérios e Secretarias dentro do Plano Nacional de Políticas para as Mulheres. 36

Gráfico 3 - Ações de Ministérios e Secretarias Especiais para o eixo “Autonomia, igualdade no mundo do trabalho e cidadania” do Plano Nacional de Políticas para as Mulheres 40

Gráfico 4 - Empoderamento feminino - Saúde e Bem-Estar. 41 Gráfico 5 - Ações de Ministérios e Secretarias Especiais para o eixo "Saúde das mulheres e direitos sexuais e reprodutivos” do Plano Nacional de Políticas para as Mulheres. 41

Gráfico 6 - Estimativas de câncer no Brasil no ano de 2008 55 Gráfico 7 - Proporção de mulheres com mais de 25 anos que nunca fizeram exames de

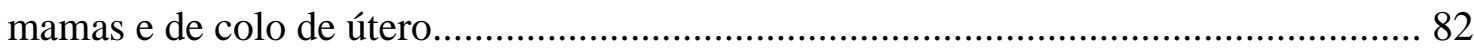

Gráfico 8 - Cobertura de plano de saúde por nível de renda......................................... 82 Gráficos 9 e 10 - Recall da campanha O Câncer de Mama no Alvo da Moda..............140 Gráfico 11 - Veículos mais lembrados da campanha O Câncer de Mama no Alvo da Moda...... .140

Gráfico 12 - Avaliação geral das entrevistadas sobre a campanha O Câncer de Mama no Alvo da Moda.

Gráfico 13 - Produção ambulatorial de exames de colo de útero no SUS de julho/1994 a março/2001. 


\section{Lista de tabelas}

Tabela 1 - Empoderamento feminino: avaliação das disparidades globais de

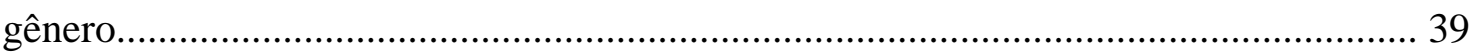

Tabela 2 - Estimativas, para o ano de 2008, de número de casos novos por câncer em homens e mulheres segundo localização primária....................................................... 54

Tabela 3 - Estimativas, para o ano de 2008, de número de casos novos por câncer em homens e mulheres segundo os Estados da República................................................... 56

Tabela 4 - Uma Avaliação da Integralidade na Atenção à Saúde das Mulheres no Brasil, 2005.

Tabela 5 - Capacidade instalada e produção de mamógrafos no SUS, por UF, no Brasil, 2005 80

Tabela 6 - Potencial de Produção de mamografias, número de mamógrafos e população

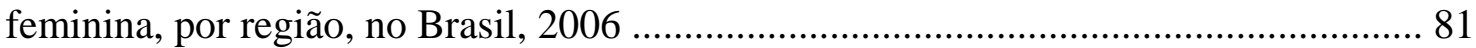

Tabela 7 - Divisão dos signos na semiótica peirceana..................................................91 


\section{Lista de siglas}

ANVISA - Agência Nacional de Vigilância Sanitária

CACON - Centros de Assistência de Alta Complexidade em Oncologia

CONAR - Conselho Nacional de Auto-Regulamentação Publicitária

COMPREV/INCA - Coordenação de Prevenção Vigilância do INCA

DATASUS - Banco de Dados do Sistema Único de Saúde

IBGE - Instituto Brasileiro de Geografia e Estatística

INCA - Instituto Nacional de Câncer

IBCC - Instituto Brasileiro de Controle do Câncer

MS - Ministério da Saúde do Brasil

OMS - Organização Mundial de Saúde

ONU - Organização das Nações Unidas

PAISM - Programa de Assistência Integral à Saúde da Mulher

PNAC - Política Nacional de Atenção Oncológica

SAS - Secretaria de Atenção à Saúde

SPM - Secretaria Especial de Políticas para as Mulheres

SUS - Sistema único de Saúde

WEF - World Economic Forum

RENAME - Relação Nacional de Medicamentos Essenciais

CACOM - Unidades de Assistência de Alta Complexidade em Oncologia 


\section{SUMÁRIO}

Introdução

16

Capítulo 1. Gênero no universo midiático

1.1. Mulheres e comunicação de massa......................................................................... 22

1.2. Meios de comunicação e eqüidade de gênero no Brasil........................................ 32

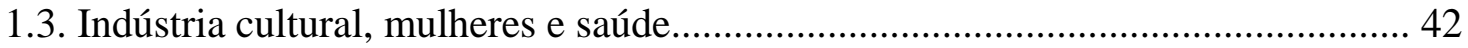

Capítulo 2. Câncer de mama no Brasil

2.1. Contextualização do câncer de mama..................................................................... 52

2.2. Mastectomia e linguagem do câncer..................................................................... 58

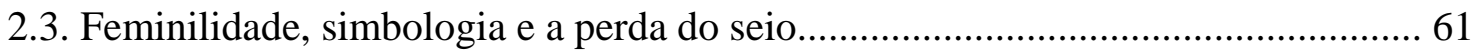

2.4. Políticas e direitos para o câncer de mama........................................................... 67

Capítulo 3. Semiótica e a campanha do IBCC

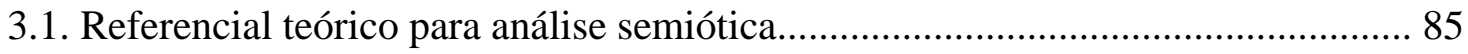

3.2. Semiótica da linguagem do câncer de mama........................................................ 91

3.3. Campanha - O câncer de Mama no Alvo da Moda................................................ 93

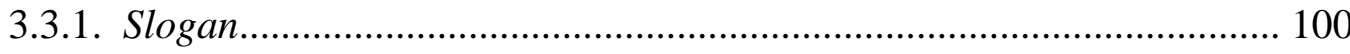

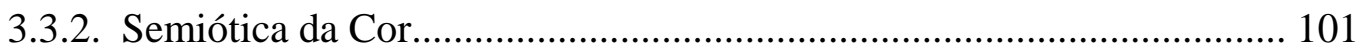

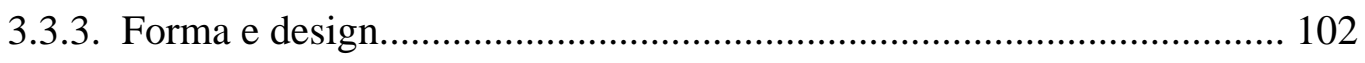

3.3.4. Tríade semiótica da marca.................................................................... 103

3.3.5. Considerações sobre a campanha......................................................... 104 
Capítulo 4. Comunicação pública de saúde e o Inca

4.1. Iniciativas governamentais sobre cânceres femininos......................................... 108

4.2. Primeiros folhetos de comunicação do Inca............................................................113

4.3. Viva Mulher - Programa Nacional de Controle do Câncer do Colo de Útero e de

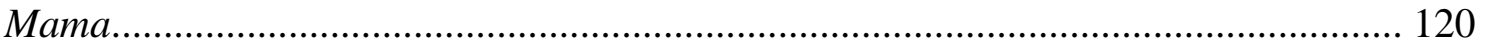

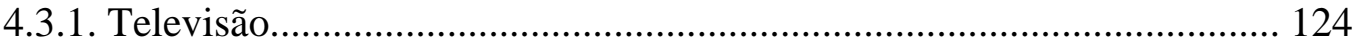

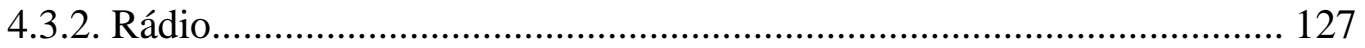

4.3.3. Cartazes e folhetos........................................................................... 132

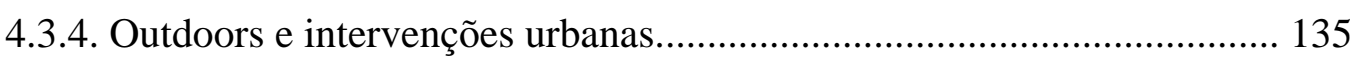

4.3.5. Propagandas de apoio...................................................................... 136

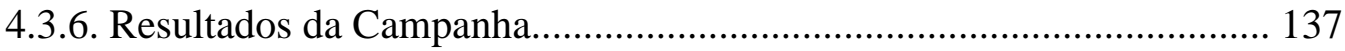

4.4. Incorporação do Câncer de Mama no Programa Viva Mulher................................142

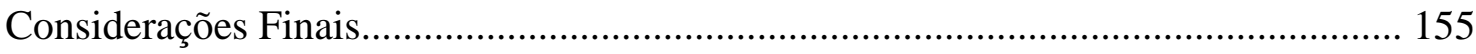

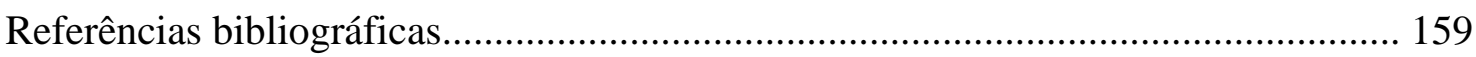

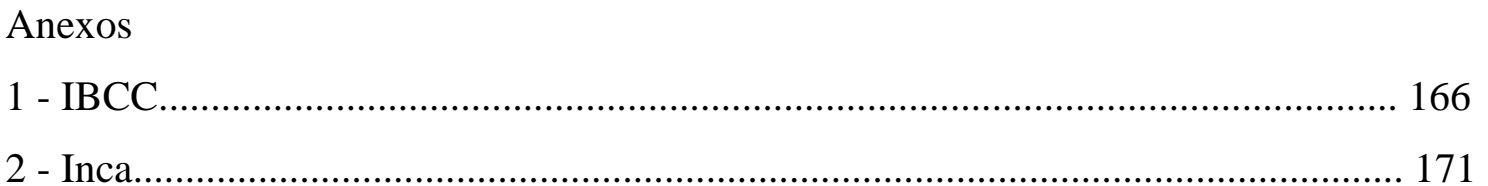




\section{Introdução}

A presente pesquisa destina-se a analisar as iniciativas de comunicação de controle da doença câncer de mama, verificando as suas ocorrências nas diferentes mídias existentes, bem como os discursos adotados no cenário da sociedade de massa, articulando tais assuntos às questões de gênero e saúde pública feminina.

Pretende-se verificar com a investigação qual é a contribuição das ações comunicativas às perspectivas de melhoria da condição social da mulher, destacando se as peças desenvolvidas mobilizam a sociedade para o assunto e quais os benefícios alcançados decorrentes desse acesso à informação.

A metodologia da pesquisa visa avaliar o conteúdo das divulgações de publicidade sobre a doença câncer de mama no cotidiano da mulher brasileira. Em primeiro lugar, serão realizadas análises das iniciativas governamentais do Instituto Nacional de Controle do Câncer - INCA, e em segundo, investigações referentes às práticas comunicacionais da campanha do Instituto Brasileiro de Controle do Câncer - IBCC.

Os objetivos pretendidos são descobrir se as ações publicitárias brasileiras do Inca e do IBCC contribuem com as políticas públicas de saúde feminina e se os efeitos das campanhas atingem a sociedade como um todo e influenciam na erradicação e prevenção da doença.

Por meio da junção da linha de pesquisa semiótica e de teóricos críticos da comunicação de massa espera-se averiguar o processo de emissão publicitária. Sendo assim, serão contrapostos os conceitos sociológicos da difusão das mensagens com a análise das peças destinadas à mulher, e para o embasamento da argumentação teórica, optou-se também pela adoção de autores ligados às áreas sociológicas do câncer de mama e às questões de gênero.

Para tal estudo, pretende-se realizar estudos bibliográficos em livros, revistas e artigos em geral, no Brasil e no exterior, sobre comunicação e saúde feminina. Fontes secundárias de informação em sites de interesse, tais como Ministério da Saúde do Brasil, DATASUS, IBCC, Inca, também contemplarão parte da busca para a pesquisa. Foram ainda realizadas entrevistas com profissionais de saúde dos institutos acima citados.

A linha de pesquisa adotada será a semiótica aplicada à comunicação com vistas à interpretação do processo de emissão das divulgações. Contudo, pretende-se referenciar 
também alguns teóricos da comunicação de massa, objetivando contrapor a funcionalidade dos veículos de comunicação com as mensagens que de fato atingem as mulheres.

No capítulo I, comenta-se sobre assuntos significativos das conquistas femininas, seus tabus e preconceitos enraizados na história da civilização humana e cujas premissas foram originárias do papel da mulher na sociedade. A partir da conceituação estética, a pesquisa visa ponderar sobre a saúde feminina, a imagem da mulher na mídia e a estratégia de consumo direcionada a esse público-alvo. Importa analisar como esse comércio de informações estabelece vínculos nos artefatos da sociedade de massa.

Nesta parte da bibliografia, foram escolhidas, entre outras, as obras de BEAUVOIR (1970 e 1975), pela reflexão histórica da situação feminina na sociedade e pela análise da condição da mulher no âmbito sexual, psicológico, social e político.

Durante a descrição da história feminina, o texto citará pesquisadores cujas obras retratam a relação de poder estabelecida entre os sexos. LIPOVETSKY (2000) será outro autor referente ao texto argumentativo sobre gênero e analogia de comando imposta à mulher, primeiramente, devido à conduta moral oriunda da valorização da família, e em seguida, ponderando sobre a contemporaneidade e a autoridade sofrida pela mulher, predominantemente relacionada à estética.

O autor assume que o desenvolvimento do individualismo feminino e a intensificação das pressões sociais das normas do corpo pertencem ao mesmo patamar ditatorial. De um lado, o corpo feminino se emancipou amplamente de suas antigas sujeições, fossem sexuais, procriadoras ou indumentárias. De outro, hoje, encontra-se reprimido a coibições estéticas mais imperativas, normativas e precursoras de ansiedade do que antigamente.

A partir da conceituação estética, a pesquisa visa ponderar sobre a saúde feminina e a imagem da mulher na mídia. Embora apareçam comumente nos veículos de comunicação, as divulgações sobre saúde são matérias que, em grande parte, direcionam-se ao consumo de cosméticos, tratamentos diversificados e terapias milagrosas. A abordagem sobre saúde da mulher, quando não é superficial, é mínima se comparada a outras tantas relacionadas a vendas.

Pode-se considerar que sobre o aparecimento do câncer de mama na mídia, as campanhas se caracterizam como pioneiras, cujos resultados tendem a desmistificar e desconstruir a imagem estigmatizada que antigamente conceituava a mulher como simples reprodutora, lembrando que há poucos anos atrás, as necessidades de consultas médicas femininas aconteciam somente em casos ligados à gestação e procriação. 
A finalidade da mídia e suas concepções histórico-sociológicas também serão incorporadas à pesquisa, como por exemplo, na utilização dos conceitos de ADORNO (1989) a respeito da teorização e elaboração do termo indústria cultural, escrito por ele e pesquisadores da Escola de Frankfurt, em 1947. Nessa etapa do projeto, implica estudar o quanto as imagens e narrativas oferecidas pelos veículos de comunicação fortalecem a proposta de operar sobre as cenas imaginárias do universo feminino.

Outra característica a ser ressaltada da "indústria cultural" na pesquisa é a estratificação dos públicos, cujas delimitações abrangem as diferentes faixas etárias e gênero dos indivíduos, como por exemplo, as categorias infantil, infanto-juvenil, juvenil, feminina, estudantil, entre outras. Esta linha de raciocínio será seguida com a finalidade de interpretar as mensagens publicitárias proporcionadas diariamente pela mídia, e até que ponto a popularização do assunto saúde é acessível às mulheres, considerando qual é papel do câncer de mama no contexto mercadológico da comunicação.

No final do capítulo I, o texto abordará a relação entre as peculiaridades da mensagem midiática para mulheres e como é idealizada a estratégia de consumo direcionada a esse público-alvo. Importa analisar como esse comércio de informações chega às pessoas, que tipo de produtos são oferecidos e como as diferentes classes econômicas femininas vivenciam essa realidade proposta nos artefatos da sociedade de massa.

No capítulo II, pretende-se abordar de maneira exploratória o contexto do câncer de mama no Brasil por meio da utilização de dados de incidência, mortalidade e erradicação da doença. Essa etapa da pesquisa enfatizará tabelas, gráficos, legislações, políticas e informações de órgãos públicos nacionais e internacionais, como O Programa de Cirurgia Plástica Reconstrutiva da Mama, a Política Nacional de Atenção Oncológica, a Relação Nacional de Medicamentos Essenciais, entre outros. Serão utilizados dados da OMS Organização Mundial de Saúde, Ministério da Saúde do Brasil, INCA - Instituto Nacional de Câncer, IBGE - Instituto Brasileiro de Geografia e Estatística, entre outros.

O texto também trará questões relativas à mastectomia - técnica cirúrgica que compreende a retirada integral da mama e do músculo peitoral -, incorporando os enfrentamentos psicológicos da feminilidade. Para descrever esse lado mais subjetivo do gênero e das conseqüências físicas e sociais da doença serão analisadas as considerações de ZECCHIN (2004). A pesquisadora utiliza-se da simbologia do seio para descrever a mastectomia como uma mutilação dos sentimentos e das experiências individuais do universo feminino. 
Por fim, serão acrescentadas ao capítulo as idéias de SONTAG (2002), romancista, ensaísta, feminista, que descreveu o caráter lingüístico das doenças, especificamente do câncer. Talvez pela própria vivência da escritora como portadora da doença, a obra destaca-se pela análise da retórica e da imagem do câncer em importantes fatos históricos da contemporaneidade.

O capítulo III trará a interpretação da campanha O câncer de mama no Alvo da Moda do Instituto Brasileiro de Controle do Câncer - IBCC. Para tais análises a linha de pesquisa adotada é a semiótica Peirceana, que tem sua base nos estudos de Charles Sanders Peirce (1839-1914), com referências ao seu conceito da tríade dos signos ${ }^{1}$. Os fundamentos e representações interpretativas serão estudados a fim de entender as noções de produção de significados, ou seja, da semiose publicitária.

Um dos pontos-chave dessa ciência dos signos é a capacidade de categorização dos seus diferentes enunciados e significados, pois sendo considerados signos as palavras, os sons, os símbolos, os índices, etc., com cadeias de representações infinitas, a semiótica se torna uma teoria básica para a compreensão da heterogeneidade nos processos de transmissão dos códigos humanos. Sendo assim, é possível compreender os códigos da comunicação como um todo e decifrar as ações de propaganda com um embasamento crítico referente à autoria das mensagens.

Nesta linha de pesquisa, serão adotadas as obras de SANTAELLA (2004 e 1998) e PEREZ (2004), por seus estudos críticos dos signos e por demonstrar de quais maneiras a semiótica Peirceana pode ser aplicada na publicidade e na comunicação como um todo.

A partir do estudo dos signos, surgem as três divisões básicas da semiótica em que as características das peças publicitárias ficam evidenciadas com mais clareza, e de certa maneira podem decifrar os objetivos finais da marca construída de uma campanha de controle do câncer de mama. Essa identidade marcária analisada semioticamente interfere na rotina social das mulheres, gerando interpretantes de educação e precaução e, em último caso, também pode gerar a criação de hábitos, como por exemplo, do auto-exame e exame clínico das mamas.

O signo câncer de mama detém alto poder simbólico há décadas; porém, devido ao crescimento da doença no século XXI, hoje, seus referenciais e interpretantes atingem maior grau de impacto comportamental. No contexto de caracterização das representações

\footnotetext{
${ }^{1}$ Segundo Peirce, diante de qualquer acontecimento, isto é, para conhecer e compreender qualquer coisa, a consciência produz um signo, ou seja, um pensamento como mediação irrecusável entre nós e os fenômenos.
} 
simbólicas e figurativas da linguagem contemporânea, as palavras relativas à doença são carregadas de fortes interpretações, como por exemplo, maligno ou benigno, células invasoras, entre outras.

A palavra câncer está carregada de significados da proliferação de qualquer malefício, sendo usada em diferentes contextos da linguagem da comunicação humana. Os objetos de estudo encontram-se nos jornais, em discursos políticos e na mídia em geral. $\mathrm{Na}$ área da publicidade, a tendência é notável, pois apesar de descrever de uma maneira bem mais sutil, prioriza o discurso do "combate" à doença.

Por fim, espera-se que se avaliem todas as peças de publicidade do câncer de mama referidas na pesquisa por meio da junção da análise semiótica com as teorias de comunicação de massa. A idealização consiste em discursar sobre a funcionalidade dos meios, neste caso voltados ao público feminino, e avaliar se o processo de emissão assume o caráter informativo e educativo sobre a doença.

No capítulo IV, serão analisadas as peças de atuação do Inca e as relações da saúde pública com o viés da comunicação, comentando sobre a premissa do caráter informativo e educativo da doença.

Pretende-se, nos dois últimos capítulos da pesquisa, decompor os elementos de identidade marcária das peças comunicativas sobre câncer de mama que, adotados no processo de emissão publicitária, tornam-se passíveis de interpretações analíticas.

Para esse trecho serão utilizadas as obras de IASBECK (2002) e FIORIN (1998) sobre a construção dos slogans, pois se acredita que o material lingüístico desses textos decifre e gere significados das relações de cultura, sintetizando pontualmente o objetivo da comunicação imediata. Já os signos cromáticos, as cores estabelecidas para as peças publicitárias, serão analisadas pelas obras de FARINA, PEREZ e BASTOS (2006) e HELLER (2005).

As hipóteses elaboradas apontam para um paradoxo entre divulgação massiva do assunto e o entendimento efetivo da doença, supondo-se que a condição social da mulher evoluiu em relação aos benefícios alcançados decorrentes do acesso à informação, embora tal comunicação não alcance patamares significativamente influentes na erradicação e prevenção da doença. 
Capítulo I

Gênero no universo midiático 
A relação ontológica do feminino e do masculino iniciou sua disparidade na pragmática degradação que o homem corroborou para si mesmo em toda a História ao apontar sempre manifestações decisivas e desveladas no modo de conceber o poder. Nestes séculos de civilização, ocorreu em certa medida o desenvolvimento social, a decisão, finalização e o recomeço de conflitos militares e as circulações de informações que fortaleceram a escalada das grandes descobertas. Porém, a eqüidade entre os gêneros está ainda em processo constitutivo.

É pelo exercício do trabalho que a mulher vem diminuindo a distância que a separava da igualdade com o homem. A independência concreta do universo feminino esteve ininterruptamente ligada às grandes lutas por igualdade de direitos e, principalmente, às conquistas do século XX, que foram a grande força de propulsão para o reconhecimento da mulher no campo profissional, familiar e na sociedade de um modo geral. Assim sendo, para entender as representações femininas faz-se necessário priorizar a exposição crítica de alguns fatos ligados à sua trajetória histórica.

A partir de uma leitura social do contexto das questões de gênero, pode-se concluir a incorporação de uma atribuição mercadológica, instituída e afirmada constantemente com relação ao produto corpo feminino na "indústria cultural", termo empregado pela primeira vez no livro Dialektik der Aufklãrung (Dialética do Iluminismo), escrito por Adorno e Horkheimer, pesquisadores da Escola de Frankfurt, em 1947.

Durante a Revolução Industrial no século XVIII, delineava-se previamente o conceito de Sociedade de Massa, uma migração ${ }^{2}$ da força de trabalho rural européia em direção às cidades que se encontravam sob dominante processo de industrialização. O desenvolvimento das técnicas no contexto histórico-sociológico corroborou a segmentação da escala de produção industrial, iniciando assim o processo de conversão da cultura em mercadoria.

\footnotetext{
2 Tais migrantes passaram a criar uma arte própria chamada popular, e ao mesmo tempo passaram a consumir em grande escala os produtos industriais considerados inferiores às criações da cultura e da arte de elite. Este processo foi denominado como cultura e arte de massa e, para se referir aos meios tecnológicos capazes de transmitir a mesma informação para um vasto público, cunhou-se a expressão "comunicação de massa".
} 
O entretenimento e os elementos da indústria cultural já existiam muito tempo antes dela. (...) A indústria cultural pode se ufanar de ter levado a cabo com energia e de ter erigido em princípio a transferência muitas vezes desajeitada da arte para a esfera do consumo, de ter despido a diversão de suas ingenuidades inoportunas e de ter aperfeiçoado o feitio das mercadorias. (ADORNO e HORKHEIMER. Dialética do esclarecimento, p. 126)

Conforme colocado neste ensaio, o consumidor migra da categoria de "sujeito" para a de "objeto" e, além da segmentação do trabalho, a "indústria cultural" partilha com setores empresariais a tendência à maximização do consumo, ou seja, oferece o maior número de atrativos, mas com uma linguagem acessível a uma grande gama de consumidores em um processo de constante sincretismo e homogeneização.

Outra característica ressaltada na indústria cultural é a estratificação dos públicos, cujas novas delimitações abrangem as diferentes faixas etárias e gênero dos indivíduos, como por exemplo, as categorias infantil, infanto-juvenil, juvenil, feminina, estudantil, entre outros.

No final do século XIX e início do XX, a América Latina passou por movimentos de modernização, tais como a imigração, expansão do capitalismo, difusão em massa da escola, transportes, imprensa, telecomunicações, industrialização, cujas conseqüências não foram democráticas a todas as sociedades estabelecidas. Nesse ínterim, a implantação da indústria cultural no continente também corroborou a prática do sistema dos meios.

No Brasil, a consolidação da sociedade de massa aconteceu durante o período urbanoindustrial, particularmente após a Segunda Guerra Mundial, em diferentes setores, acompanhada pelos fenômenos da urbanização e da transformação do sistema de estratificação social com a expansão das classes operárias e das classes médias, entre outros fatores. Dentro desse contexto foram redefinidos antigos meios, como o cinema, a imprensa, o rádio, e direcionados às tendências, como a televisão e o marketing.

Pensando na exposição midiática do público feminino, pode-se afirmar que os "meios" encontraram um mercado de investimento significativo e de capital altamente rentável, compondo assim basicamente dois grandes apelos vinculados à problemática do corpo feminino. Primeiro, a caracterização fetichista e mercadológica na qual a mulher se torna apenas uma imagem cuja finalidade é a apreensão e apreciação do público masculino; segundo, um círculo vicioso do consumo de produtos e serviços na incansável e interminável busca do corpo ideal ditado pelos padrões de beleza contemporâneos, no qual as formas são estereotipadas e a juventude é glorificada. 
A cultura de massa "acultura" as novas gerações à sociedade moderna. Reciprocamente, a juventude experimenta de modo mais intenso o apelo da modernidade e orienta a cultura de massa nesse sentido. (...) Assim a cultura de massa desagrega os valores gerontocráticos, acentua a desvalorização da velhice, da forma à promoção dos valores juvenis, assimila uma parte das experiências adolescentes. (...) Sociologicamente, ela contribui para o rejuvenescimento da sociedade. (MORIN, 2007, p.157)

Estudar as imagens e narrativas oferecidas pela indústria cultural fortalece a proposta de operar sobre as cenas imaginárias do feminino, considerando a mídia mais como uma fonte ativa de reprodução e renovação dos valores. Sendo assim, a narrativa da representação social da mulher nos meios de comunicação permanece intrinsecamente ligada ao seu contexto histórico-sociológico.

A mulher enfrenta tabus, preconceitos e ocupa um papel de desvalorização na sociedade há muito tempo. BEAUVOIR, em seu livro célebre, O Segundo Sexo, composto em dois volumes - Fatos e Mitos e A Experiência Vivida, analisa, entre outros pensadores, Friedrich Engels ${ }^{3}$ e sua obra A origem da família, da propriedade privada e do Estado.

A autora pondera sobre a afirmação de que a história feminina depende essencialmente da história das técnicas. Considera que na Idade da Pedra, quando a terra era comum a todos, as possibilidades agrícolas eram universalmente limitadas. As forças femininas estavam focadas no trabalho doméstico, visto essencialmente como produtivo, com a fabricação de vasilhames, tecelagem, jardinagem, desempenhando um papel importante na vida econômica e ocasionando duas classes distintas, porém com igualdade entre elas.

Com a descoberta do cobre, do estanho, do bronze e do ferro, com o aparecimento da charrua, a agricultura estende seus domínios. Um trabalho intensivo é usado para desbravar florestas, tornar os campos produtivos. O homem recorre, então, ao serviço de outros homens que reduz à escravidão. A propriedade privada aparece: senhor dos escravos e da terra, o homem torna-se também proprietário da mulher. Nisso consiste "a grande derrota histórica do sexo feminino". (BEAUVOIR, 1970, p. 74)

\footnotetext{
3 Friedrich Engels (1820-1895) foi um filósofo alemão que escreveu, entre outras obras, A Origem da Família, da Propriedade Privada e do Estado, na qual, por influência do marxismo, analisa o foco materialista do desenvolvimento da civilização, classificando os diferentes tipos de família como: família consanguínea; família punaluana; família pairing; e família monogâmica. O livro também prioriza explicar a passagem do matriarcalismo ao patriarcalismo, correlacionando-a ao começo da propriedade privada e, conseqüentemente, ao início do Estado.
} 
BEAUVOIR concorda com os argumentos de Engels, embora afirme que para conhecer a situação da mulher "é preciso ir além da teoria do materialismo histórico que só vê no homem e na mulher entidades econômicas”. Já ambos autores concordam com os aspectos da corrente que afirma a humanidade não como uma espécie animal, mas como uma realidade histórica na qual a sociedade humana não sofre passivamente a presença da Natureza; ela a refaz constantemente, tomando posse sobre ela. Essa retomada de posse não é uma operação interior e subjetiva, mas se efetiva objetivamente na práxis.

O racionalismo científico, além de não libertar a mulher da dominação masculina concebida por meio das técnicas e do desenvolvimento da agricultura, sedimentou os preconceitos. Os primeiros cientistas, como Platão (428 a.C - 347 a.C), consideravam a mulher sexualmente demoníaca, ou como Aristóteles (384 a.C - 322 a.C), julgavam-nas psicologicamente irresponsáveis, e até o médico grego Galeno (131 d.C - 200 d.C) afirmava que o sexo feminino era fisicamente imperfeito.

Assim, a mulher não poderia ser considerada apenas um organismo sexuado: entre os dados biológicos só têm importância os que assumem na ação, um valor concreto; a consciência que a mulher adquire de si mesma não é definida unicamente pela sexualidade. Ela reflete uma situação que depende da estrutura econômica da sociedade, estrutura que traduz o grau de evolução técnica a que chegou a humanidade. (BEAUVOIR, 1970, p.73)

Já sobre o psicanalista Sigmund Freud (1856-1939), médico neurologista e fundador da psicanálise, a crítica de Beauvoir faz-se ainda mais expressiva. A autora rejeita suas contribuições nas quais enxerga apenas valores misogenistas. "É porque é do ponto de vista dos homens - e é o que adotam os psicanalistas de ambos os sexos - consideram-se femininas as condutas de alienação, e viris aquelas em que o sujeito afirma sua transcendência." Corrobora-se, assim, a alusão da mulher passiva.

O mito é uma dessas armadilhas da falsa objetividade. Trata-se mais uma vez, de substituir a existência vivida e os livres julgamentos que ela reclama por um ídolo imoto. A uma relação autêntica com um existente autônomo, o mito da mulher substitui a contemplação imóvel de uma miragem. 
BEAUVOIR questiona a estrutura hierárquica e a naturalização das relações sociais que durante séculos sustentaram as desigualdades entre os sexos. Por ser existencialista ${ }^{4}$, a autora entende a liberdade como escolha incondicional que o indivíduo faz do seu ser e do seu mundo. Quando a mulher julga estar subordinada a forças externas mais poderosas do que a sua vontade, esse julgamento é uma decisão livre. Em outras palavras, o conformismo ou a resignação são decisões livres.

A autora não enxerga a mulher como um sexo frágil ou uma vítima do homem e de sua dominação, mas como uma vítima de si mesma, de sua passividade. Contemporaneamente, a realidade já se faz distinta; porém, em 1949, época na qual a autora escreveu tal obra, a ideologia pregada em seus textos era no mínimo revolucionária.

Olhos de reconstrução e transformação. A mulher necessita repensar sua colocação no mundo, bem como suas premissas de ser mãe, dona de si e de seus desejos, pois para a filósofa francesa, a categoria de segundo sexo é uma imposição. "A sociedade sempre foi masculina; o poder político sempre esteve nas mãos dos homens. 'A autoridade pública ou simplesmente social pertence sempre aos homens', afirma Lévi-Strauss sobre seu estudo sobre as sociedades primitivas".

Segundo sexo é uma denominação baseada na irreversível oposição humana em relação ao diferente. $\mathrm{O}$ homem apenas se enxerga ao pensar e avaliar o outro, ou seja, aprende o mundo sob o signo da dualidade.

Esclarece-se, ao contrário, se, segundo Hegel descobre-se na própria consciência uma hostilidade fundamental em relação a qualquer outra consciência; o sujeito só se põe em se opondo: ele pretende afirmar-se como essencial e fazer do outro o inessencial, o objeto. (1970: 12)

BEAUVOIR afirma: "São os homens que compõem os códigos", e pode-se considerar que são eles que escreveram grande parte da História ocidental também. Portanto, foi a partir de tais ordens de sistema que a mulher se encontrou restrita a alguns estereótipos. A mãe e a prostituta foram os mais comuns. Todavia, o feminismo reagiu contra essa negação da autonomia da existência do gênero, rejeitando a idéia do eterno e passivo "bom feminino", conseguindo assim novos traços de desenvolvimento. Hoje em dia, graças a tais conquistas, existe uma grande diversidade de representações de mulheres.

\footnotetext{
${ }^{4} \mathrm{O}$ existencialismo considera cada indivíduo como um ser único que é autor dos seus atos e do seu destino.
} 
Nas palavras de LIPOVETSKY (2000), também filósofo e francês, embora contemporâneo, em A terceira mulher - permanência e revolução do feminino, a revolução do feminino surge com a liberdade sexual conquistada pela mulher e por intermédio do trabalho, ou seja, a partir da época em que surgiram outras profissões e a sombra da prostituição deixou de ser crucial. $\mathrm{O}$ autor defende que o liberalismo cultural sustentado pela eficácia do consumo e da comunicação de massa autonomiza o sexo em relação à moral, generaliza o princípio de livre posse de si e desvaloriza, em partes, o esquema da subordinação entre os sexos.

\begin{abstract}
A revolução das necessidades, revolução sexual: a época do consumo de massa não se caracteriza apenas pela proliferação dos produtos, mas também pela profusão dos signos e referenciais do sexo. Os anos 50 são testemunhas de uma escalada erótica da publicidade; Eros $^{5}$ se exibe um pouco em toda a parte nos filmes e nas revistas, antes mesmo que a pílula e a irrupção das correntes contestadoras iniciem a revolução dos costumes dos anos 60-70. (...) À medida que a liberdade sexual deixou de ser um sinal de moralidade, a atividade profissional feminina se beneficiou de julgamentos muito mais amenos. (LIPOVETSKY, 2000, p. 229)
\end{abstract}

A primeira mulher é o estereótipo do indivíduo subordinado ao homem, confinada às "atividades sem brilho". A segunda é esclarecida, batalhadora, enaltecida e idolatrada pelas feministas; todavia, o autor não acredita mais na permanência dessas duas generalizações categóricas. Agora, a terceira mulher está inserida na lógica liberadora do individualismo contemporâneo e se encontra ainda presa aos valores sociais modernos, embora estes tenham reinventado e reorganizado suas velhas ideologias de sujeição feminina.

LIPOVESTSKY não faz jus à categorização numérica e comportamental de Beauvoir, na qual a mulher se encontra como o segundo sexo, subordinada ao sexo masculino. Porém, realiza uma avaliação dos papéis femininos na atualidade, expondo a não afirmação da mulher no papel de vítima dominada pelo macho, nem no desempenho de indivíduo combativo anunciado pelo feminismo histórico.

Para o desenvolvimento do progresso feminino, as instituições organizadas de mulheres tiveram um papel fundamental nos últimos séculos, sempre combativo, mas infelizmente pouco difundido. Nas palavras do autor, ocorreu uma significativa alternância de exigências. Nas décadas de 60 e 70, o feminismo se empenhava em emancipar a sexualidade das normas morais, em fazer regredir a influência do social sobre a vida privada. Hoje, ao contrário, a reivindicação é cada vez mais de controle público sobre a vida privada,

\footnotetext{
${ }^{5} \mathrm{Na}$ mitologia grega, Eros, filho de Afrodite, é o deus do amor.
} 
com leis sobre o assédio sexual, códigos de comportamento e linguagem corretos, proibições da pornografia, entre outros.

A conversão dessas cobranças deve-se ao poder de comercialização e fetichismo sucumbido ao corpo feminino e, conseqüentemente, aos seus estigmas atuais. Atualmente, o mercado está mais do que nunca voltado para a eterna busca da beleza, ocasionando assim uma incansável busca pela perfeição, na qual o ápice do consumo se torna inatingível, provocando constantes sentimentos depressivos estético-narcisistas, ou, como comenta LIPOVETSKY, a incansável reafirmação do belo sexo, ou a continuação da dominação masculina e da negação da mulher por novos meios.

\footnotetext{
Paradoxalmente, o desenvolvimento do individualismo feminino e a intensificação das pressões sociais das normas do corpo andam juntos. De um lado, o corpo feminino se emancipou amplamente de suas antigas servidões, sejam sexuais, sejam procriadoras ou indumentárias: do outro, ei-lo, submetido a coerções estéticas mais regulares, mais imperativas, mais geradoras de ansiedade do que antigamente. (2000, p. 135)
}

Implica ressaltar que durante a maior parte da História da humanidade, a mulher não representou de modo algum a encarnação suprema da beleza. Ao se descrever a Pré-história e as sociedades selvagens, pode-se concluir que a perfeição estética é um fenômeno social. Com base no autor, no período Paleolítico, as representações de mulheres eram mais signos femininos, como triângulos pubianos e estatuetas de mulheres nuas de seios flácidos e hipertrofiados e bacias grandes, símbolos de fertilidade. No Neolítico, já se notam traços mais humanos. As deusas-mães apresentam expressões de poder acima dos homens.

Porém, com o aparecimento do Estado e das classes sociais, o reconhecimento social da beleza feminina entrou em uma nova fase histórica, como no caso da Grécia Clássica (houve também nessa época os primeiros sinais da consagração e do culto à beleza masculina, manifestações mais direcionadas aos âmbitos do poder, dos esportes e da guerra). São exemplos as deusas do Panteão: Hera, Ártemis, Atena e Afrodite, e também as representações de Pandora, constantemente ligada a uma parte maléfica das mulheres, e Helena, cuja beleza serviu de pretexto à guerra de Tróia. 


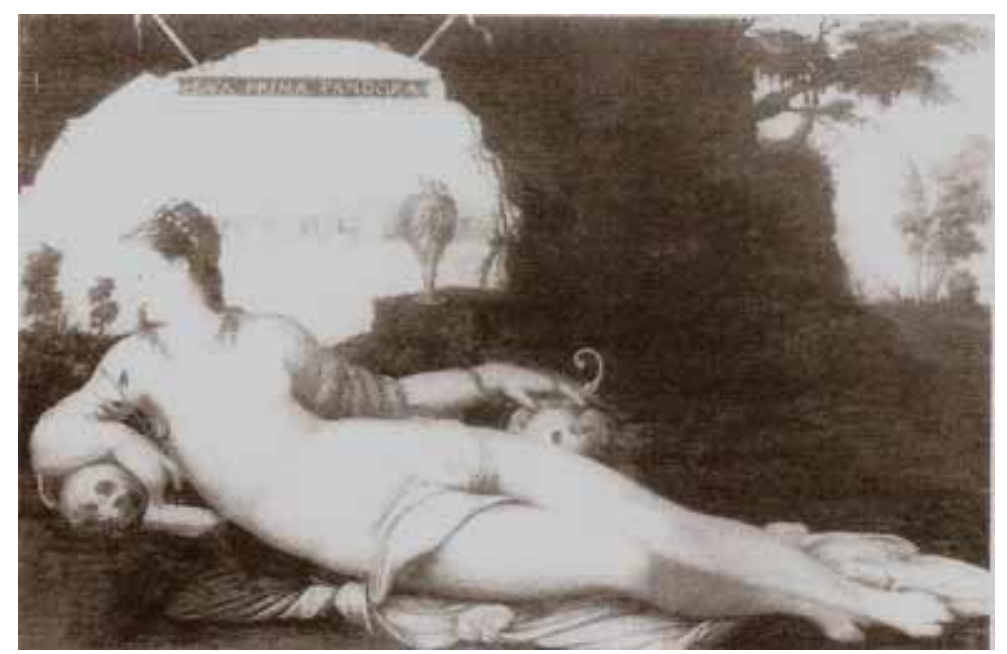

Figura 1 - Eva Prima Pandora, de Jean Cousin. França, século XVI

Fonte: Yalom, História do Seio, 1997

Apesar de beleza não ser um conceito recente, enxerga-se hoje um acréscimo no seu ambiente de manifestação cultural e social. O mito do corpo transpôs novos valores para a sociedade mais democrática, tecnológica e globalizada, renunciando assim a sua subordinação ao destino. Há algum tempo, a beleza estética composta por padrões harmoniosos era considerada uma dádiva. Alguns nasciam belos; aos demais restava a resignação. Agora, o universo delineou-se variavelmente. A virtude do homem é a falta de acomodação, ou seja, é possível sempre recuperar os juros biológicos e realizar uma dieta rigorosa, uma cirurgia plástica e, assim, ficar mais bonito. Basta lutar e/ou pagar.

O belo continua a ser uma característica mais feminina do que masculina, oriunda da Renascença, quando a perfeição era sagrada; e para resguardá-la, a mulher se encontrava condenada a um papel limitado e doméstico. O movimento feminista e a sociedade de consumo alteraram esse contexto, mas a mulher não deixou de ter uma identificação fortemente ligada à estética.

Para LIPOVETSKY, as mulheres, por imposições culturais, desvalorizam a imagem que fazem de si, desviando-a do combate social e da vida política. Contentam-se com empregos subalternos, aceitam salários inferiores aos dos homens, são pouco sindicalizadas, respeitam mais os homens do que a si mesmas, embora na modernidade, apesar de existirem algumas poucas permutabilidades dos papéis do sexo, haja a constituição de distâncias diferenciais mais tênues, menos anuladoras, não diretivas e com princípios de livre disposição de si. 
A mídia seguiu uma tendência pouco contestadora no que tange aos assuntos femininos e, segundo BOSI (2000), tal situação se deve ao fato de os veículos de comunicação assumirem posições avessas às polêmicas sociológicas. "A despolitização tem origem no desejo de agradar o maior número possível de leitores. Como a religião, a política é algo que divide." Porém, por outro lado, a autora defende o conceito de "democratização da informação" advindo do poder midiático. Até meados do século XIX, o significado de "cultura", algo acessível apenas à nobreza e à alta burguesia, não tinha mais vigência na medida em que os meios informativos passaram por um processo de generalização.

Há cada vez mais largas faixas de comunicação não acadêmica, comuns a várias classes sociais: a ação do rádio, da TV, do cinema, dos jornais, das revistas, dos livros de bolso é de tal sorte que, em termos quantitativos, se pode aproximar (e, não raro, identificar) os meios de comunicação e os meios de cultura, sobretudo nas nações mais desenvolvidas. (BOSI, 2000, p. 32)

Outro foco relevante sobre mídia e gênero aparece em MATTELART; sua tese decorre sobre o fato da mulher ser um dos alvos prediletos da cultura de massa e, mediante uma nova ordem simbólica, o feminino é obrigado a cumprir dois papéis: primeiro, o de pacificadora e sujeito ao qual cabe resolver certas contradições do sistema, como a família e a educação; segundo, o papel de pilar da "economia de apoio", colaborando com a força de trabalho desvalorizada e não remunerada, assegurando uma alta taxa de mais-valia ${ }^{6}$ ao salário do marido e, indiretamente, da mulher também. Ao decorrer de sua argumentação, a autora comenta sobre o papel materno nesse contexto com suas novas manifestações de prazer e labor.

\footnotetext{
Este tipo de familia, que su vez está em crisis, cuya identidad ha estallado en una suma de conciencias individuales, aisladas, dirigidas hacia si mismas, narcisistas, ofrece a la industria de los ócios um objetivo múltiple. Las nuevas formas de control social unidas a la aparición de la "cultura del narcisismo" se incriben em um contexto sócio-psicológico caracterizado por la sensación de la degradacion del trabajo y la búsqueda de la satisfacion em terreno de la vida privada, espacio del ócio. Así se situa la gran propaganda publicitaria cuyo objetivo es proyectar unas imagenes de satisfaciones totales e inmediatas que vayan asociadas al consumo de los bienes, de los servicios y de las experiencias. (MATTELART, 1982, p.113)
}

\footnotetext{
${ }^{6}$ Mais-valia é o termo criado por Karl Marx para a diferença entre o valor produzido pelo trabalho e o salário pago ao trabalhador, que justificaria a fundamentação da exploração no sistema capitalista.
} 
A mídia detém grande poder de influência sobre a criação, manutenção e difusão de modelos comportamentais, uma ferramenta importante na disseminação de questões relevantes à sociedade. Deve-se levar em consideração que a televisão possui papel preponderante nesse modelo de sociedade marcada pelos investimentos econômicos. Por ser o veículo de comunicação mais persuasivo e com alto poder sinestésico e metafórico em todas as classes sociais, a TV é um meio de comunicação que está presente no cotidiano social; tem um caráter apelativo marcante seduzindo e interferindo diretamente nos valores culturais.

Já a cultura representa um meio particular de integrar sociedades e povos dentro de aspectos universais distintos, podendo ser entendida como a totalidade daquilo que foi elaborado e repassado pela atividade humana na construção de um mundo coletivo e na identificação de um determinado grupo. Nesse aspecto, a sociedade de informação traduz as manifestações culturais em constantes estratégias mercadológicas; assim sendo, a informação provoca no contexto social mudanças de interesses de consumo.

A novidade se torna imperativo na modernidade, e neste panorama, a mulher tornou-se um alvo para o mercado, ansiando por inovação para resolver características naturais do seu corpo por meio de instrumentos que promovam o desejo da beleza, como a moda, os cosméticos, os serviços de estética, a alimentação, entre outros. Esse ciclo apoiado na publicidade adentra a sociedade e resulta na renovação das necessidades.

Grande parte do público feminino tem acesso ao mercado de produtos e bens de consumo, incentivando assim as corporações que alimentam a continuidade da indústria cultural a investirem em novos produtos de acordo com os estratos sociais, ao mesmo tempo em que produzem similares com qualidades distintas. Pode-se verificar uma democratização do acesso ao consumo por intermédio da massificação dos produtos oferecidos na lógica mercadológica. A sociedade de consumo legitimou o ideal de viver melhor, e a propaganda baseada no desejo de melhorar de vida é praticamente universal. Neste momento, implica diagnosticar as diferenças entre as melhorias necessárias no contexto do empoderamento feminino e as iniciativas estabelecidas da área de comunicação. 
1.2 - Meios de comunicação e eqüidade de gênero no Brasil

No Brasil, o órgão formado e mantido pelas agências de publicidade, empresas anunciantes e veículos de comunicação, o Conselho Nacional de Auto-Regulamentação Publicitária - CONAR, não aborda diretamente o assunto relacionado aos estigmas femininos e suas especificidades. A organização, apesar de não ser reconhecida como instituição social, é a única fiscalizadora da ética na propaganda comercial veiculada no país, norteada pelas disposições contidas no Código Brasileiro de Auto-Regulamentação Publicitária, documento este que se apóia em legislações e diretrizes datadas das décadas de 1950 a 19707 . Cabe ressaltar que no Brasil, ainda há legislação específica sobre a publicidade e a propaganda; o CONAR é apenas uma auto-regulamentação fundamentada em normas.

Tal ausência de leis específicas contra a deturpação da imagem feminina decorre de um processo nacional negligente com os assuntos de igualdade de gênero desde o tempo Brasil-colônia e que perpetua até hoje. Pouco se comenta das iniqüidades ocorridas nos campos históricos, profissionais e políticos com as mulheres brasileiras. Talvez a isto se deva a frase divulgada por Beauvoir no final da década de 40: "Toda a história das mulheres foi escrita pelos homens". E, portanto, acrescentou Teles ${ }^{8}$ (1993), "está sob suspeição".

Para tal questão obscurantista da história feminina Beauvoir completa:

Cumpre observar que em Paris, sobre cerca de mil estátuas (exceptuando-se as rainhas que por razões de ordem puramente arquitetural cercam o Luxemburgo) somente dez foram erguidas a mulheres. Três são consagradas a Joana d'Arc. As demais são de Mme de Segur, George Sand, Sarah Bernhardt, Mme Boucicault e a Baronesa de Hirsh, Maria Deraismes, Rosa Bonheur. (1970: p.170)

A autora ainda ressalta: "A proporção de Rainhas que realizaram grandes governos é infinitivamente superior a dos grandes reis. Isabel, a católica, Isabel da Inglaterra, Catarina da Rússia. O mesmo acontece com as santas".

\footnotetext{
${ }^{7}$ Código Brasileiro de Auto-Regulamentação Publicitária. Disponível em: www.conar.org.br. Acesso em: 24 jul. 2007.

${ }^{8}$ Maria Amélia de Almeida Teles é ativista dos movimentos feministas e de direitos humanos desde os anos 1970. Foi vítima de tortura quando esteve presa por motivos políticos em São Paulo (1972/1973), à época, grávida de sete meses, cujo filho nasceu na prisão. Pertenceu à equipe do Jornal Brasil Mulher e à coordenação dos três Congressos Paulistas de Mulheres. Fez parte do Comitê Brasileiro pela Anistia. Trabalhou no Conselho Estadual da Condição Feminina. Fez parte da Assessoria da Comissão de Direitos Humanos da Câmara Municipal de São Paulo. Atualmente, faz parte da Comissão Especial da Lei 10.726/2001, que visa a indenizar os ex-presos políticos torturados.
} 
Porém, voltando ao entendimento da questão sexista nacional, TELES destacou inúmeras mulheres que morreram defendendo suas terras, famílias e direitos, ou mesmo as que lutaram à época da ditadura militar brasileira, e complementa: "Mesmo as mulheres que foram protagonistas de movimentos sociais, como as de lutas pela reforma agrária, direito à moradia, incorporação das trabalhadoras rurais e domésticas à legislação trabalhista, não têm tido condições para escrever sua própria história".

Todavia, em sua obra, é possível conhecer grande parte das brasileiras memoráveis historicamente, desde as negras fugitivas e formadoras de núcleos de resistência no Período Colonial, as representantes dos embates na Primeira e na Segunda República até as ativistas na periferia dos centros urbanos nacionais, como por exemplo, as mulheres das organizações de luta por creche, além de sindicalistas, jornalistas, escritoras, artistas, entre outras.

Hoje, apesar dos avanços nas políticas públicas de gênero no país, ainda persistem dados vergonhosos sobre a violência contra mulheres. Dados da Fundação Perseu Abramo, realizados pelo Núcleo de Opinião Pública, embora respectivos ao ano 2001, demonstram o quanto o assunto violência necessita de transformações. Por meio de um estudo sobre o universo feminino, o Núcleo indicou que pelo menos 6,8 milhões, dentre as brasileiras vivas, já foram espancadas ao menos uma vez na vida. Considerando-se que 31\% declararam ter passado pela última ocorrência no período dos 12 meses anteriores à pesquisa, o que são cerca de 2,1 milhões de agressões nesse ano no país, $175 \mathrm{mil} / \mathrm{mês,} \mathrm{5.800/dia,} \mathrm{243/hora} \mathrm{ou} \mathrm{quatro} \mathrm{por}$ minuto, ou seja, já no início do século XXI, uma mulher era agredida a cada 15 segundos no Brasil. ${ }^{9}$

Segundo a Organização das Nações Unidas, a violência contra a mulher na família representa a principal causa de lesões em mulheres entre 15 e 44 anos no mundo, e implica 14, 6\% do Produto Interno Bruto (PIB) da América Latina, cerca de 170 milhões. No Brasil, a violência doméstica custa ao país $10,5 \%$ do seu PIB.

Atualmente, nota-se um maior número de iniciativas governamentais para tal problemática, como o Programa de Assistência Integral à Saúde da Mulher - PAISM e a Secretaria Especial de Políticas para as Mulheres, que estabelecem ações para a melhoria de vida das brasileiras. Porém, as atuações não são homogêneas e ainda há significativa discordância entre as regiões do país. ${ }^{10}$

\footnotetext{
${ }^{9}$ Portal da Fundação Perseu Abramo - http://www2.fpa.org.br/portal/modules/news/article.php?storyid=700

${ }^{10} \mathrm{http}: / /$ www.presidencia.gov.br/estrutura_presidencia/sepm/publicacoes/
} 

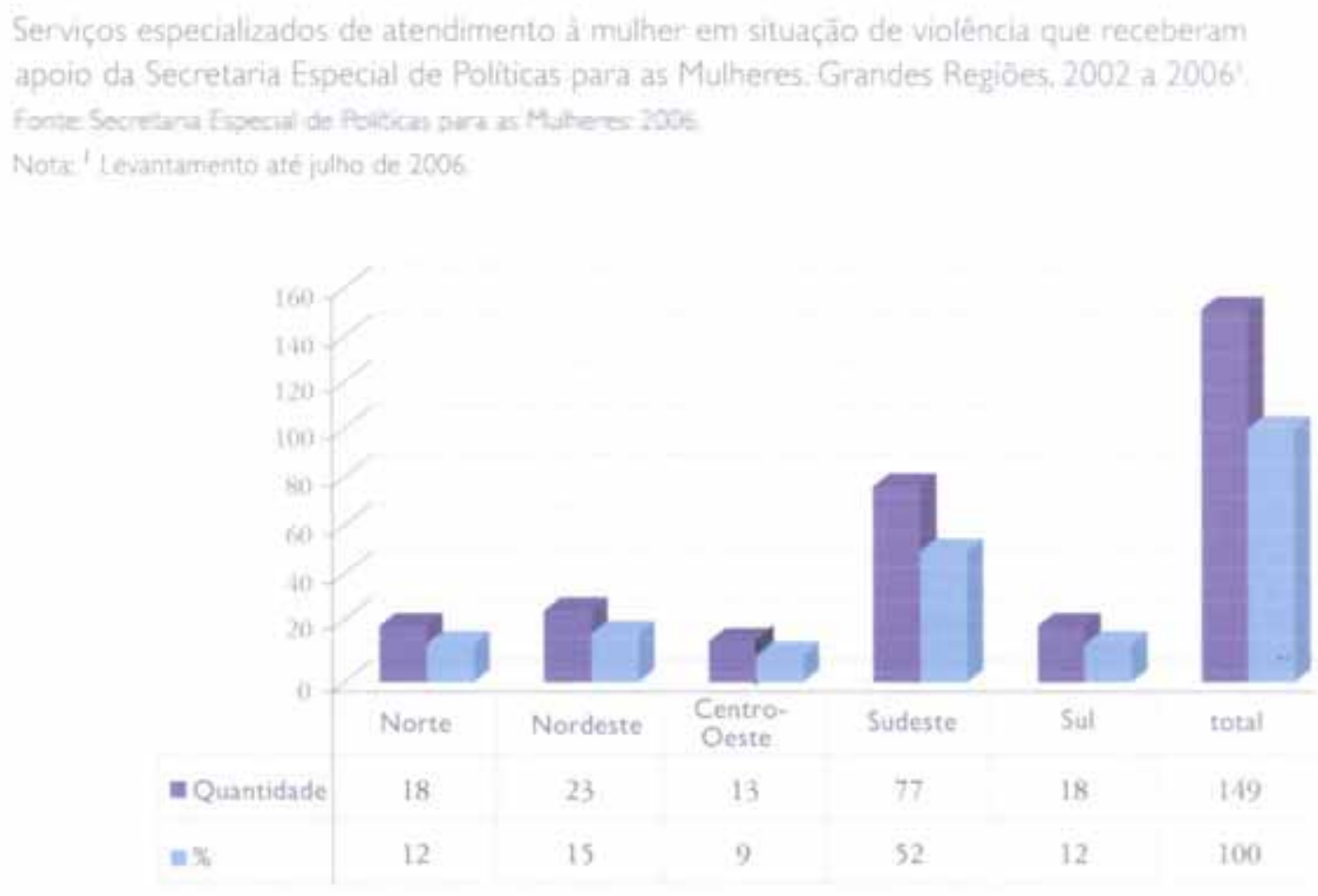

Gráfico 1 - Serviços Especializados de atendimento à mulher em situação de violência que receberam apoio da Secretaria Especial de Políticas para as Mulheres - Fonte: Secretaria Especial de Políticas para as Mulheres, 2006

Outra medida em voga sobre a coibição da violência doméstica e familiar contra a mulher é a Lei Maria da Penha ${ }^{11}$, vigente desde setembro de 2006, nos termos da Constituição Federal, da Convenção sobre a Eliminação de Todas as Formas de Discriminação contra as Mulheres e da Convenção Interamericana para Prevenir, Punir e Erradicar a Violência contra a Mulher. Segundo a lei ${ }^{12}$, são formas de violência doméstica e familiar contra a mulher, entre outras:

\footnotetext{
${ }^{11}$ A biofarmacêutica Maria da Penha Maia lutou durante 20 anos para condenar seu agressor e virou símbolo contra a violência doméstica. Em 1983, seu marido, o professor universitário Marco Antonio Herredia, tentou matá-la duas vezes. Na primeira vez, deu um tiro, deixando-a paraplégica. Na segunda, tentou eletrocutá-la. Na ocasião, ela tinha 38 anos e três filhas, entre 6 e 2 anos de idade. A investigação começou em junho do mesmo ano, mas a denúncia só foi apresentada ao Ministério Público Estadual em setembro de 1984. Oito anos depois, Herredia foi condenado a oito anos de prisão, mas usou de recursos jurídicos para protelar o cumprimento da pena. O caso chegou à Comissão Interamericana dos Direitos Humanos da Organização dos Estados Americanos (OEA), que acatou, pela primeira vez, a denúncia de um crime de violência doméstica.

${ }^{12}$ http://www.planalto.gov.br/CCIVIL/_Ato2004-2006/2006/Lei/L11340.htm
} 
I - a violência física, entendida como qualquer conduta que ofenda sua integridade ou saúde corporal;

II - a violência psicológica, entendida como qualquer conduta que lhe cause dano emocional e diminuição da auto-estima ou que lhe prejudique e perturbe o pleno desenvolvimento ou que vise degradar ou controlar suas ações, comportamentos, crenças e decisões, mediante ameaça, constrangimento, humilhação, manipulação, isolamento, vigilância constante, perseguição contumaz, insulto, chantagem, ridicularização, exploração e limitação do direito de ir e vir ou qualquer outro meio que lhe cause prejuízo à saúde psicológica e à autodeterminação;

III - a violência sexual, entendida como qualquer conduta que a constranja a presenciar, a manter ou a participar de relação sexual não desejada, mediante intimidação, ameaça, coação ou uso da força; que a induza a comercializar ou a utilizar, de qualquer modo, a sua sexualidade, que a impeça de usar qualquer método contraceptivo ou que a force ao matrimônio, à gravidez, ao aborto ou à prostituição, mediante coação, chantagem, suborno ou manipulação; ou que limite ou anule o exercício de seus direitos sexuais e reprodutivos;

IV - a violência patrimonial, entendida como qualquer conduta que configure retenção, subtração, destruição parcial ou total de seus objetos, instrumentos de trabalho, documentos pessoais, bens, valores e direitos ou recursos econômicos, incluindo os destinados a satisfazer suas necessidades;

V - a violência moral, entendida como qualquer conduta que configure calúnia, difamação ou injúria.

Porém, não é apenas a violência um fator impeditivo à igualdade de gênero no Brasil. Conforme dados divulgados pela Secretaria Especial de Políticas para as Mulheres ${ }^{13}$, entre os anos de 2003 e 2006, houve uma união de todos os ministérios e órgãos governamentais com a finalidade de atender às reivindicações de incorporação das especificidades das mulheres nas gestões públicas e no estabelecimento das condições necessárias para a sua plena cidadania.

No Gráfico 2, as legendas correspondem aos organismos do Plano Nacional de Políticas para as Mulheres, sendo MCid - Ministério das Cidades, Minc - Ministério da Cultura, MPOG - Ministério do Planejamento, Orçamento e Gestão, SEDH - Secretaria Especial dos Direitos Humanos, MDA - Ministério do Desenvolvimento Agrário, MJ Ministério da Justiça, MS - Ministério da Saúde, SEPIR - Secretaria Especial para Políticas de Promoção da Igualdade Racial, MDS - Ministério do Desenvolvimento Social e Combate à fome, MMA - Ministério do Meio Ambiente, MTE - Ministério do Trabalho e Emprego, SPM - Secretaria Especial de Políticas para Mulheres, MEC - Ministério da Educação, MME - Ministério de Minas e Energia e SEAP - Secretaria Especial Aqüicultura e Pesca.

\footnotetext{
${ }^{13}$ A Secretaria foi criada através da Medida Provisória 103, no primeiro dia do governo do presidente Luiz Inácio Lula da Silva, para desenvolver ações conjuntas com todos os Ministérios e Secretarias Especiais.

Fonte: http://www.presidencia.gov.br/estrutura_presidencia/sepm/
} 

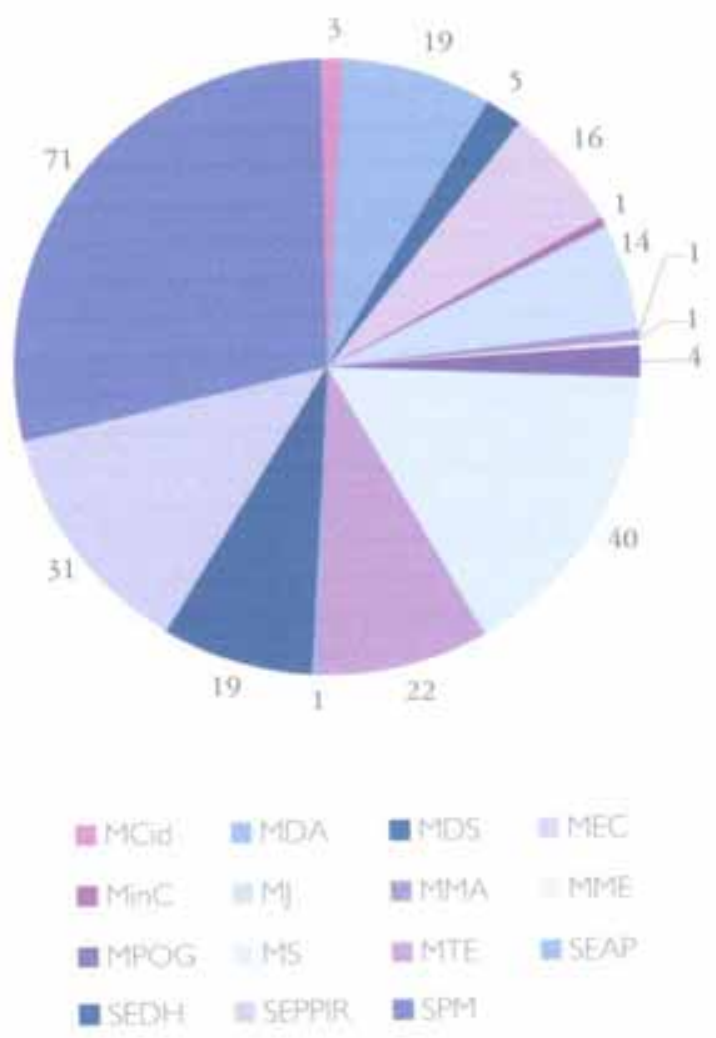

Gráfico 2 - Divisão de Ministérios e Secretarias dentro do Plano Nacional de Políticas para as Mulheres Fonte: Secretaria Especial de Políticas para as Mulheres, 2006

Os avanços conquistados pelo Brasil em relação às questões de gênero são derivados de marcos históricos influenciados pelos contextos sociais de determinadas épocas junto ao esforço de inúmeras mulheres, como por exemplo, acesso aos esportes (1924), o direito de estudar (1827), o ingresso nas universidades (1875) e o voto feminino no Brasil ${ }^{14}$ (1932).

Entre as mulheres mais influentes na História nacional destacam-se algumas personalidades, como a bióloga Bertha Lutz (1894 - 1976), que ao se aproximar dos movimentos feministas da Europa e dos Estados Unidos da América, criou as bases do feminismo no Brasil. Foi fundadora da Federação Brasileira para o Progresso Feminino em 1922, e eleita suplente para deputado federal em 1934. Suas principais bandeiras de lutam

\footnotetext{
${ }^{14}$ Antes, o voto feminino era permitido somente às mulheres casadas e às viúvas e solteiras que tivessem renda própria. Em 1934, tais restrições foram eliminadas do Código Eleitoral, embora a obrigatoriedade do voto fosse um dever masculino. Já em 1946, a obrigatoriedade do voto foi estendida às mulheres.
} 
eram mudanças na legislação trabalhista com relação ao trabalho feminino (igualdade salarial) e infantil. Outro importante nome foi o de Carlota Pereira de Queiroz (1892 - 1982): médica, pedagoga e política, fundou a Academia Brasileira de Mulheres Médicas em 1950, e tornou-se a primeira deputada federal da História do Brasil eleita pelo Estado de São Paulo em 1934. Além de Patrícia Rehder Galvão, conhecida pelo pseudônimo de Pagu (1910 - 1962), escritora, jornalista, militante comunista, presa e torturada diversas vezes no decorrer de sua vida. Em 1950, concorreu a deputada estadual em São Paulo pelo Partido Socialista Brasileiro, mas não foi eleita.

Hoje, graças a essas e outras inúmeras mulheres existem leis, programas, conselhos, institutos e diversos organismos voltados para a promoção da igualdade de gênero. Além das organizações globais, como as Conferências Mundiais sobre Mulheres, nas quais instituições reivindicam e verificam as medidas de combate às disparidades sociais entre homens e mulheres - como foi o caso da influência internacional no Brasil a respeito do caso de Maria da Penha.

Faz-se importante elencar algumas datas mundialmente reconhecidas sobre as lutas femininas:

- 8 de março - Dia Internacional da Mulher: a data foi eleita como uma homenagem a 129 mulheres queimadas vivas em uma fábrica de tecelagem em Nova Iorque, EUA, em 1857, por reivindicarem um salário justo e a redução da jornada de trabalho. À época as operárias confeccionavam um tecido lilás, posteriormente a cor tornou-se referência na luta feminina.

- 30 de abril - Dia Nacional da Mulher ${ }^{15}$.

- 18 de maio - Dia Nacional de Combate ao Abuso e à Exploração Sexual de Crianças e Adolescentes; a data escolhida é a da morte de Araceli, menina de oito anos, violentada e morta de forma hedionda, no Estado do Espírito Santo. Apesar de identificados, os culpados por sua morte nunca foram punidos.

- 28 de maio - Dia Internacional de Luta pela Saúde da Mulher e Dia Nacional de Redução da Morte Materna.

- 25 de julho - Dia Internacional da Mulher Negra Latino-americana e Caribenha.

\footnotetext{
${ }^{15}$ No decorrer da ditadura militar no Brasil, 1964-1984, foi proibida a comemoração do Dia Internacional da Mulher, 8 de março, e instituiu-se 30 de abril como o Dia Nacional da Mulher.
} 
- 23 de setembro - Dia Internacional contra a Exploração Sexual e o Tráfico de Mulheres e Crianças.

- 28 de setembro - Dia pela Discriminação do Aborto na América e Caribe.

- 10 de outubro - Dia Nacional de Luta contra a Violência à Mulher.

- 25 de outubro - Dia Internacional contra a Exploração da Mulher.

- 25 de novembro - Dia Internacional da Não-violência contra as Mulheres.

Apesar das conquistas, o Brasil ainda possui uma baixa classificação geral no que diz respeito às questões femininas segundo estudo realizado pelo World Economic Forum WEF, em 2005. O país ocupa o posto de $51^{\circ}$ na tabela de empoderamento das mulheres: avaliação das disparidades globais de gênero, na qual a relação dos níveis de desenvolvimento da igualdade entre os sexos está representada pelo número um, sendo este o nível mais baixo, e sete, como máxima eqüidade de gênero (vide Tabela 1). Porém, em comparação com os índices divulgados pela Secretaria Especial de Políticas para as Mulheres entre os anos de 2003 e 2006 (vide Gráfico 3), é notável a desconexão entre os dados de investimentos e incentivos públicos e os apontamentos realizados nos dois quadros apresentados. 


\begin{tabular}{|c|c|c|c|c|c|c|c|}
\hline Pula & $\begin{array}{l}\text { Clazs: } \\
\text { feagdo } \\
\text { geral }\end{array}$ & $\begin{array}{c}\text { Pontuacha } \\
\text { osmin }\end{array}$ & 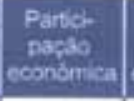 & $\begin{array}{l}\text { Oponts: } \\
\text { indate } \\
\text { econtonica }\end{array}$ & $\begin{array}{l}\text { Eniposes: } \\
\text { ramente } \\
\text { politico }\end{array}$ & $\begin{array}{l}\text { Avaneos } \\
\text { coticte } \\
\text { conais: }\end{array}$ & $\begin{array}{l}\text { Siche } \\
\text { bem: } \\
\text { entar }\end{array}$ \\
\hline Suécia & 1 & 5,53 & 5 & 12 & 8 & 1 & 1 \\
\hline Norvega & 2 & 5,39 & 13 & 2 & 3 & 6 & 9 \\
\hline Islândia & 3 & 5,32 & 17 & 7 & 2 & 7 & 6 \\
\hline Dinamarca & 4 & 5,27 & 6 & 1 & 20 & 5 & 2 \\
\hline Finlândia & 5 & 5,19 & 12 & 17 & 4 & 10 & 4 \\
\hline Nova Zelândia & 6 & 4,89 & 16 & 47 & 1 & 11 & 26 \\
\hline Canadá & 7 & 4,87 & 7 & 27 & 11 & 12 & 14 \\
\hline Reino Unido & 8 & 4,75 & 21 & 41 & 5 & 4 & 28 \\
\hline Alemanta & 9 & 4,61 & 20 & 28 & 6 & 34 & 10 \\
\hline Australia & 10 & 4,61 & 15 & 25 & 22 & 17 & 18 \\
\hline Letônia & 11 & 4,60 & 4 & 6 & 10 & 24 & 48 \\
\hline Lituấnia & 12 & 4.58 & 10 & 11 & 13 & 19 & 44 \\
\hline França & 13 & 4,49 & 31 & 9 & 14 & 31 & 17 \\
\hline Holanda & 14 & 4,48 & 32 & 16 & 7 & 42 & 8 \\
\hline Estōnia & 15 & 4.47 & 8 & 5 & 30 & 18 & 46 \\
\hline Irlanda & 16 & 4,40 & 37 & 51 & 12 & 9 & 12 \\
\hline Estados Unidos & 17 & 4,40 & 19 & 46 & 19 & 8 & 42 \\
\hline Costa Rica & 18 & 4,36 & 49 & 30 & 9 & 14 & 30 \\
\hline Polônia & 19 & 4.36 & 25 & 19 & 18 & 20 & 38 \\
\hline Belgica & 20 & 4,30 & 35 & 37 & 25 & 15 & 16 \\
\hline República Eslovaca & 21 & 4,28 & 14 & 33 & 29 & 23 & 35 \\
\hline Eslovênia & 22 & 4.25 & 26 & 15 & 39 & 22 & 19 \\
\hline Portugat & 23 & 4,21 & 27 & 18 & 31 & 36 & 20 \\
\hline Hungria & 24 & 4,19 & 30 & 3 & 28 & 39 & 40 \\
\hline República Checa & 25 & 4,19 & 24 & 4 & 43 & 25 & 23 \\
\hline Luxemburgo & 26 & 4,15 & 48 & 8 & 33 & 21 & 25 \\
\hline Espanha & 27 & 4,13 & 45 & 34 & 27 & 35 & 5 \\
\hline Austria & 28 & 4,13 & 42 & 22. & 21 & 38 & 13 \\
\hline Bulgairia & 29 & 4,06 & 11 & 14 & 23 & 50 & 55 \\
\hline Colômbia & 30 & 4,06 & 41 & 38 & 15 & 13 & 52 \\
\hline Federaçäo Russa & 31 & 4,03 & 3 & 10 & 47 & 29 & 57 \\
\hline Unuguait & 32 & 4,01 & 36 & 26 & 36 & 2 & 56 \\
\hline China & 33 & 4,01 & 9 & 23 & 40 & 46 & 36 \\
\hline Suiça & 34 & 3,97 & 43 & 42 & 17 & 49 & 7 \\
\hline Argentina & 35 & 3,97 & 55 & 29 & 26 & 3 & 54 \\
\hline Africa do Sul & 36 & 3.95 & 39 & 56 & 16 & 30 & 21 \\
\hline israel & 37 & 3,94 & 28 & 40 & 32 & 28 & 39 \\
\hline Japăo & 38 & 3,75 & 33 & 52 & 54 & 26 & 3 \\
\hline Bangladesh & 39 & 3,74 & 18 & 53 & 42 & 37 & 37 \\
\hline Malàsia & 40 & 3,70 & 40 & 36 & 51 & 32 & 15 \\
\hline Romênia & 41 & 3,70 & 23 & 31 & 35 & 51 & 47 \\
\hline Zimbabwe & 42 & 3.66 & 2 & 57 & 34 & 52 & 41 \\
\hline Malta & 43 & 3,65 & 56 & 43 & 45 & 16 & 24 \\
\hline Tailändia & 44 & 3.61 & 1 & 39 & 49 & 54 & 32 \\
\hline Italia & 45 & 3,50 & 51 & 49 & 48 & 41 & 11 \\
\hline Indonésia & 46 & 3,50 & 29 & 24 & 46 & 53 & 29 \\
\hline Peru & 47 & 3,47 & 50 & 44 & 38 & 47 & 31 \\
\hline Chile & 48 & 3,46 & 52 & 20 & 44 & 40 & 45 \\
\hline Venezuela & 49 & 3,42 & 38 & 13 & 52 & 33 & 58 \\
\hline Grúcia & 50 & 3,41 & 44 & 48 & 50 & 45 & 22 \\
\hline Brasil & 51 & 3.29 & 46 & 21 & 57 & 27 & 53 \\
\hline México & 52 & 3.28 & 47 & 45 & 41 & 44 & 51 \\
\hline India & 53 & 3.27 & 54 & 35 & 24 & 57 & 34 \\
\hline Corelia & 54 & 3,18 & 34 & 55 & 56 & 48 & 27 \\
\hline Jordânia & 55 & 2,96 & 58 & 32 & 58 & 43 & 43 \\
\hline Paquistâo & 56 & 2.90 & 53 & 54 & 37 & 58 & 33 \\
\hline Turquia & 57 & 2,67 & 22 & 58 & 53 & 55 & 50 \\
\hline Egito & 58 & 2,38 & 57 & 50 & 55 & 56 & 49 \\
\hline
\end{tabular}

Tabela 1 - Empoderamento feminino: avaliação das disparidades globais de gênero

Fonte: World Economic Forum, 2005 


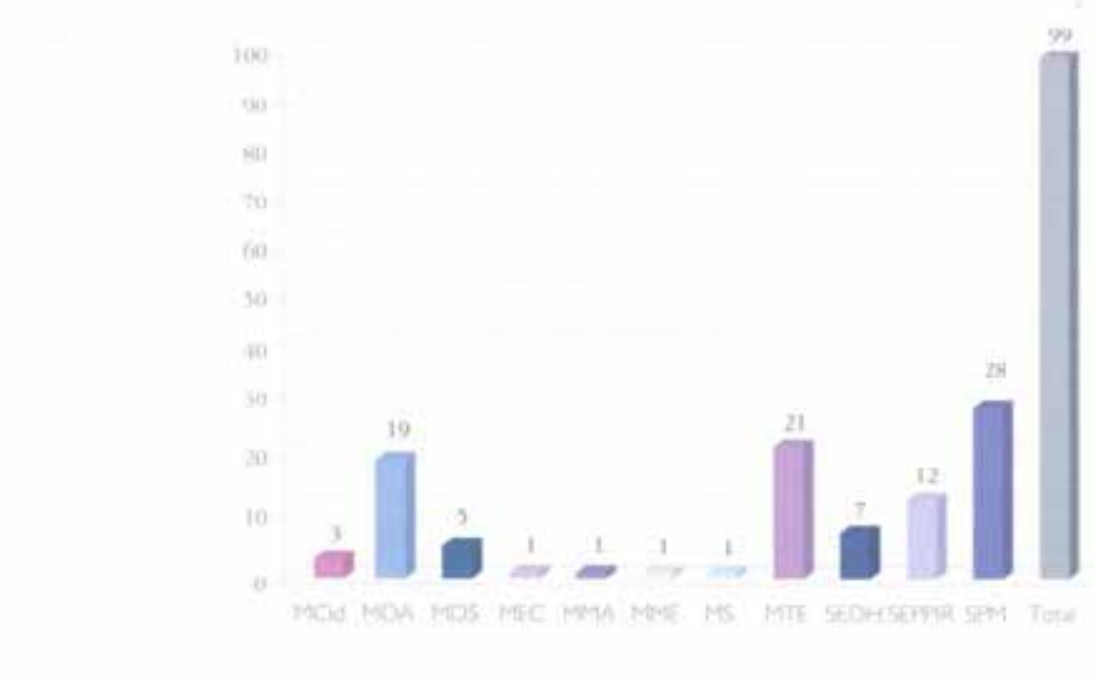

Gráfico 3 - Ações de Ministérios e Secretarias Especiais para o eixo "Autonomia, igualdade no mundo do trabalho e cidadania”, do Plano Nacional de Políticas para as Mulheres Fonte: Secretaria Especial de Políticas para as Mulheres, 2005 - 2006.

O mesmo acontece com a questão da saúde feminina na América Latina, classificada como a pior do mundo, segundo o estudo do WEF (Gráfico 4), atrás do continente africano e asiático. Mesmo assim, no Brasil, os números apontam crescimentos e união dos organismos públicos com o assunto (vide Gráfico 5). 


\section{SAÚDE E BEM-ESTAR}

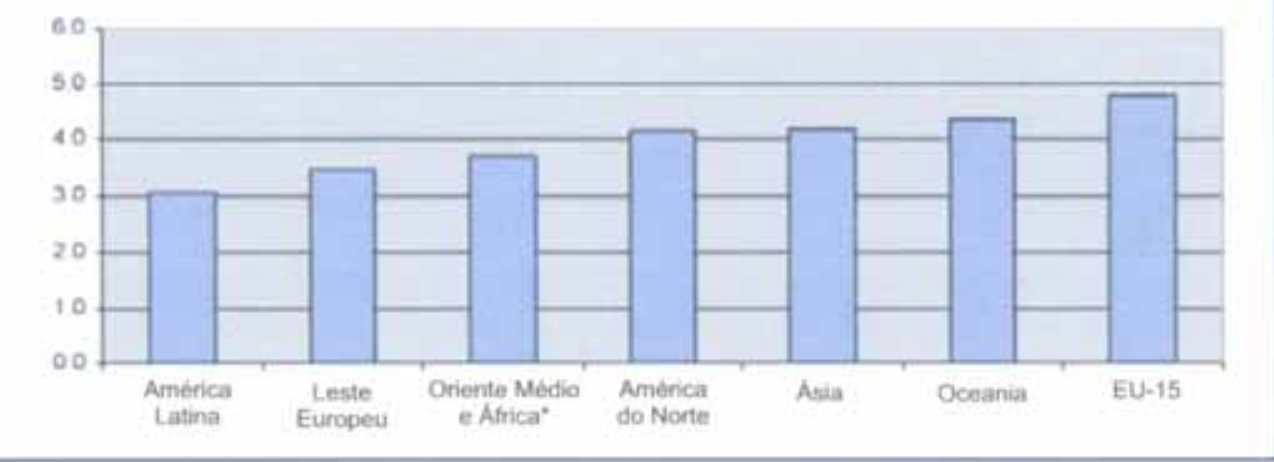

Gráfico 4 - Empoderamento feminino - Saúde e Bem-Estar Fonte: World Economic Forum, 2005.

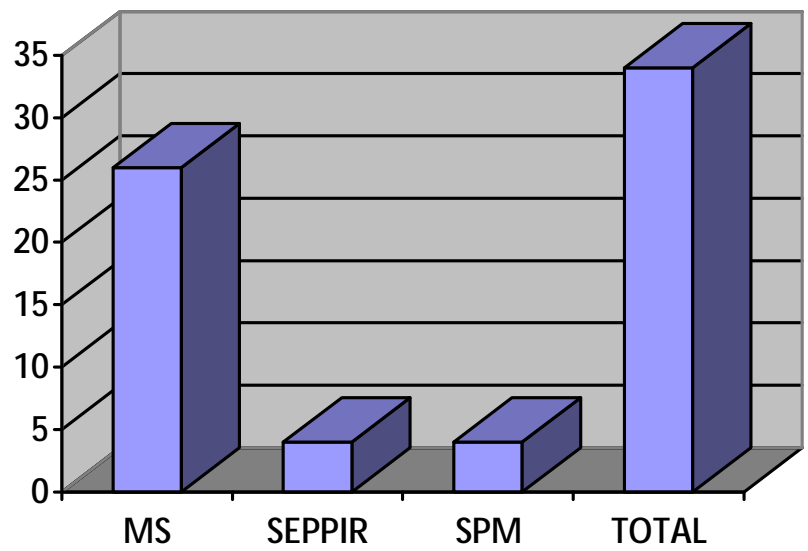

Gráfico 5 - Ações de Ministérios e Secretarias Especiais para o eixo "Saúde das mulheres e direitos sexuais e reprodutivos", do Plano Nacional de Políticas para as Mulheres -

Fonte: Secretaria Especial de Políticas para as Mulheres, 2005 - 2006

As bases estruturais econômicas, históricas e da comunicação na formação da misogenia e das distintas formulações ideológicas que lhe deram sustentação no decorrer dos séculos são bases teóricas das políticas reformistas defendidas pela maioria dos movimentos feministas contemporâneos. 
De todos os aspectos das questões de gênero nenhum pode ser observado e analisado separadamente, pois são partes constitutivas de uma narrativa milenar da luta feminina pela afirmação dos direitos humanos, seja daqueles direitos idênticos aos dos homens, seja daqueles peculiares às mulheres. Não é possível desvincular a ação pela saúde das reivindicações econômicas, trabalhistas e políticas. A emancipação feminina transcende o setor de saúde e se define como a união de direitos em todos os aspectos sociais.

1.3 - Indústria cultural, mulheres e saúde

Desde sua criação, os veículos de comunicação têm reproduzido cultural e sociologicamente o período histórico vivenciado pelo universo feminino, com representações padronizadas dos costumes das épocas retratadas, divulgando as imposições culturais e religiosas que têm comumente auxiliado na pregação dos valores e dos papéis da moral feminina.

\footnotetext{
"O primeiro dever de uma mulher é ser atraente", declara um reclame de um perfume dos anos 20. À desqualificação tradicional dos artifícios femininos sucedem as injunções do consumo: "Como 999 entre mil mulheres, você deve usar pó ruge". Martelando a idéia de que beleza pode ser comprada, o mundo do reclame educou as mulheres para uma visão consumista da beleza. (LIPOVETSKY, 2000, p.160)
}

Por meio da análise peculiar dos estudos relacionados à indústria cultural é possível generalizar as características do fenômeno em virtude das semelhanças que apresentam em suas linhas, com manifestações e trajetória de atuação relativamente idênticas.

A televisão e o rádio, desde sua origem, veiculavam produtos direcionados à família; os temas desenvolvidos priorizavam as questões ligadas à busca do casamento; mulheres traídas e/ou abandonadas; mães solteiras e rejeitadas pela família e pela sociedade; adultério; preservação da pureza feminina e pecados carnais e luxuriosos. Para uma melhor compreensão da posição da família no contexto histórico, pode-se dividir o eixo entre três influentes vias sociais: a família do provedor masculino; o "familismo"; a família no Estado de Bem-Estar Social de orientação social-democrata.

A família do provedor masculino era o benefício do seguro social público com fundamento na família do trabalhador, ou seja, concedido diretamente a ele enquanto 
mantenedor do grupo familiar. A responsabilidade familiar era o que assegurava os riscos do curso do cotidiano, como acidentes de trabalho, doença, velhice, invalidez e desemprego. Os jovens cuidavam dos adultos que lhes transferiam o patrimônio. Nessa situação, a mulher assumia uma posição passiva e reprodutora do núcleo organizativo já estabelecido.

Por outro lado, a terminação "familismo" 16 deve ser entendida como uma alternativa em que a política pública "exigia" que as unidades familiares assumissem a responsabilidade principal pelo bem-estar social. Por fim, a família na via social-democrata do Estado de BemEstar Social ${ }^{17}$ era a situação em que o governo buscava socializar antecipadamente os custos enfrentados pelo grupo familiar. Isso acontecia com as transferências específicas ao indivíduo através de serviços para o cuidado de crianças, idosos e deficientes. Essa proposta correspondia ao objetivo macroeconômico de pleno emprego, expandindo novos postos de trabalho, inclusive desenvolvendo a mão-de-obra feminina.

No Brasil, como na maioria dos países ocidentais, a definição social da família acarreta características da formação política da sociedade. Assume-se uma preposição de regras para fatores fundamentais, como a maternidade, educação, criação dos filhos, o trabalho feminino e principalmente a contribuição geral à ordem moral e social. O maior exemplo desse princípio de regras e funções familiares é o Estatuto da Família de $1939^{18}$. Porém, ao longo da História do país, foram surgindo mudanças cruciais, principalmente de ordem financeira; a população tornou-se mais numerosa, porém mais pobre, e o custo de vida das principais cidades brasileiras é alto demais para o orçamento familiar.

Hoje se discute uma nova definição de família enquanto detentora e transmissora dos recursos financeiros. A inclusão ou a ausência de determinados membros no conjunto da família altera a média salarial per capita. Assim, os programas de transmissão de renda funcionam de forma imprópria, não suprindo a necessidade familiar. Inverte-se o papel da família, ou seja, de instituição protetora, ela passa a ser o órgão ameaçado. Dadas as incapacidades tanto da família como do Estado de governar e manter o bem-estar dos indivíduos, surge a alternativa assistencialista da sociedade civil, que através de organizações

\footnotetext{
${ }^{16}$ Termo extraído do livro: Estado e Políticas Sociais do Neoliberalismo. Asa Cristina Laurell (Org.) Texto: Política de Assistência Social e a posição da família na política social brasileira.
}

17 A social-democracia é uma ideologia que surgiu em fins do século XIX e início do século XX por partidários do marxismo que acreditavam que a transição para uma sociedade socialista poderia ocorrer sem revoluções, mas por meio de uma evolução democrática. Já o Estado de Bem-estar Social ou o Welfare State é um tipo de organização política e econômica que coloca o governo como agente da promoção social e organizador da economia.

18 "O Estatuto de Família", que seria assinado pelo presidente Vargas em 1939, mas que não chegou a ser promulgado. Antes, ele sofreria as críticas de Francisco Campos e Oswaldo Aranha; outros pareceres seriam elaborados, e finalmente seria constituída uma "Comissão Nacional de Proteção da Família" da qual uma série de projetos específicos se originaria. 
não governamentais assume responsabilidades de amparo e proteção à população de forma apenas temporária.

Os avanços tecnológicos, as novas concepções do trabalho e das relações sociais de produção configuram-se atualmente apontando para uma nova ordenação mundial e ressaltando novas concepções do saber articuladas à questão do poder. Este panorama contemporâneo tem alterado de forma significativa o contexto das situações de trabalho e de vida das mulheres. Na sociedade do conhecimento, comunicar significa entender o uso das palavras dentro de um sistema em que os poderes estão recalcados nos fluxos de informação e são tão importantes na formação de valores como no embasamento de opiniões.

Mas, mesmo passando por todas essas adaptações, a família não perdeu seu poder de institucionalização e preservação da organização social no século XXI, principalmente devido ao grande apoio que obteve da televisão e do rádio na difusão dos valores morais brasileiros, e conseqüentemente da imprensa escrita.

O surgimento do interesse mercadológico pelo público feminino, e principalmente pelo seu poder de compra, concretizou-se nos veículos de comunicação, especificamente nos anúncios e textos da imprensa feminina. Nascidos no século XVII ${ }^{19}$ e estritamente dirigidos às mulheres, tais veículos abordavam no início exclusivamente assuntos amorosos, preponderantemente sob o contexto da literatura, logo depois acompanhado pelo da moda. Os direitos femininos entraram em cena nos séculos XVIII e XIX. Paralelamente, os signos da utilidade foram introduzidos e ganharam espaço: trabalhos manuais, conselhos de saúde e de economia doméstica.

Implica nesta análise classificar a imprensa feminina como uma especificidade do gênero comunicacional, uma questão polêmica ao se entender que o adjetivo "feminina" objetiva refletir o universo das mulheres, representando suas aspirações informativas e literárias. Todavia, normalmente, o conteúdo do segmento não representa a mulher, omitindo seus interesses por política, economia e assuntos sociais. BUITONI afirma: a imprensa feminina é aquela dirigida e pensada para mulheres. "A feminista, embora se dirija ao mesmo público se distingue pelo fato de defender suas causas".

A ineficiente distribuição de seus exemplares acontecia devido às distâncias entre as comunidades e o fato de os meios de transporte e o sistema de correio ainda não serem suficientemente desenvolvidos, o que ocasionava a ausência de impressos factuais devido à

\footnotetext{
${ }^{19}$ BUITONI explica que a imprensa feminina surgiu no mundo ocidental no final do século XVII, com o jornal Lady's Mercury
} 
falta de tempo hábil para a informação chegar às leitoras. Porém, não apenas por uma questão de tecnologia, a comunicação deteve-se inicialmente em assuntos basicamente de ordem secundária - como questões sentimentais, culinária, ficção, entre outros. $\mathrm{O}$ entretenimento pacífico, despolitizado e pouco reivindicativo era o que se esperava da mulher que, ao tomar contato com tais veículos, construiria no imaginário feminino heróis, princesas e modelos de felicidade.

MATTELART explica que as condições de acaso embutidas no ideal de satisfação feminina contextualizam o destino individual em um plano mais preponderante do que as conquistas sociais.

La mayor represión que ejerce lo que en otra ocasión denominábamos 'el orden del corazón, orden que preside la organización del discurso melodramático, consiste en desistir cualquier forma de lucha contra las desiguladades sociales (que por otra parte son reconocidas) por medio de una explicación difundidísima: solo el amor pode ayudar a franquear las barrerras de clase. La solucion no sólo es individual (nunca coletiva), sino que, además, depende del milagro del amor. El amor, por otra parte, se convierte en el eje de explicación universal, a partir del cual se resuelven, negándolas, las contardiciones sociales, pues el orden social injusto tiene dos ayudantes: la naturaleza y la fatalidaded. (1982: p; 37)

Nessa questão, BOSI (2000) complementa que a caracterização da comunicação de massa sobre o uso da imagem de pessoas famosas pelas mídias nada mais representa do que uma tentativa de "desrealização" da vida opressiva e árdua da mulher, uma alienação de seus problemas reais.

\begin{abstract}
A interpretação freudiana procura abranger sobre o mesmo conceito todas as atividades de "desrealização" de que é capaz o espírito humano: arte, mito, contos folclóricos e, acrescentaríamos, as infinitas imagens de vítimas e heróis que povoam a imprensa feminina de nossos dias (...) A imprensa feminina se ocupa largamente com a vida de artistas, princesas, campeões, playboys, que constituem o "Olimpo" da cultura de massas e que, por isso, são denominadas "personagens olimpianas" (...). (2000, pp. 135 e 142)
\end{abstract}

Um dos primeiros periódicos feministas foi o L’Athénée des Dames, escrito na França, em parte como conseqüência da Revolução Francesa, na Itália e Alemanha. "Apesar do correio sentimental, suas profissionais buscavam a luta, no que não eram acompanhadas pelas 
leitoras, que lhes escreviam dizendo ser a resignação a solução para os problemas femininos. Foi fechado em 1809, por ordem do imperador", comenta BUITONI.

Por questões ligadas ao desenvolvimento nacional, o nascimento das revistas femininas no Brasil foi posterior ao histórico da mídia impressa na Europa. As imposições culturais designavam às brasileiras pouca liberdade de ação e estas apenas saíam de casa em momentos raros, acompanhadas de seus maridos. As meninas começaram a freqüentar a escola na metade do século XIX e a alfabetização tardia do gênero contribuiu para sua submissão e, conseqüentemente, para a não reivindicação do acesso à informação.

BUITONI menciona O Espelho Diamantino, lançado em 1827, como o primeiro periódico feminino brasileiro. Os assuntos publicados eram: política, literatura, belas-artes e moda. Logo após, foram surgindo outros nomes: O Espelho das Brazileiras (1831), A mulher do Simplício e a Fluminense Exaltada (ambos editados de 1832 a 1846), Jornal de Variedades (1835), Relator de Novellas (1838) e Espelho das Bellas (1841). Todos seguiam uma mesma linha editorial, tradicionalmente unilateral na pregação dos valores da época.

No século XIX, o perfil noticioso e publicitário era pouco desenvolvido no Brasil; os impressos para o público feminino eram especificamente voltados para o caráter opinativo, e apenas os relatos de viagem e anúncios de teatro eram o que havia de informativo. Nessa época, os periódicos serviam para combater o inimigo político.

Moda e literatura se uniam para criar uma espécie de necessidade temporal, uma de acompanhamento da narrativa, outra de "atualização" com o que se usava na Europa. Ambas ligavam-se ao tempo, dando um certo caráter jornalístico às publicações - além do noticiário cultural, este sim, bastante jornalístico. (...) A imprensa ainda da classe dominante, era a única que tinha voz no processo político.(BUITONI, 1990, p. 41)

Já no século XX, com o advento da industrialização, o crescimento das cidades e a chegada dos imigrantes, nota-se o primeiro grande avanço da instrução pública. As eleições e a formação da classe operária também interferiram no papel da imprensa e, por volta de 1914, surgiu a primeira grande revista brasileira fundada por uma mulher, Virgilina de Souza Salles, com o nome de Revista Feminina. Logo após, vieram inúmeras revistas, como Marie Claire, uma das mais antigas publicações femininas, lançada em 1937 na França, que parou de circular durante a Segunda Guerra Mundial e voltou a ser editada em 1954. No Brasil, a 
editora Globo é a detentora da sua marca e comercialização. E a revista Claudia, lançada em 1961, um dos segmentos mais influentes, publicada pela Editora Abril. ${ }^{20}$

Um dos artifícios em que a mídia impressa feminina se apóia para persuadir a leitora é a linguagem. Os textos das matérias e das propagandas são elaborados cuidadosamente, buscando uma cumplicidade na relação revista/leitora, fator que faz com que o veículo informativo chegue a se posicionar como "uma amiga e fiel conselheira".

As revistas apresentam também dicas de beleza e de amor, na tentativa quase subconsciente de transformar a leitora na "mulher-modelo". Já as frases são caracterizadas pelo discurso imperativo, como: "Perca dez quilos em dois meses", "Trabalhe, cuide da casa e ainda encontre tempo para ser feliz", entre outras. As estratégias interacionais se baseiam na vinculação publicitária e jornalística para criar o estigma da mulher moderna na comunicação estabelecida. Por meio da linguagem confunde-se quem é leitora e quem é revista, numa tentativa de aproximação que inverte papéis e molda comportamentos, sendo o objetivo principal o lucro dos anúncios dos produtos ali divulgados.

O discurso traz em seu conteúdo uma mensagem persuasiva dirigida às ações que devem ser tomadas pelas mulheres. O fato é que ao selecionar uma mídia que tenha uma linha editorial compatível com seus interesses pessoais, a mulher acredita que o veículo seja um reflexo de seus pensamentos e suas atitudes. Todavia, o que ocorre é uma via dualista; sua manifestação é o reflexo da mídia, cujo perfil é delimitado por meio de pesquisas de mercado e segundo as tendências comerciais e comportamentais em vigência.

Outra característica da linguagem utilizada pela mídia para a persuasão das mulheres se refere à didática dos textos produzidos. As revistas tendem a não complicar a vida da leitora, com termos ou conceitos de difícil compreensão. Essa prática é explicada por Adorno (in COHN, 1989) na conceituação da indústria cultural — isto é, os meios de comunicação servem-se dos momentos de lazer para a alienação do indivíduo, momentos que devem existir apenas para diversão e não para a formação social e cidadã. A cultura, assim, torna-se algo fácil e deve ser vendida como mercadoria às massas no contexto de popularização dos assuntos, escondendo-se a verdadeira prática cultural que é a acessibilidade aos produtos por ela produzidos.

\footnotetext{
${ }^{20}$ Grupos Abril e Globo são os maiores conglomerados de comunicação do Brasil; dominam praticamente todos os segmentos de público por diferentes mídias. Mesmo com administração familiar, as duas empresas controlam sozinhas praticamente toda a rede de comunicação nacional. Só a Globo possui 5 estações de TV, 108 afiliadas de TV aberta, 15 emissoras de AM e FM, além de sistemas por assinatura, uma editora, entre outros. Fonte: Enciclopédia Contemporânea da América Latina e do Caribe.
} 
Nessa lógica, a comunicação impressa se torna um método mercadológico intimamente ligado à prática da didática dos textos produzidos que, por intermédio de informes publicitários, jornalismo de serviços e matérias vendidas extremamente claras e precisas, resultam na venda dos produtos de clientes, patrocinadores e apoiadores da mídia.

As fotos, a posição do texto e a escolha da formatação também são características trabalhadas pela comunicação persuasiva. O visual colorido e agradável oferece um dinamismo de apreensão rápida e descontraída na qual se busca o lazer e a fácil compreensão dos temas. O fato de a diagramação ser trabalhada com o perfil do entretenimento - muito papel para pouco texto: muitas cores, fotos, box e desenhos - favorece, por meio de renovações tipográficas, o exercício da interpretação.

Um exemplo é a confecção das revistas femininas com materiais de boa qualidade, promovendo alta durabilidade e rotatividade, condição que aumenta o número de potenciais leitoras por exemplar publicado. Ao contrário dos jornais, as revistas investiram no públicoalvo feminino e conseguiram se definir como uma mídia de referência ao gênero.

\begin{abstract}
A fotografia e o desenvolvimento das técnicas de impressão fizeram da imprensa feminina uma mídia cada vez mais visual. (...) Nas revistas e jornais do início do século, a foto conservava a linguagem de suas origens - desenho e pintura -, documentando estaticamente pessoas, ou determinadas cenas (inaugurações, formaturas, competições esportivas etc.). Somente mais tarde, a foto de imprensa vai tornar-se mais "jornalística" ao incorporar o movimento, em parte por influência do cinema e até dos quadrinhos, e também pelo progresso técnico, se bem que existam até hoje essas fotos tipo "retrato", mesmo onde não haveria necessidade. Imagem/texto: essa, a dupla intimamente ligada dentro da revista, com mais atração ainda se for feminina. A imagem vira texto, com séries de fotos construindo verdadeiras "frases visuais"; e o texto vira imagem quando recorre a figuras de estilo que nos fazem visualizar a pessoa ou a cena, ou sugerem emoções e sentimentos. O texto imagético, a imagem textual: um casamento que deu muito certo nas revistas, principalmente femininas. (BUITONI, 1990, pp. 18 e 19)
\end{abstract}

Há uma carência de informação concisa relacionada à mulher na grande imprensa, e as revistas femininas, por trabalharem com periodicidade mensal, não divulgam os acontecimentos factuais, como lançamentos de filmes, peças, cobertura de fóruns, campanhas preventivas, ou mesmo o acompanhamento das relações do governo para com a mulher brasileira. A cobertura deve se adequar às certezas das manchetes; cabe então, neste aspecto, a opção de entrevistar as personalidades da televisão, principalmente das telenovelas, pois não existem dúvidas de que nos próximos meses, elas ainda serão motivo de atração e audiência.

De todas as características levantadas pela indústria cultural destinada à mulher, conclui-se que os desejos femininos estão subjacentes e fortemente interpretados por um 
grande anseio capitalista de aquisição de produtos e serviços, cujos artifícios tendem a promover a tríplice integração do bem-estar físico, social e familiar. Frente a essa linha de comunicação, o assunto saúde seguiu a tendência e igualmente atrelou sua divulgação aos valores incorporados à mulher. BUITONI (1990), comentando sobre saúde no início da comunicação impressa feminina, ressalta que o principal objetivo não era instruir a mulher sobre as principais mazelas sofridas pela época, mas sim informar a mãe responsável e dedicada sobre como cuidar de seus filhos e de sua família e preveni-los das doenças comuns.

Embora apareçam comumente na indústria cultural, as divulgações sobre saúde são anúncios e matérias que, em grande parte, direcionam-se à venda de cosméticos, tratamentos diversificados e terapias milagrosas. Ao sonegar informações importantes, de caráter preventivo, em detrimento dos novos aparelhos cada vez mais sofisticados e das técnicas mais modernas, a mídia deixa de cumprir seu papel de oferecer decisões com consciência.

Entretanto, existem motivos para concluir a omissão do assunto saúde nas divulgações femininas. Primeiro, porque escrever e anunciar sobre doenças não é um assunto de fácil análise, muito menos em governos com baixos índices de desenvolvimento e com insuficientes políticas públicas de saúde, como no Brasil. Segundo, porque a opção por uma linguagem de cumplicidade e amizade com as leitoras oferece soluções milagrosas e dicas para "alcançar a felicidade".

Portanto, ao optar por colocar na capa da revista, no rádio ou na televisão o sucesso e fama das celebridades, os veículos vendem um outro contexto de realidade às mulheres, tornando-se uma escapatória dos seus reais problemas e um convite ao mundo das ilusões. Entretanto, tratando-se do campo das doenças, temos uma cumplicidade às avessas: a linguagem das enfermidades não combina com o mundo idealizado pela indústria cultural.

Um exemplo interpretativo e didático comumenente empregado nas mídias é o uso de desenhos, preferencialmente recorrido por ser menos agressivo e chocante. Por exemplo, utiliza-se o recurso para a temática do auto-exame das mamas; porém, não se mencionam os tipos de cirurgia existentes, quais e onde serão os cortes, em quais casos são necessários retirar toda a mama ou como reconstruir os seios, planos de saúde, leis e direitos, etc.

Embora um dos papéis dos veículos de comunicação seja a descrição minuciosa e a divulgação plena da veracidade dos fatos, não são constantes as abordagens adequadas nas divulgações dos principais entraves contemporâneos vivenciados pela mulher. Este é o caso da área de saúde na abordagem da sociedade de massa: escassa de respaldos em informações concisas, cujos teores não relacionam os diferentes setores do Estado. Talvez, ao contrário, se 
a ação midiática fosse contínua e adequadamente trabalhada, certamente contribuiria mais com a diminuição nos gastos de prevenção das doenças.

Nas manifestações da indústria cultural voltadas às mulheres, espera-se dos meios cumplicidade na melhoria da sua qualidade vida e cobranças das incorporações de conceitos sobre as relações de gênero nas políticas públicas e nas críticas governamentais.

Por meio de ações determinantes na aceitação das diferenças e na garantia de mudanças comportamentais, faz-se necessário que haja menos destaque à ditadura da beleza, constantes compromissos com indivíduo, e mais representatividade no que tange à realidade das diversidades de gênero. Dá-se nessa linha a luta contra a exclusão social, o favorecimento de campanhas de comunicação sobre saúde, cujas características devem visar à prática da defesa da garantia dos direitos humanos e de núcleos organizativos de empoderamento feminino.

A indústria cultural, por meio da propagação suprema dos cuidados em relação ao binômio saúde-beleza, divulga um caminho modulado de felicidade individual, ideais implícitos à lógica mercadológica e competitiva. Nesse aspecto, a concepção de saúde se confunde na sociedade de massa, especificamente nas comunicações dirigidas à mulher, com a venda de cosméticos, tratamentos diversificados e terapias prodigiosas. $\mathrm{O}$ excessivo apelo dos produtos de transformação corporal se embute no desligamento dos valores de emancipação feminina. A verdadeira abordagem sobre saúde da mulher, quando não é superficial, é mínima se comparada a outras tantas relacionadas ao consumo, o que justifica nas palavras de Del Priori (2003) a condenação das mulheres a ser apenas um corpo, o seu corpo. 


\section{Capítulo II}

Câncer de mama no Brasil 
Atualmente, a representatividade simbólica do câncer alcança uma valorização igual ou superior ao seu grau de mortalidade ou sofrimento. As características da enfermidade se incorporam ao quadro de doenças da contemporaneidade e a aquisição da doença se torna tão demasiadamente temerosa à população quanto as fatalidades e conseqüências de sua contração. A fantasia constitutiva da enfermidade faz com que fatores emocionais e psicológicos se tornem elementos influenciadores do quadro clínico do indivíduo portador e, principalmente, das práticas de ação e reação à doença.

As linguagens utilizadas para a designação da doença e as campanhas de comunicação com vistas à prevenção demonstram o quão significativo é atuar nos processos das mensagens educativas sobre o assunto. A enunciação aliada aos demais campos epistemológicos relacionados ao câncer oferecem elementos transgressores comportamentais, informações que em máximo grau de entendimento podem prevenir, curar e até erradicar a doença.

$\mathrm{Na}$ atualidade, a temática da doença está intimamente ligada à multidisciplinaridade de áreas, como medicina, estética, enfermagem, psicologia, literatura, comunicação, entre outras. Sendo assim, além da geração de empregos, da multiplicação de profissionais especializados no assunto, existem ínumeros institutos de pesquisa espalhados pelo mundo, e a cada ano, surgem novas pesquisas cujas finalidades são: detectar potenciais produtos cancerígenos; apontar novas opções de tratamentos e prevenção; e traçar um panorama demográfico e estatístico dos índices de desenvolvimento da doença.

O crescimento dos estudos voltados para a doença, mais a mobilização de recursos para a criação de tratamentos e medicamentos, faz com que o câncer seja um fator de influência até no mercado econômico mundial. Inclusive, por meio de organizações nãogovernamentais, instuições assistenciais e campanhas de incentivo à doação financeira ou ao trabalho voluntário ${ }^{21}$, a doença é também, hoje, um dos elementos-chave do crescimento da filantropia.

\footnotetext{
${ }^{21}$ No Brasil, a Lei $n^{\circ}$ 9.608/98 caracteriza como trabalho voluntário a atividade não remunerada prestada por pessoa física a entidade pública de qualquer natureza, ou a instituição privada de fins não lucrativos que tenha objetivos cívicos, culturais, educacionais, científicos, recreativos ou de assistência social, inclusive de mutualidade.
} 
A OMS - Organização Mundial de Saúde, agência subordinada à ONU - Organização das Nações Unidas, que tem a missão de desenvolver ao máximo possível o nível de saúde de todos os povos, afirma:

Cancer is the world's second biggest killer disease, but one of the most preventable noncommunicable chronic diseases. Cancer killed 7.6 million people in 2005, three quarters of whom were in low and middle income countries. By 2015, that number is expected to rise 9 million and increase further to 11.5 in $2030 .{ }^{22}$

Na definição técnica do Instituto Nacional de Câncer - INCA, câncer é o nome dado a um conjunto de mais de 100 doenças que têm em comum o crescimento desordenado maligno - de células que invadem os tecidos e órgãos, podendo se espalhar para outras regiões do corpo, o que configura o fenômeno da metástase. Dividindo-se rapidamente, essas células tendem a ser muito agressivas e incontroláveis, determinando a formação de tumores acúmulo de células - cancerosos ou neoplasias ${ }^{23}$ malignas.

Dentre todos os tipos existentes de câncer, o da mama é citado como a neoplasia de mais difícil controle. Apesar de existirem algumas associações ao surgimento do tumor, como idade avançada, casos genéticos de parentes de primeiro grau que contraíram a doença, uso prolongado de terapias hormonais, anticoncepcionais, de álcool e tabaco, obesidade, ou mesmo exposição à radiação ionizante, o câncer de mama ainda possui uma origem desconhecida. Qualquer mulher é passível de desenvolver a doença e, apesar de não muito comum, homens também podem contraí-la.

Pela definição histórica, conforme SOMMER (1976, p.14) explica, a doença acompanha a evolução da medicina.

Milênios antes de Cristo a medicina egípcia reconhecia tumores na mama, embora fosse incapaz de diferenciar entre benignos e malignos. Os egípcios, normalmente, não se arriscavam a operá-lo. Cerca de $500{ }^{\mathrm{a}} \mathrm{C}$., época em que a medicina grega e romana realizou suas maiores descobertas, se destacou o mau prognóstico de certos tumores da mama que apresentavam raízes. Estes deram origem ao termo CÂNCER, pela semelhança que apresentavam com o caranguejo marinho (...) O cirurgião francês Jean L. Petit foi quem primeiro recomendou sua extirpação juntamente com as lesões mamárias que apresentassem raízes, pois as considerava como extensões destas.

\footnotetext{
${ }^{22}$ Publicado em WHO Communications: The World Health Organization's fight against cancer: strategies that prevent, cure and care, World Health Organization 2007.

${ }^{23}$ Neoplasia é o termo que designa alterações celulares que acarretam um crescimento exagerado dessas células, ou seja, proliferação celular anormal, sem controle e autônoma, na qual reduzem ou perdem a capacidade de se diferenciar, em consequência de mudanças nos genes que regulam o crescimento e a diferenciação celulares. A neoplasia pode ser maligna ou benigna. (neo significa novo e plasia é relativo a tecido).
} 
No Brasil, o INCA é o órgão que realiza estudos e mapeamentos da incidência dos diferentes tipos de cânceres existentes, considerando todas as regiões do território nacional. Uma das referências utilizadas para esta pesquisa é o relatório das estimativas do ano 2008, válidas também para 2009, devido ao fato de a pesquisa ser realizada a cada dois anos.

Conforme a Tabela 2, o relatório frisa que neste ano, são esperados 231.860 mil casos novos de câncer para o sexo masculino e 234.870 para sexo feminino, sendo o total de 466.730 mil. Estima-se que o câncer de pele não melanoma ${ }^{24}$ (115.010 mil casos novos) será o mais incidente na população brasileira, seguido pelos tumores de próstata (49.530 mil), mama feminina (49.400 mil), pulmão (27.270 mil), cólon e reto (26.990 mil), estômago (21.800 mil) e colo do útero $(18.680 \mathrm{mil})^{25}$.

Estimativas, para o ano 2008, de número de casos novos por câncer, em homens e mulheres, segundo localização primária.*

\begin{tabular}{|l|r|r|r|}
\hline Localizaçáo Primária & \multicolumn{3}{c|}{ Estimativa de casos novos } \\
\hline Neoplasia Maligna & Masculino & \multicolumn{1}{|c|}{ Feminino } & \multicolumn{1}{c|}{ Total } \\
\hline Próstata & 49.530 & - & 49.530 \\
\hline Mama Feminina & - & 49.400 & 49.400 \\
\hline Traquéia, Brônquio e Pulmáo & 17.810 & 9.460 & 27.270 \\
\hline Cólon e Reto & 12.490 & 14.500 & 26.990 \\
\hline Estômago & 14.080 & 7.720 & 21.800 \\
\hline Colo do Útero & - & 18.680 & 18.680 \\
\hline Cavidade Oral & 10.380 & 3.780 & 14.160 \\
\hline Esốfago & 7.900 & 2.650 & 10.550 \\
\hline Leucemias & 5.220 & 4.320 & 9.540 \\
\hline Pele Melanoma & 2.950 & 2.970 & 5.920 \\
\hline Outras Localizaçōes & 55.610 & 62.270 & 117.880 \\
\hline Subtotal & 175.970 & 175.750 & 351.720 \\
\hline Pele não Melanoma & 55.890 & 59.120 & 115.010 \\
\hline Todas as Neoplasias & 231.860 & 234.870 & 466.730 \\
\hline "Números arredondados para 10 ou múttiplos de 10. & & & \\
\hline
\end{tabular}

Tabela 2 - Estimativas, para o ano de 2008, de número de casos novos por câncer, em homens e mulheres, segundo localização primária - Fonte: MS/INCA - estimativas de câncer no Brasil 2008

\footnotetext{
${ }^{24}$ Existem basicamente dois tipos de câncer de pele: o não melanoma, que é mais comum, e o melanoma. O primeiro é mais comum e raramente causa a morte do paciente, e o segundo é um tipo com maior malignidade e mortalidade. O melanoma na maioria das vezes se parece a uma pinta, sarda ou mancha de nascença.

${ }^{25}$ Para estimar o número de casos novos de câncer esperados para todas as unidades da federação (UF) e respectivas capitais para o ano 2008, utilizou-se o método que permite obter a taxa de incidência de câncer para uma determinada região, multiplicando-se a taxa observada de mortalidade da região pela razão entre os valores de incidência e mortalidade da localidade onde exista RCBP - Registros de Câncer de Base Populacional.
} 


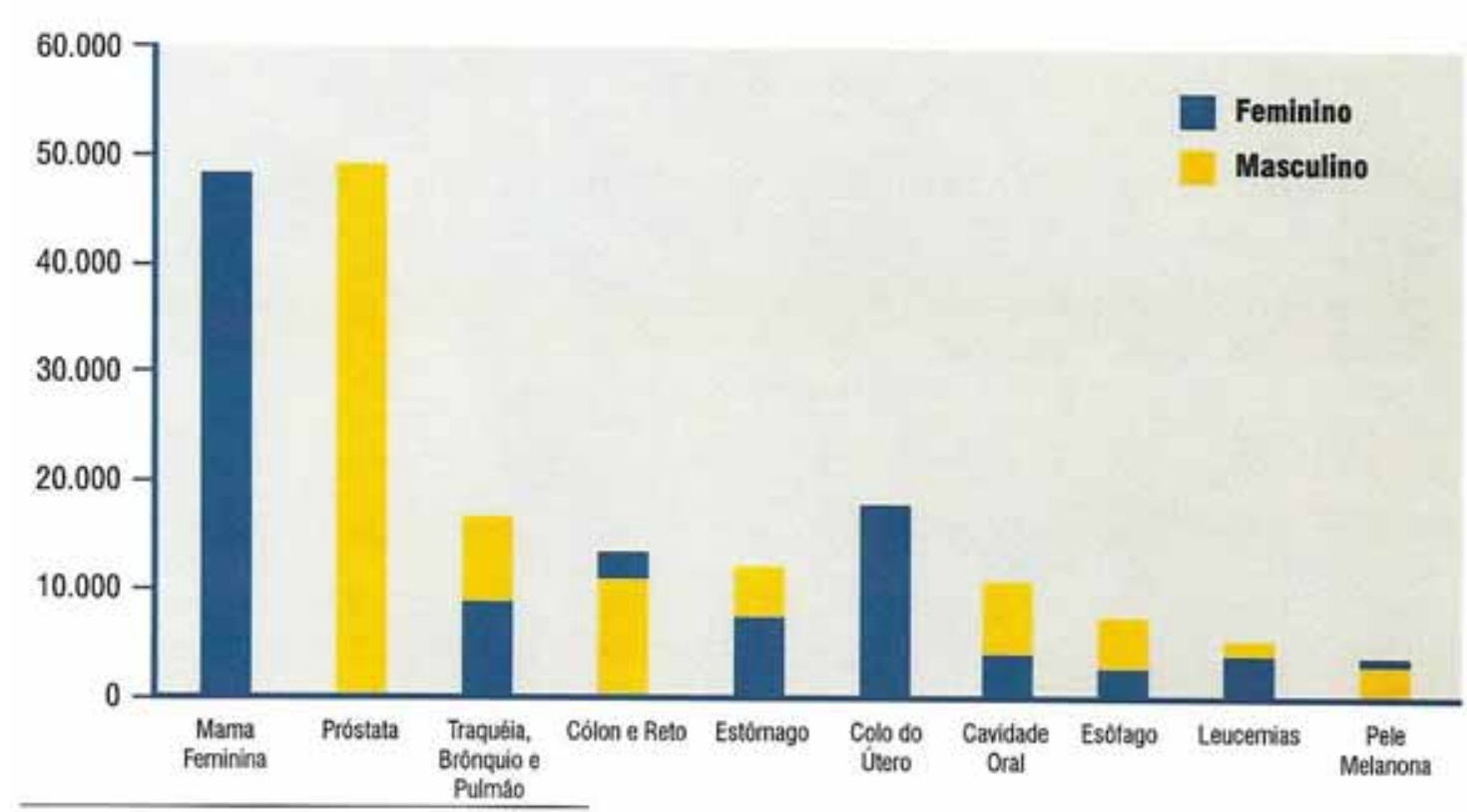

Fonte: MS/Instituto Nacional de Cancer - INCA

Gráfico 6 - Estimativas de câncer no Brasil no ano de 2008 - Fonte: MS/INCA

Nota-se no estudo que existem peculiaridades típicas da falta de prevenção que ocorre no país; entretanto, o crescimento da doença foi acompanhado similarmente a todas as outras nações. Faltam nessas estimativas classificações por faixa econômica, porém é possível presumir alguns dados devido à disparidade regional. Por exemplo, o câncer de colo de útero devido à falta de acompanhamentos ginecológicos na região norte é mais incidente do que o câncer de mama na região sul (vide Tabela 3).

O câncer de mama é o segundo tipo de câncer mais freqüente no mundo e o mais comum entre as mulheres. A cada ano, cerca de $22 \%$ dos casos novos de câncer em mulheres são de mama. Segundo o Inca, o risco estimado de câncer de mama para o Brasil é de 51 casos a cada 100 mil mulheres. Na região Sudeste, o câncer de mama é o mais incidente entre as mulheres com um risco estimado de 68 casos novos por 100 mil. Sem considerar os tumores de pele não melanoma, esse tipo de câncer também é o mais freqüente nas mulheres das regiões Sul (67/100.000), Centro-Oeste (38/100.000) e Nordeste (28/100.000). Na região Norte, é o segundo tumor mais incidente (16/100.000). 


\begin{tabular}{|c|c|c|c|c|c|c|c|}
\hline Estados & $\begin{array}{c}\text { Mama } \\
\text { Feminina }\end{array}$ & $\begin{array}{l}\text { Traquéia, } \\
\text { Brônquio } \\
\text { e Pulmão }\end{array}$ & Estômago & $\begin{array}{l}\text { Colo do } \\
\text { Útero }\end{array}$ & Próstata & $\begin{array}{c}\text { Cólon e } \\
\text { Reto }\end{array}$ & Esôfago \\
\hline Acre & 40 & 40 & 50 & 40 & 70 & 20 & 20 \\
\hline Alagoas & 330 & 170 & 120 & 270 & 370 & 90 & 50 \\
\hline Amapá & 40 & 50 & 80 & 70 & 60 & 20 & 20 \\
\hline Amazonas & 250 & 280 & 300 & 460 & 390 & 140 & 40 \\
\hline Bahia & 1.790 & 820 & 900 & 970 & 2.520 & 740 & 400 \\
\hline Ceará & 1.540 & 760 & 1.090 & 770 & 2.010 & 460 & 330 \\
\hline Distrito Federal & 660 & 270 & 230 & 220 & 540 & 360 & 90 \\
\hline Espírito Santo & 830 & 490 & 520 & 460 & 950 & 440 & 250 \\
\hline Goiás & 1.040 & 740 & 470 & 570 & 1.290 & 570 & 220 \\
\hline Maranhão & 310 & 240 & 240 & 630 & 490 & 140 & 40 \\
\hline Mato Grosso & 370 & 320 & 260 & 260 & 650 & 180 & 110 \\
\hline Mato Grosso do Sul & 560 & 360 & 290 & 300 & 720 & 320 & 140 \\
\hline Minas Gerais & 4.280 & 2.270 & 2.100 & 1.360 & 5.050 & 2.160 & 1.400 \\
\hline Pará & 610 & 380 & 560 & 790 & 640 & 250 & 60 \\
\hline Paraíba & 490 & 180 & 250 & 230 & 550 & 150 & 100 \\
\hline Paraná & 3.010 & 1.910 & 1.830 & 1.350 & 3.430 & 1.950 & 1.050 \\
\hline Pernambuco & 2.010 & 830 & 700 & 1.020 & 2.260 & 670 & 280 \\
\hline Piaú & 330 & 190 & 140 & 330 & 550 & 120 & 50 \\
\hline Rio de Janeiro & 7.680 & 3.390 & 2.160 & 2.120 & 5.950 & 3.890 & 1.000 \\
\hline Rio Grande do Norte & 520 & 270 & 290 & 250 & 640 & 200 & 70 \\
\hline Rio Grande do Sul & 4.880 & 3.990 & 1.600 & 1.610 & 4.430 & 3.060 & 1.510 \\
\hline Rondônia & 130 & 140 & 120 & 120 & 250 & 60 & 40 \\
\hline Roraima & 30 & 20 & 30 & 40 & 60 & 20 & 20 \\
\hline Santa Catarina & 1.610 & 1.310 & 930 & 510 & 1.640 & 940 & 550 \\
\hline São Paulo & 15.640 & 7.570 & 6.370 & 3.500 & 13.310 & 9.890 & 2.640 \\
\hline Sergipe & 310 & 170 & 110 & 250 & 430 & 110 & 40 \\
\hline Tocantins & 110 & 110 & 60 & 180 & 280 & 40 & 30 \\
\hline Brasil & 49.400 & 27.270 & 21.800 & 18.680 & 49.530 & 26.990 & 10.550 \\
\hline
\end{tabular}

*Números arredondados para 10 ou múltiplos de 10

Tabela 3 - Estimativas, para o ano de 2008, de número de casos novos por câncer, em homens e mulheres, segundo os Estados da República - Fonte: MS/INCA - estimativas de câncer no Brasil 2008 
O grande problema dos índices de alta mortalidade de câncer de mama no Brasil é o fato de a doença ser descoberta tardiamente. No SUS - Sistema Único de Saúde ${ }^{26}$, a prioridade atual é a realização do exame clínico da mama em mulheres que procuram o sistema de saúde por qualquer razão, especialmente aquelas na faixa etária de maior risco, e os mamógrafos disponíveis devem ser prioritariamente utilizados no diagnóstico de mulher com alterações prévias diagnosticadas no exame clínico.

Era comum divulgar-se que a faixa etária mais acometida pela doença variava dos 45 aos 55 anos. Porém, os dados estão mudando significativamente. No levantamento do Inca e da Fundação Oncocentro de São Paulo, órgão de apoio da Secretaria da Saúde para assessorar a política de Câncer no Estado, reuniram-se informações de 54 hospitais paulistas no ano de 2005, e o resultado mostrou que mulheres com menos de 40 anos já respondem por $15 \%$ dos casos de câncer de mama.

Nesse contexto, ao se considerar o câncer de mama como a doença que mais atinge e mata mulheres no Brasil, a constatação do aparecimento da doença é uma conjuntura bastante delicada para todas as mulheres. Assim como as técnicas de prevenção e de tratamento necessitam de avanços tecnológicos, os valores sociais intrínsecos que a doença gera às mulheres também necessitam de estudos, análises críticas e desenvolvimento.

\footnotetext{
26 O SUS foi criado pela Constituição Federal de 1988 e regulamentado pelas Leis n. ${ }^{\circ}$ 8080/90 (Lei Orgânica da Saúde) e $\mathrm{n}^{\mathrm{o}} 8.142 / 90$, com a finalidade de alterar a situação de desigualdade na assistência à Saúde da população, tornando obrigatório o atendimento público a qualquer cidadão, sendo proibidas cobranças de dinheiro sob qualquer pretexto. O SUS é destinado a todos os cidadãos e é financiado com recursos arrecadados através de impostos e contribuições sociais pagos pela população e compõem os recursos do governo federal, estadual e municipal. Dados retirados do site: do Ministério da Saúde do Brasil: www.saude.gov.br
} 


\subsection{Mastectomia e a linguagem do câncer}

Quanto às formas de manifestação do câncer de mama, na maioria dos casos, o primeiro sinal da doença é um pequeno nódulo ${ }^{27}$ no seio. Porém, também existem outras evidências, como: mudanças de cor e tamanho, secreção nos bicos, ou mesmo uma ou mais lesões nas axilas. O diagnóstico de câncer de mama acena com diferentes possibilidades de tratamentos, no caso de constatação do caráter cancerígeno do nódulo e de seu tamanho. Os mais conhecidos são a cirurgia conservadora - a quadrantectomia - técnica que divide o seio em quatro partes e extrai apenas a parte do seio onde está localizado o nódulo, e a mastectomia técnica cirúrgica que corresponde à retirada integral da mama e do músculo peitoral ${ }^{28}$.

Tanto a cirurgia conservadora quanto a mastectomia são geralmente acompanhadas pela retirada de nódulos linfáticos da axila. Esses nódulos são estudados para saber se foram invadidos ou não pelo tumor e, só depois, orienta-se para o tratamento complementar por meio de procedimentos, como radioterapia, quimioterapia ou hormonioterapia.

Esse contexto que caracteriza a situação de diagnóstico e tratamento provoca inúmeras reações no portador de câncer de mama, dentre elas as representações simbólicas e figurativas da detecção de uma doença. As palavras relativas à doença são carregadas de fortes interpretações, como por exemplo, maligno ou begnino, células invasoras, entre outras.

Susan Sontag (2002, p.104), romancista, ensaísta e feminista é umas das autoras que descreve o caráter lingüístico das doenças, especificamente do câncer. Em sua obra A doença como metáfora, a autora explora o lado sentimental da doença; talvez pela sua própria vivência como portadora de câncer, sua obra se destaca pela análise da retórica e pela associação da imagem do câncer a importantes fatos históricos da contemporaneidade, como se observa no texto a seguir:

Descrever um fenômeno como um câncer é um incitamento à violência. $\mathrm{O}$ uso do câncer no discurso político estimula o fatalismo e justifica medidas "severas", bem como reforça poderosamente a noção generalizada de que a doença é necessariamente fatal. Aqueles que desejam exprimir indignação parecem achar difícil resistir à tendência a usar a metáfora do câncer. O conceito da doença nunca é inocente (...) Tróstki chamou Stálin de câncer do marxismo (...) John Dean explicou Watergate a Nixon: "Temos um câncer - Junto à presidência - que está crescendo."

\footnotetext{
${ }^{27} \mathrm{Na}$ ciência das doenças, a patologia, o nódulo corresponde a uma lesão sólida, elevada, com mais de $1 \mathrm{~cm}$ de diâmetro.

${ }^{28}$ Dados provenientes do site do INCA, www.inca.gov.br
} 
A escritora traça um paralelo entre a tuberculose e o câncer, explicando a diferença da terminologia e das associações feitas a cada uma das doenças. A tuberculose era poeticamente associada ao sofrimento da alma, algo como uma representação corporal metafórica dos sentimentos existentes frente à morte (SONTAG, 2002, p.27).

Thoreau, que tinha tuberculose, escreveu em 1852: "A morte e a doença muitas vezes são bonitas, como o brilho héctico da consumação". Ninguém concebe o câncer de maneira como a tuberculose era concebida, como morte decorativa e, muitas vezes, lírica. O câncer é um assunto raro e ainda escandoloso na poesia. E é inimaginável que ele confira estética à doença.

Já o câncer, nas palavras da autora, é um fato totalmente brusco; não oferece margem à poesia, pelo contrário, o signo câncer é algo de difícil resolução. Sua analogia relaciona aspectos da doença à rotina militar ou a uma guerra. As representações da doença são, mesmo que subconscientemente, pejorativas e desestimulantes a seus portadores (SONTAG, 2002, p.53).

\begin{abstract}
As metáforas relativas às idéias de controle e comando, na realidade, não são tiradas da economia, mas da linguagem militar. Assim, as células do câncer não se multiplicam simplesmente; elas são “invasoras”. (Os tumores malignos invadem até mesmo quando crescem muito "lentamente", lê-se em um manual). A partir do tumor original, as células do câncer "colonizam" regiões distantes do corpo, estabelecendo primeiro minúsculos postos avançados ("micrometástases") cuja presença é admitida, embora não possam ser detectados. Raramente as "defesas" do corpo são suficientemente vigorosas para obliterar um tumor que estabeleceu sua fonte de suprimento de sangue e consiste em bilhões de células destrutivas. Por mais "radical" que seja a intervenção cirúrgica, por maior que seja o número de "explorações" feitas na paisagem do corpo, as remissões, em sua maioria, são temporárias. As perspectivas são de que "a invasão do tumor" prossiga ou de que as células defeituosas eventualmente se reagrupem e preparem um novo assalto ao organismo.
\end{abstract}

Como toda doença, tratar de um câncer é um obstáculo corporal, psicológico e, muitas vezes, também social. A discriminação pelo olhar do outro e as mudanças de vida após o diagnóstico da doença são confrontos a serem vencidos. Embora hoje a constatação da doença não seja mais significativamente assustadora e uma sentença de morte, adjunto a todas as problemáticas, a palavra câncer carregou-se de um significado que era oposto à esperança, como indicou Sontag (2002, p.26): 
De todas as teorias formuladas a respeito do câncer, só uma, na minha opinião, sobreviveu à passagem do tempo, a saber, a de que o câncer leva, através de estágios definidos, à morte. Com isso, quero dizer que o que não é fatal não é câncer. Daí podem concluir que eu não alimento nenhuma esperança de um novo método de cura do câncer, só dos muitos casos de doenças chamadas de câncer mas que, na realidade, são só assim chamadas.

Rose Kushner (1989) também foi escritora, portadora de câncer de mama e mastectomizada. Na década de 70, por meio de uma pesquisa realizada com outras 130 mulheres que sofreram a cirurgia, idealizou um centro de aconselhamento gratuito sobre câncer de seio - onde 7.000 mulheres buscaram apoio e registraram depoimentos - e publicou o livro Por que eu? O que toda mulher deve saber sobre o câncer de seio. A obra utiliza-se da compilação dos depoimentos das mulheres vitimadas pela doença, analisando estatísticas e descrevendo a opinião de especialistas da área médica e psicológica.

A pesquisadora (KUSHNER, 1981, p.106) descreve diferentes aspectos da doença e, a princípio, o lado lingüístico, a força das expressões verbais e textuais na rotina da mulher mastectomizada se destacam como um forte elemento causador de uma preocupação permanente na vida da mulher com câncer de mama.

\footnotetext{
A paciente deve ficar alerta, principalmente, para qualquer um dos sete sinais de perigo ou de risco para câncer:

C onstipação, diarréia ou mudança nos hábitos intestinais

U lceração ou feridas de difícil cicatrização

I dentificar secreções e perdas sanguíneas

D eve-se manter sob observação o aparecimento de nódulos nos seios ou em outros lugares

A zia, indigestão e dificuldades na deglutição

D escoloração ou alterações em verrugas ou manchas

O bservar o aparecimento de tosse ou rouquidão persistentes.
}

A mistificação da doença talvez decorra de algo intrínseco ao comportamento humano e culturalmente explicável. A comunicação e o uso das palavras estão sempre carregados de emoções e sentimentos, pois sendo a cultura formadora de valores e opiniões, as concepções de dor e prazer têm um caráter espacial e temporal. A atribuição do câncer a fatores externos protege o paciente da culpa, da autocrítica e de sentimentos de impotência. 
Contudo, nessa época talvez ninguém mais queira comparar algo de terrível com o câncer. Uma vez que o interesse da metáfora deve-se precisamente a ela se referir a uma doença tão carregada de mistificação e da fantasia de inescapável fatalidade; uma vez que nossas opiniões sobre o câncer e as metáforas que lhe impusemos são um veículo das grandes insuficiências desta cultura, da nossa atitude superficial diante da morte, da nossa ansiedade com os sentimentos, das nossas reações temerárias e levianas aos nossos verdadeiros "problemas de crescimento", da nossa incapacidade para construir uma sociedade industrial avançada que regule o consumo adequadamente, e dos nossos justificados temores do curso cada vez mais violento da história (..). (SONTAG, 2002, p. 107 e 108)

Hoje, considerando uma maior acessibilidade da sociedade aos meios de comunicação, as doenças seguem uma tendência cíclica na qual a metáfora das palavras representa o poder da discriminação em qualquer que seja a região estudada. Na visão pré-moderna da doença, como cometa (SONTAG, 2002, p.53), o papel do caráter foi confinado ao comportamento da pessoa. Mesmo que a doença não seja considerada um julgamento na comunidade, ela se torna um julgamento retroativamente na medida em que põe em movimento um inexorável colapso da moral e dos costumes.

\subsection{Feminilidade, simbologia e a perda do seio}

A partir do diagnóstico médico e da ciência dos procedimentos que deverão ser adotados, a mulher enfrenta um período delicado de tomada de decisões que certamente trarão implicações psicológicas. A constatação de um tumor, a decisão do tipo de cirurgia, os tratamentos de erradicação - radioterapia, quimioterapia e hormonioterapia - são diferentes etapas a serem vivenciadas pela mulher com câncer de mama.

A mastectomia consiste na mais dolorosa conseqüência para a paciente com câncer. As representações do seio perpassam por toda a trajetória da vida da mulher, desde a identificação com a mãe, quando a menina começa a conhecer sua feminilidade, até a amamentação, época do nascimento e acolhimento dos filhos, não esquecendo a sua importância nas relações sexuais e a representatividade simbólica e cultural no reconhecimento da atratividade e beleza do corpo feminino. Ao longo da História, as mulheres sempre tiveram orgulho de seus seios; por isso, através dos tempos, a vaidade sempre foi a armadilha de morte para a razão da luta por um diagnóstico e tratamento precoce do câncer de mama. 
Rubia Zecchin (2004, p.41) desenvolveu um trabalho clínico com mulheres mastectomizadas vinculadas ao Instituto de Ginecologia e Mastologia (IGM) do Hospital São Joaquim - Beneficência Portuguesa. Sua análise identificou nos relatos das pacientes aspectos que não tratavam apenas da dor física; pelo contrário, esta foi pouco comentada, mas sim, sobre aspectos totalmente intrínsecos às dores psicológicas.

O mais evidente é a sensação de fragmentação no e do corpo, incluindo o si mesmo cortado pelo acontecimento, é como um tempo de existência sem identidade, isto é, aquela que fui, não sou mais, e não sei como ficarei, como estarei no mundo depois desta experiência. No entanto, em se tratando de uma cirurgia mutiladora, é indiscutível sua inserção tanto na ordem do corpo orgânico quanto na ordem do corpo/sujeito.

A perda e o luto são temas significativamente trabalhados dentro da área da psicanálise, e uma das razões para tal enfoque é o fato de a constituição do sujeito estar intimamente ligada à posse de objetos e pessoas. É comum o indivíduo identificar-se naquilo que possui ou com quem se relaciona. A ausência de algo tão próximo acarreta a dor da identificação pessoal, ou seja, a pessoa perde referências e certezas que conquistou durante o todo caminho da vida.

Em sua pesquisa, Freud $^{29}$ apud ZECCHIN (2004, p.119) traça um paralelo da vivência cronológica do indivíduo com a relação de apego e a conquista de tudo que é manipulável e tocável: “As crianças gostam de expressar uma relação de objeto por uma identificação: 'Eu sou o objeto'. 'Ter' é o mais tardio dos dois; após a perda do objeto, ele recai para 'ser'. Exemplo: o seio. 'O seio é uma parte de mim, eu sou o seio'. Só mais tarde: 'Eu tenho' - isto é 'eu não sou ele”.

Nas palavras da autora, ainda sob um raciocínio freudiano, a perda do objeto descaracteriza o indivíduo (ZECCHIN, 2004, p.139):

Freud distingue, pois, dor psíquica de desprazer por seu caráter específico e de angústia, pelo alto nível de investimentos ligados da primeira, mas também porque esta é uma reação ante o perigo pela perda do objeto, enquanto aquela é uma reação ante a perda real. Quanto ao luto, para Freud, passamos pelo teste de realidade e o luto exige a separação, pois o objeto não existe mais. O luto é uma tarefa finita de elaboração de uma perda. Já a dor se refere a uma experiência que pode nos exigir de forma contínua, a princípio infinita, de trabalho psíquico. A perda do seio está circunscrita entre a dor e o luto.

${ }^{29}$ FREUD, S. “Achados, Idéias, Problemas” (1941), ESB, p.335 
Já Ana Maria Barbosa (1989, p.48) descreveu, em sua dissertação Viagem ao vale da morte: estudo psicológico sobre mulheres mastectomizadas por câncer de mama, depoimentos factuais para explicar tal situação de morte e sobrevivência iniciada pela perda do seio. Em seu trabalho, a cirurgia mastectomia é uma realidade brutal cuja finalidade de situação peculiar intensifica a valorização da vida e de todo o conteúdo humano que as doenças possam expelir para o cotidiano das pessoas. Contudo, as primeiras reações são de adaptação à nova realidade provocada pela mudança da perda do seio e de todas as outras transformações sofridas pelo corpo e pela mente.

Eu tinha de reconstruir uma pessoa que ficou sem alguns pedaços e não estou a falar do meu peito. Havia sido submetida a um processo de muita violência, as drogas do tratamento me jogavam em longos instantes de depressão (...)Quando terminou a quimioterapia, foi como se eu tivesse renascido. (...) Os médicos diziam: 'Você tem de voltar às suas atividades normais'. Impossível, eu estava anormal: no corpo e na cabeça. Tinha de dar-me um tempo para decantar a experiência, digeri-la.

Avaliando os enfrentamentos psico-sociais e o instinto de sobrevivência após a detecção de um tumor, a decisão de se submeter à cirurgia é às vezes irreversível, pois é a única saída para a vida, caso contrário, o câncer se alastra para outras partes do corpo e a conseqüência final será a metástase. Porém, muitas mulheres preferem não realizar a mastectomia por medo da rejeição e a dificuldade de aceitação no meio social perante as outras mulheres, amigas e/ou o parceiro/marido. Isto devido ao fato de a afirmação da feminilidade se concretizar no olhar do outro. Sentir-se bela e atraente é fruto da admiração e aceitação do próximo, e as características que fogem ao padrão de normalidade pertencem ao mundo dos diferentes.

A auto-imagem e a feminilidade estão intrinsecamente ligadas ao mundo do convívio e das relações sociais, e por questões históricas, a mulher não reivindicou seus direitos de igualdade, pois a luta pela sobrevivência acarretou diferentes ligações desta com o universo masculino. Para desenvolver seu papel na sociedade, coube à mulher aceitar as características de um ser atrativo e reprodutivo. Estes são os conceitos que BEAUVOIR (1970) utiliza para explicar a categoria de "segundo sexo" designada às mulheres. "A necessidade biológica desejo sexual e desejo de posteridade -, que coloca o macho sob dependência da fêmea, não libertou socialmente a mulher".

Diante da imposição à mulher de ser atrativo e das características culturais do feminino, o aspecto físico e as cicatrizes da mastectomia trazem a perda da condição social da 
mulher, sendo esta esteticamente bonita quando seu corpo é atraente, e sua realização como mãe é concretizada no ato de parir e amamentar um filho.

Apesar de existir a possibilidade da reconstrução mamária logo em seguida à cirurgia mastectomia, a sensação de artificialidade e agressão ao corpo humano não desaparece; para o uso do silicone, é necessário um constante acompanhamento médico, e depois de alguns anos de utilização, a troca do implante é imprescindível. Outro fator estético importante para a mulher é a perda dos pêlos e cabelos acarretada pela quimioterapia, pois são marcas visivelmente mais aparentes do que as da cirurgia. A desconstrução da identidade pela lacuna concreta da mama é uma resposta ao sentimento original de ausência e castração de um referente identificatório como mulher.
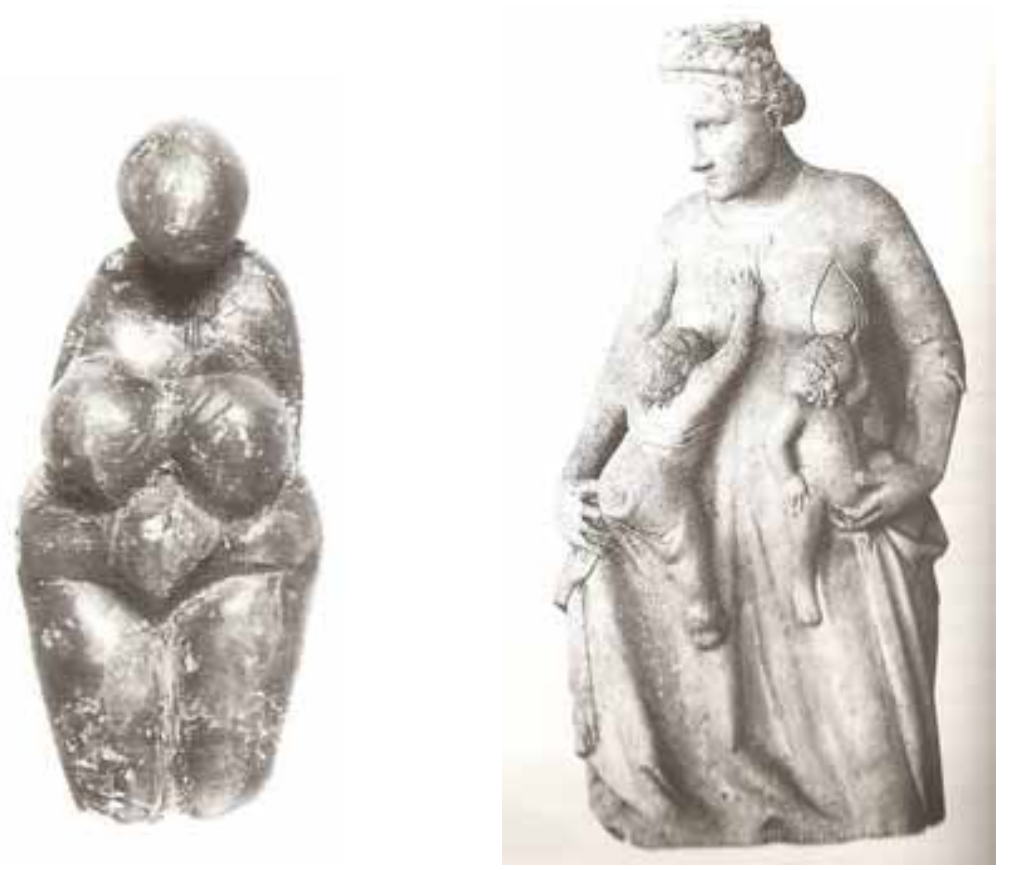

Figuras 2 e 3 - Obras representativas de antigas manifestações artísticas de feminilidade e maternidade - "Venus", de Grimaldi. 23.000 a.C. e "Caridade”, de Tino Camaino - século XIV - Fonte: Yalom, História do Seio, 1997

Durante todas as mudanças corporais enfrentadas pela mulher mastectomizada, o sexo passa a ser uma atividade delicada, exigindo cuidados e compreensão do marido ou parceiro. Normalmente, mulheres solteiras ou viúvas tendem a enfrentar mais tabus na hora de relatar a situação aos homens. Todavia, o que de fato impede a liberação e satisfação sexual da mastectomizada é o seu próprio preconceito e a não aceitação da situação de mutilação.

Se a perda do seio é um tabu para a mulher e considerando a condição de fragilidade física, emocional e psicológica da mastectomizada, a identificação com o médico é uma luz 
na trajetória da erradicação da doença e um passo a mais na decisão da cirurgia. Isso porque o profissional da área já está acostumado com a situação da enfermidade e assim não ocorrerá o olhar do sofrimento, da pena e da discriminação. Também porque grande parte da esperança da recuperação e da eliminação do tumor está na experiência e competência que lhe é atribuída. Zecchin (2004, p.110) descreve que a vulnerabilidade do momento pode ser diminuída se houver confiança na relação médico-paciente.

Como conversar com esta dor? Dor curiosa, pois o câncer é uma doença auto-imune, o que significa uma reação das células contra o próprio tecido. Algo dentro do corpo que age contra os tecidos mas contra si mesmo também, uma representação possível. Não deixa de ser uma máxima da fragilidade e da impotência. Ao mesmo tempo o câncer em si só pode ser retirado pelo médico, ponto em direção à intensidade transferencial a qual já me referi; tal qual a situação do bebê que depende de sua mãe para sobreviver. A paciente está com sua vida, como nos primórdios, na mão de um outro, o médico.

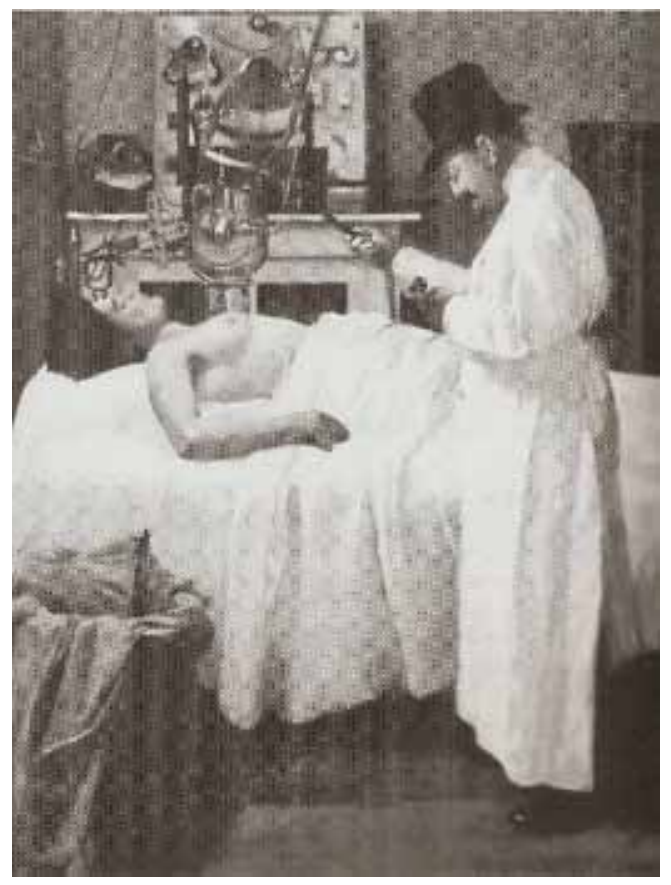

Figura 4 -. "Primeiros tratamentos de raio-X para o cancer de mama", G. Chicot - 1908 Fonte: Yalom, História do Seio, 1997

A foto acima é analisada como um retrato antigo da situação das pacientes do século passado. Primeiramente, o fato de a presença médica ser sempre masculina, e segundo, porque as posições de verticalidade do homem e horizontalidade da mulher corroboravam o caráter de submissão e nervosismo da ocasião. 
Porém, atualmente, mesmo com um relacionamento apropriado, não é possível exigir reações e todas as compreensões de ordem emocional dos profissionais da área médica. Até mesmo por uma questão de compromisso com o trabalho e não interferência nos resultados cirúrgicos, o médico deve se manter preparado para não assumir todas as responsabilidades relacionadas ao diagnóstico biológico do corpo humano. Intensifica-se em dado momento a necessidade da paciente de receber apoio de psicólogos, fisioterapeutas e, dependendo das condições financeiras, acrescenta-se também o respaldo da assistência social.

Porém, ZECCHIN (2004) defende que o sucesso na recuperação da doença está intimamente ligado à união e à não segmentação dos profissionais dos mais variados campos de trabalho. Os estudos médicos, a prevenção e a erradicação do tumor não competem a um único profissional. Permitir que a paciente tenha a possibilidade de escutar diferentes opiniões sobre algo que vai acontecer em seu corpo é uma tarefa que atravessa a situação da doença em si e oferece margem a uma discussão mais global sobre os entraves sociais da mulher.

As cicatrizes de ordem interna possuem um valor representativo significativamente maior do que as marcas da mutilação. O acompanhamento do corpo feminino no caso de um câncer de mama é de vital importância para o resgate da auto-estima e, infelizmente, esta questão permance atrelada às condições socioeconômicas femininas. É neste momento que o atendimento de profissionais multidisciplinares se torna fundamental no desenvolvimento das políticas de saúde para a mulher, acrescentando-se também neste rol de assistência o perfil do comunicador como um agente de divulgação responsável pelos fatos concretos da prevenção e erradicação da doença.

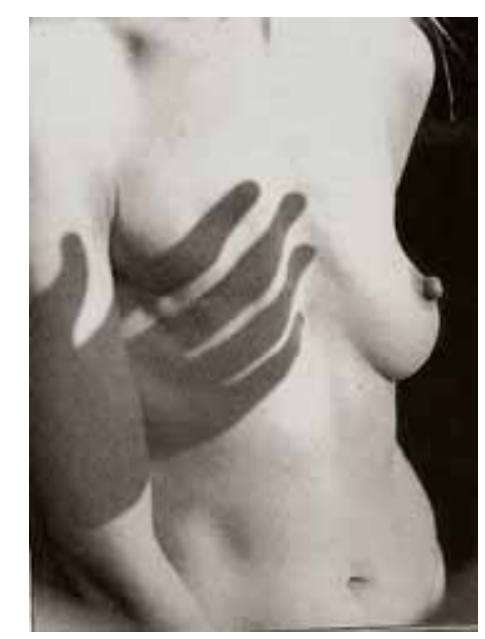

Figura 5 - "The hand”, de Matuschka and Mark Lyon - 1992.

Fonte: Yalom, História do Seio, 1997. 
2.4. Políticas e direitos para o câncer de mama

O câncer de mama é uma doença sem origens totalmente identificáveis, cujos estudos não comprovam com exatidão o surgimento da detecção. Embora se constate que algumas mulheres possuem maior probabilidade de contraí-lo, a preocupação com a sua prevenção é universal, independente de raça, cor ou modo de vida.

Diante da complexidade da doença, torna-se imprescindível a intensificação e democratização da informação, de modo que a sociedade usufrua e possa acompanhar o progresso da medicina, que tem avançado principalmente na área de cirurgia plástica - um fator positivo para a diminuição das marcas da mastectomia. Comparando a cirurgia realizada hoje com a que era feita há algumas décadas atrás, é notável o aprimoramento desta prática.

Poucas mulheres são informadas, mas atualmente, as mastectomizadas possuem direito de comprar um automóvel zero km com câmbio automático e direção hidráulica (estas medidas são necessárias, pois no caso da cirurgia, perde-se parte da força no braço em razão de esvaziamento das glândulas axilares) mais a isenção de impostos, como o IPI - Imposto Sobre Produtos Industrializados, ICMS - Imposto sobre Circulação de Mercadorias e Prestação de Serviços, IPVA - Imposto sobre a Propriedade de Veículos Automotores. Outra medida é a liberação para circulação em dias de rodízio municipal.

Conforme a lei $\mathrm{n}^{0}$ 9.797, de 6 de maio de 1999, o Estado dispõe sobre a obrigatoriedade da cirurgia plástica reparadora da mama pela rede de unidades integrantes do Sistema Único de Saúde - SUS, nos casos de mutilação, decorrentes de tratamento de câncer.

Art. $1^{0}$. As mulheres que sofrerem mutilação total ou parcial de mama, decorrente de utilização de técnica de tratamento de câncer, têm direito a cirurgia plástica reconstrutiva.

Art. $2^{\circ}$. Cabe ao Sistema Único de Saúde - SUS, por meio de sua rede de unidades públicas ou conveniadas, prestar serviço de cirurgia plástica reconstrutiva de mama prevista no art. $1^{\underline{0}}$, utilizando-se de todos os meios e técnicas necessárias. 
Já no âmbito estadual, em São Paulo, segundo o Programa de Cirurgia Plástica Reconstrutiva da Mama, a informação direcionada para as mulheres com câncer de mama deve ser veementemente divulgada, seja no domínio público ou privado.

Art. $4^{\circ}$. O Programa de Cirurgia Plástica Reconstrutiva da Mama será objeto de ampla divulgação no âmbito de todos os serviços de saúde, públicos ou privados.

Parág. $3^{\circ}$ - A Secretaria da Saúde deve envidar esforços para garantir que todos os profissionais da rede pública ou particular, que realizam tratamentos que podem ocasionar a mutilação parcial ou total da mama, recebam orientação sobre a existência do Programa e os locais onde o mesmo se realiza. ${ }^{30}$

Em contraponto a esses avanços e insistindo na necessidade de informação diante da seriedade das implicações decorrentes da doença, é assustador constatar que na década de 70, nos EUA, Segundo Kushner (1981, p.119), as mulheres portadoras de câncer de mama, submetidas a uma mastectomia, chegavam ao hospital para realizar uma biópsia - retirada de um fragmento de tecido do organismo vivo para o exame da natureza das alterações nele existentes - e conforme o tamanho do tumor encontrado, a cirurgia era realizada na hora, sem o conhecimento da paciente. Diversas mulheres acordavam da anestesia sem um de seus seios, sem direito à escolha e muito menos à informação.

Ainda ponderando sobre os avanços nos tratamentos, a adoção da cirurgia mastectomia parcial também é um ponto positivo. Hoje, não é mais necessária a mutilação total do seio. Caso o tumor ainda esteja em fase inicial, é possível realizar cortes parciais no seio, de modo que apenas uma parte tenha que ser reconstruída, ou seja, todo tecido da mama e os nódulos linfáticos da axila são removidos; contudo, os músculos peitorais ficam intactos. Mesmo as mulheres que sofreram cortes ou a retirada dos bicos do seio também podem contar com a reconstrução por meio da retirada de cartilagem de outras partes do corpo.

Todavia, não se pode esquecer que a medicina é uma área em constante atualização. Para salvar vidas ou chegar a um resultado menos doloso na rotina de pacientes, como é o caso das portadoras de câncer de mama, muitas hipóteses foram testadas e aplicadas nessa trajetória de pesquisas e práticas.

Fatos historicamente situados comprovam essa concepção da medicina em relação ao câncer. Para Kushner (1981, p.129 e 130), a cirurgia era essencialmente voltada ao combate

\footnotetext{
${ }^{30}$ Dados provenientes da Assembléia Legislativa do Estado de São Paulo, site: www.al.sp.gov.br
} 
do câncer; mesmo que as probabilidades de desenvolvimento fossem mínimas, a mutilação era a única saída.

\begin{abstract}
Durante décadas, os cirurgiões se recusaram a operar mulheres grávidas ou que estivessem amamentando. Argumentava-se que o câncer de seio é tão bem nutrido por hormônios durante a gravidez que a mulher grávida provavelmente morreria antes de o bebê nascer. (...) Quer o leitor ou a leitora acredite ou não, era uma prática cirúrgica comum (e não há muito tempo atrás), remover o segundo seio junto com o seio canceroso como "profilaxia". Para um cirurgião, talvez faça sentido. Mais ou menos um por cento das pacientes com câncer de seio tem também no outro seio um não detectado. Algumas vezes são até "imagem no espelho", tumores achados exatamente no mesmo lugar em ambos os seios. Além disso, dez por cento das mulheres que tiveram câncer num seio, subseqüentemente desenvolvem câncer no outro seio. Mas o câncer não pode crescer onde não há seio: assim sendo, alguns cirurgiões usavam defender a remoção rotineira do segundo órgão com mastectomia simples enquanto amputavam radicalmente o câncer maligno.
\end{abstract}

As mulheres aprendem sobre auto-exame, biópsia, diferentes tipos de mastectomias, como se estes representassem o fim dos problemas do câncer de mama. $\mathrm{Na}$ verdade, a mastectomia simboliza o início de uma vigilância contínua que envolve a necessidade de exames periódicos. Para um bom acompanhamento do quadro clínico da doença seria de extrema relevância que a mastectomizada tivesse o apoio constante de postos de sáude.

Kushner (1981, p.151) apontou falhas e inadequações nas práticas trabalhistas e de saúde em seu país, os Estados Unidos da América. As discordâncias da autora se reportam às formas de contratação, quando expõe que:

Essa prática não faz sentido de jeito nenhum. Mas é um fato da vida. Contratar alguém que tenha câncer aparentemente traz problemas. Primeiramente, um grande número de firmas têm planos de seguro e de pensão que não cobrirão tais empregados. $\mathrm{O}$ sindicato, se houver, requer que todos os empregados sejam cobertos por quaisquer planos que estejam em vigor, e o resultado é que as firmas simplesmente proíbem a contratação de pessoas que anteriormente tiveram câncer.

A discriminação no emprego também foi uma consequência referente à mastectomia nas últimas décadas. A autora relata um caso divulgado no jornal estadunidense The New York Times, em novembro de 1974, onde uma nota informava que Joyce Arkhust, nascida em Nova York, havia sido recusada em um emprego na ONU - Organização das Nações Unidas porque tinha realizado uma mastectomia em abril de 1973 (KUSHNER, 1981, p.150). 
Seu câncer fora curado, de acordo com o médico dela, mas o departamento pessoal da ONU, onde ela tinha pleiteado um emprego com duração prevista de dois anos, não a contratou. Embora todos que tivessem entrevistado Joyce pensassem que ela estava qualificada, ela não pôde obter a necessária liberação médica: foi informada de que a ONU não contrata pacientes que tiveram câncer enquanto não tiverem passado cinco anos desde seu último tratamento.

Apresentando semelhanças com a realidade norte-americana, acrescidas da lentidão quanto aos seus processos decisórios, a saúde pública no Brasil é uma área que necessita de desburocratização e investimento, sendo ainda necessário constante apoio dos governantes para que os planos não sofram descontinuidade com as mudanças administrativas e econômicas; enfim, o país demanda reorganizações e novas estratégias de políticas públicas. ${ }^{31}$

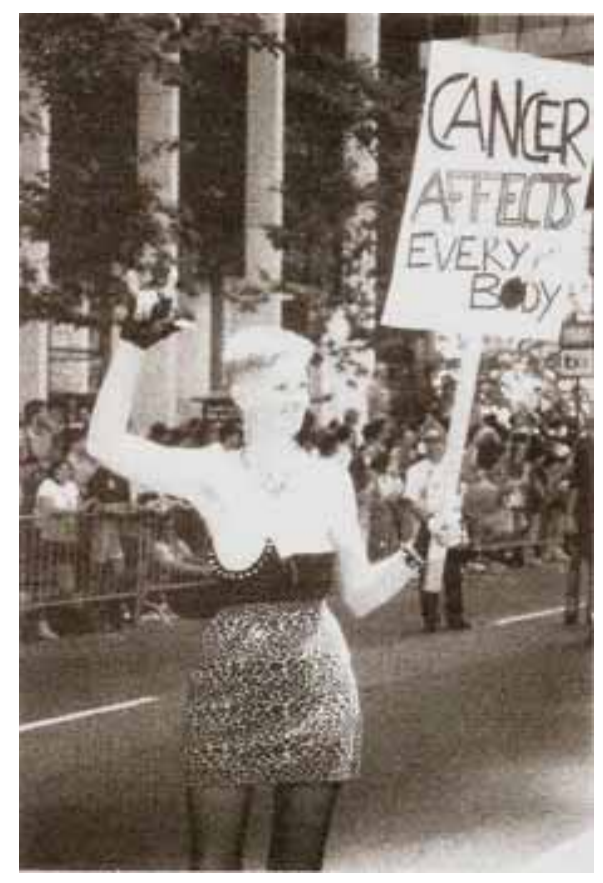

Figura 6 - "Desfile homossexual em São Francisco, EUA", de Reid S. Yalom - 1994

Fonte: Yalom, História do Seio, 1997

31 Nas eleições do Brasil de 2002, mais de 60 empresas que atuam na área de planos de saúde fizeram doações de R\$ 7,2 milhões para campanhas de eleitos e não-eleitos pelo país. Financiaram parte das campanhas de 29 deputados federais e dois senadores. O levantamento das 62 empresas do ramo que financiaram campanhas eleitorais foi divulgado pelos pesquisadores do Centro Brasileiro de Estudos da Saúde, ligados a entidades médicas. Site - http://www.cebes.org.br/ 
As políticas públicas de saúde destinadas exclusivamente ao universo feminino favorecem o desenvolvimento de estudos analíticos sobre o corpo e as suas especificidades. No caso do câncer de mama, as campanhas se caracterizam como pioneiras, cujos resultados tendem a desmistificar e desconstruir a imagem estigmatizada que antigamente conceituava a mulher como simples reprodutora, considerando que há poucos anos atrás, as necessidades de consultas médicas aconteciam somente em casos ligados à gestação e procriação.

Segundo PINOTTI (1998, p. 15), "O sistema tradicional de saúde considera a mulher importante apenas no exercício de sua função reprodutiva, isto é, quando ela está grávida." Apesar disso, a criação de órgãos voltados especificamente à saúde feminina, como o PAISM - Programa de Atenção Integral à Saúde da Mulher, é um avanço na medida em que as características físicas e psicológicas do gênero são reconhecidas como diferentes das masculinas, e o país se aproxima da atual definição da ONU na qual saúde é um bem-estar bio-psico-social.

Tradicionalmente, o sistema de saúde brasileiro tem se voltado para curar doenças nos estágios intermediário e terminal e não para detê-las no início de seu desenvolvimento ou para preveni-las. Não é por acaso que os centros de saúde estão muitas vezes vazios, enquanto os hospitais estão sempre lotados. (...) Por isso, embora haja em praticamente todas as regiões do País oportunidades de prevenção, de diagnóstico e de tratamento eficiente do câncer, a doença está longe de poder ser considerada sob controle. Ainda hoje, a maioria das mulheres desconhece essas oportunidades ou não sabe como chegar a elas. (1998, pp. 109-110)

A saúde pública deveria rever suas concepções e definições de políticas diante da gravidade do problema câncer de mama, uma vez que é muito mais promissor e econômico ao governo investir na conscientização da prevenção de doenças. Nas palavras de PINOTTI (1998, p.5), a educação na área da saúde é uma ferramenta de empoderamento do cidadão, método que além de reduzir futuros gastos, liberta-o da condição de leigo no assunto, fazendo com que o conhecimento seja um aliado na rapidez e funcionalidade das relações estabelecidas nos postos. 
Não existe nada mais importante para a saúde das mulheres do que usufruírem dos mecanismos de detecção e prevenção das doenças e a garantia da preservação de seus direitos, em relação ao sistema público de saúde. Isso não tem acontecido pelas mais diferentes razões, mas, principalmente, pela desestruturação e caotização do sistema público de saúde brasileiro, baseado em um conceito distorcido de uma visão menor do processo de globalização da economia e do neoliberalismo, onde saúde está se tornando cada vez mais uma mercadoria e cada vez menos um direito de sáude.

Desde a criação do SUS e do PAISM, a concepção de independência das práticas de assistência foi colocada em pauta. Tornou-se fundamental ao Brasil assumir, por parte de suas ações inclusivas, o investimento na área de saúde das mulheres e na garantia da preservação de seus direitos. Em suas análises, Denise Garcia (2002, p.104) situa historicamente por que o PAISM não conseguiu se libertar dessas concepções reprodutivistas, ressaltando o fraco investimento financeiro que o impediu de substituir o pronto-atendimento pela qualidade das consultas médicas do serviço público.

\begin{abstract}
A evolução histórica recente do sistema de saúde não se deu no sentido de extensão de uma rede básica regionalizada e hierarquizada, como propunha e necessitava o PAISM, mas predominantemente na direção da extensão do pronto-atendimento médico na rede de saúde pública, com escassa racionalidade epidemiológica e sucateamento dos recursos. No que toca ao trabalho médico, esse movimento correspondeu a uma progressiva especialização e fragmentação, priorizando o setor privado e o consumo de equipamentos de diagnóstico e terapêuticos de alta incorporação tecnológica. Nesse contexto, o PAISM acabou por reduzir-se, no cotidiano do trabalho, a um certo aumento da oferta de assistência gineco-obstétrica, centrando-se, assim, somente em ações dirigidas ao tratamento de patologias do aparelho reprodutor feminino, o que reduziu em muito as suas pretensões iniciais.
\end{abstract}

A pesquisadora analisa sob a ótica geográfico-social uma campanha de prevenção de câncer de colo de útero e de mama realizada na zona leste da cidade de São Paulo, entre os anos de 1994 e 1997, cuja idealização nasceu de movimentos sociais e de grupos de mulheres residentes no município. Sua análise reconhece as iniciativas da sociedade civil e o protagonismo da população como mais eficientes do que as políticas públicas de saúde brasileiras.

Além da defesa da garantia dos direitos da mulher, a campanha analisada por Garcia também obteve um resultado organizativo no que diz respeito aos fatores socioeconômicos. A incorporação de conceitos sobre as relações de gênero no cotidiano dos movimentos sociais torna-se um grande apoio à saúde feminina, pois não desvincula tais questões das 
reivindicações econômicas, trabalhistas e políticas, considerando a emancipação feminina uma união de direitos em todos os aspectos sociais.

Analisando a forte incidência de câncer no Brasil, apenas as funções do SUS não seriam suficientes para o controle necessário. Instituiu-se, conforme a Portaria no 2.439 /GM de 8 de dezembro de 2005, a Política Nacional de Atenção Oncológica ${ }^{32}$, cujos objetivos são: promoção, prevenção, diagnóstico, tratamento, reabilitação e cuidados paliativos com a doença, sendo implantada em todos os Estados da Federação, respeitando as competências das três esferas de gestão.

Conforme a criação da PNAC e considerando a Constituição Federal, em seus artigos 196 a 200 - Leis Orgânicas da Saúde no 8.080, de 19 de setembro de 1990, e no - 8.142, de 28 de dezembro de 1990, é importante para esta pesquisa explicitar alguns artigos, principalmente o primeiro e o segundo, que dizem respeito ao acesso e troca de informações com a sociedade sobre o câncer de mama.

Art. $2^{\circ}$ Estabelecer que a Política Nacional de Atenção Oncológica deve ser organizada de forma articulada com o Ministério da Saúde e com as Secretarias de Saúde dos Estados e Municípios, permitindo:

VII - contribuir para o desenvolvimento de processos e métodos de coleta, análise e organização dos resultados das ações decorrentes da Política Nacional de Atenção Oncológica, permitindo o aprimoramento da gestão e a disseminação das informações;

VIII - promover intercâmbio com outros subsistemas de informações setoriais, implementando e aperfeiçoando permanentemente a produção de dados e a democratização das informações com a perspectiva de usá-las para alimentar estratégias promocionais da saúde;

Art. 3ำ Definir que a Política Nacional de Atenção Oncológica seja constituída a partir dos seguintes componentes fundamentais:

\footnotetext{
${ }^{32}$ Tanto a oncologia como a carcilogia são estudos da medicina relativos a tumores celulares.
} 
VII - Plano de Controle do Tabagismo e outros Fatores de Risco do Câncer do

Colo do Útero e da Mama: deve fazer parte integrante dos Planos Municipais e Estaduais de Saúde.

$\mathrm{X}$ - sistema de informação que possa oferecer ao gestor subsídios para tomada de decisão no processo de planejamento, regulação, avaliação e controle e promover a disseminação da informação. ${ }^{33}$

Por meio da rede oncológica brasileira e do PNAC, o câncer pode ser tratado em hospitais capacitados pelo Ministério da Saúde. Existem as chamadas Unidades de Assistência de Alta Complexidade em Oncologia - UNACOM, que oferecem tratamento dos cânceres mais prevalentes e os Centros de Assistência de Alta Complexidade em Oncologia CACON, com tratamentos para todos os tipos de cânceres.

Porém, a procura desses centros não deve ser o primeiro passo para uma pessoa que suspeita estar com câncer. Primeiramente, é necessário se apresentar nos serviços da rede básica ou da rede hospitalar geral. Caso os exames complementares notifiquem algum conjunto de sinais e sintomas, será imprescindível o apoio da rede oncológica. O câncer é uma doença que possui inúmeros sintomas e acomete diversos órgãos podendo causar confusão por parte dos pacientes. Entretanto, no caso do caso do câncer de mama, existe o auto-exame das mamas que é feito pela própria mulher e pode auxiliar na detecção antecipada da doença.

Segundo a matéria $O$ câncer à margem da política, da revista $\mathrm{ABCâncer}^{34}$, a longa espera da detecção e do tratamento torna-se um elemento agravante para o desenvolvimento da doença. "Atualmente um paciente pode aguardar de seis a oito meses na fila de espera para um exame diagnóstico, em média. Já na fila de espera para estadiamento, onde pode-se conhecer a extensão exata da doença, aguarda-se, em média de quatro a cinco meses." E nas palavras da oncologista entrevistada Nice Yamaguchi, "Era preciso que houvesse uma rota de adiantamento, para ter condições de diagnosticar a doença mais cedo. O paciente espera por no mínimo 10 meses, mas a doença não espera.”

\footnotetext{
${ }^{33}$ Informações provenientes do site do Ministério da Saúde do Brasil - www.saude.gov.br

${ }^{34}$ A revista ABCâncer é uma publicação bimestral da Associação Brasileira do Câncer distribuída gratuitamente em hospitais e centros oncológicos do Brasil. A matéria citada refere-se à edição de outubro/novembro 2006.
} 
Ponderando sobre o tratamento complementar após o diagnóstico do câncer, segundo a Sociedade Brasileira de Radioterapia, cerca de 100 mil pacientes deixam de receber radioterapia por ano em razão das filas, presentes mesmo em grandes centros como o sudeste. Já sobre o assunto formação do profissional de Medicina, todos os entrevistados parecem concordar que a área necessita de uma revisão: "Entre as cerca de 120 faculdades de Medicina do país, menos de $20 \%$ têm a disciplina Oncologia entre as obrigatórias". Essa deficiência é mais um significante fator a ser considerado na dificuldade dos médicos para diagnosticarem rapidamente a doença.

Outro dado que muito dificulta a vida dos portadores de câncer é o alto custo da medicação necessária para tratamento. Este é um dos fatores de atrito entre laboratórios, governo e pacientes, criando uma situação delicada e paradoxal. Se por um lado existem as falhas, filas e carências nacionais para o acesso a remédios, por outro existe a Constituição Brasileira que prevê acesso universal à saúde como um direito de todos e dever do Estado, assegurando, inclusive, o fornecimento de medicamentos mais caros.

Para tal problemática, entrou em vigor, no ano de 1998, a Política Nacional de Medicamentos, cujo objetivo é garantir segurança, eficácia e qualidade dos remédios, a promoção do uso racional e o acesso da população àqueles considerados essenciais entendidos como indispensáveis para atender à maioria dos problemas de saúde da população. Os produtos da Relação Nacional de Medicamentos Essenciais - RENAME devem estar continuamente disponíveis à sociedade e em constante processo de atualização. Enfatiza-se o conjunto de medicamentos necessários às doenças mais comuns segundo critério epidemiológico.

Quanto aos medicamentos de alto custo, como é o caso do câncer, o processo de recebimento é diferente, fora do âmbito das farmácias do SUS. Todo o processo está ligado aos cerca de 300 estabelecimentos de saúde prestadores de assistência oncológica espalhados pelos 26 Estados, em 128 municípios. A maioria deles é hospital geral com distinguida capacidade de prestar atendimento de alta complexidade e alguns são hospitais especializados em câncer, os CACON e UNACOM. 
Segundo o Inca, em resumo, são esses os passos necessários para um paciente obter medicamento para câncer no SUS:

1- O paciente é atendido por médico em hospital ou clínica isolada de quimioterapia cadastrada no SUS para atendimento de pacientes com câncer.

2- O médico avalia e prescreve o tratamento indicado, conforme as condutas adotadas nesse hospital ou clínica.

3- O paciente é submetido ao tratamento indicado, inclusive recebe do hospital ou clínica os quimioterápicos que irá tomar em casa, por via oral.

4- O médico preenche o laudo de solicitação de autorização para cobrança do procedimento no SUS e o encaminha ao gestor local, que pode ser uma secretaria municipal ou estadual de saúde.

5- O gestor autoriza a cobrança conforme as normas vigentes do Ministério da Saúde e fornece ao hospital ou clínica um número de APAC. ${ }^{35}$

6- O hospital ou clínica cobra do SUS no final do mês o valor mensal do respectivo tratamento.

7- O SUS paga ao hospital ou clínica o valor tabelado relativo ao procedimento.

Por pressões de laboratórios e grupos de pacientes liderados por organizações da sociedade civil, existe nesse processo de tratamentos e medicações uma demanda por remédios excepcionais - de valores extremamente caros. Conforme a entrevista divulgada ${ }^{36}$ com Celso Rotstein, oncologista clínico do Inca, os aspectos da eqüidade costumam ser ignorados. "Se você incluir na lista de medicamentos excepcionais um remédio que custa $\mathrm{R} \$$ 20 mil a caixa para câncer de cólon e se temos 30 mil casos por ano de câncer de cólon, devem existir recursos para fornecer o medicamento aos 30 mil pacientes, ou seja, pelo menos R\$ 60 milhões a mais no orçamento." Rotstein então finaliza: "Não é isso, porém o que acontece. Na prática, remédios são incluídos sem que haja lastros para fornecê-los a todos e só aqueles bem informados e capazes de recorrer à Justiça conseguem obtê-los".

\footnotetext{
${ }^{35}$ APAC corresponde ao documento de Autorização de Procedimentos de Alta Complexidade/Custo do Ministério da Saúde do Brasil.

${ }^{36}$ Matéria Vale a pena?, Revista ABCâncer de março de 2007.
} 
Há de se levar em conta dois obstáculos para o recebimento desses medicamentos. Primeiro, o período de consentimento para a fabricação, "o tempo para a aprovação de um remédio, que raramente era menor do que seis anos, hoje já chegou a menos de três anos”, relatou Rotstein. Segundo, aprovado o medicamento, o laboratório responsável pela produção encaminha um pedido de comercialização à Agência Nacional de Vigilância Sanitária ANVISA, com uma sugestão de preço. Ao final, começa então o debate polêmico sobre a viabilidade econômica do remédio, podendo, oportunamente, em altíssimo grau, ser finalizado igualmente ao caso ocorrido em maio de 2007, quando o governo brasileiro quebrou a patente de um medicamento usado no combate ao vírus HIV. ${ }^{37}$

Ponderando sobre todos os motivos relacionados às questões do câncer, desde os políticos até o aumento das incidências, cada vez mais a expectativa pela diminuição dos números de casos de portadores da doença está na autodetecção ou na alternância dos hábitos de vida da pessoa. Para um câncer de pele condena-se a massiva exposição à luz solar; para o de pulmão, o vício do tabagismo e para o câncer de mama, aposta-se no auto-exame das mamas.

Essa condição do indivíduo de ser responsável pelas suas enfermidades é discutida por alguns estudiosos que condenam o peso e a transferência da culpa pela aquisição do câncer. A publicidade, quando não bem trabalhada, pode também ajudar a tornar uma advertência em responsabilidade pessoal.

Nas palavras de José Gomes Temporão (1986, p.147), as emissões das mensagens públicas de prevenção do câncer individualizam e restringem o processo da doença ao cidadão.

\footnotetext{
São comuns principalmente veiculadas pelos jornais, matérias "preventivistas". A Sociedade Brasileira de Cancerologia é freqüentadora assídua dos jornais, com matéria em que alerta o leitor para os perigos do câncer e como proceder para se "proteger". Ou seja, de início individualiza todo o processo de produção dessas doenças e coloca como de responsabilidade do indivíduo assumir um risco maior ou menor em adoecer.
}

\footnotetext{
${ }^{37}$ No dia 04/05/2007, por meio de decreto com licença compulsória, foi assinado pelo presidente Luiz Inácio Lula da Silva a quebra da patente do medicamento Efavirenz, produzido pelo laboratório norte-americano Merck Sharp \& Dohme, usado no combate ao vírus HIV. Anteriores negociações para a redução do preço do comprimido (US\$ 1,59) eram feitas desde 2006. No entanto, a proposta do laboratório, de uma redução de $30 \%$ do valor, foi considerada insatisfatória pelo governo, que pode importar medicamento similar por US\$ 0,45 produzido na Índia.
} 


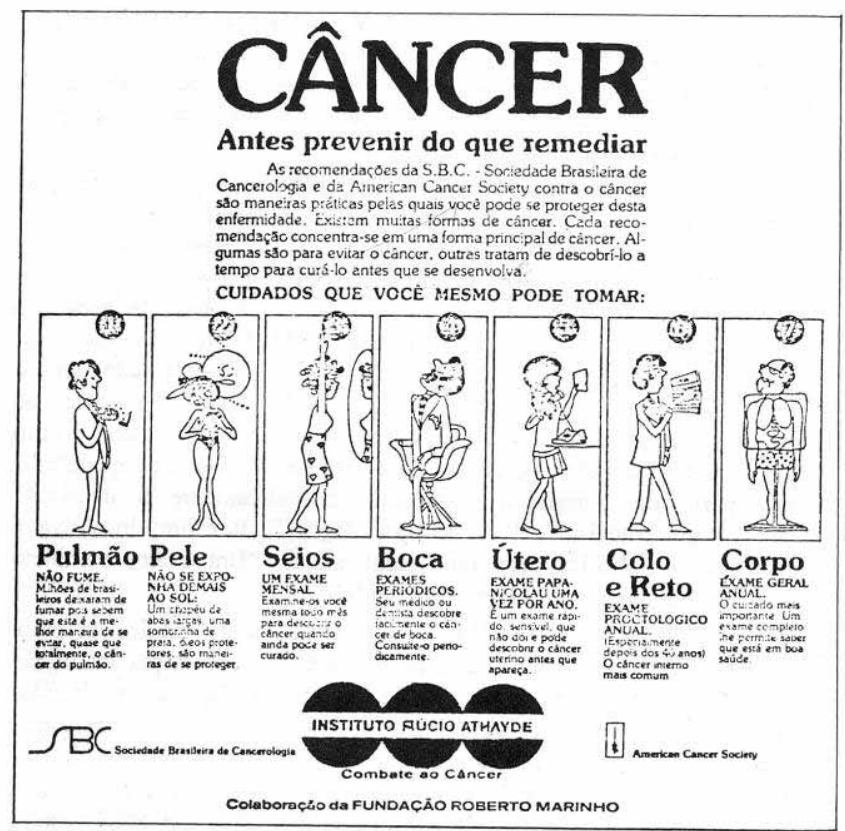

Figura 7 - Propaganda divulgada no jornal O Globo em 24/11/1982

Fonte: TEMPORÃO, A propaganda de medicamentos e o mito da saúde, 1986

As questões da responsabilidade do auto-exame e da culpabilidade da contração ou da detecção tardia de um câncer de mama serão novamente comentadas no capítulo IV, cujo teor se refere à análise da publicidade relacionada à doença. Contudo, há outra grande chance de detecção precoce e erradicação do tumor por meio da utilização do exame de mamografia radiografia especial feita em aparelhos específicos com a finalidade de detectar qualquer alteração nas mamas. Todavia, a mamografia no Brasil ainda permanece como um recurso inacessível para as classes econômicas menos privilegiadas.

Segundo informou a assessoria de imprensa da ANVISA, "O SUS realizou 2,6 milhões de mamografias somente em 2006. Cerca de 50 mil desses exames indicaram novos casos de câncer de mama, de acordo com dados do Inca. Segundo o instituto, a detecção precoce da doença reduz em até 35\% a possibilidade de morte (...) calcula que são necessárias cerca de 4,5 milhões de mamografias por ano para cobertura de 75\% das mulheres consideradas como público-alvo do rastreamento populacional do câncer de mama. Fazem parte desse grupo mulheres acima de 35 anos e com histórico de câncer na família.”

Contudo, por intermédio da assessoria de comunicação da Universidade de Brasília, divulgou-se um texto resumido da pesquisa de doutorado da médica Ana Maria Costa, 
intitulada Atenção Integral à Saúde das Mulheres: Quo Vadis? Uma Avaliação da Integralidade na Atenção à Saúde das Mulheres no Brasil (2005). Sua crítica está estruturada nos recursos insuficientemente distribuídos das regiões de atendimento do SUS. ${ }^{38}$

A pesquisa consistiu em analisar dados estimados para 5.507 municípios brasileiros por meio de uma amostra na qual se realizaram 627 entrevistas com os gestores das secretarias municipais de saúde entre o último trimestre de 2003 e o primeiro de 2004. Costa descobriu que quanto menor o município, menor é o acesso a serviços prestados, sendo que em alguns casos, consta a inexistência total de atendimentos gerais, clínicos e especializados.

\begin{tabular}{|c|c|c|c|c|c|}
\hline \multicolumn{6}{|c|}{ MAPA DA EXCLUSÃO NO SUS } \\
\hline $\begin{array}{c}\text { Tamanho } \\
\text { do } \\
\text { Município }\end{array}$ & $\begin{array}{l}\text { I ntegral } \\
\text { Plus }\end{array}$ & $\begin{array}{l}\text { Semi- } \\
\text { I ntegral }\end{array}$ & $\begin{array}{c}\text { Atenção } \\
\text { Básica }\end{array}$ & $\begin{array}{l}\text { Materno- } \\
\text { I nfantil }\end{array}$ & $\begin{array}{l}\text { Municípios } \\
\text { Excluídos }\end{array}$ \\
\hline $\begin{array}{l}\text { Até } 5 \text { mil } \\
\text { hab }\end{array}$ & - & - & $14,6 \%$ & $35,8 \%$ & $49,6 \%$ \\
\hline $\begin{array}{l}5.001 \mathrm{mil} \mathrm{a} \\
10 \mathrm{mil}\end{array}$ & - & $0,7 \%$ & $14,1 \%$ & $31,3 \%$ & $53,9 \%$ \\
\hline $\begin{array}{l}10.001 \mathrm{mil} \mathrm{a} \\
20 \mathrm{mil}\end{array}$ & - & $1,9 \%$ & $24,3 \%$ & $21,6 \%$ & $52,2 \%$ \\
\hline $\begin{array}{l}20.001 \mathrm{mil} \\
\text { a } 50 \mathrm{mil}\end{array}$ & - & $2,7 \%$ & $17,3 \%$ & $25,6 \%$ & $54,3 \%$ \\
\hline $\begin{array}{l}50.001 \mathrm{mil} \\
\text { e mais }\end{array}$ & $1,7 \%$ & $8,4 \%$ & $23,7 \%$ & $23,9 \%$ & $42,4 \%$ \\
\hline Total & $0,2 \%$ & $1,9 \%$ & $18,2 \%$ & $28,3 \%$ & $51,4 \%$ \\
\hline
\end{tabular}

Tabela 4 - Uma Avaliação da Integralidade na Atenção à Saúde das Mulheres no Brasil, 2005

Fonte: Atenção Integral à Saúde das Mulheres: Quo Vadis?

Suas conclusões foram insatisfatórias para a rede oncológica nacional quanto à diversidade de etnias e condição social das brasileiras. Quase 91\% dos municípios não incluem nos programas de saúde atenção às negras, 91\% não possuem programas voltados

\footnotetext{
${ }^{38} \mathrm{http}: / /$ www.unb.br/acs/bcopauta/saudefeminina $7 . h t m$
} 
para as indígenas, 56\% não incluem programas para as habitantes da zona rural e $85 \%$ não incluem as mulheres assentadas nos programas de saúde. Nessa linha de escassos acessos à saúde feminina, os dados de mamografia confirmam a tendência: $81 \%$ das mulheres não realizam o exame.

Dados oficiais do Datasus, departamento de informática responsável pelo banco de dados do Sistema Único de Saúde, confirmam a centralização dos aparelhos de mamografias no sul e sudeste do país e, conseqüentemente, a capacidade de produção de exames.

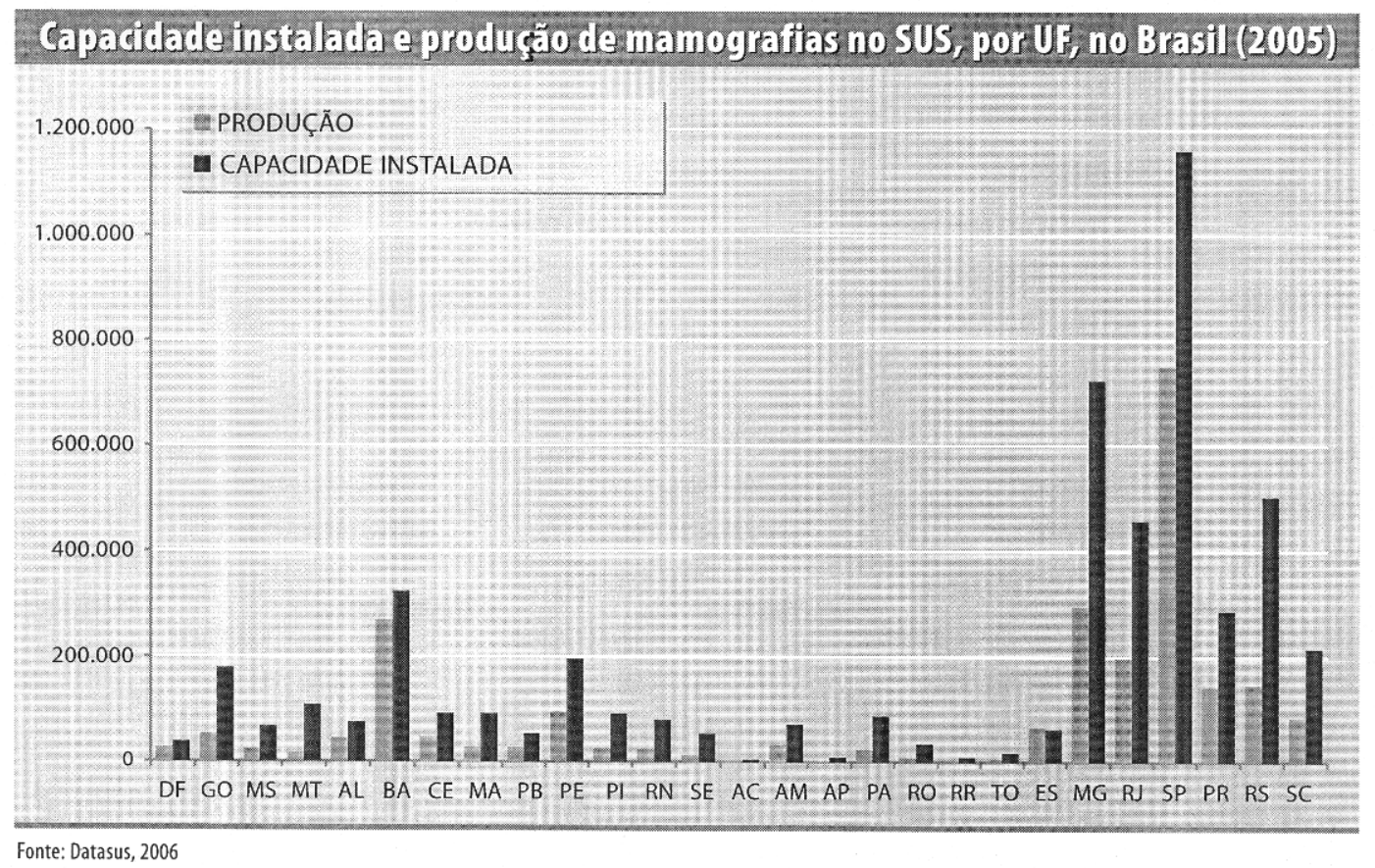

Tabela 5 - Capacidade instalada e produção de mamógrafos no SUS, por UF, no Brasil 2005

Fonte Datasus, 2006 


\begin{tabular}{|c|c|c|c|c|c|}
\hline \multicolumn{6}{|c|}{$\begin{array}{c}\text { Potencial de produção de mamografias, número de mamógrafos } \\
\text { e população feminina, por regíăo, no Brasil (2006) }\end{array}$} \\
\hline \multirow[b]{2}{*}{ Regliso } & \multicolumn{2}{|c|}{ Populaçąo feminina - 2006 } & \multirow[b]{2}{*}{$\begin{array}{l}\text { Mamografos } \\
\text { 5us em uso }\end{array}$} & \multicolumn{2}{|c|}{ Produça de mamografia } \\
\hline & $\begin{array}{l}\text { Risco } \\
\text { elevado: }\end{array}$ & 40 a 49 anos*t 50 a 69 anos** & & $\begin{array}{l}\text { Capacidade } \\
\text { instalada }=0 \%\end{array}$ & $\begin{array}{l}\text { Cohertura } 50 \% \\
\text { populassosalvo }\end{array}$ \\
\hline Centro-Oeste & 2.136 & $118.426 \quad 35.050$ & 94 & 391.040 & 77.806 \\
\hline Nordeste & $B 4.480$ & $413.293 \quad 1.531 .777$ & $254=$ & 1.056 .640 & 1.014 .775 \\
\hline Norte & 18.766 & $103.429=305.998$ & 55 & 228.800 & 214.097 \\
\hline Sudeste: & 158.039 & $828.889 \quad 2790.425$ & 578 & 2.404 .480 & 1.888 .677 \\
\hline Sul $=$ & 53.904 & $281.818 \quad 957.621$ & 242 & 1.006 .720 & 646.672 \\
\hline Brasil $=$ & 317.325 & $\begin{array}{l}1.745 .855 \quad 5,620,871 \\
\end{array}$ & 1.223 & 5.087 .680 & 3.842 .027 \\
\hline \multicolumn{6}{|c|}{ Fente: Datastr, 2006} \\
\hline \multicolumn{6}{|c|}{ 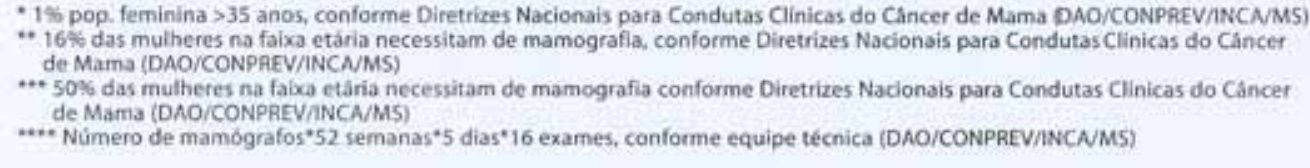 } \\
\hline
\end{tabular}

Tabela 6 - Potencial de Produção de mamografias, número de mamógrafos e população feminina, por região, no Brasil, 2006 - Fonte Datasus - 2006

Outros dados também importantes na divulgação das mamografias foram produzidos pelo Instituto Brasileiro de Geografia e Estatística - IBGE, no relatório Acesso e Utilização de Serviços de Saúde, segundo uma coleta de dados por amostras de domicílios realizada em 2003. O resultado anunciou primeiramente que aproximadamente $30 \%$ dos brasileiros são portadores de doenças crônicas - nesta classificação pode-se incluir o câncer de mama. Em segundo lugar, metade das mulheres do nosso país com mais de 50 anos jamais foi submetida a uma mamografia. Por último, a proporção de mulheres com mais de 25 anos que nunca examinaram a mama também é alta, 57,3\%; já as que não fizeram o exame clínico das mamas, $36,4 \%$.

Sobre tais dados, a matéria ${ }^{39} 1 / 3$ das brasileiras nunca examinou a mama destaca a frase de profissionais do Inca quando perguntados sobre a pesquisa do IBGE: "Ainda não temos estrutura suficiente para chamar todas as mulheres, incluindo as que nunca apresentaram sintomas, para fazerem exame e receberem o tratamento adequado, mas o Ministério da Saúde está se estruturando para isso. A gente pretende que até 2007 o SUS consiga oferecer para toda a população de mulheres a mamografia e encaminhar tratamento adequado para as que necessitem".

\footnotetext{
${ }^{39}$ Jornal Folha de São Paulo, em 26 de maio de 2005.
} 


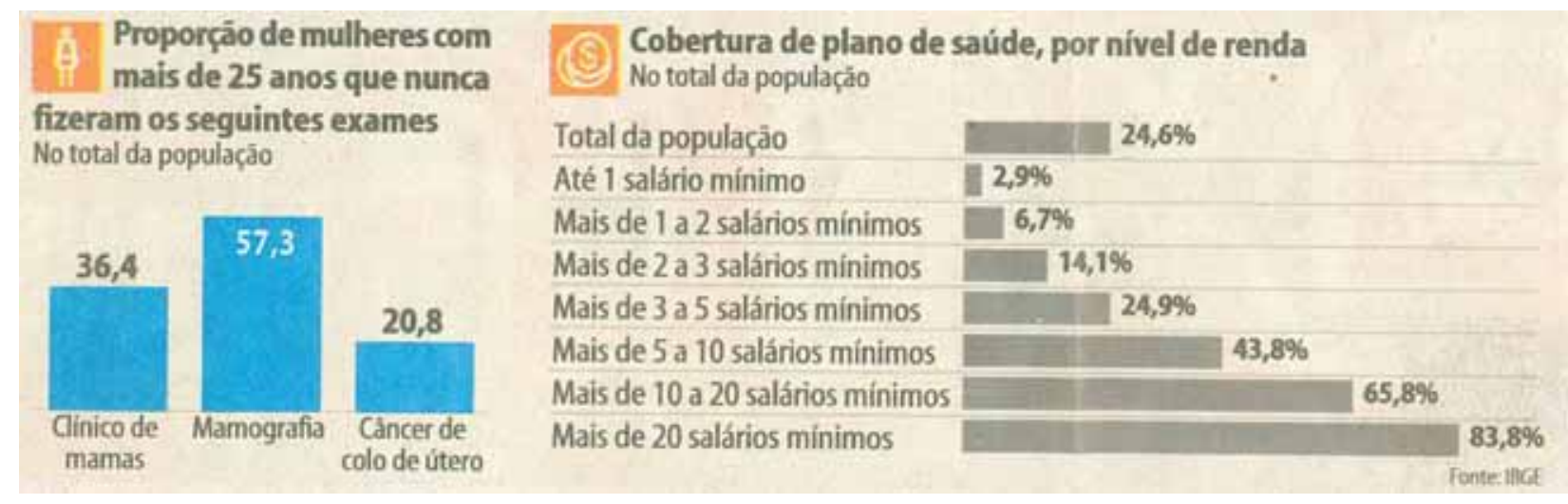

Gráfico 7 - Proporção de mulheres com mais de 25 anos que nunca fizeram exames de mamas e de colo de útero

Gráfico 8 - cobertura de plano de saúde por nível de renda

Fonte: IBGE - Acesso e Utilização de Serviços de Saúde, 2005

Outro alerta está presente no site da Taps - Temas Atuais na Promoção da Saúde ${ }^{40}$, debatido por Diana Hunt, formada em tecnologia radiológica pela Universidade da Califórnia, UCLA. Suas palavras condenam a exibição pela televisão americana de uma propaganda para jovens que planejam fazer uma mamografia, mas estão sempre muito ocupadas. O narrador do filme comenta a necessidade de achar tempo para o exame "porque a mamografia detecta tumores e salva vidas - até 91\%”. Porém, tudo estaria correto se não fosse o final do vídeo, cujas características se assemelham a um anúncio de saúde pública, mas o que aparece é o logotipo da General Electric - empresa fabricante de aparelhos de mamografia.

A crítica de Hunt é sobre a inversão dos papéis sociais, principalmente a ausência do profissional da área de saúde em troca da incitação ao consumo desnecessário de radiografias. “O exame foi criado para confirmar ou descartar o diagnóstico médico. Entretanto, tornou-se uma máquina de fabricar dinheiro, usado em mulheres saudáveis que não apresentam qualquer sintoma de doença da mama."

Se por um lado existe a carência de mamógrafos e a necessidade feminina de prevenção do câncer de mama, por outro, há a alta dose de radiação a que a mulher se expõe durante a realização do exame, cuja necessidade para mulheres jovens ainda não é oportuna. Além do mais, a referida propaganda pode induzir a uma grande perda de tempo por meio de

${ }^{40}$ www.taps.org.br 
uma tentativa ineficaz de ultrapassar os primeiros sinais da doença diagnosticados no autoexame e no exame clínico das mamas, ou seja, a mamografia é aconselhada somente em casos de recomendação médica.

Concomitantemente aos exemplos acima citados, existem muitas outras mensagens comunicativas sobre câncer de mama, passíveis de análises críticas no estudo dos meios, com uma diversidade de frases, palavras, slogans, imagem, entre outros elementos corroborantes de estigmas sociais, desenvolvidos por linguagens metafóricas e influentes nas realidades culturais estabelecidas.

Da realidade da doença surge o processo de criação das campanhas de prevenção que visam despertar interesse no maior número possível de pessoas. No caso do câncer de mama, a persuasão se caracteriza como pioneira na área da saúde feminina, pois assume as especificidades do corpo da mulher, desconsiderando o antigo padrão exclusivo aos assuntos reprodutivos. Todavia, considerar uma doença como um fator positivo para as mulheres terem acesso às consultas médicas é uma emancipação às avessas dentro da contextualização das conquistas de gênero.

O auto-exame, a mamografia e o exame clínico das mamas demonstram-se como etapas inerentes ao processo de reconhecimento de direitos da saúde pública feminina, cujas práticas deveriam ser realizadas por todas as mulheres, tendo ou não o diagnóstico da doença. Os índices de incidência aumentam, as políticas tornam-se estratificadas e o diagnóstico da doença é universal. Nesse cenário carente de informações, o câncer de mama torna-se objeto das iniciativas da comunicação de massa realizadas por meio de campanhas preventivas, podendo assumir proporções educativas, reivindicativas, colaborando com o processo de empoderamento histórico feminino. 


\section{Capítulo III}

Semiótica e a campanha do IBCC 


\section{1 - Referencial teórico para a análise semiótica}

O homem é um ser que criou a si próprio ao criar uma linguagem.

Octavio Paz

O estudo epistemológico da semiótica abrange desde o interesse da Filosofia ao campo da Comunicação, definindo-se, entre outras análises, como uma investigação da descrição dos fenômenos transformados em linguagem na qual saberes distintos se apropriam da ciência lógica do estudo dos signos para entender a realidade humana com todos os seus referenciais simbólicos. Nesse campo cuja meta é decifrar, seus estudos têm por base aplicar conceitos da fenomenologia, ponderando sobre os processos históricos e culturais.

$\mathrm{Na}$ análise adotada nesta pesquisa, utilizou-se a linha semiótica Peirceana, que tem sua base nos estudos de Charles Sanders Peirce (1839-1914), com referências ao seu conceito da tríade dos signos. ${ }^{41}$ Os fundamentos e representações interpretativas são estudados a fim de entender as noções de produção de significados e, conseqüentemente, da semiose comunicativa e publicitária. Santaella (2006 p. 51) afirma que:

Diante de qualquer fenômeno, isto é para conhecer e compreender qualquer coisa, a consciência produz um signo, ou seja, um pensamento como mediação irrecusável entre nós e os fenômenos. E isto, já ao nível do que chamamos de percepção. Perceber não é senão traduzir um objeto de percepção em um julgamento de percepção, ou melhor, é interpor uma camada interpretativa entre a consciência e o que é percebido.

TEIXEIRA COELHO NETTO, ao explicar a semiótica Peirceana, define o conceito de signo e de suas unidades formadoras de uma relação triádica da seguinte maneira:

Um signo (ou um representamen), para Peirce, é aquilo que sob algum aspecto representa algo para alguém. Dirigindo-se a essa pessoa, esse primeiro signo criará na mente (ou semiose) dessa pessoa um signo equivalente a si mesmo, ou eventualmente, um signo mais desenvolvido. Este segundo signo criado na mente do receptor recebe a designação de interpretante (que não é o intérprete), e a coisa representada é conhecida pela designação de objeto. (1980: p. 56)

\footnotetext{
41 Além da semiótica Peirceana há outras correntes de estudos sobre a natureza dos signos. As mais recorrentes atualmente são semiótica greimasiana, de Algidras Julien Greimas (1917-1992) e a semiótica da cultura, de tradição russa, com seus precursores Mikhail Bakhtine (1895-1975) e Roman Jakobson (1896-1982)
} 


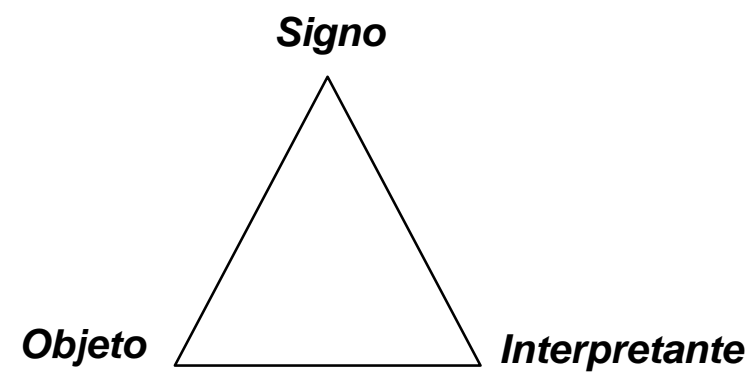

Figura 8 - Elementos da tríade semiótica

$\mathrm{Na}$ investigação para um melhor entendimento do conceito de objeto, há que se levar em consideração seus dois tipos existentes: o imediato e o dinâmico, cujas naturezas são diferentes, dependendo de o signo ser um ícone, um índice ou símbolo. Em termos gerais, o imediato é tal como está apresentado no signo e o dinâmico é o que está fora do signo.

Um dos pontos-chave dessa ciência dos signos é a capacidade de categorização dos seus diferentes significados, pois, sendo considerados signos palavras, sons, símbolos, índices, entre outros, com cadeias de representações infinitas, a semiótica torna-se uma teoria básica para a compreensão da heterogeneidade nos processos de transmissão dos códigos humanos e suas transformações.

\footnotetext{
O longo curso do tempo (the long run, diria Peirce) sempre demonstrará que aquilo que foi tomado como completo não passava de apenas um dos aspectos parciais do objeto, visto que este, na sua inteireza ou totalidade não pode ser capturado nas malhas dos signos. Por mais que a cadeia sígnica cresça, o objeto é aquilo que nela sempre volta a insistir porque resiste na sua diversidade. (Santaella, 2004:31)
}

SANTAELLA (2006: p. 25) há anos decifra e traduz a vasta obra de Peirce, em boa parte ainda inédita. "O que Peirce na realidade postulava, como base do seu pensamento era a teoria do crescimento contínuo no universo e na mente humana. ' $O$ universo está em expansão' dizia ele, 'onde mais poderia ele crescer senão na cabeça dos homens?"

Qualquer coisa que decorra do universo humano produz um efeito na mente, que é o signo. Este por sua vez se refere a um segundo elemento, o objeto, algo visto, palpável, descritível ou sensitivo que só aparece num momento secundário. A precedência lógica é do signo, mas a anteposição real é do objeto. Sendo assim, somos seres primeiramente decifradores de signos, para moldarmos nossa percepção e, por última conseqüência, nossas 
atitudes. Para a autora, "é preciso levar em conta que o efeito que a mente produz não precisa ser necessariamente racional. Pode ser da ordem de uma reação puramente física, ou então, pode ser um mero sentimento com toda a evanescência que é própria de um sentimento."

Para Peirce, existem três distintas categorias do pensamento e da natureza, afirmando que a vida se desenvolve por meio da interação dialética entre a eventualidade e o desígnio; sendo assim, o homem significa tudo o que o cerca numa concepção triádica: Primeiridade, Secundidade e Terceiridade. De um modo mais simples e geral, é possível entendê-las segundo a explicação de Santaella:

A $1^{\mathrm{a}}$. corresponde ao acaso, originalidade irresponsável e livre, variação espontânea; a $2^{\mathrm{a}}$. corresponde à ação e reação dos fatos concretos, existentes e reais, enquanto, a $3^{\mathrm{a}}$. categoria diz respeito à mediação ou processo, crescimento contínuo e devir sempre possível pela aquisição de novos hábitos. O $3^{\circ}$ pressupões o $2^{\circ} ;$ o $2^{\circ}$ pressupõe o $1^{\circ}$; o $1^{\circ}$ é livre. Qualquer relação a três é uma complexidade de tríades. (2006, p.39)

A Primeiridade é a qualidade da consciência imediata; refere-se a tudo o que está imediatamente presente na mente no momento presente de uma primeira análise. Algo primeiramente original, espontâneo e livre, precedente de toda síntese e diferenciação. A Secundidade se define nas reações em relação ao universo, a corporificação material da leitura dos signos, a discriminação. Já a Terceiridade corresponde à camada de inteligibilidade por meio da qual se interpreta o mundo; é a fase da generalização.

$\mathrm{Na}$ teoria Peirceana, existem também três tipos de signos. O ícone, uma representação de proximidade sensorial ou emotiva entre o signo, uma reprodução do objeto, como por exemplo: os bonecos e desenhos ou as fotografias e pinturas. O índice é a significação de um todo obtido pela pré-experiência subjetiva ou pelo legado cultural que determina conclusões, por exemplo: onde há fumaça, logo há fogo. É um sinal, e nesse sentido, estabelece uma relação de causa e efeito. Já o símbolo estabelece uma relação convencionada; é estritamente utilizado para representar algo entre o signo e o objeto, por exemplo: o termo cadeira. 
Concluindo: se o ícone tende a romper a continuidade do processo abstrativo, porque mantém o interpretante a nível de primeiridade, isto é, na ebulição das conjecturas e na correlação das hipóteses (fonte de todas as descobertas); se o índice faz parar o processo interpretativo no nível energético de uma ação como resposta ou de um pensamento puramente constatativo; o símbolo por sua vez, faz deslanchar a remessa de signo a signo, remessa esta que só não é infinita, porque nosso pensamento, de uma forma ou de outra, em maior ou menor grau, está inexoravelmente preso aos limites da abóboda ideológica, ou seja, das representações de mundo que nossa historicidade nos impõe. (2006: p. 68 e 69)

A princípio, a interpretação da natureza humana e o processo mental que ocorre na percepção do indivíduo, quando iniciada a recepção das mensagens comunicativas até a formação de suas atitudes, é um estudo semiótico. Ao se analisar por meio da capacidade contemplativa um determinado signo para se chegar às suas cadeias de representações, é necessário desmembrar primeiro a cadeia sígnica. Feito esse exercício, surgem as noções de segmentação e significação e as diferenças que convergem para o estado de observação (secundidade) e generalização (terceiridade) dos signos.

A primeira consideração da semiótica adaptada ao campo da comunicação é a capacidade do indivíduo de contemplação, distinção e generalização do signo estudado. Essas são as atividades iniciais de desenvoltura para um olhar capacitado dos referenciais estudados, sendo que, quando assumida a prática dessas três capacidades, é possível entender o signo de maneira mais abrangente. Segundo PEREZ (2004, p.150): "Quando percebemos diferenças saímos do estado contemplativo e entramos no estado de observação, direção guiada a um fim. A generalização está ligada à aptidão de disseminar as observações feitas no signo e estendê-las em categorias globalizantes."

Diante de qualquer fenômeno, perante o conhecimento e compreensão de qualquer ocorrência, a consciência produz um signo, ou seja, um pensamento como mediação entre o indivíduo e os acontecimentos. Pode-se denominar essa prática de percepção a tradução de uma camada interpretativa entre a consciência e o que é percebido.

Digamos então para os propósitos da lógica, qualquer coisa deve ser classificada sob a espécie da percepção quando, num conteúdo qualitativo positivo, forçar-se sobre nosso conhecimento sem qualquer razão. Haverá um campo mais vasto de coisas que compartilham o olhar da percepção, se houver qualquer material cognitivo que exerça uma força sobre nós, tendendo a nós fazer reconhecê-lo, sem qualquer razão adequada. (Santaella: 1998, p. 57 e 61) 
$\mathrm{Na}$ visão Peirceana de percepção, existe a criação de uma teoria triádica sob dominância da secundidade, ou a segunda categoria fenomenológica que diz respeito à reação e interação do indivíduo com seu signo. Por isso, para Peirce, a percepção está em constante interação com a ação e memória.

Nessa linha de raciocínio, para Santaella (1998), Peirce conseguiu ir além da evidência dualista de percepção. Primeiro, porque ele não concebia a separação entre percepção e conhecimento, pois acreditava que toda cognição começava na percepção e terminava na ação deliberada. Segundo, porque tanto a cognição como a percepção seriam inseparáveis das linguagens através das quais o homem pensa, age e se comunica. Ou seja, a partir dessas afirmações, entende-se que a teoria Peirceana da percepção possui total respaldo na sua teoria geral dos signos e vice-versa, explicando logicamente os fundamentos das significações humanas por uma inteligência científica. Em suas afirmações:

\begin{abstract}
Penso que a teoria da percepção Peirceana tem um grande papel a desempenhar para estabelecer a ponte necessária entre as pesquisas mais empíricas e os fundamentos filosóficos. Isso só lhe foi possível porque ele foi o primeiro filósofo, também lógico e cientista, a trabalhar diretamente sobre a ponte de ligação entre os fundamentos e a empiria, ponte esta que só pode ser encontrada na linguagem ou universo dos signos. De fato, é naquilo que diz respeito especificamente à percepção que a afirmação acima soa ainda mais provavelmente verdadeira, visto que são os signos, é a linguagem a única e grande forma de síntese de que dispomos para a ligação entre o exterior e o interior, entre mundo lá fora e o que se passa dentro deste mundo interior, que segundo Peirce, nós egoisticamente chamamos de nosso. (1998: p. 30)
\end{abstract}

A concepção que a autora define como dualista diz respeito à ênfase que a percepção coloca no mundo exterior e no agente psicológico, dentro de uma perspectiva cartesiana. Por meio da leitura e contrapondo os diversos autores que estudaram Peirce e sua teoria triádica da percepção, ela explica os diferentes conceitos sobre o termo e a sua visão final dos fatos. Grande parte de sua dedicação é também para esclarecer o básico das relações perceptivas, como a concepção do percepto, que é o que está fora e extrínseco a nós e os julgamentos de percepção - interpretação do percepto.

Alguns autores citados pela autora classificam Peirce como ambíguo nas suas definições de percepto e, por essa razão, os próprios estudiosos trazem novas significações sobre os elementos-chave da teoria da percepção, com variantes de nomenclaturas e interpretações distintas, como no caso percipuum, algo definido por Peirce como o lado mental do objeto. 
Feitas as recorrências aos devidos intérpretes de Peirce, o foco com a semiótica nunca é perdido; então, SANTAELLA volta a inferir sobre a categoria de secundidade, classificando o objeto dinâmico como o percepto e o objeto imediato como o julgamento de percepção.

O que é preciso reter é que o percepto é sempre forasteiro, no sentido de que se força sobre nós, é exterior a nós, sem qualquer passaporte de legalização, preenchendo os requisitos daquilo que Peirce chamava de existente, que não precisa ser necessariamente um objeto físico (...) Ora se o percepto é aquilo que se força sobre nossa atenção, batendo à porta de nossa apreensão, e o percipuum corresponde ao percepto tal como ele é imediatamente interpretado no julgamento de percepção, então, a apreensão do percepto no percipuum, ou melhor, o modo como o percepto, o que está fora, se traduz no percipuum, aquele que está dentro, deve evidente e logicamente, se dar de acordo com três modalidades: primeiridade, secundidade e terceiridade. (SANTAELLA, 1998, p. 57 e 61)

Dadas todas as explicações, a tríade semiótica se aplica nos fundamentos da percepção quando o percepto - cuja origem é aquilo que está fora e se apresenta aos sentidos - está funcionando como objeto dinâmico, algo que está fora do signo.

Portanto, nessa teoria, o indivíduo nunca está separado dos julgamentos que ele produz no ato perceptivo. Essa análise é a primeira noção que elucida a tríade semiótica com a captação do signo. O segundo elemento ou objeto dinâmico é o percepto, aquele que se força sobre a atenção. Portanto, a última comparação que falta é a do interpretante, elemento básico da composição da tríade, e este, na concepção de Peirce, é o percipuum, que corresponde ao percepto tal como ele é imediatamente interpretado no julgamento de percepção.

Santaella (1998) conclui que a percepção é o processo mais privilegiado para colocar na frente do pensamento os três elementos de que o humano é composto: o físico, o sensório e o cognitivo: "se, de um lado, a inserção da percepção no diagrama lógico da semiose ajuda a esclarecer a noção de objeto do signo, de outro, a leitura da percepção à luz da tríade semiótica ajuda a esclarecer a percepção ela mesma" (2004, p. 48).

Do universo perceptivo dos estudos semióticos são extraídos fundamentos para uma interpretação do amplo espectro dos sistemas de signos que as análises tornaram como objetos, como por exemplo, nas análises sobre mídia, publicidade, arte, vídeos, literatura. Como afirma a autora (2005, p.208): “A maioria das estratégias manipuladoras da informação pictórica nos meios de comunicação não são falsificações diretas da realidade expressa de maneira assertiva, mas manipulações através de uma pluralidade de modos indiretos de transmitir significados.” 
3.2 - Semiótica da linguagem do câncer de mama

Aplicando as categorias universais na sua própria concepção de signo, Peirce designou uma rede de classificação de tipos de signos, sendo que o signo sozinho pode estar na primeiridade (qualisigno), na secundidade (sinsigno) ou na terceiridade (legisigno). Dependendo da sua relação com o objeto pode ser um ícone, índice ou símbolo. A relação entre o signo e o interpretante determina os signos do tipo rema, dicente e argumento.

\begin{tabular}{|l|c|c|c|}
\cline { 2 - 4 } \multicolumn{1}{c|}{} & \multicolumn{3}{c|}{ Divisão dos Signos } \\
\hline Categoria & Signo em relação a si mesmo & Signo em relação ao objeto & Signo em relação ao interpretante \\
\hline Primeiridade & quali-signo & Ícone & Rema \\
\hline Secundidade & sin-signo & Índice & Dicissigno \\
\hline Terceiridade & legi-signo & Símbolo & Argumento \\
\hline
\end{tabular}

Tabela 7 - Divisão dos signos na semiótica peirceana - Fonte: Coelho Teixeira (1980, p. 62)

Segundo Perez (2004, p. 155), na primeiridade, os signos ainda estão em possibilidades qualitativas; são observados nas suas propriedades internas, nos aspectos sensórios chamados de quali-signos, tais como, linguagem visual, cores, linhas, formas, texturas, brilho, movimentos. "Trata-se das primeiras impressões que um signo é capaz de despertar sem entrarmos no nível da interpretação. Poderíamos classificar como a impressão que um signo é dotado e é capaz de gerar - exemplo - vermelhidão, grandeza, brilho etc."

$\mathrm{Na}$ secundidade, os signos são mais contundentes, analisados como existentes concretos em seus modos particulares. Algo que existe aqui e agora em um específico contexto. "Quando analisamos as mensagens na sua perspectiva convencional, no seu caráter geral de algo que pertence a uma determinada classe de coisas, estamos analisando os legisignos." Finalmente, na terceiridade, os signos passam do concreto à abstração. O símbolo é uma associação arbitrária; não depende de semelhanças ou vinculações com seu objeto.

O signo câncer de mama, por si só, já é de alto poder simbólico há milênios; porém, devido ao crescimento da doença no século XXI, hoje, seus referenciais e interpretantes atingem maior grau de impacto comportamental.

Como já comentado, no contexto de caracterização das representações simbólicas e figurativas da linguagem contemporânea, as palavras relativas à doença são carregadas de fortes interpretações, como por exemplo, maligno ou benigno, células invasoras, entre outras. 
O caráter lingüístico das doenças, e especificamente do câncer, assume um contexto metafórico e automaticamente pesado conforme as associações estabelecidas entre vida e morte, levando-se em consideração as perdas e ganhos das pacientes com a retirada do seio. Ou seja, como são enfrentadas as questões como a "perda da feminilidade" e as dificuldades das pacientes na relação com os amigos e parentes, seus problemas relacionados ao emprego, entre outros.

$\mathrm{Na}$ visão semiótica, é possível entender que a palavra câncer associada à proliferação de qualquer malefício, não necessariamente a enfermidades, é usada em diferentes contextos da linguagem da comunicação humana. Os objetos de estudo encontram-se nos jornais, em discursos políticos e na mídia em geral. $\mathrm{Na}$ área da publicidade, a tendência é notável, pois apesar de descrever de uma maneira bem mais sutil, prioriza o discurso do "combate" à doença, com ênfase menor na quebra dos estigmas de aceitação da adversidade da contração.

Dessa malha de signos gerada pelas palavras câncer de mama, é possível ligar as partes mais conhecidas do que Peirce estabeleceu ao dividir a rede triádica de todo e qualquer signo, relacionando-as com a hierarquização dos elementos formais. A ligação entre a divisão e a categorização dos signos e a doença ficaria da seguinte maneira:

* Primeiridade - Quali-signo - a qualidade livre do signo: o tumor

* Secundidade - Sin-signo - qualidade de ação e reação dos fatos concretos representações físico-emocionais da doença - contexto

* Terceiridade - Legi-Signo - qualidade de medição, processo de crescimento contínuo do signo - morte ou vida 


\section{3 - Campanha - O câncer de Mama no Alvo da Moda}

O Instituto Brasileiro de Controle do Câncer - IBCC foi fundado ${ }^{42}$ em 1968 e já atendeu mais de três milhões de mulheres. Segundo os dados divulgados pela instituição, seu hospital é referência para a saúde feminina na área de tratamento dos cânceres de mama e ginecológico, os quais representam $60 \%$ do total de sua demanda. A média de atendimentos pelo Sistema Único de Saúde (SUS) é de $85 \%$ dos casos. Cabe ressaltar que o instituto realiza uma média de 13 mil mamografias e 21 mil ultra-sonografias por ano.

A divulgação do IBCC é realizada por uma forte campanha nacional O Câncer de Mama no Alvo da Moda. A estratégia consiste na captação de recursos para venda de edições limitadas de camisetas, cujos modelos apresentam um logotipo azul em forma de circunferências, formando um alvo. O símbolo foi desenhado pelo estilista de roupas norteamericano Ralph Lauren, e todos os anos, é atualizado e modificado.

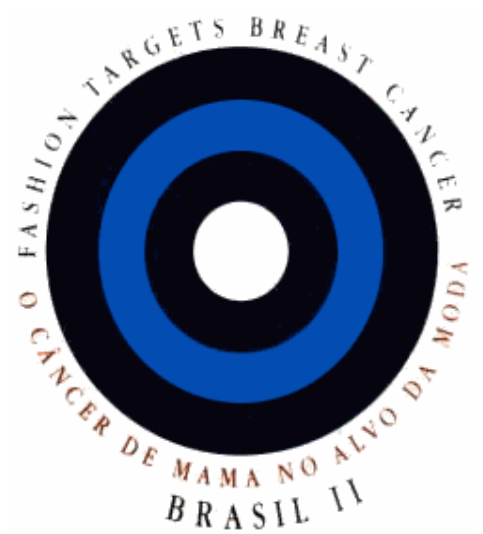

Figura 9. Identidade visual da marca $O$ câncer de mama no alvo da moda

${ }^{42}$ Os fundadores do IBCC, os Profs. Drs. João Sampaio Góes Jr. e João Carlos Sampaio Góes, foram os responsáveis pela instalação do primeiro mamógrafo que funcionou no Brasil - www.ibcc.org.br 
Apesar de ter sido criada nos EUA, foi no Brasil que a campanha tomou proporções significativas, desenvolvendo ações de marketing como a Corrida e Caminhada Contra o Câncer de $\mathrm{Mama}^{43}$. Além desse evento, também há o investimento na venda de produtos licenciados, com 250 artigos comercializados e o prêmio IBCC de jornalismo, cujo intuito é estimular as pautas sobre o tema. Pode-se mencionar o São Paulo Fashion Week como a mais importante das parcerias, quando em desfiles de moda anuais, o símbolo da campanha é redesenhado e levemente modificado para exibir um caráter mais contemporâneo, conquistando assim uma constante atualização no mercado.

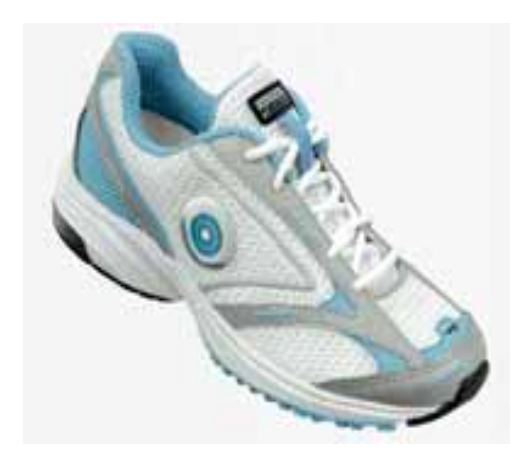

Figura 10 - Exemplo de produto licenciado da marca

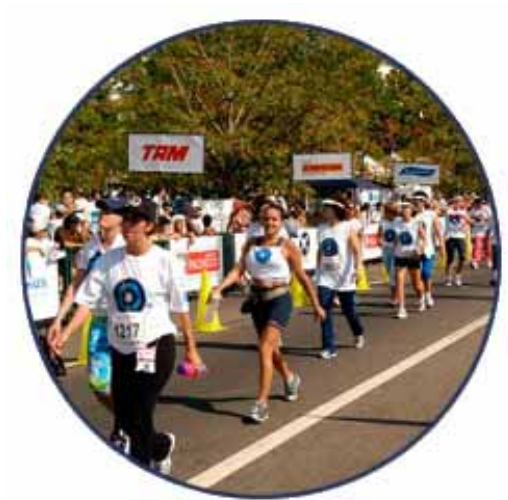

Figura 11 - Corrida e Caminhada Contra o Câncer de Mama

Os números divulgados sobre a arrecadação e crescimento da campanha desde a idealização em 1995 até o momento são cerca de R\$ 40 milhões arrecadados, com mais de 8 milhões de camisetas vendidas em 800 modelos diferentes confeccionados. O total custeou parte dos tratamentos dos pacientes do IBCC e contribuiu com as obras de ampliação do hospital em mais de 5 mil metros quadrados ${ }^{44}$.

A Corrida e Caminhada Contra o Câncer de Mama é uma ação integrante da campanha O Câncer de Mama no Alvo da Moda; configura-se como um evento de arrecadações financeiras em prol do IBCC, reunindo empresas, hospitais e comunidade. Em 2005, a iniciativa atingiu dez cidades do Brasil.

${ }^{44}$ http://www.ibcc.org.br/indexSite.htm 
Segundo o site do instituto, os dados sobre a Corrida e Caminhada também já alcançaram altos patamares e corroboram o sucesso da marca da campanha $O$ Câncer de Mama no Alvo da Moda:

Número de edições realizadas desde 1999 - 36

Número de edições em São Paulo desde 1999 - 9

Valor arrecadado em todas as cidades - Mais de 1 milhão de reais

Valor arrecadado em São Paulo - R\$ 270.000 (computados desde 2003)

Número de participantes em todas as cidades - Mais de 80 mil

Número de participantes em São Paulo - 30.600 (aproximadamente)

Número de instituições beneficiadas até hoje - Mais de 10

Número de atores e atrizes em prol da causa - mais de 220

A utilização de pessoas famosas é a principal característica de persuasão da mensagem desenvolvida nessas propagandas. Uma definição com vistas à identificação da receptora com o produto/causa comunicado, o que, segundo PEREZ (2004, p.134), oferece uma qualidade de fenômeno extensionista e de caráter exibitório da marca. Ou seja, ao se permutarem conceitos de marca e produto, pode-se determinar mais visibilidade para as personagens do que para a luta contra a doença.

A desmaterialização do consumo tornou a noção de produto intangível cada vez mais vaga e profunda. As práticas de consumo são mais e mais impregnadas de instâncias simbólicas e sócio-culturais. De valor ajoutée do produto, o objeto de troca é o sentido. (2004, p.134)

Essa significação advém das novas tendências da cultura contemporânea, carente de ideologias, quando marcas se tornam substitutas de crenças e valores humanos, como comentou Bosi (2000, p.142) em suas pesquisas sobre o uso e a vanglória dos heróis como uma tentativa de omissão dos problemas enfrentados pelo gênero feminino. 
A interpretação freudiana procura abranger sobre o mesmo conceito todas as atividades de "desrealização" de que é capaz o espírito humano: arte, mito, contos folclóricos e acrescentaríamos as infinitas imagens de vítimas e heróis que povoam a imprensa de nossos dias (...) que se ocupa largamente com a vida de artistas, princesas, campeões, playboys, constituindo o "Olimpo" da cultura de massas e que, por isso, são denominadas "personagens olimpianos".

É comum encontrar personalidades do meio artístico trabalhando em prol da causa do combate ao câncer, e uma das hipóteses para essa adoção é a cobertura excessiva da imprensa sobre a vida de pessoas famosas. Kushner acredita que o tema mastectomia ultrapassou o anonimato quando pessoas conhecidas sofreram a cirurgia; todavia, o tema continuou sendo superficialmente comentado.

E não falta publicidade sobre a detecção precoce do primeiro câncer. Quando as então primeira e segunda damas do país - as esposas do ex-presidente Gerald Ford, e a do ex-vice-presidente Nelson Rockefeller - sofreram mastectomias, era difícil encontrar um jornal, uma revista, um programa de rádio ou de televisão que não fornecessem instruções para o auto-exame e que não falassem dos sete sinais de perigo para o câncer. Isto foi realmente uma contribuição magnífica para a instrução geral das mulheres. Mas, para as mulheres como eu, que já tiveram câncer, com alto risco de reincidência, em nenhum lugar encontrei um artigo ou uma entrevista sobre como detectar os sinais precoces de reincidência ou de uma metástase. (KUSHNER,1981, p. 104)

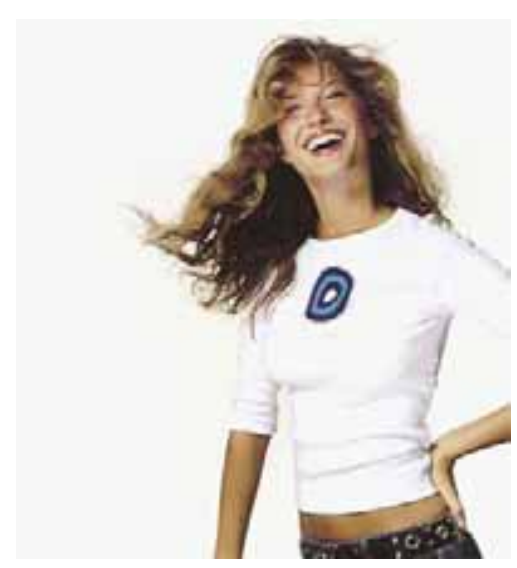

Figura 12 - Foto de revista com a modelo Gisele Bündchen 


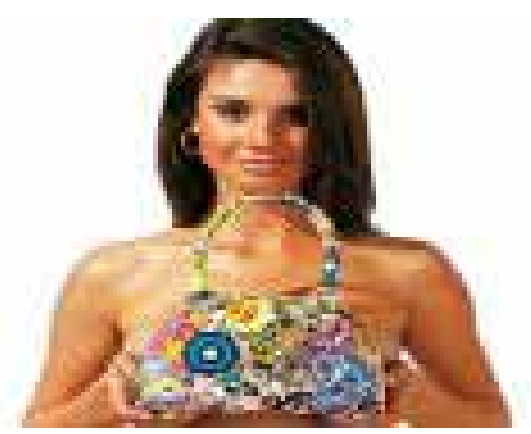

Figura 13 - Exemplo de propaganda no site do IBCC

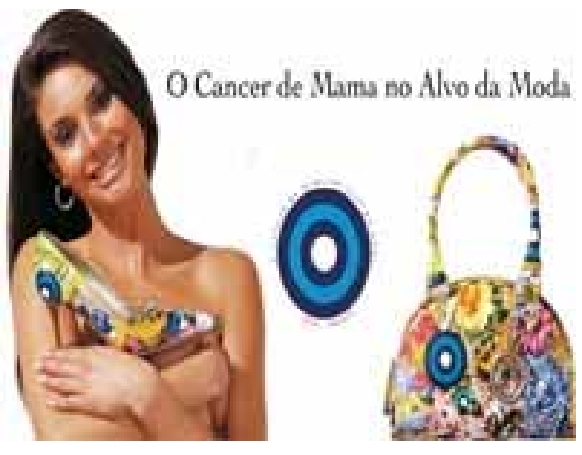

Figura 14 - Exemplo de propaganda em outdoor da campanha do IBCC

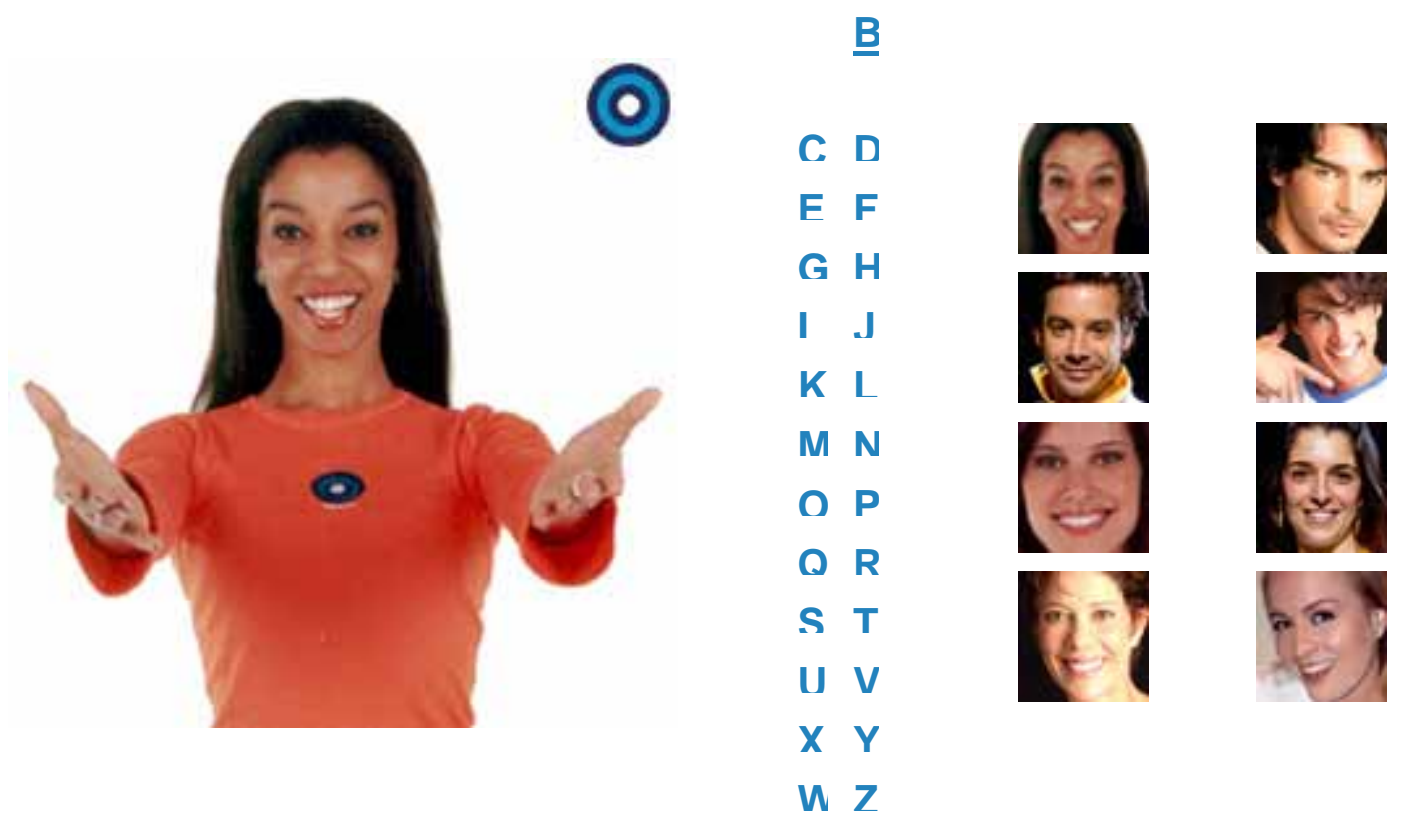

Fígura 15 - A atriz Adriana Lessa na página do site, na qual constam todos os atores e personalidades famosas participantes da campanha 

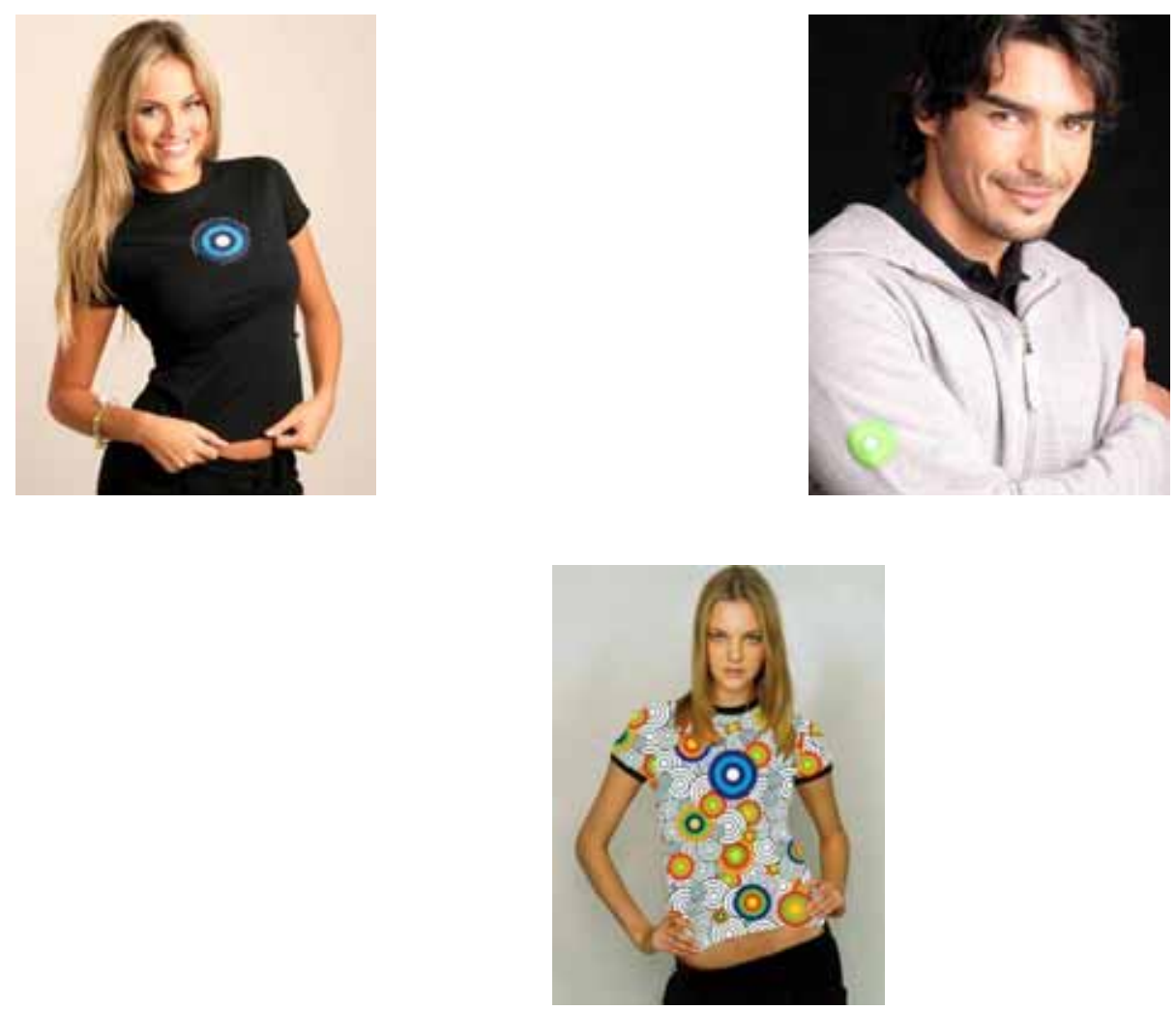

Figuras 16, 17 e 18 - Modelos da campanha e as diferentes adaptações do símbolo da marca da campanha

Se por um lado existe a crítica na incorporação das celebridades, ou seja, dos portavozes da audiência-alvo, e na simbologia dos valores de transferência, por outro, existem também os benefícios que essa utilização gera ao preço final do produto anunciado e à marca como um todo. Conforme mostra a Figura a seguir, adaptada de AAKER (1996), pode-se entender a proposta de valor da marca da campanha como a soma dos dados positivos de expressão e utilização humana.

Utilizando-se do exemplo da camiseta da campanha, o benefício primeiro seria a necessidade de vestimenta. Logo após, os elementos secundários, como adesão à causa e a característica de personalidade politicamente correta, estariam todos também agregados ao valor final do produto. 
Benefícios funcionais

Utilização/vestimenta

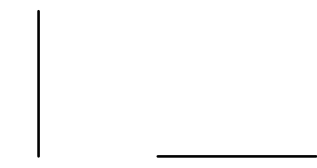

Benefícios Emocionais Adesão à causa
Benefícios de Auto-Expressão

Politicamente correta
Preço

Relativo

Figura 19 -Quadro sobre a proposta de valor da campanha O Câncer de Mama no Alvo da Moda

Fonte: Aaker. (Criando e Administrando Marcas de Sucesso, 1996, p.116)

Faz-se necessário mencionar que o público-alvo da campanha é composto por jovens, e os produtos desenvolvidos são normalmente vinculados a empresas de adesão de altos níveis socioeconômicos. As camisetas em modelo regata, baby look e os pequenos tamanhos oferecidos para o consumidor são comumente enquadrados ao vestuário jovem. Entretanto, diferentemente dos consumidores da marca, o público portador da doença está entre 40 e 70 anos de idade.

$\mathrm{Na}$ análise da campanha, a linha semiótica Peirceana foi adotada por oferecer subsídios para contemplação, observação e sistematização dos signos. Aplicada à publicidade, essa teoria auxilia na conscientização do referencial proposto pelo material de divulgação e pelos potenciais retornos sobre os entendimentos do público receptor. Sendo assim, é possível decifrar os códigos da comunicação como um todo e desenvolver ações de propaganda com um embasamento responsável e crítico no que se refere à autoria das mensagens e aos efeitos que se pretende causar.

Os critérios para aplicação do método semiótico envolvem a capacidade do indivíduo de contemplação, distinção e generalização do signo estudado. Estas são as atividades iniciais de desenvoltura para um olhar capacitado dos referenciais estudados. Quando assumida a prática dessas três capacidades, é possível entender de maneira mais abrangente o signo e, conseqüentemente, todos os elementos publicitários e suas competências potenciais para produzir/gerar interpretantes.

No caso da campanha O Câncer de Mama no Alvo da Moda do IBCC, pretende-se discutir as ações de publicidade desenvolvidas, visando analisar os elementos sígnicos da identidade marcária, como suas cores, textos e todas as nuances publicitárias, bem como 
ponderar sobre os efeitos dessa linguagem comunicativa no processo de recepção e nas atitudes da mulher receptora.

\subsubsection{Slogan}

O slogan como parte da linguagem publicitária intervém diretamente em toda a realidade do produto e da marca, produzindo símbolos de expressão do anunciante e da cultura dos valores desejados. Dos elementos da identidade marcária é o mais facilmente modificado devido à sua sinteticidade usual, o que o torna constantemente reciclável, e ao fato de induzir as marcas ao conceito de contemporaneidade. Seu processo criativo resulta sempre de transgressões da linguagem comum da propaganda, seja ela escrita, sonora ou visual, e sua originalidade se deve ao reconhecimento do contexto semiótico no qual cada slogan coleta signos e produz novas semioses.

Segundo IASBECK (2002, p.123), "as técnicas de construção do sintagma verbal geram significações, os parentescos e afinidades com fórmulas históricas, o material lingüístico de que os slogans se apropriam para promover impacto, comunicação imediata e despertar o interesse. Elementos decifradores e geradores de significados das relações de cultura, reproduzidos em formas de frases proverbiais, máximas, lemas, ditos populares e trazidos ao campo de atuação da publicidade na condensação de poucas palavras com o intuito da comunicação imediata".

Um dos recursos que o autor utiliza para explicar a criação dos slogans é a estrutura poética através do aspecto fonético, quando a composição das palavras causa um paralelismo métrico na equalização da emissão dos sons. No caso da campanha do IBCC, temos: O câncer de mama no alvo da moda. As palavras mama e moda realçam e equilibram a sonoridade da oração, facilitando a assimilação e a aprendizagem da mensagem.

Outro fator é o conceito de contemporaneidade com as palavras alvo e moda, sugestivas de focos de interesses, cujos significados transmitem características de conduta social e atual por meio da utilização das roupas. Mas, ao pensar que o que está no alvo da moda é uma doença, a inversão pode se tornar omissa ou pejorativa, pois oculta o caráter da seriedade da situação. Em primeira instância, causa estranheza ao interpretar que uma doença possa estar no topo da atualidade, e não a sua prevenção. 


\subsection{2 - Semiótica da Cor}

A cor predominante do símbolo da campanha é azul, representante das associações afetivas de confiança e precaução. Uma escolha condizente com as expectativas previstas do público-alvo.

O azul também é a cor preferida no ocidente, com mais apreciação e menos rejeição nas escalas de preferência (vide Figura abaixo), segundo Heller (2005). Em outros estudos de fatores de influência das cores, como o de Farina, Perez e Bastos (2006, p.89), o azul está claramente presente entre as idades de 40 a 50 anos.

Ao analisarmos cientificamente as preferências, verificamos que o cristalino do olho vai se tornando amarelo com o decorrer dos anos. Uma criança absorve $10 \%$ da luz azul, enquanto que um ancião absorve cerca de $57 \%$ (...) Notaremos que o Azul vai na escala de preferência subindo proporcionalmente à idade do indivíduo.

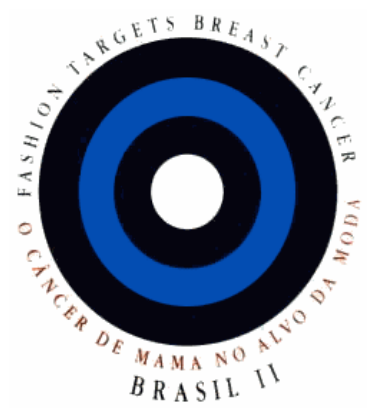

No símbolo da campanha, há também a cor branca e a preta: uma simbolizando vida e luz, e outra, dor, temor, seriedade, austeridade e morte frente à doença.

\begin{tabular}{|l|r|}
\hline Azul & $45 \%$ \\
\hline Verde & $15 \%$ \\
\hline Rojo & $12 \%$ \\
\hline Negro & $10 \%$ \\
\hline Amarillo & $6 \%$ \\
\hline Violeta & $3 \%$ \\
\hline Naranja & $3 \%$ \\
\hline Blanco & $2 \%$ \\
\hline Rosa & $2 \%$ \\
\hline Marrón & $1 \%$ \\
\hline Oro & $1 \%$ \\
\hline
\end{tabular}

\begin{tabular}{|l|r|}
\hline Marrón & $20 \%$ \\
\hline Rosa & $17 \%$ \\
\hline Gris & $14 \%$ \\
\hline Violeta & $10 \%$ \\
\hline Naranja & $8 \%$ \\
\hline Amarillo & $7 \%$ \\
\hline Negro & $7 \%$ \\
\hline Verde & $7 \%$ \\
\hline Rojo & $4 \%$ \\
\hline Oro & $3 \%$ \\
\hline Plata & $2 \%$ \\
\hline Blanco & $1 \%$ \\
\hline Azul & $1 \%$ \\
\hline
\end{tabular}

Figura 20 - Quadro das cores mais e menos apreciadas - Fonte: HELLER (2004, p.5) 


\subsection{3 - Forma e design}

A forma do símbolo da campanha, como já mencionado anteriormente, representa um alvo, objeto cujo atributo fundamental é a precisão para se obter êxito com a sua utilização. É necessário um olhar "clínico" e mira perfeita para se atingir o centro do alvo. Uma mesma comparação pode ser feita com o câncer de mama quando realizada a cirurgia de extração do tumor maligno, a mastectomia.

Outra referência é a citação do dicionário ilustrado de símbolos de BIDERMANN (1993, p.97), no qual a menção à forma circular descreve as ondas anulares do nascimento e da existência humana. "Círculos concêntricos também surgem quando atiramos um objeto na água, os grafismos desse tipo, freqüentes sobre as tumbas monolíticas pré-históricas, podem ser interpretados como símbolos do aprofundar-se nas águas da morte, talvez também do maravilhoso renascimento, no sentido de uma doutrina da morte e da vida". Pensando no objeto de estudo analisado, pode-se considerar uma referência à disseminação e aos ecos da campanha.

Dentro dos diversos signos pertencentes ao formato de alvo da campanha, podem-se considerar as identificações de objetos encurvados com o universo feminino, conforme explica PEREZ (2004, p.59): “a semiótica das formas traz algumas considerações importantes para a construção da expressividade e da sensorialidade marcária por meio da análise das formas e do design (...). Curvas e ondulações expressam dinamicidade, sensualidade e feminilidade".

Por fim, existe a semelhança do desenho com um seio e suas camadas de tecidos e músculos que podem ser representadas pelos círculos do objeto, sendo o branco central do alvo o bico do peito, o leite materno da vida, a luz e a possível erradicação da doença.
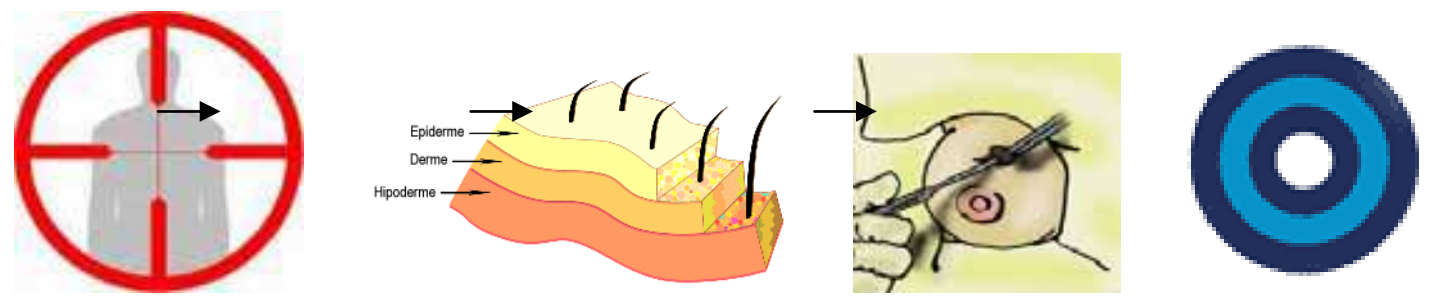

Figura 21 - Possíveis associações do processo criativo do símbolo da campanha "O câncer de mama no alvo da moda" 


\subsection{4 - Tríade semiótica da marca}

A análise por meio da capacidade contemplativa de um determinado produto ou marca no intuito de chegar às suas cadeias de representações é o primeiro passo no desmembrar de uma cadeia sígnica. Feito esse exercício, surgem as noções de segmentação e significação e as diferenças que convergem para o estado de observação e generalização dos signos.

A partir do estudo dos signos surgem as três divisões básicas da semiótica nas quais as características mercadológicas ficam evidenciadas com mais clareza, decifrando os objetivos finais da marca. Percebe-se que no exemplo da campanha, a identidade marcária tem a possibilidade de interferir na rotina real e psicológica dos consumidores, gerando interpretantes de sentimentos e sociabilização e, em último caso, e se devidamente eficaz, também pode gerar a criação de hábitos (interpretante lógico), como por exemplo, o autoexame.

Ao projetar uma aproximação à área de gestão da marca, Perez (2004) entende que o signo é o identity mix, os elementos de expressividade e visibilidade da marca, mencionados nos itens anteriores, o símbolo, o logotipo (texto) e o slogan. Os interpretantes são os efeitos que a marca é capaz de gerar a partir de seu fundamento, como atualidade e valores sociais. Já o objeto diz respeito a tudo que faça referência ao processo mercadológico do produto, ou seja, o marketing mix.

Objeto - Marketing Mix

Produto (Camiseta)

Preço

Comunicação

Pontos e empresas de distribuição

Posicionamento da Marca, etc

\section{Signo - Identity Mix}

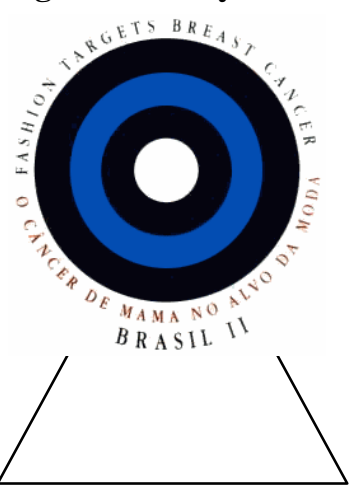

Interpretante Funcional Elegância / Adaptação à Moda

Interpretante Emocional

Status elevado, aceitação social, personalidade politicamente correta e socialmente compromissada

Interpretante Lógico

A campanha possivelmente não atinge, ou seja, não consegue formar hábito, como por exemplo: o autoexame

Figura 22 - tríade semiótica da marca da campanha O câncer de mama no alvo da moda 


\subsection{5 - Considerações sobre a Campanha}

Conceitos-chave e técnicas de propaganda são revividos na criação de campanhas de comunicação, e dessa maneira, diferentes etapas decorrentes do processo de emissão das mensagens e recepção dos destinatários podem ser explicadas por meio de fatores semióticos.

A campanha O Câncer de Mama no Alvo da Moda é um exemplo do poder de persuasão que uma marca exerce na sociedade, em que a ênfase nos artistas é sutilmente mais trabalhada do que a doença em si. Por mais méritos que as imagens deles possam trazer em conversões monetárias ao IBCC, e conseqüentemente às mulheres atendidas pelos hospitais, cabe ressaltar características desse processo de criação publicitária, ausente de precauções e explicações sobre diagnósticos, prevenções, tratamentos, entre outras.

Pode-se presumir que as peças analisadas da campanha não incitam ao auto-exame ou a cuidados para detecção precoce. Relacionar câncer e moda implica ponderar se o públicoalvo final, colaborador e consumidor da campanha, obteve o mínimo de educação sobre o assunto ou apenas aderiu à tendência do mercado das marcas de vestuário.

Atualmente, a expansão das marcas representa grande parte da linguagem nos relacionamentos humanos; por meio de produtos novos constantemente desejados pelo consumidor novos códigos de compra são constantemente criados. Como complementa SEMPRINI (2006, p. 33): “Alguns temem que, uma vez aberto o recinto do consumo, as marcas liberadas nos ambientes da discursividade social acabem por devorar tudo o que estiver no caminho, estremecendo completamente o equilíbrio de todo ecossistema sociosemiótico."

Hoje em dia, a marca representa mais do que o produto, e há no mercado um determinado processo de registro para diferenciá-la. A marca registrada não é nada mais do que uma empresa ou uma instituição que recebeu a proteção legal de sua autoria com vistas à utilização de toda sua identidade, o que pode incluir logotipo, slogan, embalagens, fonte tipográfica, entre outros. No Brasil, o órgão do governo responsável pelo registro da marca é o Instituto Nacional da Propriedade Industrial. ${ }^{45}$

45 O Instituto Nacional da Propriedade Industrial - INPI é uma autarquia federal vinculada ao Ministério do Desenvolvimento, Indústria e Comércio Exterior, responsável por registros de marcas, concessão de patentes, averbação de contratos de transferência de tecnologia e de franquia empresarial, e por registros de programas de computador, desenho industrial e indicações geográficas, de acordo com a Lei da Propriedade Industrial (Lei n. ${ }^{\circ}$ 9.279/96). Fonte: www.inpi.gov.br 
Por outro lado, a definição de marca se constitui no princípio da enunciação, ou seja, tal processo é o que lhe possibilita atravessar de uma condição abstrata e virtual para o estado concreto de manifestação. Em outras palavras, embora não esteja explícito o que é controlar o diagnóstico de câncer de mama, a atitude de compra de um produto licenciado do IBCC, com a logotipia da campanha pode trazer benefícios sociais, definidores e até ideológicos.

A especificidade marcária na análise comunicativa revela sua instância semiótica de segmentação e atribuição de sentido aos códigos humanos, sejam estes de forma ordenada, estruturada ou voluntária. "O poder semiótico da marca consiste em saber selecionar os elementos no interior do fluxo de significados que atravessa o espaço social, organizá-los em uma narração pertinente e atraente e a propô-los a seu público" (SEMPRINI, 2006, p.107).

A conversão de um número crescente de setores da produção de bens e de serviços em marcas amplia-se com o fenômeno do consumo de massa, transgredindo a lógica do custo/benefício de bens tangíveis e concretos para simbologias circunscritas às características humanas. PEREZ comenta o início desse fenômeno, quando grande parte dos produtos básicos, como os alimentícios, móveis e louças, eram feitos nas casas, por artesãos, ou comprados nos armazéns a granel.

\begin{abstract}
Nesse contexto de consumo, as marcas assumem destaque nas relações de compra e venda, indo além da idéia de meras facilitadoras das transações comerciais para transformar-se em poderosos e complexos signos de posicionamento social e de ser no mundo. (...) Nunca tivemos um número tão grande de propagandas igualmente conseqüentes em comunicação. A gerência de marcas ofereceu alguma esperança de ordem em meio à confusão decorrente da prosperidade pós-guerra, que salientava a necessidade da criação de uma identidade para as empresas. (Perez, 2004: p. 3 e 5)
\end{abstract}

Por intermédio de seu poder de mercado e influência no comportamento humano, a marca comercial tornou-se um "veículo de adesão social” " ${ }^{46}$, o que, por conseguinte, embute um novo caráter de exibição e ostentação sobre sua utilização. Sua autoridade no espaço público tem capacidade para apontar o simbólico e o imaginário de indivíduos e grupos e atrair a atenção dos veículos de comunicação. Atualmente, a marca é mais do que um objeto

\footnotetext{
${ }^{46}$ Perez define tal fenômeno como uma realidade à disposição dos indivíduos nas sociedades excessivamente desideologizadas e sedentas por entidades que permitam coesão.
} 
de consumo; é um traço definidor de alcance em todo o entorno social, com signos semióticos permeados de significação, de formalização e de valorização de sentido, atuando livremente nos mecanismos de construção da identidade social.

Talvez a ascensão da campanha O Câncer de Mama no Alvo da Moda se deva à necessidade de a população brasileira atuar na luta contra o câncer de mama, mas o fator do sucesso de vendas das camisetas e do reconhecimento da marca entre o público nacional consiste na utilização das personagens famosas. Os signos expostos nessas peças publicitárias são considerados extremamente eficazes na medida em que o lucro econômico do IBCC aumenta cada vez mais e se ampliam os serviços prestados pelo seu hospital. Porém, quanto ao viés da área de comunicação, pode-se considerar que ainda existe uma ausência de informações relativas à doença nas análises mencionadas, e talvez as mensagens publicitárias criadas ofereçam mais destaque ao artista do que à causa da doença em si. 


\section{Capítulo IV}

Comunicação pública de saúde e o INCA 


\section{1 - Iniciativas governamentais sobre cânceres femininos}

Durante a realização da pesquisa foram feitas diversas solicitações de materiais de comunicação do Ministério da Saúde sobre câncer de mama. A escolha da análise das ações tanto do IBCC quanto do Inca se deve à disparidade comunicativa e alcance midiático de ambas as iniciativas no panorama das práticas de saúde feminina no Brasil.

O Inca é o órgão do Ministério da Saúde do Brasil, vinculado à Secretaria de Atenção à Saúde, responsável por desenvolver e coordenar ações integradas para a prevenção e controle do câncer no país. O Instituto completou recentemente 70 anos de existência, com cinco unidades desenvolvendo trabalhos nas áreas de prevenção, controle, pesquisa e ensino, e se tornou a única instituição da América Latina convidada pela OMS - Organização Mundial de Saúde a integrar seu Comitê Consultivo de Controle de Câncer.

Por meio da análise das peças de publicidade do governo realizadas pelo Inca pretende-se averiguar qual é a comunicação estabelecida pelo governo para o câncer de mama no Brasil a partir da década de 80. Diferentemente das ações em destaque no último subcapítulo sobre a campanha O Câncer de Mama no Alvo da Moda do IBCC, as ações do Inca não são contínuas, não chegam a constituir uma campanha, mas consistem em atuações pontuais de promoção de saúde.

A história do governo sobre o combate aos cânceres femininos se iniciou na década de 90. Contudo, as primeiras ações de divulgação nacional foram voltadas única e exclusivamente ao câncer de colo de útero. Nota-se que a difusão publicitária em larga escala sobre o câncer de mama ocorreu um pouco mais tarde, entre 1999 e 2001; entretanto, não aconteceu em forma de campanha comunicacional, tampouco atingiu os diferentes Estados do país.

Todavia, atualmente, o câncer de colo de útero possui taxas de incidência menores que o de mama, exceto na região Norte do país. Por razões como falta de condições básicas de higiene e pelo alto número de casos de HPV, vírus do papiloma humano, uma doença sexualmente transmissível, que atinge em média entre $25 \%$ e $50 \%$ da população feminina mundial, a doença ainda possui alta incidência e mortalidade nesses Estados brasileiros.

A análise do câncer de colo de útero faz-se significativamente válida neste estudo, cuja totalidade de materiais é escassa, e espera-se traçar, a partir da compreensão dessas primeiras ações, um possível panorama do início da publicidade pública de saúde voltada para a mulher.

Segundo dados fornecidos pela Coordenação de Prevenção Vigilância do INCA COMPREV, em 1984 aconteceram as primeiras ações para controle do câncer de colo e 
mama no Brasil no contexto do Programa de Assistência à Saúde da Mulher. Em 1989, ocorreu a difusão dos primeiros Manuais para Controle do Câncer de Mama na rede assistencial à doença.

Em 1991, foi lançada a campanha Um Toque de Vida e, em 1994, foi editado o Manual e Normas técnicas para o Controle do Câncer Cérvico-uterino e de Mama, além do Manual de Bolso com Orientações Técnicas sobre câncer de colo e Mama. Em 1995, apareceu a Atualização das Recomendações para Deteç̧ão do Câncer de Mama. Em 1996, o livreto Falando sobre Doenças da Mama. Em 1997, ocorreu a continuação da campanha Um Toque de Vida (vide anexo Inca - I). Em 1998, Sem Tempo a Perder - manual para agentes de saúde, Oficina de Trabalho para Preparação de um Programa de Detecção Precoce do Câncer de Mama e a Oficina de Trabalho - Câncer de Mama - Perspectiva de Controle (Os materiais publicitários disponíveis serão analisados nos próximos itens e os manuais e as peças de teor técnico estarão disponíveis nos anexos da dissertação).

Das ações e atividades listadas acima, excetuando apenas a campanha Um toque pela Vida cujo material não foi fornecido, presume-se que foram iniciativas voltadas para os profissionais de saúde e pouco atingiram a mulher que ainda não precisara procurar um posto médico e/ou hospital. A preocupação dessa primeira etapa foi apenas a de treinar e capacitar os agentes diretamente envolvidos com a questão do câncer de mama.

Aconteceu também na década de 90 a consolidação do Inca na liderança das ações de câncer no Brasil em todas as suas vertentes, pois durante algumas épocas e em trocas de governo, os serviços prestados pelo instituto mudavam de coordenação, quando o Ministério da Saúde assumia o controle das ações de comunicação.

No ano de 1995, realizou-se a VI Conferência Mundial sobre a mulher na China, e o governo brasileiro se comprometeu na dedicação dos problemas de saúde feminina, quando até então nada havia feito nesse aspecto. O Brasil assumiu o compromisso de desenvolver um programa de âmbito nacional visando o controle do câncer de colo de útero, e ocorreu em 1997 a implantação do Projeto-piloto Viva Mulher - Programa Nacional de Controle do Câncer de colo de útero em seis localidades: Curitiba, Brasília, Recife, Rio de Janeiro, Belém e no Estado de Sergipe.

O Programa Viva Mulher nasceu prioritariamente como uma campanha exclusiva para o controle do câncer de colo de útero no Brasil. A primeira fase, chamada de Projeto-piloto, ocorreu de 1997 até o final do primeiro semestre de 1998, quando foram realizadas pesquisas 
com mulheres e profissionais de saúde, considerando cinco Municípios e um Estado brasileiro. O objetivo final era estimular o público-alvo feminino de 35 a 49 anos de idade a fazer o seu primeiro exame citopatológico, o popularizado "papanicolau".

Já nos anos de 1999 a 2001, depois de dois anos de projeto-piloto, houve a expansão do Programa Viva Mulher em âmbito nacional. Nessa nova fase, ocorreu a implantação do SISCOLO (Sistema de Informações de Controle do Câncer do Colo do Útero) e a inserção do Programa de Controle de Câncer de Mama no Programa Viva Mulher por meio da capacitação dos Estados e da distribuição de equipamentos às Secretarias Estaduais de Saúde.

As ações voltadas para a detecção precoce do câncer de mama foram reforçadas a partir de 2000, com a habilitação dos profissionais de saúde, estabelecendo a cooperação técnica e científica entre os participantes para o desenvolvimento das atividades referentes ao Programa Viva Mulher, com o uso de 50 mamógrafos que foram distribuídos nacionalmente segundo critérios próprios das Secretarias Estaduais de Saúde.

Em novembro de 2003, o Ministério da Saúde, a partir de um trabalho conjunto entre o Inca, a Área Técnica da Saúde da Mulher - Secretaria de Atenção à Saúde - SAS e a Sociedade Brasileira de Mastologia, publicou o Controle do Câncer de Mama - Documento de Consenso. Esse material adverte para os procedimentos particulares voltados ao controle do câncer de mama nas áreas referentes à prevenção, detecção precoce, diagnóstico, tratamento e cuidados paliativos.

Segundo o Inca, em 2004, as ações do Programa Viva Mulher foram integradas às desenvolvidas pelo Projeto Expande e pelo Projeto de Qualidade em Radioterapia. No ano de 2005, foi lançado o Plano de Ação para o Controle dos Cânceres do Colo do Útero e da Mama. Diretrizes Estratégicas 2005-2007. As estratégias têm como objetivos reduzir a ocorrência (incidência e mortalidade) e as repercussões físicas, psíquicas e sociais causadas por esses tipos de câncer por meio de ações de prevenção, oferta de serviços para detecção em estágios iniciais da doença e para tratamento e reabilitação das mulheres. Para alcançar esses objetivos foi elaborado um Plano de Ação com definição de seis diretrizes estratégicas:

- Aumento da Cobertura da População-Alvo;

- Garantia da Qualidade;

- Fortalecimento do Sistema de Informação;

- Desenvolvimento de Capacitações; 
- Desenvolvimento de Pesquisas;

- Mobilização Social composta por ações a serem desenvolvidas a partir do ano de 2005 nos distintos níveis de atenção à saúde.

No mesmo ano de 2005, foi publicada a Portaria GM/MS n 2.439 de 08/12/2005, que instituiu a Política Nacional de Atenção Oncológica (Promoção, Prevenção, Diagnóstico, Tratamento, Reabilitação e Cuidados Paliativos) a ser implantada em todas as unidades federais. Essa Portaria prevê que o Plano de Controle dos Cânceres do Colo do Útero e da Mama deve ser parte integrante dos Planos Municipais e Estaduais de Saúde.

A recente publicação da Portaria no 399/GM de 22/02/2006 - Pacto pela Saúde, 2006, trouxe uma agenda de compromissos para a área, estabelecendo entre o Ministério e as Secretarias Estaduais e Municipais o fortalecimento do Sistema Único de Saúde. Este constitui a definição de prioridades articuladas e integradas por meio de três convenções: Pacto pela Vida, Pacto em Defesa do SUS e Pacto de Gestão. Cabe a esta pesquisa explicar o Pacto pela Vida, que visa proporcionar reforços por resultados nítidos, com metas regionais e nacionais, e entre suas prioridades, define a redução da mortalidade por câncer de colo de útero e de mama.

Hoje, o Pacto pela Vida está em consonância com as diretrizes estratégicas do Plano de Ação para o Controle dos Cânceres do Colo do Útero e de Mama - 2005-2007, e a união deles é um dos componentes fundamentais da Política Nacional de Atenção Oncológica.

Percebe-se com essa trajetória que muitas são as denominações e acordos feitos para as iniciativas públicas do câncer de mama, sendo que as ações nem sempre foram introduzidas nos programas executados à época. A prioridade do estudo de comunicação cabe ao Programa Viva Mulher, cuja extensão em meados de 1999 incorporou a preocupação com o câncer de mama e desenvolveu uma única campanha nacional. Hoje, por meio da análise do histórico estabelecido, pode-se dizer que a prática das ações regionalizadas fez com que o conceito de uma grande campanha fosse trocado por constantes ações de promoção da saúde pública feminina.

Há de se observar que, mesmo tardiamente divulgadas e acopladas a um programa nacional de atenção à saúde, as iniciativas de comunicação para o controle do câncer de mama podem oferecer grandes conquistas para a mulher brasileira. Serão analisadas as evoluções da identidade desses materiais produzidos na fase anterior ao Programa Viva Mulher no desenvolvimento do referido programa e nas últimas publicações divulgadas com a 
incorporação das diretrizes do Pacto pela Viva. É de relevância para esta pesquisa analisar a proximidade que esses materiais puderam estabelecer com seu público-alvo, considerando características da área de publicidade e da linguagem constituída, cuja evolução demonstra as tendências da comunicação.

Quadro cronológico das ações do INCA

- 1984 - Primeiras ações para controle do câncer de colo e mama no Brasil no contexto do Programa de Assistência à Saúde da Mulher.

- 1989 - Difusão dos primeiros Manuais para Controle do Câncer de Mama na rede assistencial à doença.

- 1991 - Campanha Um Toque de Vida com a imagem da atriz Cássia Kiss.

- 1994 - Manual e Normas técnicas para o Controle do Câncer Cérvico-uterino e de Mama e Manual de Bolso com Orientações Técnicas sobre câncer de colo e Mama.

- 1995 - Atualização das Recomendações para Detecção do Câncer de Mama.

- 1996 - Livreto Falando sobre Doenças da Mama.

- 1997 - Continuação da campanha Um Toque de Vida e implantação do Projeto Piloto Viva Mulher - Programa Nacional de Controle do Câncer do Colo do Útero em seis localidades: nas cidades de Curitiba, Brasília, Recife, Rio de Janeiro, Belém e no Estado de Sergipe.

- 1998 - Sem Tempo a Perder - manual para agentes de saúde, Oficina de Trabalho para Preparação de um Programa de Detecção Precoce do Câncer de Mama e a Oficina de Trabalho - Câncer de Mama - Perspectiva de Controle.

- 1999 a 2001 - Expansão do Programa Viva Mulher em âmbito nacional, implantação do SISCOLO (Sistema de Informações de Controle do Câncer do Colo do Útero) e a inserção do Programa de Controle de Câncer de Mama no Programa Viva Mulher.

- 2003 - Controle do Câncer de Mama - Documento de Consenso.

- 2005-2007 - Plano de Ação para o Controle dos Cânceres do Colo do Útero e da Mama. Diretrizes Estratégicas. 


\title{
4.1.1. Primeiros folhetos de comunicação do Inca
}

Antes da criação e da publicação de algumas peças publicitárias, as agências e os clientes responsáveis pelo produto/serviço realizam pesquisas focais com o intuito de estabelecer uma ligação mais direta e concreta com o seu público-alvo. O grupo focal é uma técnica de avaliação que oferece informações qualitativas, normalmente promovendo uma discussão que tem por objetivo revelar percepções, experiências e preferências.

No caso dos primeiros folhetos divulgados sobre saúde feminina, o Inca adotou o grupo focal como técnica para a identificação na concepção de sua propaganda, e desta coleta de dados, percebeu-se que a escolha por desenhos de caricaturas jovens, ao invés de fotos de mulheres reais, foi uma opção das participantes da atividade de pesquisa publicitária. ${ }^{47}$

\begin{abstract}
Para a produção do material educativo, inicialmente realizaram-se pesquisas qualitativas, em especial grupos focais, onde a opinião das mulheres e dos profissionais de saúde foi ouvida e onde foram avaliadas as características dos materiais a serem elaborados e testada a programação visual, linguagem e a mensagem proposta, garantindo-se seu entendimento, adequação e utilização. Esta atividade contou com a participação de um grupo feminista pernambucano (SOS Corpo), enquanto o desenvolvimento de material de comunicação contou com a participação de setores universitários do Rio de Janeiro (Universidade Estadual do Rio de Janeiro). (INCA, 2000, p.28)
\end{abstract}

A utilização dos bonecos pode representar uma iniciativa didática e informal de abordagem sobre temas complicados como o câncer de mama. $\mathrm{O}$ desenho remete à alegria infantil dos quadrinhos, uma maneira fácil de transmitir mensagens, um elemento de caracterização com formas que lembram a realidade e o corpo humano. Muitas vezes, o desenho pode se tornar uma mascote publicitária e estar presente em toda uma linha de comunicação de determinada marca.

O primeiro folheto explica por meio de quadrinhos os primeiros passos de uma mulher para a prevenção do câncer de colo de útero. A linguagem é simples, interage com a rotina de uma mulher e a presença de um ginecologista. O texto esclarece sobre a rapidez, a ausência de dor e o caráter gratuito do exame. O título na frente da página é bem visível e chamativo: “O câncer de colo de útero pode ser evitado”, e no verso, divulga-se a conclusão: “... e só depende de você. Basta fazer o exame preventivo periodicamente." O papel possui formato

\footnotetext{
${ }^{47}$ Informações retiradas em entrevistas realizadas com a equipe de comunicação e do CONPREV - Coordenação de Prevenção Vigilância do INCA durante os meses de julho a novembro de 2007 e dos relatórios recebidos sobre o Programa Viva Mulher dos anos de 2000 e 2002.
} 
simples, dobrável, o que otimiza a utilização dos dois lados do folheto. O símbolo do Inca possui linhas retas e se assemelha a um gráfico.
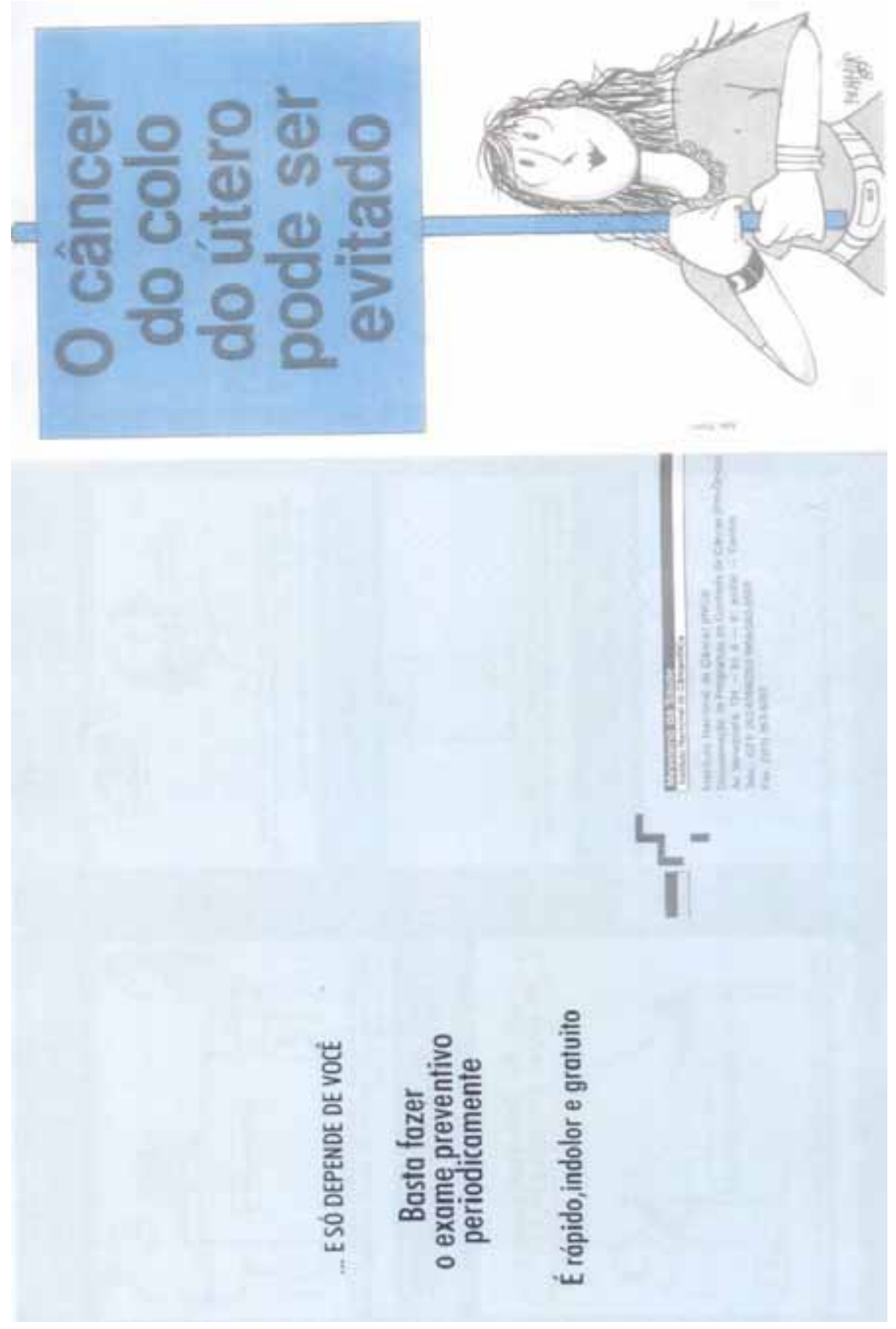

Figura 23 - Folheto 1 - frente 

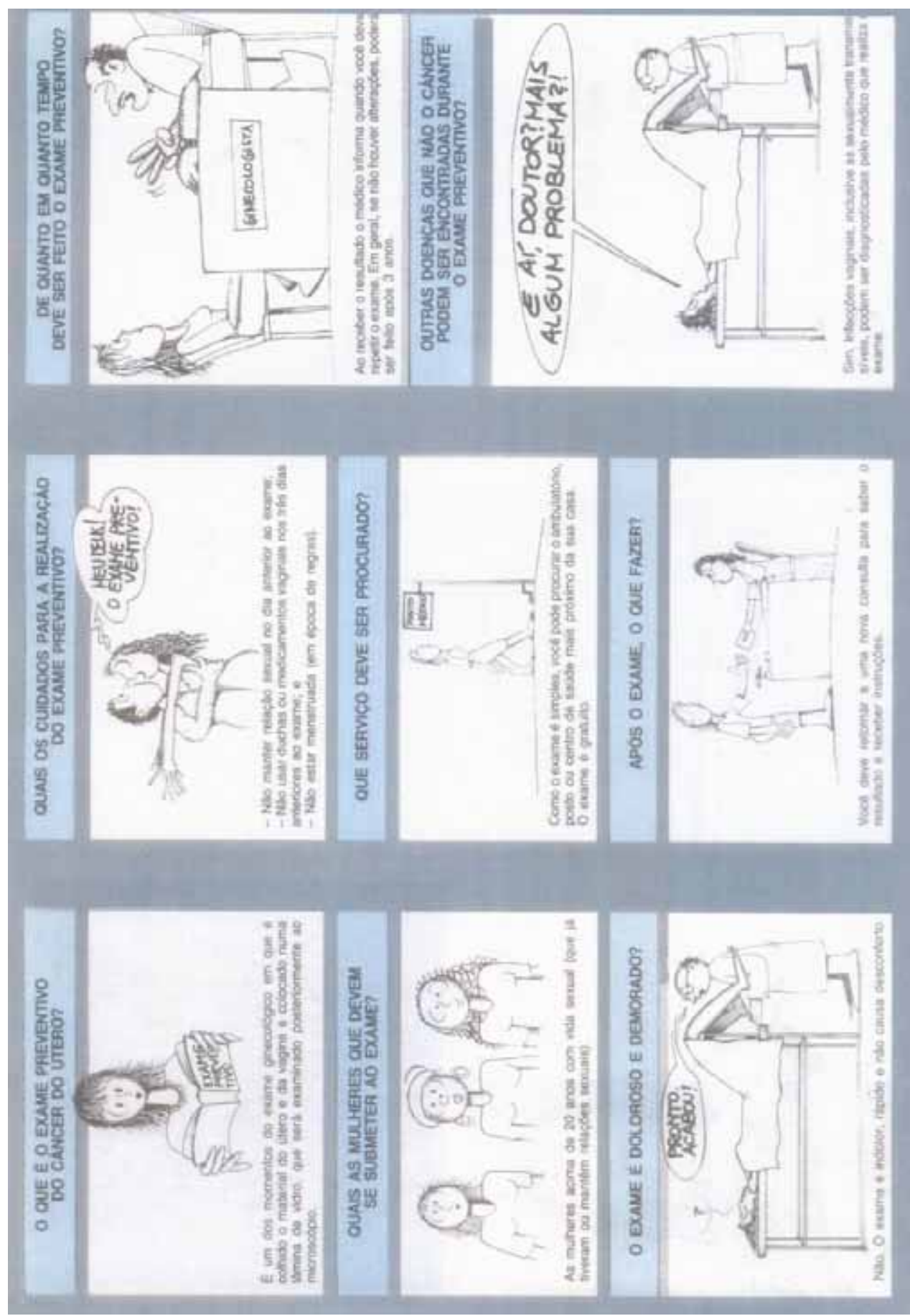

Figura 24 - Folheto 1 - verso 
$\mathrm{O}$ folheto 2 tem características muito similares às do primeiro, embora já trate de câncer de mama. O formato do papel e o recurso de desenhos esboçam uma tentativa de similaridade na identidade visual do Inca, mas nota-se que o símbolo é totalmente diferente do anterior, com um formato de emblema. O título na primeira página é "Auto-exame das mamas - Um toque de carinho"; já no verso, a frase é "Câncer de Mama - Quanto mais cedo descoberto, maiores as chances de cura."

\section{CÂNCER DA MAMA}

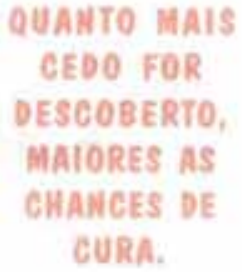

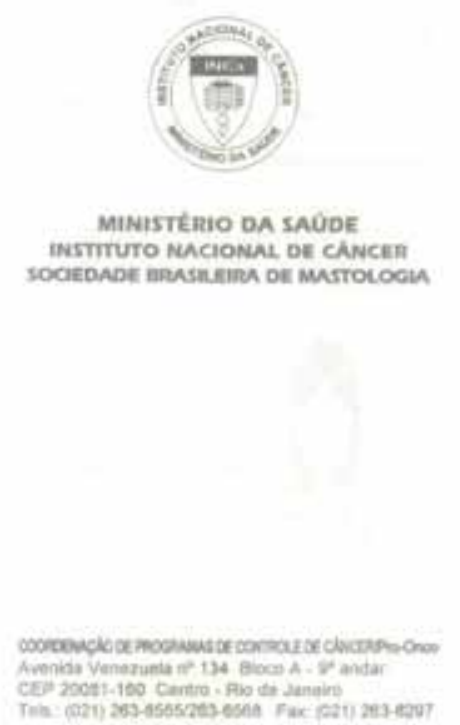

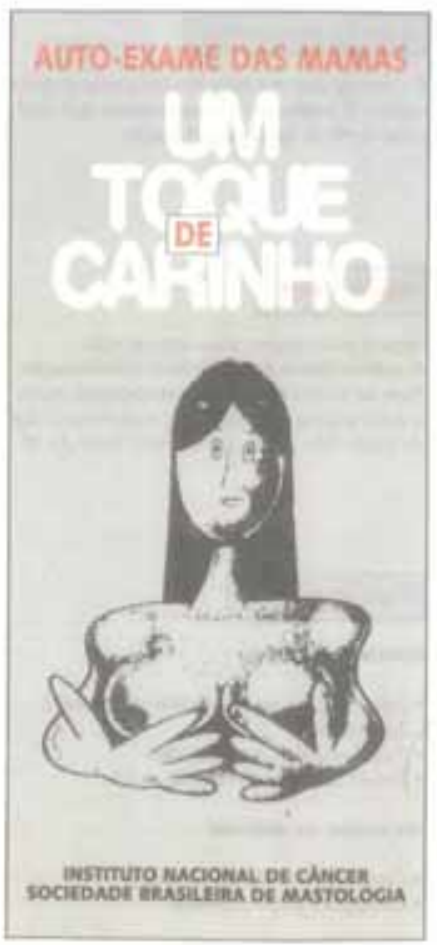

Figura 25 - Folheto 2 - frente 

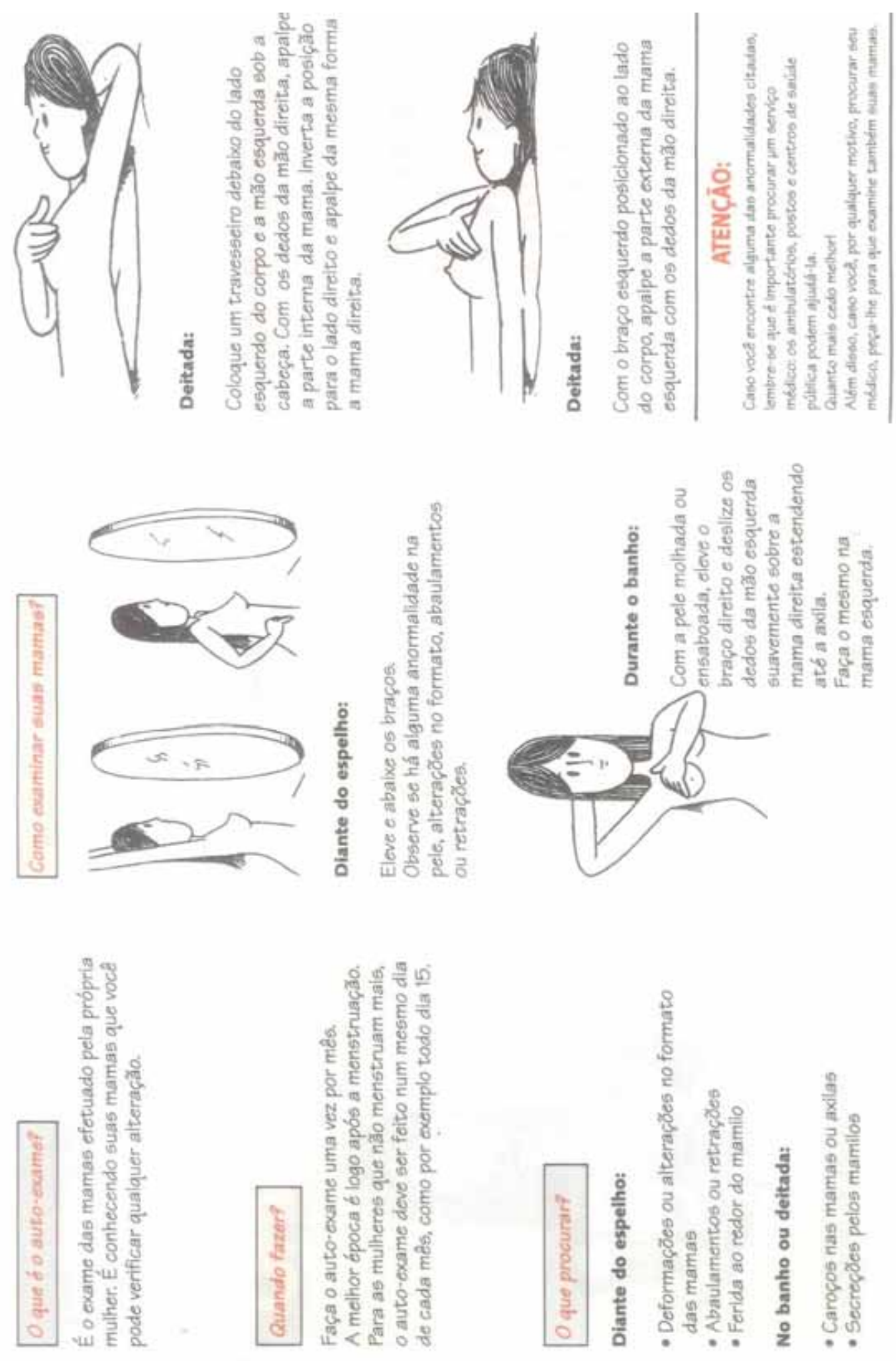

Figura 26 - Folheto 2 - verso 
O terceiro e último folheto desta primeira parte já apresenta características mais humanizadas por meio do emprego de uma mão feminina representando um seio. A cor é azul escuro, o que transmite uma sensação de seriedade e respeito em comparação ao azul bebê adotado no Folheto 1. A tipologia utilizada também aparenta modernidade e o texto utilizado no slogan: "Um toque $>>>$ Vida" faz referência à realização do auto-exame para a sobrevivência da mulher em relação à doença. $\mathrm{O}$ símbolo adotado que se encontra abaixo do timbre do Ministério da Saúde, apesar de ser levemente alterado em alguns materiais, é o que permanece atualmente utilizado pelo Inca.

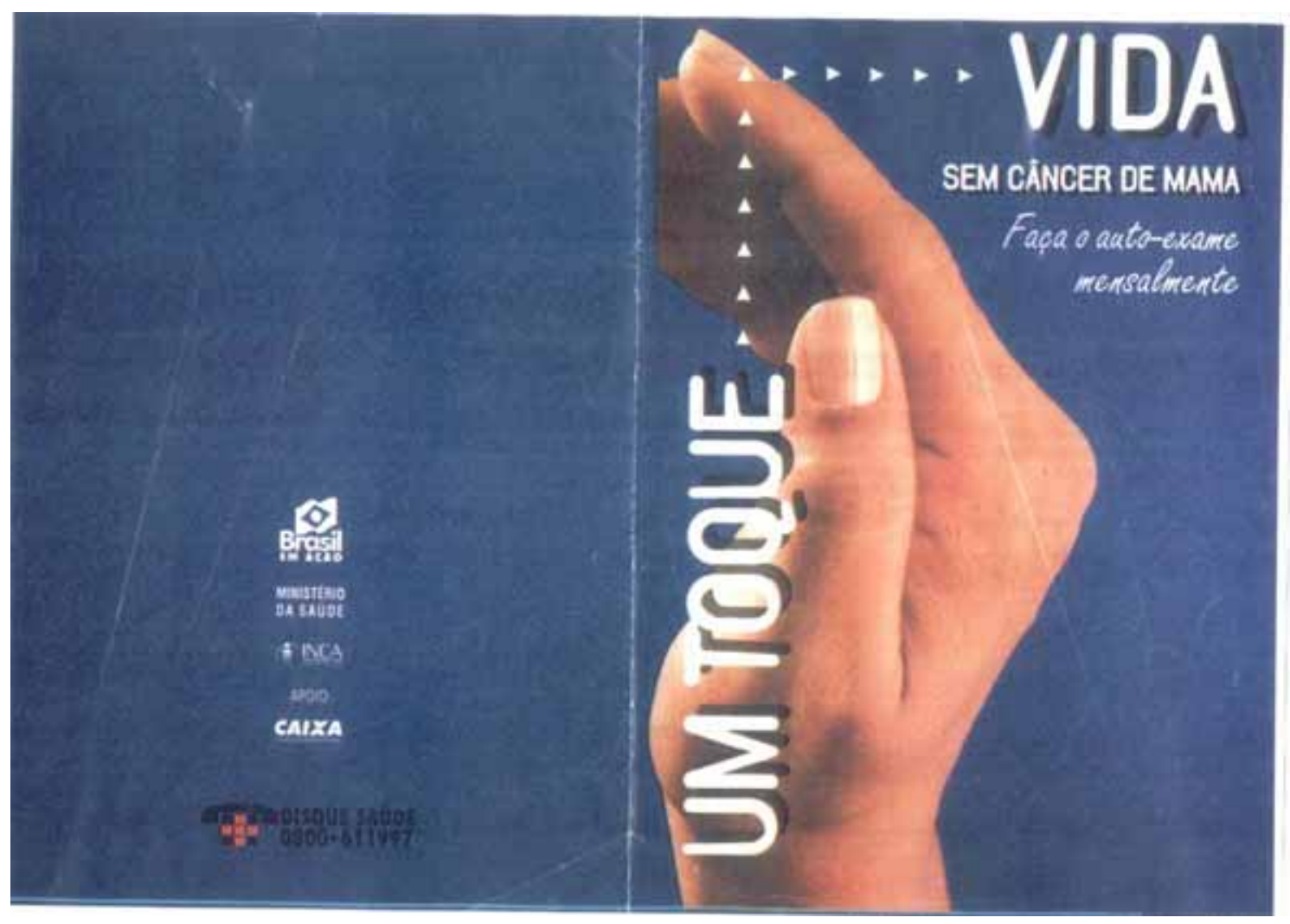

Figura 27 - Folheto 3 - frente 

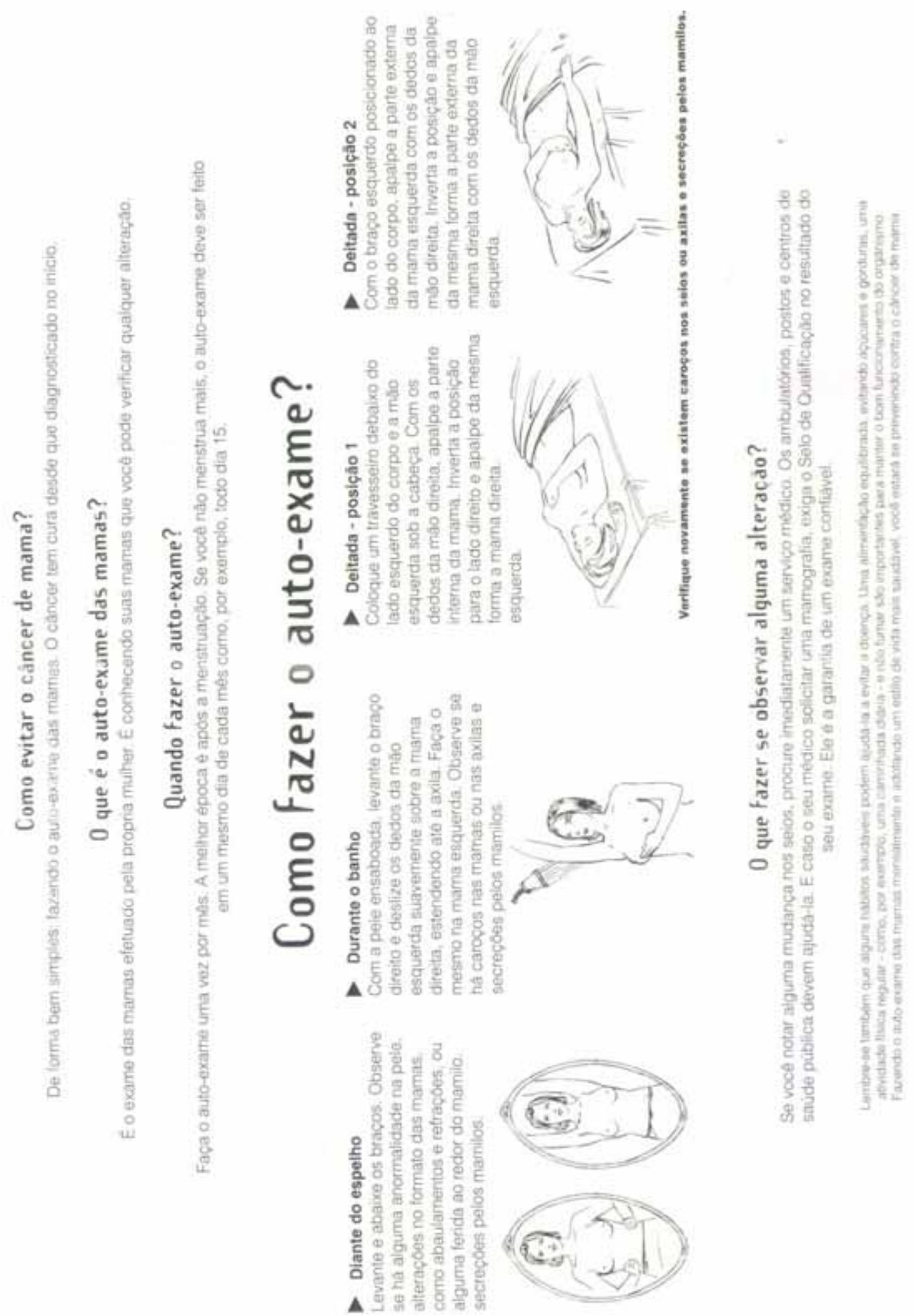

Figura 28 - Folheto 3 - verso 
Campanhas são um conjunto de ações, de esforços, para se atingir um fim determinado, em um certo período, seja isso um sucesso de vendas ou um ganho de eleições. Mas, quando se fala em prevenção de doenças, em especial das crônicas, como o câncer, os objetivos são de maior prazo. É preciso efetuar programas continuados, de grande abrangência, acompanhados de campanhas pontuais, integradas a uma lógica maior, que corrija e redirecione as suas ações. (Programa Viva Mulher - Relatório Novembro de 2000 - Metas cumpridas e novas perspectivas, INCA, p. 8)

A princípio, o foco não era o câncer de mama, época em que se adotou apenas o nome Viva Mulher - Programa Nacional de Controle do Câncer do Colo de Útero. Aliás, é possível perceber no decorrer da campanha que as abordagens sobre as duas doenças são significativamente discrepantes.

A história do Viva Mulher, como mencionado anteriormente, teve início em 1997, com a idealização de um projeto-piloto em seis localidades brasileiras: Curitiba, Brasília, Recife, Rio de Janeiro, Belém e Sergipe. Logo após, entre agosto e setembro de 1998, foi realizada a expansão nacional, denominada "Fase de Intensificação". Segundo o Inca, nesse período, foram utilizadas estratégias para estruturação da rede assistencial, e foi estabelecido um sistema de informações para o monitoramento das ações e dos mecanismos para mobilização e captação de mulheres para a realização do exame.

A partir de 1999, foi iniciada a "Fase de Consolidação", baseada na análise e reestruturação das estratégias utilizadas nas duas fases anteriores, com a inclusão das ações de controle do câncer de mama no Programa.

A estratégia de mobilização do Programa Viva Mulher visava garantir a realização de pelo menos um exame citopatológico (papanicolau) em mulheres de 35 a 49 anos. Para tal enfoque, cartazes e folhetos foram produzidos e distribuídos nas unidades assistenciais.

$\mathrm{Na}$ fase de intensificação do Programa Viva Mulher, apareceram novamente os desenhos em diferentes cores; porém, os materiais possuíam formato de folders ou livretos, com uma média de 15 a 20 páginas. Eram guias para agentes educativos ou manuais para profissionais de saúde. Cabe ressaltar a ausência da identidade visual do Inca. 


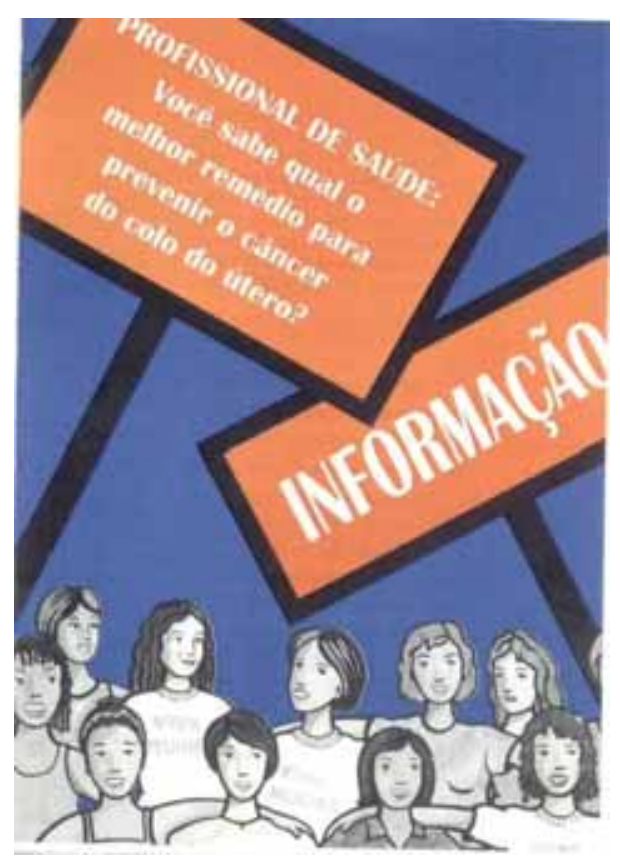

Figura 29 - Folder 1 - Capa

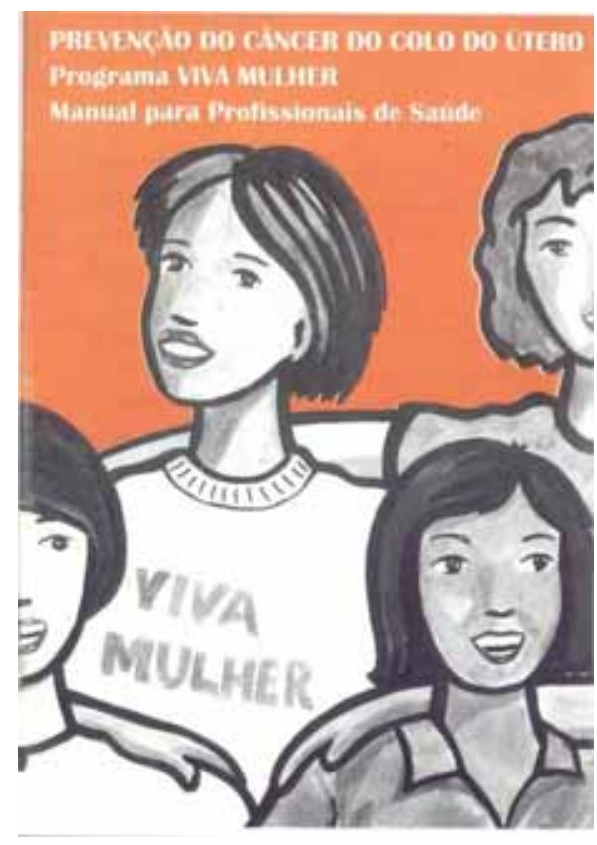

Figura 30 - Folder 2 - Capa

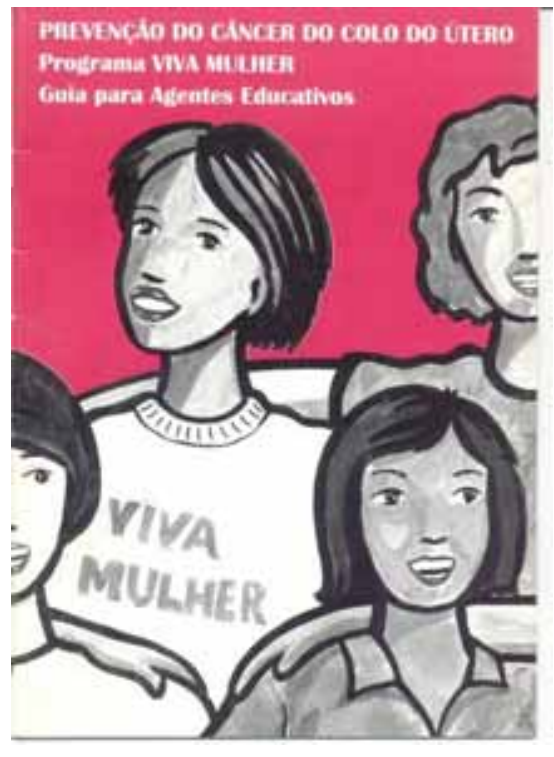

Figura 31 - Folder 3 - Capa 


\section{Iniradupoúc}

O conter de colo do ótera i umo donnce

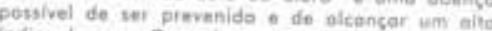
indice de cura. Contudo, no firesil, eingar um alke couse de dbetos por neoplotie nm multieres. pois

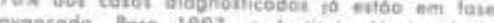

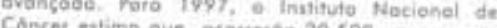

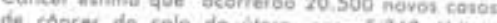
hitim sendo tolo de vierio, com 3.760 dbitos

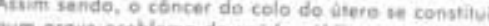
hum grove probinma de taude públice, conseachn. deatecono tbrit de totaren, dentre at eqvais

Falhas no educesao para o toud Imo pesquisa realizoda pelo roOPE, nm $199 \mathrm{~A}$

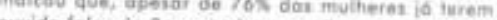
ouvido lafar do papanicotaov, ou Exome Preventive. pertan jos o haram mais de 3 vezess em sub vide Cais reiviliados apantam paro o folta de seoherit

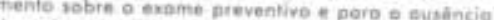

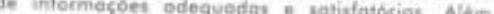

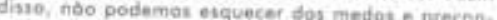
ceitos que o sociedade brasileirg ainde ttr

- Precariedode nes serviços de atendimento b saúde da mulher

Aqui podemos anymerur uno strie de problemon quan vete desde recursos meteriagi, humponos intuficiont
O Perturno da Multher na Progrome VIVA MULHIE:

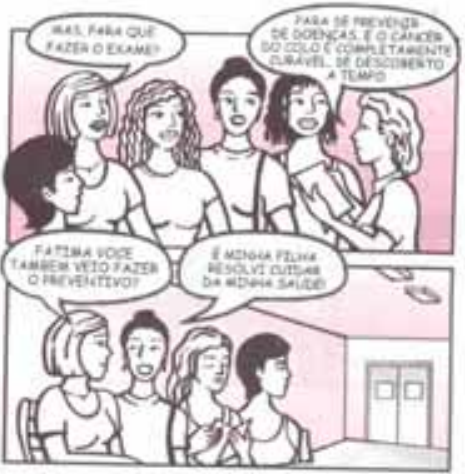

Tampos depola.

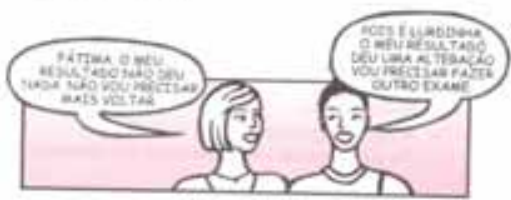

(3)

\section{Programa Viva Mulher}

Convença as mulheres, principalmente aquelas entre 35 e 49 anos de idade, a faxer o exame preventivo. Náo è possivel que um exame tóo simples e que pode salvar tantas vidas, continue sendo um ilustre desconhecido para milhares de pessoas.

- A educaçáo da comunidado e a formaçáo da equipe de saúde á a primeira garantia para o efetividade do Programo.

- Calmo, paciéncia, umo postura cuidadoso e sensivel sóo imprescindiveis tanto no momento do realizoçōo do exame, quanto no entrego dos resultados.

- E fundamental que os profissionois prestem informaçठes claras e corretas sobre os procedimentos do exame.

- Trabolhar em equipe implica em descentrolizer tarefos, dividir trabalho e poder, $e$ isto propicia moior rendimento e melhorio do qualidade, $e$ consequentemente, um menor desgoste individuol e coletivo.

Figura 32 - Exemplos de páginas interiores dos folders 1, 2 e 3 
$\mathrm{Na}$ fase de intensificação da campanha (agosto e setembro de 1998), para que se atingisse nacionalmente toda a população, adotou-se a estratégia da comunicação de massa, agregando a mídia televisiva com ações de propaganda indireta, merchandising ${ }^{48} \mathrm{em}$ programas de auditório e telenovelas, rádio, cartazes, folhetos, outdoors e intervenções urbanas.

O enfoque propulsor dessa etapa foram fitas rosa, criadas para serem amarradas nos punhos, uma associação ao ato de não esquecer compromissos ou datas importantes quando se enlaçam fitinhas nos dedos das mãos. O texto interior era "Saúde da Mulher - Prevenção do Câncer de Colo Uterino”. Segundo FARINA, PEREZ e BASTOS (2006, p. 105), “As qualidades atribuídas à cor rosa são consideradas tipicamente femininas. Simboliza o encanto, a amabilidade. Remete à inocência e frivolidade. Feminino."

Segundo dados do Inca, a estratégia da campanha utilizou diversos meios de comunicação, com base principalmente no rádio e na televisão, com duas finalidades: mobilizar e debater. "A sustentação da campanha nas ruas foi composta por 11 milhões de fitinhas de pulso, cartazes e folhetos (...) Outdoors duplos (375 pontos) nas capitais brasileiras e intervenções urbanas com fitas cor-de-rosa gigantes enlaçando diversos monumentos e prédios públicos (...).”

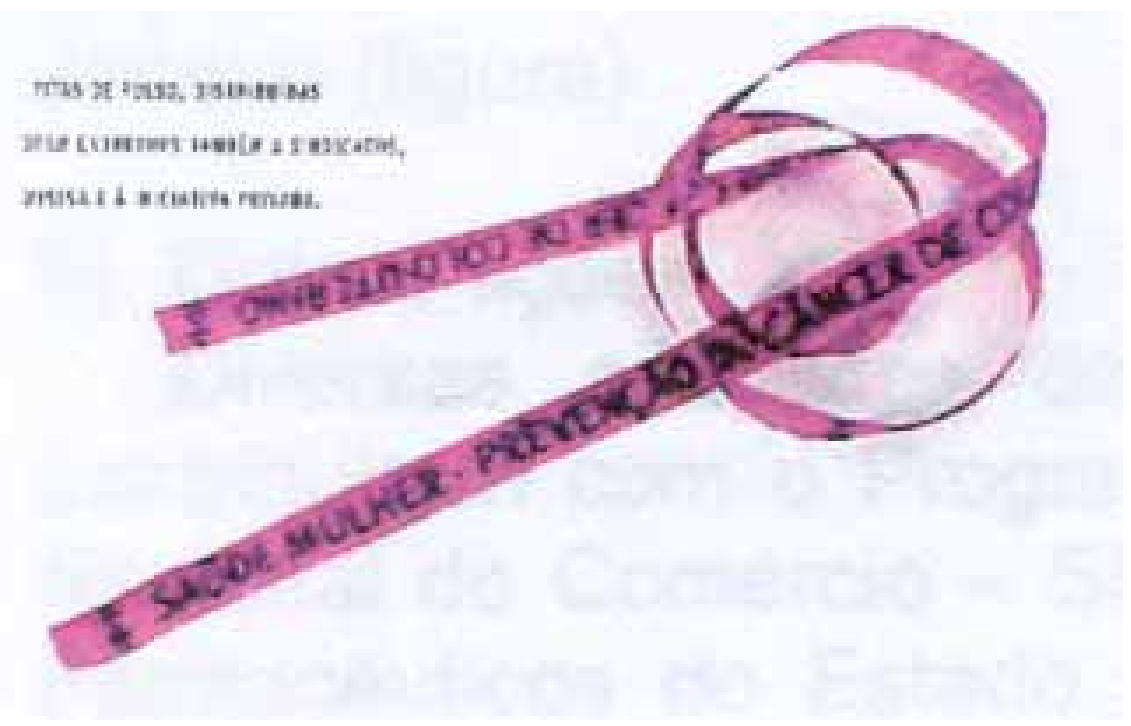

Figura 33 - fita cor-de-rosa da campanha do Programa Viva Mulher

\footnotetext{
48 Embora haja discussões sobre a definição de merchandising, sua definição mais popular é: conjunto de ações de Marketing realizadas com produtos ou serviços que tem como objetivo final a venda de outro produto. Há também o Merchandising editorial, com inserções de produtos/serviços em programas de TV, também conhecido como Tie-in.
} 


\subsection{1 - Televisão}

A televisão se define como um veículo de massa de longo alcance por meio de um culminante poder sinestésico na junção dos sentidos auditivos e visuais. A TV emociona, oferecendo ao telespectador uma oportunidade de co-participar de suas imagens reais, técnicas, composição de cenas e muito mais, criando intimidade e apreensão de valores com relação à mensagem transmitida.

É por intermédio de suas imagens que a televisão estabelece vínculos com seu público. No Brasil e em alguns outros países, existe uma carência de divulgação sobre a história de seus heróis e de personalidades nacionais em destaque fora do âmbito televisivo; tal ausência de divulgação acaba transferindo aos artistas da sociedade de massa um caráter de referência para a cultura popular. No caso do câncer de mama, a produção não fugiu à regra com a criação de dois tipos de comerciais, um de 60 segundos e outro de 30 segundos, ambos com a participação da atriz Eva Wilma e de diversos artistas brasileiros (vide anexo Inca - II).

A escolha da utilização da atriz foi em decorrência de seu personagem interpretado no seriado ficcional produzido e exibido no Brasil pela Rede Globo, Mulher, entre os anos de 1998 e 1999. Eva Wilma era a médica Martha Corrêa e trabalhava em uma clínica especializada de saúde feminina, envolvendo-se nos dramas de variadas pacientes, tais como: mulheres violentadas por abortos (clandestinos), adolescentes grávidas, etc.

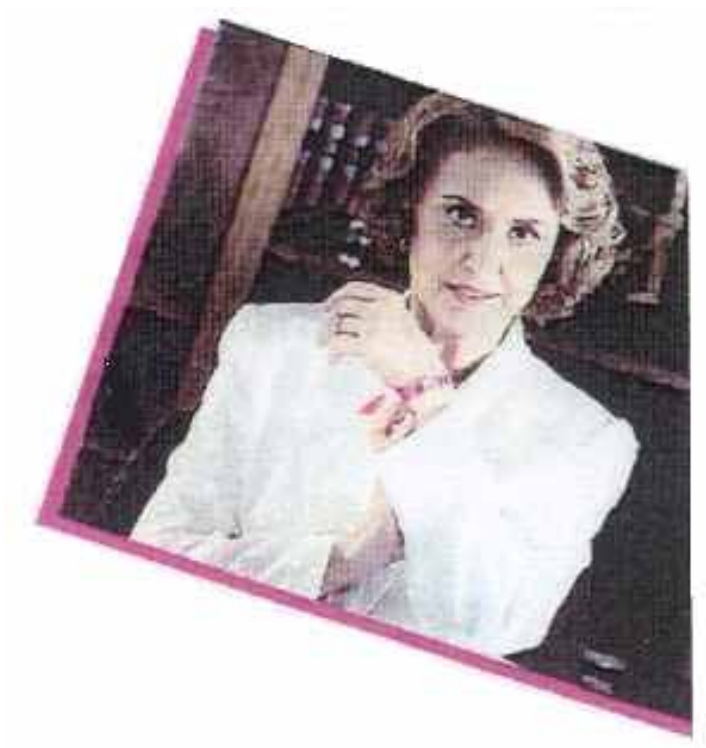

Figura 34 - Cena do comercial veiculado sobre a campanha do Programa Viva Mulher A roupa escolhida para a personagem é branca na tentativa de recorrer à imagem médica da atriz 


\section{- Descritivo do comercial de TV - 60 segundos:}

Cena I - Eva Wilma fala para a câmera enquanto coloca a fitinha no pulso:

"Esta fitinha aqui é para lembrar você de uma coisa muito importante. Ela é o símbolo da prevenção do câncer de colo de útero. Uma doença que mata uma mulher a cada 1 hora e 20 minutos no Brasil, mas que é tão fácil de curar quando descoberta a tempo. Por isso, lembre sua mãe, sua irmã, sua filha, lembre alguém que você queira bem."

Cena II- Corta para cenas de mulheres sendo atendidas nos postos de saúde.

Locução em off ${ }^{49}$ :

O Ministério da Saúde, as Secretarias da Saúde lembram:

"Não deixe de fazer a prevenção do câncer de colo uterino se você nunca fez o exame e tem de 35 a 49 anos".

Cena III - A atriz volta à câmera em close e diz:

"Fazer o exame não custa nada. Não fazer pode custar uma vida."

Locução em off:

“Até 19 de setembro, em todo o Brasil, vá a uma unidade de saúde.”

Vinheta - Assinatura: Saúde da Mulher/Ministério da Saúde

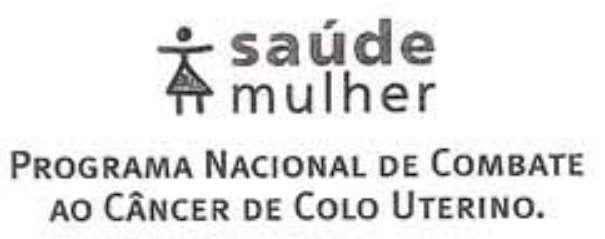

${ }^{49}$ A locução em off é basicamente um texto do comercial interpretado por locutor/intérprete que não aparece em cena. 


\section{- Descritivo do comercial de TV - 30 segundos:}

Cena I - Personalidades mostram a fitinha amarrada no pulso, alertando para que não se esqueçam do exame preventivo do câncer de colo uterino.

O áudio transmite o seguinte jingle:

Fale com alguém

Convença alguém

Lembre alguém

Que você queira bem

Sua mãe, sua irmã

Sua amiga ou mulher

Lembre todas elas

Lembre quem você puder

Locução em off:

O Ministério da Saúde, as Secretarias de Saúde lembram:

Não deixe de fazer a prevenção do câncer de colo uterino

se você nunca fez o exame e tem de 35 a 49 anos.

Fazer o exame não custa nada,

Não fazer pode custar uma vida.

Até 19 de setembro, em todo o Brasil,

vá a uma unidade de saúde.

Vinheta - Assinatura: Saúde da Mulher/Ministério da Saúde

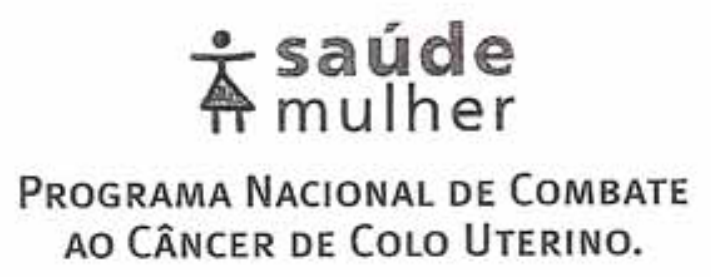




\subsection{2 - Rádio}

Assim como na televisão, ocorreram duas formas de abordagem por meio de grandes redes nacionais de rádio. Na primeira, um jingle cantando por Herbert Vianna, líder da banda Paralamas do $\mathrm{Sucesso}^{50}$; o texto era idêntico ao do comercial de 30 segundos.

Nota-se na linguagem coloquial e rima fácil o intuito de assimilação dos ouvintes para a campanha. A voz escolhida foi a de um cantor com forte inserção no gosto popular e poder de lembrança entre o público.

As orações foram trabalhadas para que a mensagem fosse incorporada por todos. $\mathrm{O}$ homem poderia ajudar lembrando alguma mulher próxima também. "Fale com alguém. Convença alguém. Lembre alguém. Que você queira bem.” Na locução em off, o texto é imperativo, representa poder e objetiva uma caracterização de dever da mulher perante o exame: "Não deixe de fazer a prevenção do câncer de colo uterino. Se você nunca fez o exame e tem de 35 a 49 anos, até 19 de setembro, em todo o Brasil, vá a uma unidade de saúde.", "Você tem que....", "Salve...", entre outros. Além da representação do ditado popular, recorrendo à sabedoria e aos bons conselhos criados pela identidade nacional: "Melhor prevenir do que remediar - Sua vida está em jogo".

$\mathrm{Na}$ segunda abordagem, os próprios locutores e apresentadores radialísticos de AM realizaram, em meio aos depoimentos diários de seus programas, a discussão do tema junto à população em nove diferentes comerciais de rádio. Nota-se na transcrição dos comerciais um apelo muito mais significativo nas últimas divulgações, com um caráter de responsabilidade para todos: homens, mulheres, mães, filhas, filhos, amigos, entre outros.

\section{Transcrição:}

\section{I - "Prevenção"}

Todos conhecem o ditado "antes prevenir do que remediar". Muitas doenças podem ser evitadas com cuidados básicos. Outras podem ser curadas se forem descobertas cedo. Esse é o caso do câncer de colo de útero. Com um simples exame chamado papanicolau é possível descobrir se a doença existe e fazer o tratamento para a cura. É por isso que o Ministério da Saúde e as Secretarias Estaduais e Municipais de Saúde estão realizando o Programa Nacional

\footnotetext{
${ }^{50}$ Os Paralamas do Sucesso é uma das mais conhecidas bandas de rock brasileiro, idealizada na década de 70, na cidade do Rio de Janeiro.
} 
de Combate ao Câncer Uterino. Até 19 de setembro, todas as mulheres que têm entre 35 e 49 anos e que nunca fizeram o exame devem procurar uma unidade de saúde para fazê-lo de graça. O exame não dói e não tem efeitos colaterais.

Lembre-se de fazer o exame e lembre também alguém que você queira bem. É até o dia 19 de setembro em qualquer unidade de saúde. Fazer o exame não custa nada. Não fazer pode custar uma vida.

\section{II - "Estatística"}

A cada ano, de seis a sete mil mulheres morrem no Brasil vítimas do câncer de colo de útero. Diminuir esse número depende de todos nós. O câncer de colo de útero pode ser completamente curado se for descoberto cedo. Para isso é necessário um exame preventivo chamado papanicolau. Esse exame pode ser feito de graça até o dia 19 de setembro por todas as mulheres entre 35 e 49 anos que nunca fizeram o exame antes.

Converse com pessoas que você conhece sobre o exame de prevenção ao câncer de colo de útero. O Brasil inteiro está unido nessa campanha. Lembre-se de fazer o exame e lembre também alguém que você queira bem. Basta ir até 19 de setembro a qualquer unidade de saúde. Fazer o exame não custa nada. Não fazer pode custar uma vida.

$$
\text { III - "Como, quando, onde" }
$$

O Brasil inteiro está unido na campanha para a prevenção do câncer de colo de útero, uma doença que pode ser fatal se não for descoberta e tratada cedo. Toda mulher entre 35 e 49 anos que nunca fez o exame preventivo deve procurar uma unidade de saúde para fazer esse exame de graça até o dia 19 de setembro. Não dói, não traz nenhum efeito colateral e não é demorado.

Para fazer o exame preventivo é importante não ter relações sexuais no dia anterior e nem estar no período menstrual. Quem está grávida deve fazer o exame, já que não existe nenhum risco para a mulher e nem para o bebê. Tão importante quanto fazer o exame é pegar o resultado e, se necessário, seguir rigorosamente o tratamento. 
Lembre-se de fazer o exame e lembre também as pessoas que você conhece. Fazer o exame não custa nada. Não fazer pode custar uma vida.

\section{IV - "Mobilização"}

O que você faz quando não pode esquecer uma coisa de jeito nenhum? Amarra uma fitinha no pulso? Pois é isso mesmo que você deve fazer para se lembrar do exame de prevenção do colo de útero.

Até o dia 19 de setembro as unidades de saúde em todo o país estarão realizando o exame de graça para todas as mulheres entre 35 e 49 anos e que nunca fizeram isto antes.

O câncer de colo de útero é uma doença que pode ser fatal, mas tem cura se for descoberta no início. É por isso que você deve se lembrar e lembrar também as pessoas que você gosta, na sua casa, no trabalho, na sua comunidade. Faça como milhares de mulheres brasileiras que estão amarrando uma fitinha cor-de-rosa no pulso para não se esquecerem do exame.

É até o dia 19 de setembro. Fazer o exame não custa nada. Não fazer pode custar uma vida.

\section{V - "Convocação"}

O Brasil inteiro está mobilizado para prevenir e curar uma doença que pode ser fatal, o câncer de colo de útero. Assim como a maioria das doenças, o câncer de colo uterino pode ser prevenido e, se tratado no início, pode ser totalmente curado. A cada ano, de seis a sete mil mulheres morrem no Brasil vítimas desse câncer. Diminuir esse número depende de todos nós.

Até 19 de setembro, todas as mulheres que têm entre 35 e 49 anos que nunca fizeram o exame devem fazê-lo em qualquer unidade de saúde. É de graça.

Lembre-se de fazer o exame e lembre também as pessoas que você conhece, na sua família, sua rua, seu trabalho e sua comunidade. Fazer o exame não custa nada. Não fazer pode custar uma vida.

VI - "Compromisso" 
Atenção, você que é mulher, tem entre 35 e 49 anos e nunca fez um exame preventivo de câncer de colo de útero, o papanicolau, fique ligada.

Fique ligada. Até o dia 19 de setembro todas as unidades de saúde estarão fazendo esse exame preventivo de graça. Reserve um horário do seu dia para fazer o papanicolau. Não dói, não é demorado e não tem nenhum efeito colateral. Mesmo quem está grávida deve fazer o exame. Não há risco para a mãe e nem para o bebê.

Converse com as pessoas que você conhece sobre o exame de prevenção. Lembre-se de fazer o exame e lembre também quem você quer bem. Fazer o exame não custa nada. Não fazer pode custar uma vida.

$$
\text { VII - "Últimos dias" }
$$

Você ainda não fez o exame de prevenção ao câncer de colo uterino? O que você está esperando? Até o final do mês de setembro você pode fazer esse exame em qualquer unidade de saúde sem pagar nada.

Por favor, não brinque com sua saúde. O câncer de colo de útero é uma doença séria que mata milhares de mulheres todo ano no Brasil, mas que tem cura se for descoberta logo cedo. Para se prevenir você tem que fazer esse exame chamado papanicolau, que não dói e não traz nenhum desconforto.

Sua saúde é o que mais importa. Fale com suas amigas, com todas as mulheres de sua família sobre a importância da prevenção. Não deixe de lado esse compromisso. Vá até a unidade de saúde mais próxima. O Brasil inteiro está unido nessa luta contra o câncer de colo uterino. Fazer o exame não custa nada. Não fazer pode custar sua vida ou a de quem você ama.

\section{VIII - "Contagem regressiva"}

Ainda dá tempo de fazer de graça o exame de prevenção ao câncer de colo uterino. Essa é uma doença muito séria que mata de seis a sete mil mulheres no Brasil a cada ano. Vamos acabar com essa tristeza. Até o fim do mês de setembro você pode fazer o exame de prevenção sem pagar nada em qualquer unidade de saúde. Não deixe de lado esse compromisso. É a sua vida que está em jogo. O câncer de colo de útero pode ser totalmente 
curado se for descoberto logo no início. Por isso, é necessário fazer o exame o quanto antes. O exame não dói e não tem nenhum desconforto.

Então, o que você está esperando?

Vamos lá! Vá hoje mesmo até a unidade de saúde mais próxima para se prevenir contra o câncer de colo uterino.

Fazer o exame não custa nada. Não fazer pode custar sua vida ou a de quem você ama.

\section{IX- "Responsabilidade da Família"}

Amigo ouvinte. Você tem que proteger a vida de todas as mulheres que estão ao seu lado. Oriente para que toda mulher faça o exame de prevenção ao câncer de colo uterino.

Essa é uma doença que mata milhares de mulheres no Brasil, mas que pode ser curada se for descoberta cedo.

Por isso, o Ministério da Saúde está convocando todas as mulheres para fazer o exame de graça, até o fim do mês de setembro, em qualquer unidade de saúde.

Alertar sua esposa, mãe, filha, amiga é sua obrigação. Salve a vida de quem você ama. Não deixe de lado esse compromisso. O Brasil inteiro está unido nessa luta contra o câncer de colo uterino e o mais importante é sua atitude. Fazer o exame não custa nada. Não fazer pode custar sua vida ou a de quem você ama. 


\subsection{3 - Cartazes e folhetos}

Os cartazes e folhetos possuem uma composição centralizada e um conjunto cromático com a predominância de cores fortes: preto e vermelho, o que remete a uma característica de sobriedade à situação, diferente da linha criativa adotada para os primeiros folhetos do Inca desenhos de garotas jovens.

Nota-se, apesar das características gráficas, que as personagens escolhidas, mulheres de aproximadamente 40 anos, estão com uma feição otimista, fato que desmistifica a situação problemática da doença, colabora com a aceitação social para o assunto e aproxima as mulheres dentro do universo do público-alvo para a campanha.

A produção de cartazes para a campanha foi remetida às Secretarias Estaduais e Municipais de Saúde que, por sua vez, repassaram-nos para as unidades de saúde de suas regiões. Foram impressos 1,5 milhão de cartazes para distribuição em todo o Brasil.

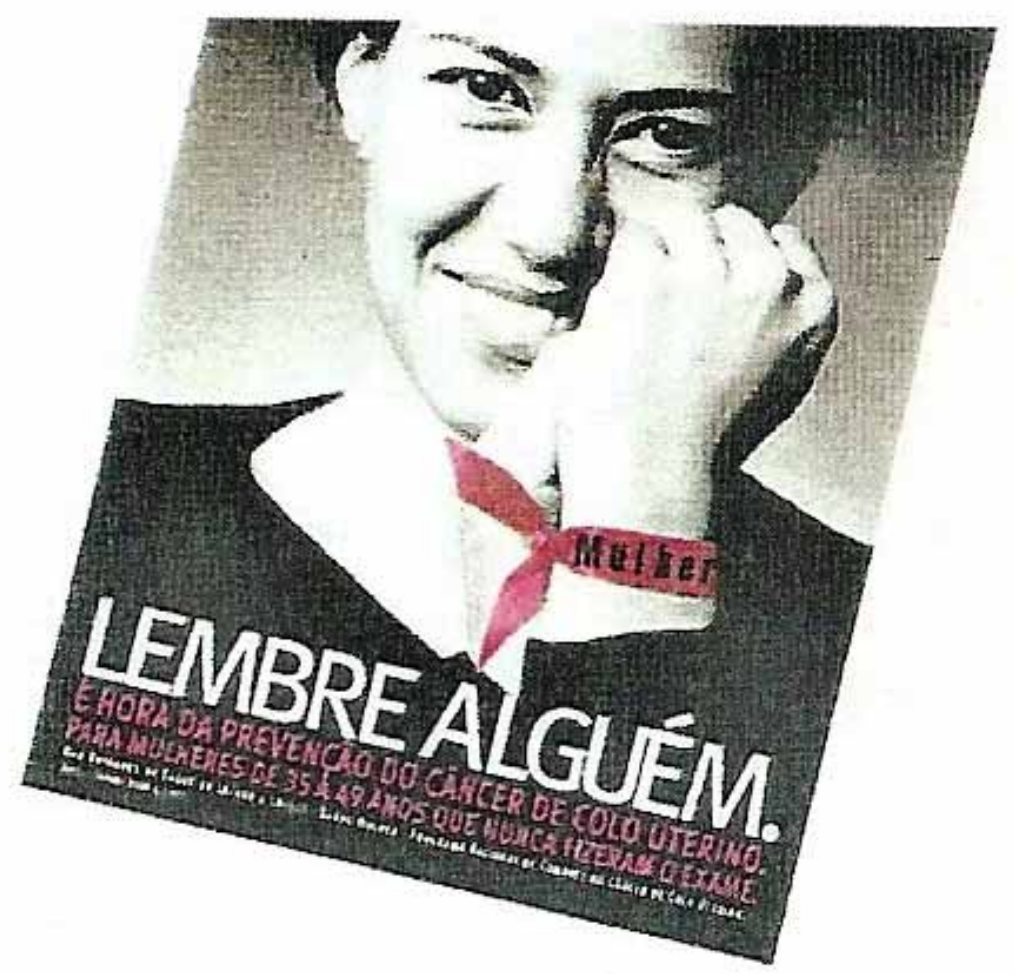

Figura 35 - Cartaz da campanha do Programa Viva Mulher 
Os folhetos foram produzidos em dois formatos distintos, com tiragem de 4,1 milhões de exemplares, distribuídos nos mesmos pontos dos cartazes. O formato menor, volante, foi divulgado posteriormente, com uma produção de cerca de 1 milhão de exemplares.

A tiragem dos cartazes foi mais adequada à repercussão de uma campanha dessa magnitude devido ao potencial de mulheres que estes poderiam atingir com apenas um exemplar, se bem localizado. Entretanto, o número de folders e volantes foi extremamente irrisório diante do aumento considerável da população feminina no Brasil no final do século XX. Conforme os dados do IBGE, em 1980, eram 98,7 homens para cada 100 mulheres, proporção que caiu para $97 \%$ em $2000 .^{51}$

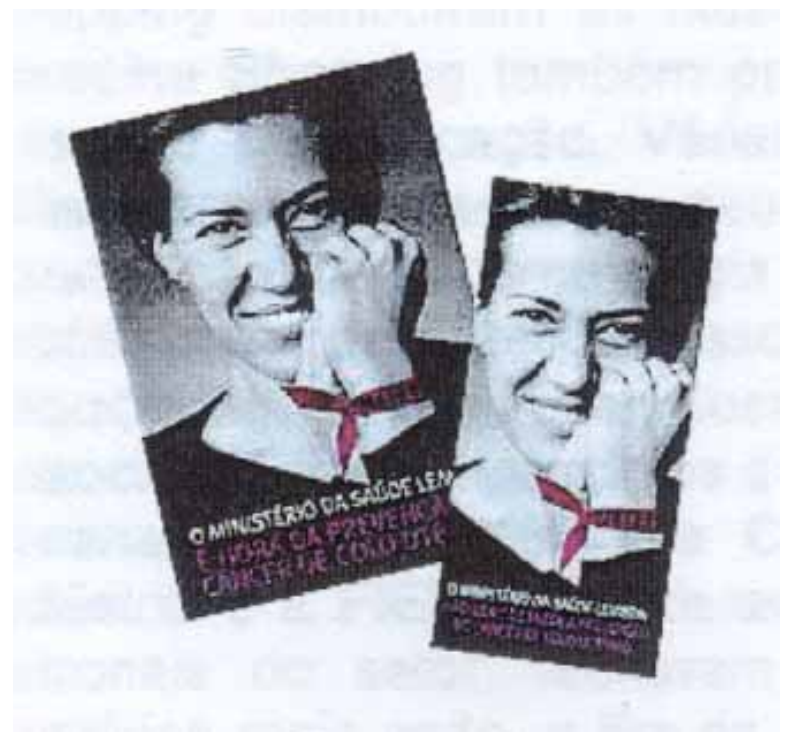

Figura 36 - Folhetos da campanha do Programa Viva Mulher

Para os profissionais de saúde também foram produzidos dois modelos de cartazes, que foram definidos como motivacionais e de orientação técnica da coleta para o exame, ambos com tiragem de 100 mil exemplares. A produção de folders também alcançou o mesmo número de distribuição. Todo o material foi encaminhado às unidades de saúde do Brasil.

\footnotetext{
${ }^{51} \mathrm{http}$ //www.ibge.com.br/home/presidencia/noticias/noticia_visualiza.php?id_noticia=207\&id_pagina=1
} 

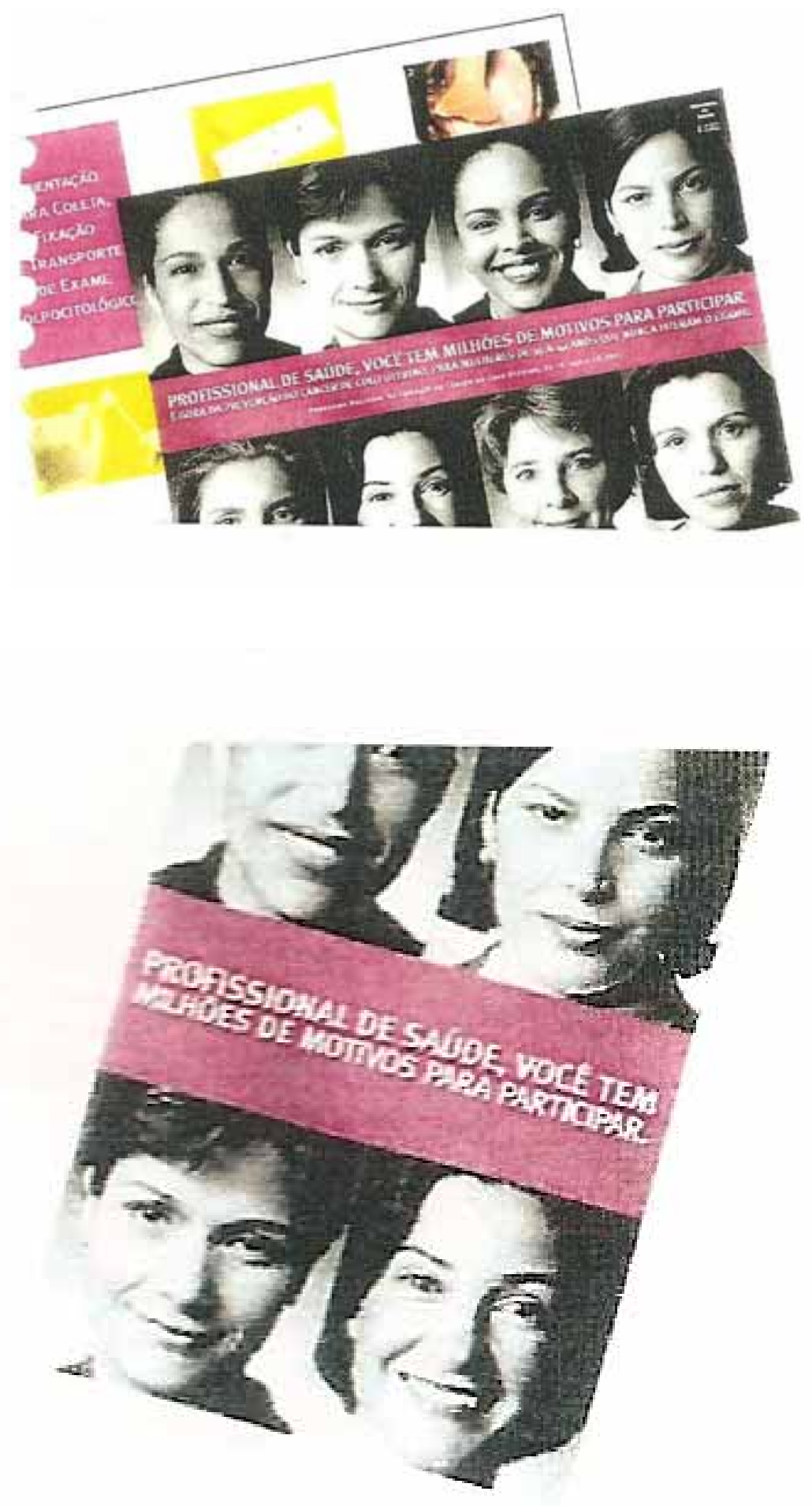

Figura 37 - Folders para profissionais de saúde da campanha do Programa Viva Mulher 
4.3.4 - Outdoors e intervenções urbanas

Compostos por quatro títulos diferentes, os outdoors realizaram uma cobertura nacional, com 375 pontos distribuídos por todas as capitais brasileiras. Nas cidades de São Paulo, Belo Horizonte, Rio de Janeiro, Porto Alegre, Salvador e Brasília, a estrutura de sustentação do outdoor foi envolvida por uma fita cor-de-rosa, o que correspondeu a $55 \%$ da produção total.

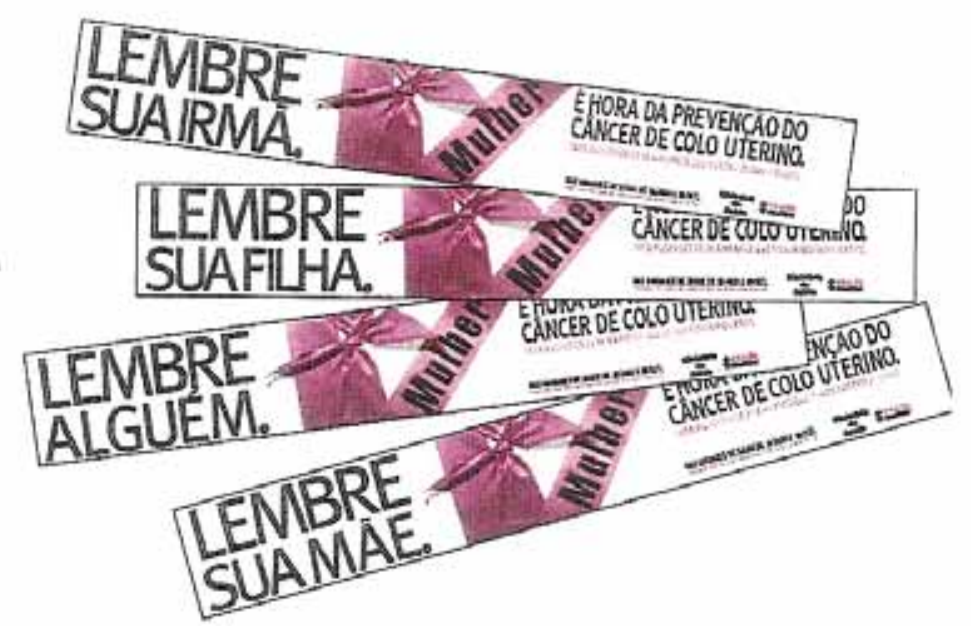

Figura 38 - Outdoors da campanha do Programa Viva Mulher

A campanha optou também por enlaçar a fita cor-de-rosa em monumentos e prédios públicos em diversas cidades brasileiras, como por exemplo, no bondinho do Pão de Açúcar no Rio de Janeiro, no elevador Lacerda em Salvador, no obelisco da Praça Sete em Belo Horizonte, na ponte do rio Guaíba em Porto Alegre e no Viaduto do Chá em São Paulo. Telejornais e veículos da mídia impressa realizaram matérias sobre tais intervenções, o que amplificou a ação. 


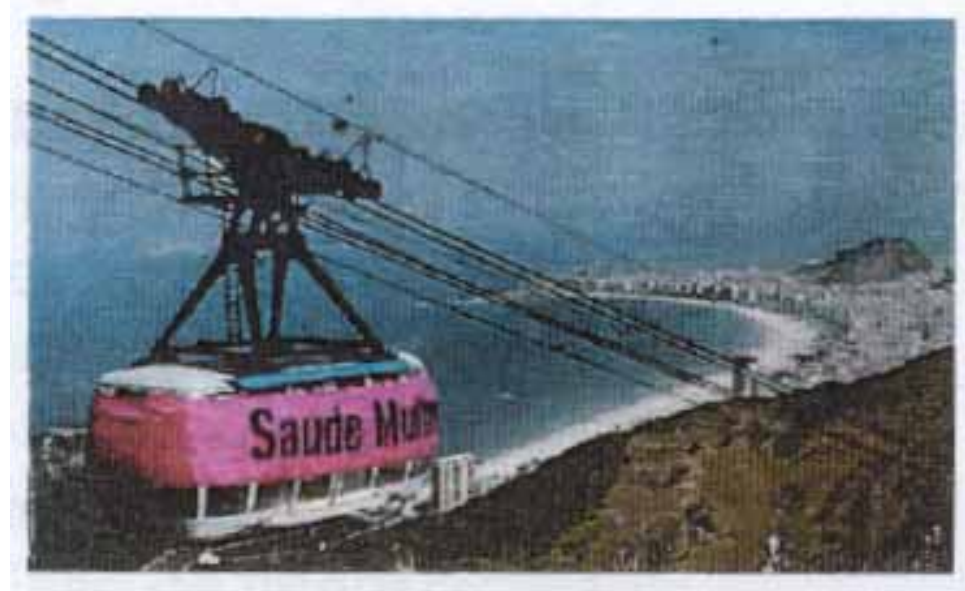

Figura 39 - Intervenções urbanas da campanha do Programa Viva Mulher

\subsection{5 - Propagandas de apoio}

Segundo informações do Inca, diversas entidades da sociedade civil organizada e da iniciativa privada contribuíram com a campanha. As Lojas Americanas e a rede de hipermercados Carrefour distribuíram as fitas de pulso e volantes ao seu público. O Teresina Shopping, além desses materiais, produziu um back light ${ }^{52}$ com a imagem do cartaz da campanha.

O Serviço Social do Comércio - Sesc, o Serviço Nacional de Aprendizagem Comercial - Senac e o Sindicato do Comércio Varejista de Produtos Farmacêuticos no Estado de São Paulo - Sincofarma-SP produziram banners cujo intuito era afixá-los nas sedes das instituições e nas farmácias do Estado de São Paulo. Associações de cosmetologia, como Associação de Cosmetologia e Estética do Ceará, Associação Alagoana dos Profissionais da Estética, Associação de Estética, Cosmetologia e Maquiladores do Rio Grande do Sul, Associação dos Empresários de Estética do Rio Grande do Sul e Associação Paranaense de Estética e Cosmetologia também enviaram materiais a seus membros participantes.

Faz-se importante mencionar que órgãos como a Confederação Nacional da Indústria CNI e a Federação das Indústrias do Estado de São Paulo - Fiesp acordaram com suas operárias um dia de término de serviço mais cedo do que o convencional da jornada de trabalho para que estas pudessem se dirigir às unidades de saúde.

\footnotetext{
52 Propaganda de mídia exterior em que a luz é colocada atrás da mensagem.
} 


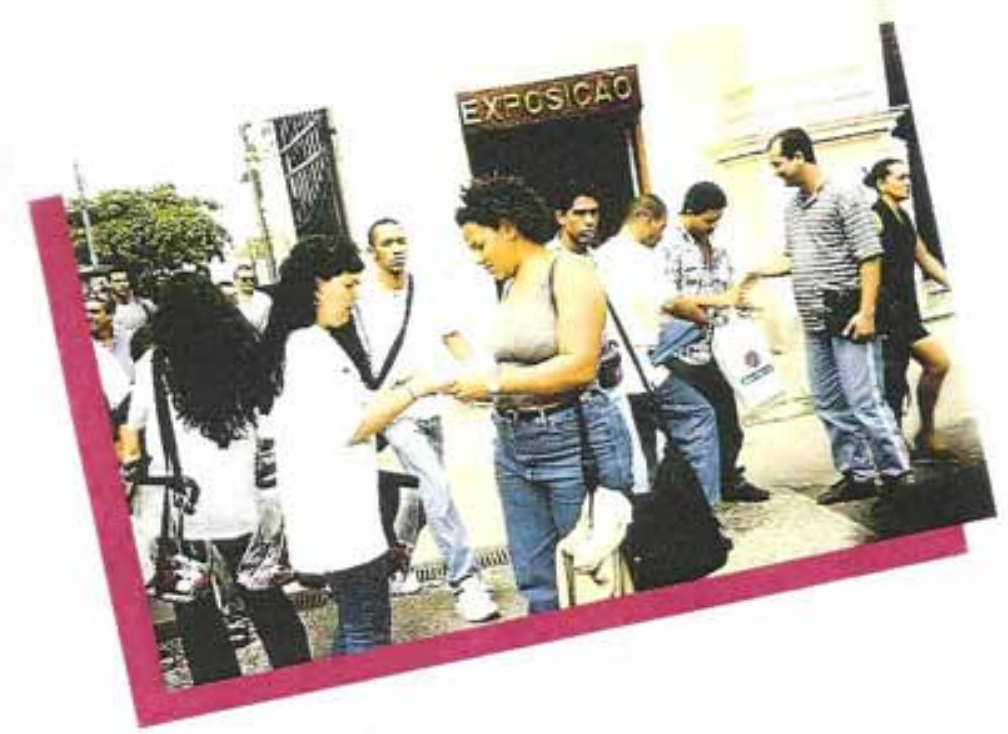

Figura 40 - Ponto de distribuição de fitas cor-de-rosa da campanha do Programa Viva Mulher

\subsection{6 - Resultados da Campanha}

Nos materiais recebidos pelo Inca, existem inúmeros dados sobre tal campanha de publicidade que corresponde à fase de intensificação do Programa Viva Mulher. O Ministério da Saúde realizou uma pesquisa para avaliar o recall desta entre os dias 3 e 4 de setembro de 1998 junto à população. Nas definições da época, os traços de identidade estabelecidos para o corpus foram: mulheres de 30 anos ou mais, das classes $\mathrm{C} / \mathrm{D} / \mathrm{E}$, com acesso a telefones em casa ou no trabalho. Cabe ressaltar que a divisão por classe no Brasil, hoje, mudou perante um crescimento de 86,2 milhões de pessoas pertencentes à classe $\mathrm{C}$, sendo esta a maioria da população, com participação de $46 \%$ na sociedade. Para a categorização levou-se em consideração a posse de bens, nível educacional e a renda média.

Foram realizadas 400 entrevistas no Estado de São Paulo e 200 no Estado de Pernambuco, das quais concluiu-se que $95 \%$ das entrevistadas comentaram ter visto ou escutado a campanha de prevenção do colo de útero. Os meios mais lembrados foram televisão, $86 \%$, e rádio, $25 \%$, e os relatórios frisam ainda um índice de $98 \%$ das entrevistadas que declararam ter gostado, ou adorado a campanha.

A meta da campanha de câncer de colo uterino era realizar 4 milhões de exames durante os meses de agosto e setembro de 1998, e o número final divulgado pelo Ministério 
da Saúde foi 3,1 milhões. Tal resultado, ao ser comparado com a antiga média de 550 mil divulgados anteriormente ao início da campanha, demonstrou um crescimento de $263,6 \%$ de exames de papanicolau.

Segundo o Relatório Novembro de 2000 - Metas Cumpridas e Perspectivas, "Isso significa que, apesar da meta estipulada não ter sido atingida, o resultado da campanha é bastante significativo. Em dois meses o Programa Nacional de Combate ao Câncer de Colo de Uterino conseguiu elevar em mais que o dobro o número de exames de papanicolau; e, como detectado na pesquisa, a comunicação teve papel fundamental."

Porém, segundo o relatório elaborado pelo Inca, Metas Cumpridas e Novas Perspectivas do Programa Viva Mulher, o objetivo não foi totalmente alcançado devido aos erros de etapas processuais sobre o arquivo de dados, gerando perda de informações, com um fluxo de envio de disquetes centralizado no Ministério da Saúde.

O treinamento para preenchimento dos formulários e digitação no aplicativo do sistema de informática também não ocorreu, implicando em perda de qualidade dos dados. Um sistema de crítica para a duplicidade ou multiplicidade de entradas no banco de dados do SISCOLO, também não havia sido previsto, gerando algumas vezes, dados múltiplos da mesma mulher. (2000, p. 72)

Todavia, quanto à eficácia das ações de publicidade, os dados de recall divulgados no relatório do Inca e computados pela Marketing, Estratégia e Comunicação Institucional - MCI sobre a memorização e opinião de mulheres entrevistadas em relação à campanha foram positivos: 

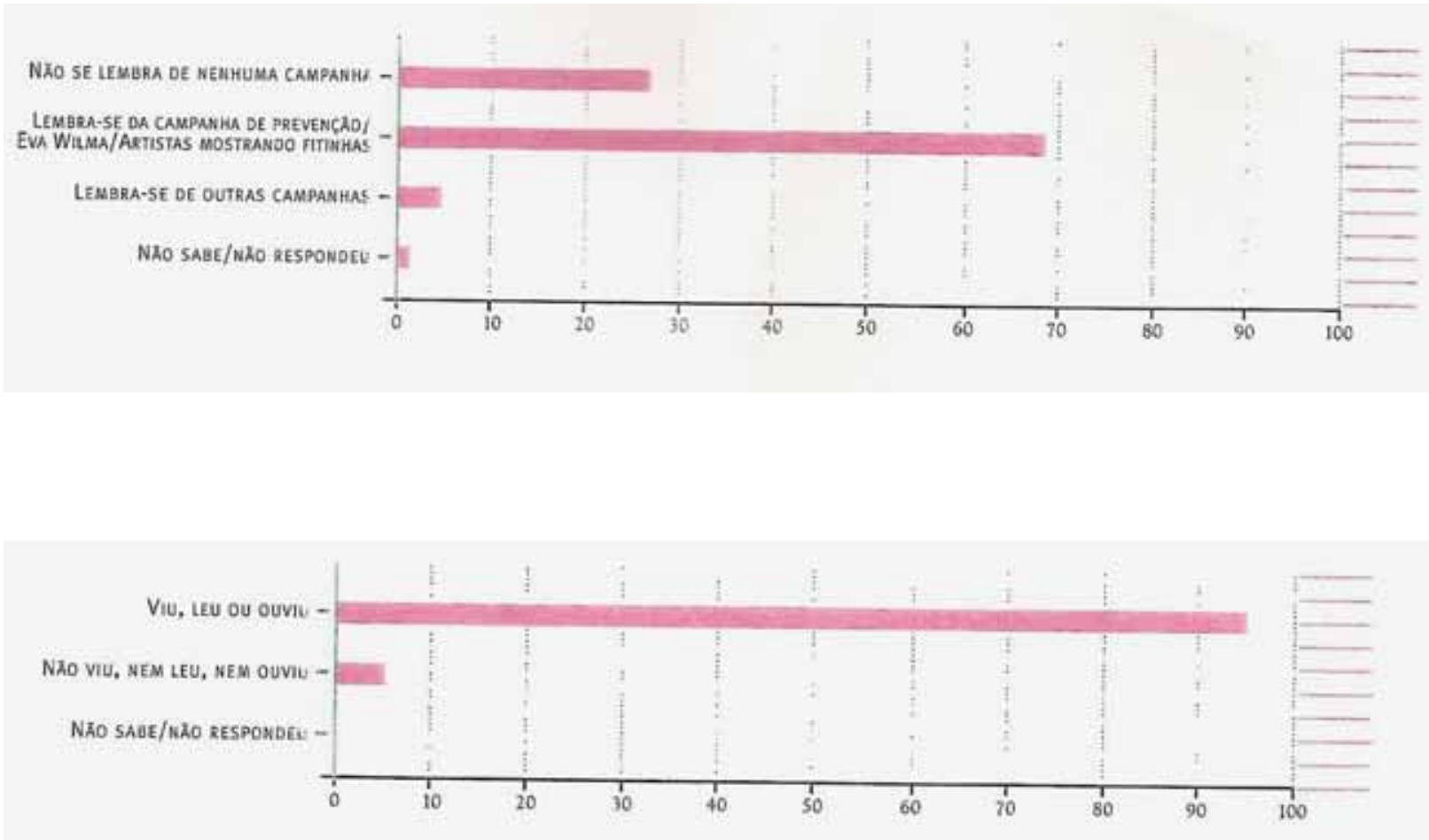

Gráficos 9 e 10 - Recall da campanha O Câncer de Mama no Alvo da Moda - Fonte: Inca/MCI

Índice de meios de comunicação com maior poder de assimilação sobre a campanha avaliada:

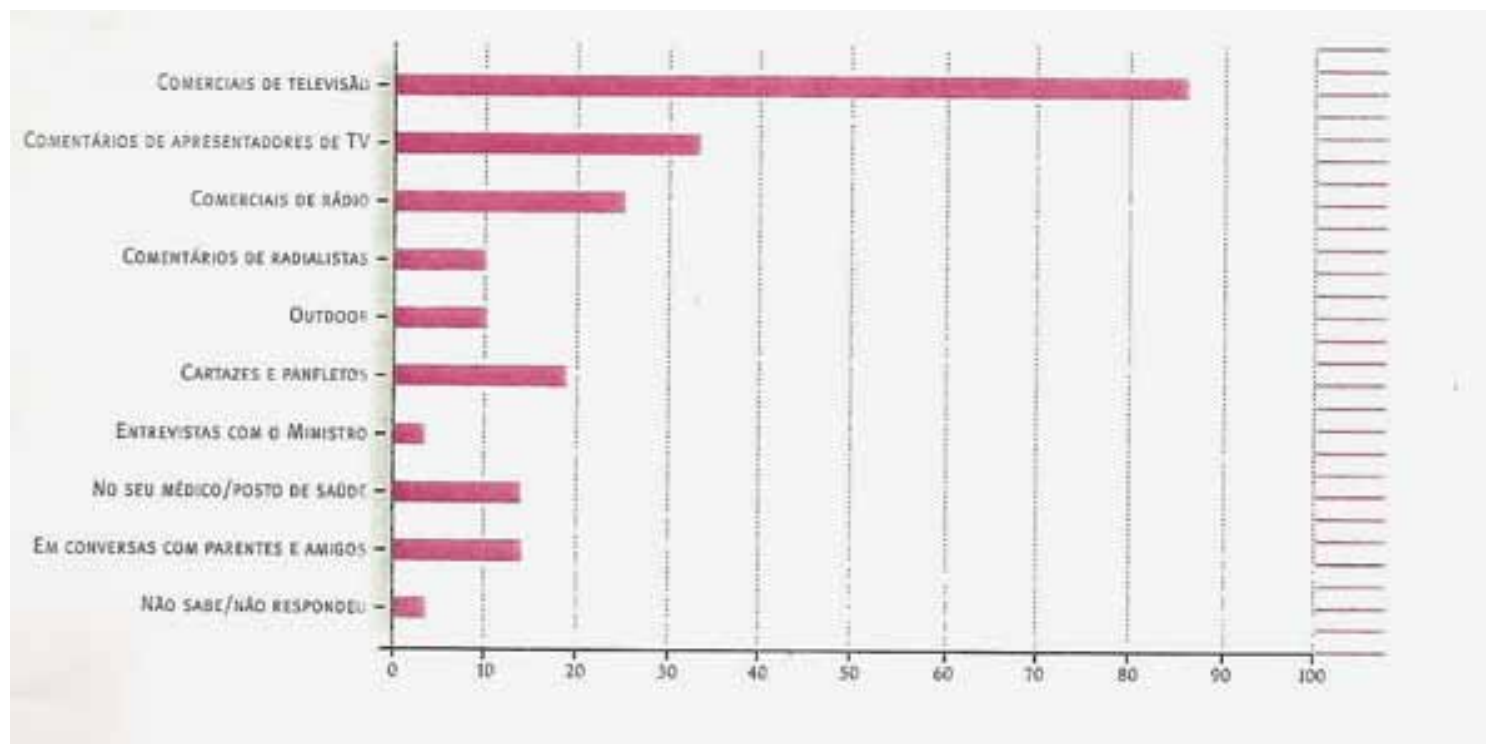

Gráfico 11 - Veículos mais lembrados da campanha O Câncer de Mama no Alvo da Moda -

Fonte: Inca/MCI 
Índice de avaliação geral das entrevistadas sobre a campanha:

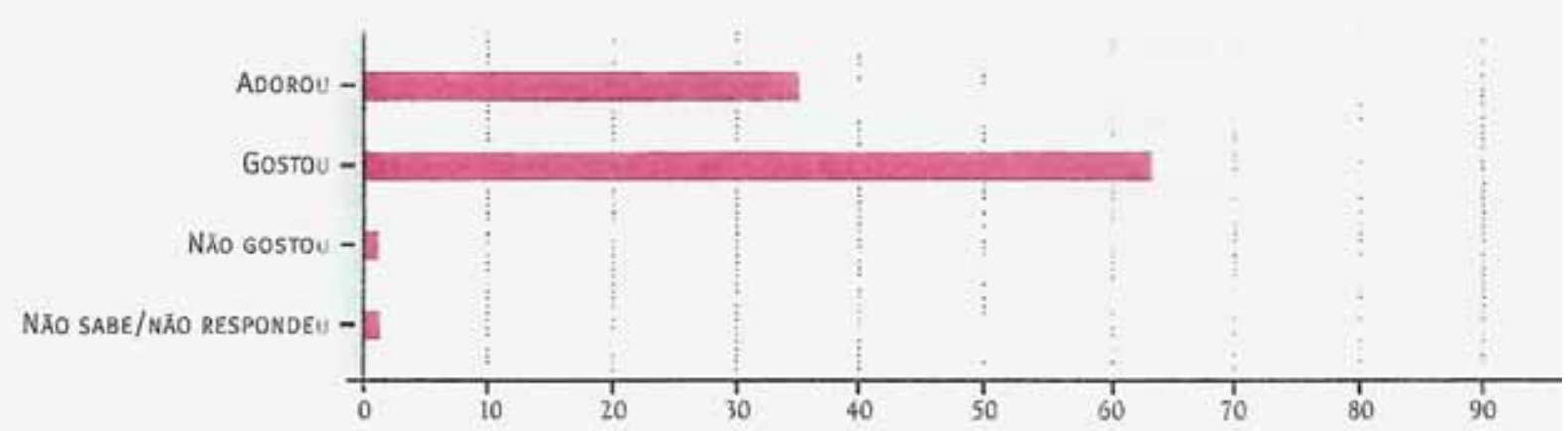

Gráfico 12 - Avaliação geral das entrevistadas sobre a campanha O Câncer de Mama no Alvo da Moda - Fonte: Inca/MCI

O resultado foi satisfatório e o apoio da comunicação, principalmente as propagandas televisivas foram fundamentais para o reconhecimento da campanha por conta do públicoalvo. E apesar do alcance ter sido para todas as mulheres, segundo o Inca, “A principal fonte de informações das mulheres ocorreu por meio do contato com o profissional de saúde (70\%).” Isso porque os panfletos eram basicamente destinados aos postos de saúde, ou seja, a campanha atendeu basicamente às mulheres que já procuravam ou estavam em contato com os profissionais da área médica.

- Resultados de avaliação quantitativa da Fase de Intensificação do Programa Viva Mulher:

- Período: 18 de agosto a 30 de setembro de 1998

- Localidades: todos os Estados do Brasil

- Faixa etária prioritária: 35 a 49 anos

· Número de exames citopatológicos: 3.177 .740

- Número de exames citopatológicos cadastrados no Sistema de Informação do Câncer do

Colo do Útero - SISCOLO: 2.150 .751

- Percentual de amostras insatisfatórias: 3,4\% 
- Percentual de mulheres que realizaram o exame pela primeira vez na vida: $28,6 \%$

- Mulheres com exames sem alterações: 2.090 .089

· Mulheres com algum tipo de alteração: 60.662

Outros pontos a serem ressaltados em uma campanha nacional e que devem servir de base para próximas etapas foram: primeiro, a união de todos os profissionais do Brasil em redes assistenciais de saúde feminina; segundo, a influência da troca de governos e gestores de órgãos públicos na realização prática dos exames e na geração de dados sobre o câncer de colo de útero.

\begin{abstract}
Um ponto positivo para o estabelecimento de uma rede geopolítica no País foi a realização de convênios entre o Ministério da Saúde e as Secretarias Estaduais de Saúde, oferecendo recursos não assegurados no estado, para a consolidação do programa. Este convênio, apesar de já ter possibilitado a capacitação de recursos humanos em alguns estados, teve limitações em sua utilização, pela troca de gestores estaduais, de coordenadores do programa, pelo período eleitoral e pela própria burocracia, que impediu sua utilização. (INCA, p.94)
\end{abstract}

Mesmo com ganhos e avanços da campanha nacional sobre câncer de colo de útero, não existia ainda nada similar de âmbito governamental sobre o câncer de mama. As ações para tal doença se encontravam sob a ótica das manifestações pontuais de promoção de saúde pública. Contudo, anos mais tarde, a doença foi incorporada às ações comunicativas do Ministério da Saúde e do Inca quando divulgaram a adaptação do projeto para: Viva Mulher Programa Nacional de Controle do Câncer do Colo de Útero e de Mama. 


\section{4 - Incorporação do Câncer de Mama no Programa Viva Mulher}

Há apenas algumas décadas atrás, o câncer de colo de útero matava mais mulheres do que o de mama. Atualmente, deve-se considerar um quadro nacional reverso, com taxas em estabilidade para o primeiro e ascendentes para o segundo.

$\mathrm{Na}$ análise dos materiais realizados pelo Inca a partir do início do século XXI, podem-se notar duas linhas de comunicação distintas publicadas somente como folhetos de divulgação em postos de saúde.

As Figuras 30 a 35 fazem referência à primeira abordagem; apesar da inclusão do assunto câncer de mama, o desenho escolhido para representar a feminilidade foi uma pêra, em alusão ao órgão genital feminino. $\mathrm{Na}$ capa, a fruta se encontra em boa qualidade e com aspecto saudável; já na contracapa, a mensagem torna-se mais impactante quando a mesma aparece deteriorada e passada. Ou seja, as fases da pêra representam a aquisição do câncer de colo de útero no corpo da mulher. Nessa linha criativa, não existem representações para o câncer de mama ou para o seio feminino.

Apesar desses folhetos terem sido distribuídos apenas para os profissionais de saúde, e os dizeres não informarem sobre prevenção, e sim, sobre o que é o Programa Viva Mulher, a metáfora da fruta podre não aparenta ser a melhor escolha para retratar uma enfermidade feminina. A pêra já estragada nunca mais voltará a estar em condições normais; pensando em representar uma mulher com necessidade de tratamento, este não é o caminho mais otimista.

As cores adotadas são o amarelo, que possui uma forte capacidade para despertar a atenção do leitor e obter impulsos de adesão, e o marrom, que, embora reflita uma sensação cromática sombria, é caracteristicamente vinculado à fertilidade e à mestiçagem da população brasileira. Segundo Farina, Perez e Bastos (2006, p.104): “Ao marrom se associa a cor da pele morena, as cabrochas. Na antiguidade a cor morena era feminina, por ser a cor da terra e, portanto a fecundidade." 

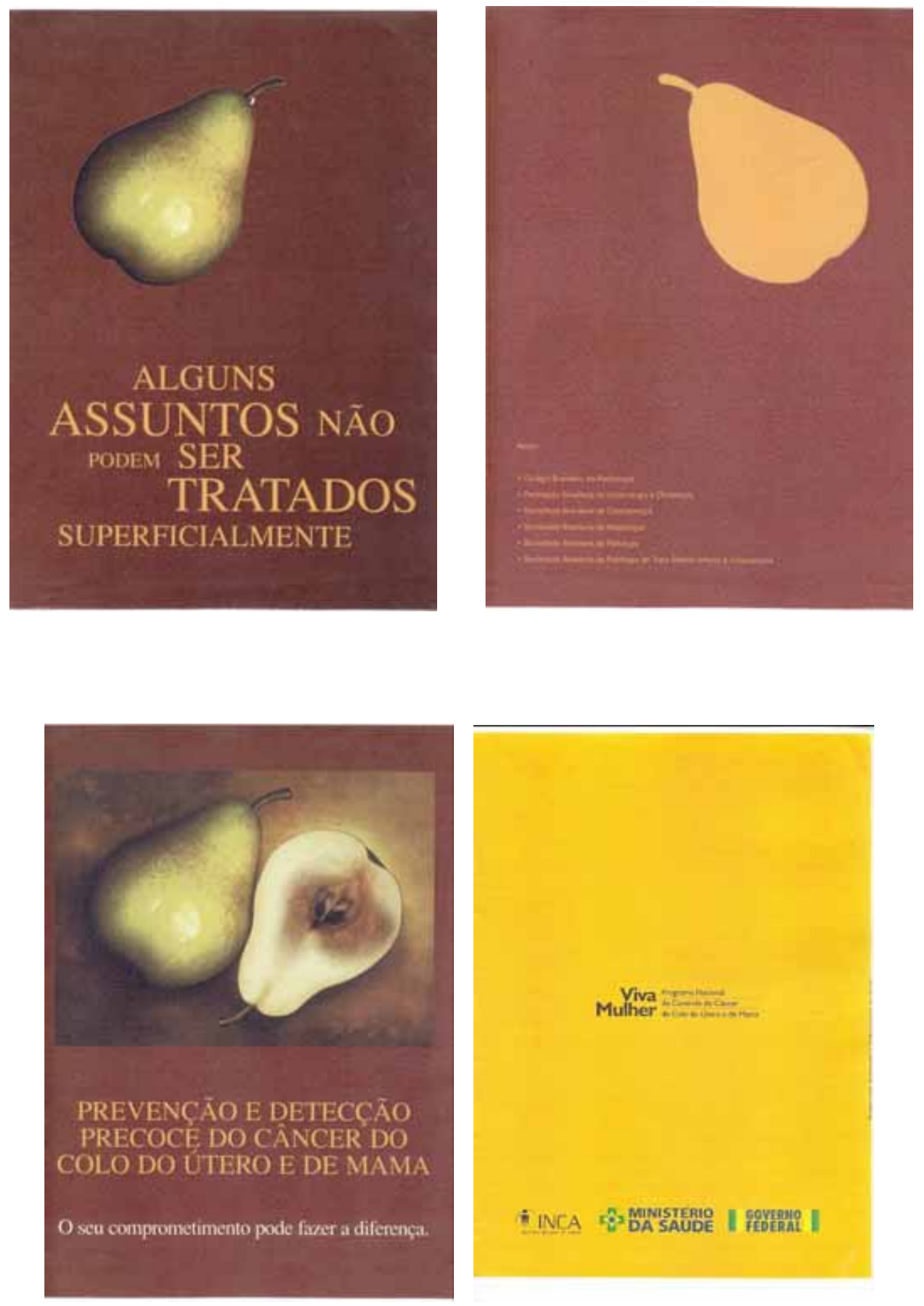

Figuras 41, 42, 43 e 44 - Frente, verso, contracapa e $3^{\text {a }}$ capa de folheto da campanha do Programa Viva Mulher já com a inclusão do Câncer de Mama 


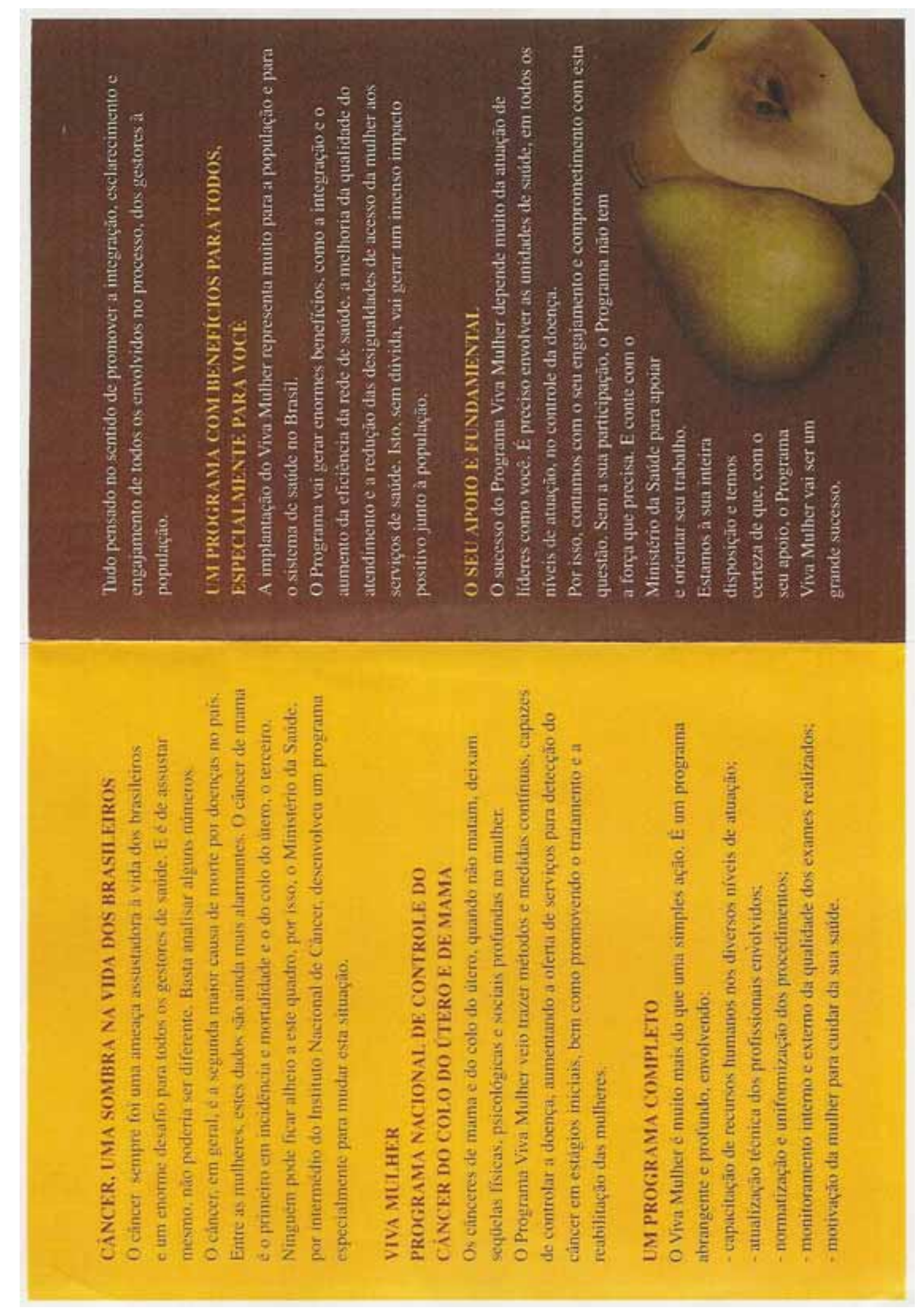

Figura 45 - Interior de folheto da campanha do Programa Viva Mulher já com a inclusão do Câncer de Mama 

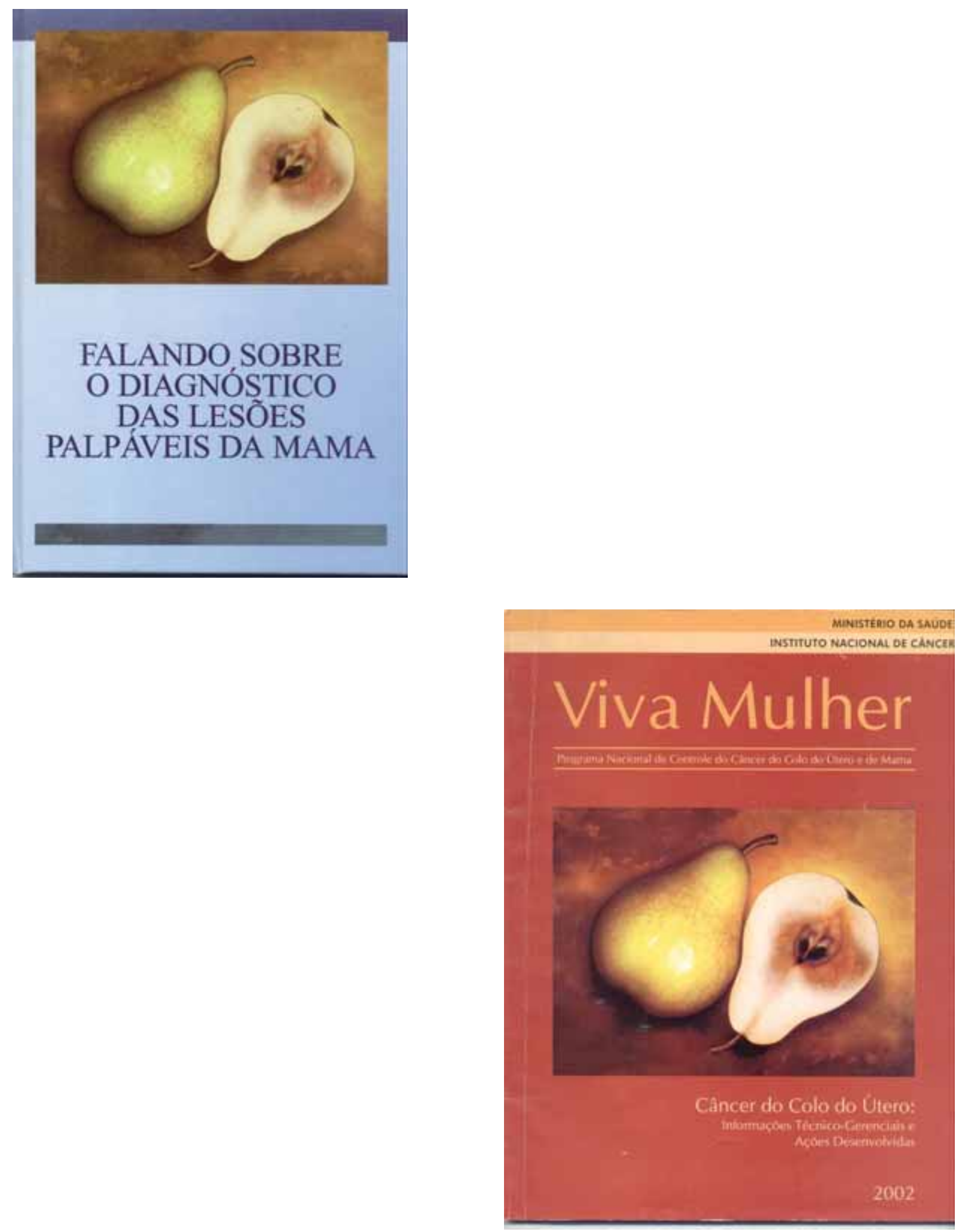

Figuras 46 e 47 - Capa dos materiais técnicos desenvolvidos pelo Programa Viva Mulher distribuídos a profissionais dos postos de saúde 
A partir do ano de 2003, os folhetos produzidos pelo Inca mudaram bastante suas características visuais. Embora ainda pertencente ao Programa Viva Mulher, o câncer de mama passou a ter sua comunicação exclusiva, deixando de estar sempre agregado às peças de câncer de colo de útero, o que já era esperado, já que infelizmente seus dados de mortalidade passaram a ser os mais altos nos últimos anos. Ao contrário, hoje, no Brasil, o câncer de colo de útero já apresenta um dos mais altos potenciais de prevenção e cura, chegando perto de $100 \%$ quando diagnosticado precocemente. ${ }^{53}$

Mesmo sem uma campanha nacional intensa, a publicidade dos folhetos do Inca tornou-se mais uniforme e informativa quando se iniciou a segunda abordagem da inclusão do câncer de mama nos folhetos, com explicações mais detalhadas sobre a doença, como por exemplo, quem são as mulheres de alto risco, como são realizados os exames, quais são os tratamentos, como é feita a cirurgia e até o papel da sociedade civil organizada. Uma característica importante nesse novo material é o fato de que o auto-exame das mamas é citado, todavia destaca-se que a prática não substitui o exame físico realizado pelo profissional de saúde.

O folheto e o Consenso para o Controle do Câncer de Mama, expostos nas Figuras 36 a 42, são os mais recentes e vigentes materiais realizados pelo Inca. Nota-se que em termos de comunicação, ainda poderiam ser usadas diversas ferramentas, como foi feito em 1998 com a fase de intensificação da campanha, como a utilização de rádio, TV, outdoors, entre outros.

Atualmente no Brasil, o principal documento que explicita a proposta do Programa Nacional de Controle do Câncer de Mama, no qual o rastreamento é uma das principais estratégias, é o Consenso de Controle do Câncer de Mama. Cabe ressaltar que esses mesmos materiais melhor detalhados, nos quais há o acréscimo de informações técnicas e eventuais dúvidas, encontram-se também no site da instituição.

O padrão estabelecido nesses materiais é composto por apenas um desenho sutil de um corpo feminino jovem, muitas vezes utilizado em forma de marca d'água ${ }^{54}$, nas cores rosa claro e vinho, e com muitos textos explicativos. O símbolo do Inca já não aparece mais; apenas é citado o endereço eletrônico, o telefone do Disque Saúde e uma referência ao Ministério da Saúde.

A mulher simulada já quase não aparece, não está mais representada em fotografia ou em bonecos. Em comparação ao primeiro material publicado, Folheto número 2 (páginas 104

\footnotetext{
${ }^{53} \mathrm{http} / / /$ www.inca.gov.br/conteudo_view.asp?id=140

${ }^{54}$ Ferramenta para desenhos computadorizados, nos quais os traços tornam-se tão suaves que é possível mesclá-los com textos.
} 
e 105), as mudanças textuais foram significativas, com o acréscimo de dados e explicações sobre a doença. A escolha do título Consenso remete às palavras harmonia e bom-senso, o que também transmite uma opção significativamente mais suave na criação das peças.
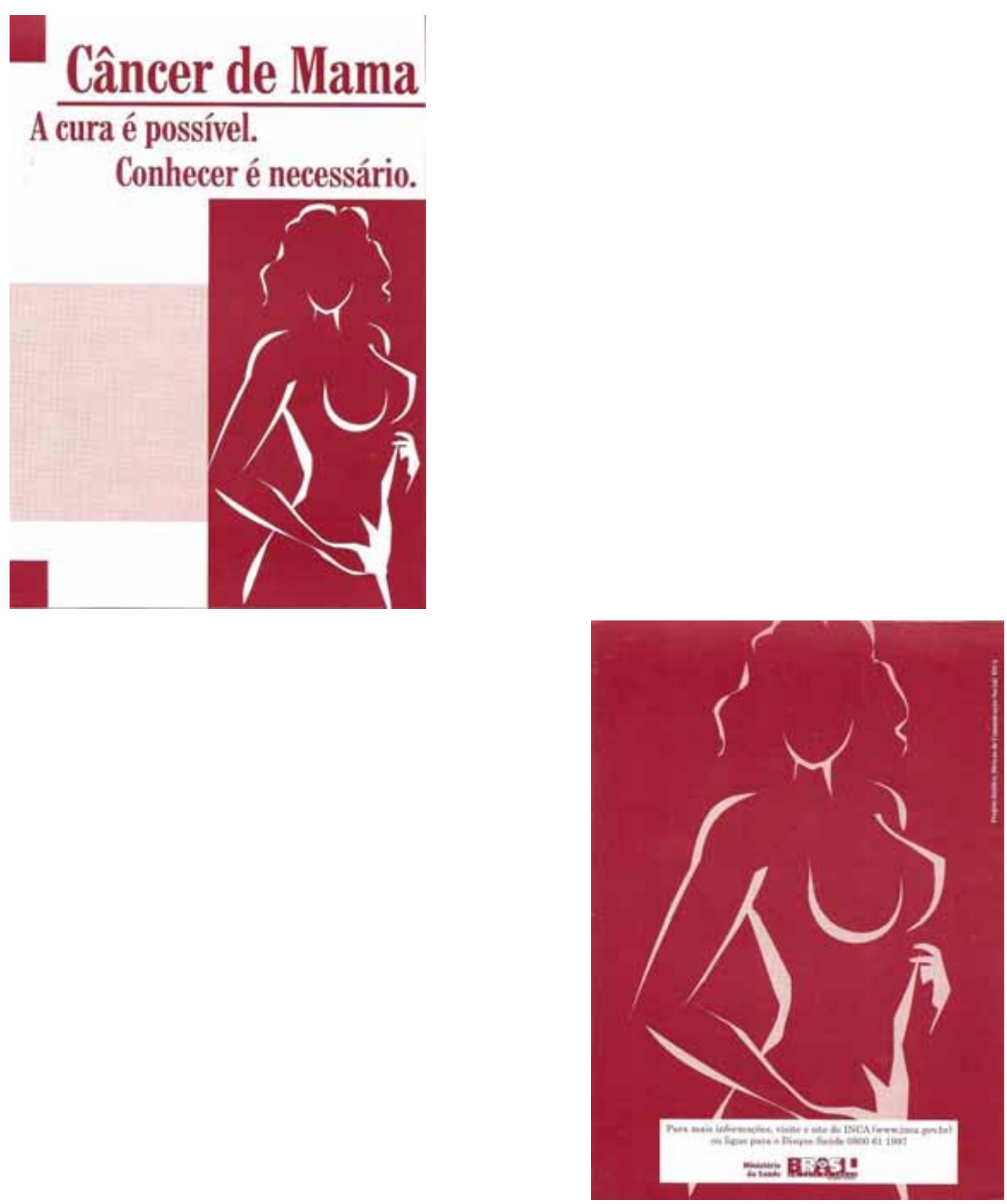

Figuras 48 e 49 - Frente e verso do último folheto produzido pela campanha do Programa Viva Mulher, no qual o câncer de mama já é retratado especificamente 

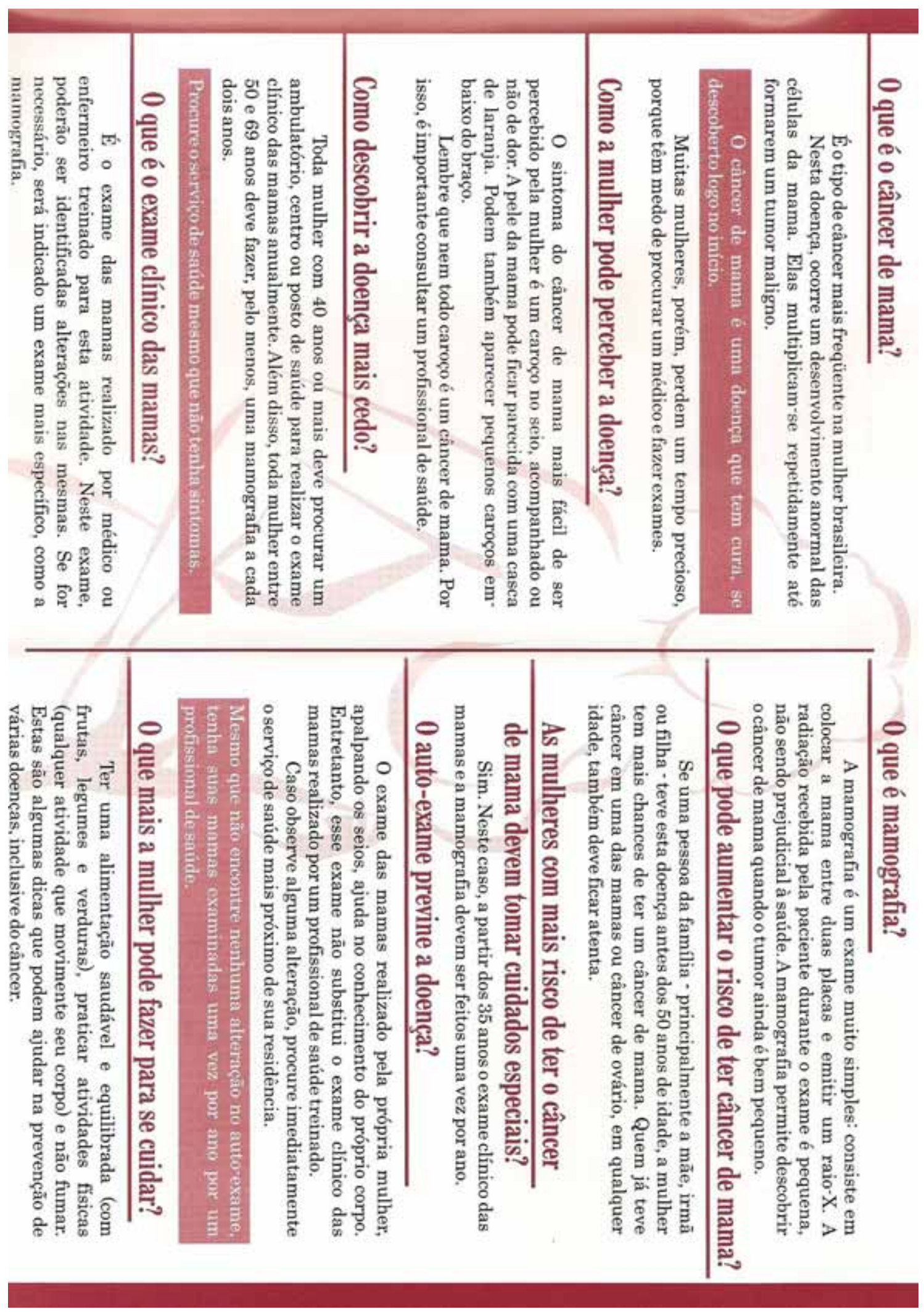

Figura 50 - Interior do último folheto produzido pela campanha do Programa Viva Mulher, no qual o câncer de mama já é retratado especificamente 


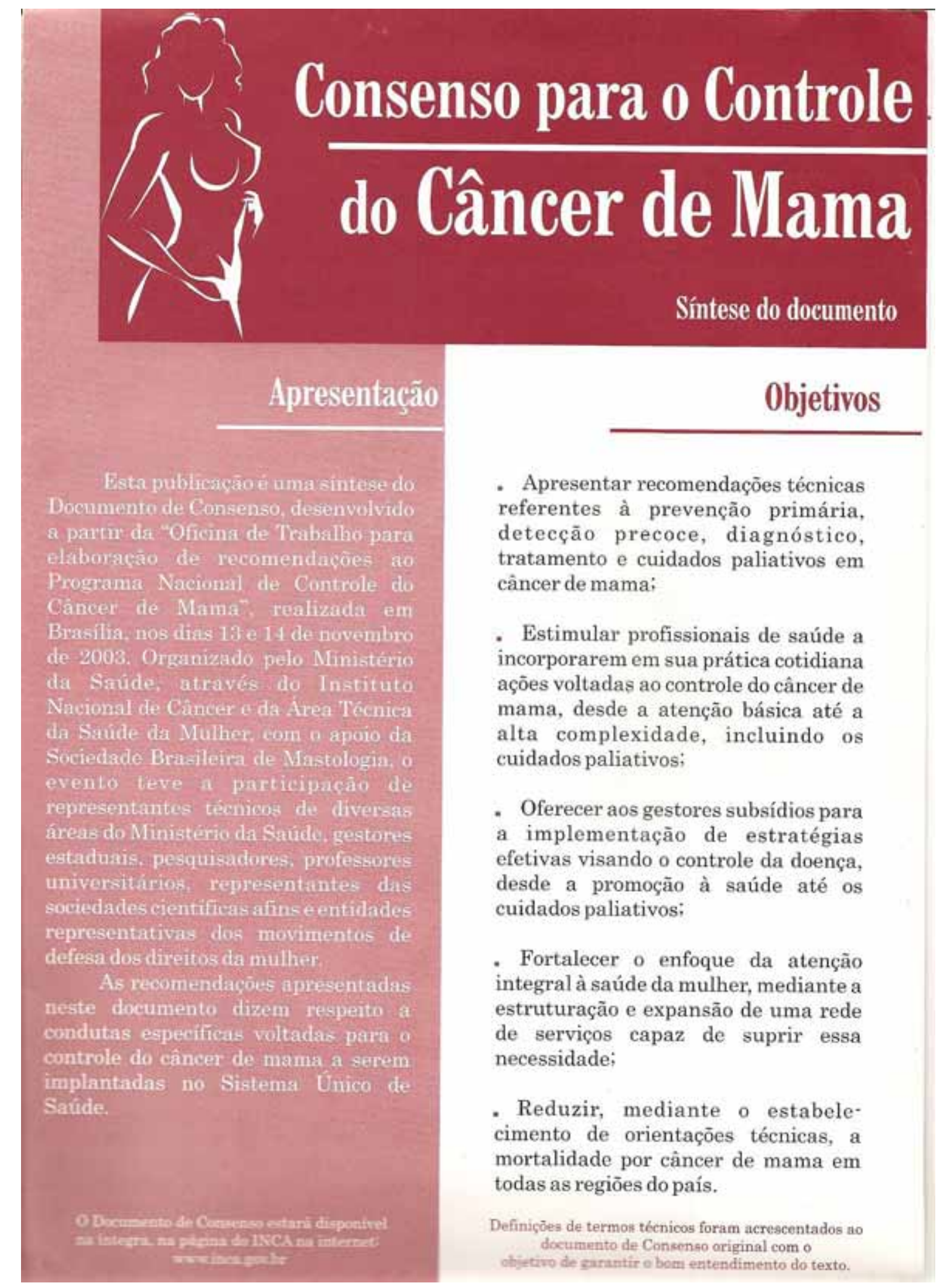

Figura 51 - Frente do Consenso para o Câncer de Mama, principal material que explicita a proposta do programa nacional de controle da doença 


\section{Prevenção Primária}

Embora tenham sido identificados alguns fatores ambientais ou comportamentais associados ao risco de câncer de mama, os estudos epidemiológicos não fornecem evidência conclusiva que justifique estratégias específicas de prevenção primária.

Açōes de promoção à saúde dirigidas ao controle das doenças crônicas não transmissiveis (o que inclui o câncer de mama) devem focar os fatores de risco, especialmente a obesidade e o tabagismo.

\section{Mulheres de alto-risco}

São consideradas mulheres de risco elevado aquelas com:

- um ou mais parentes de primeiro grau (mãe, irmã ou filha) com câncer de mama antes de 50 anos:

- um ou mais parentes de primeiro grau (mãe, irmã ou filha) com câncer de mama bilateral ou câncer de ovário;

- história familiar de cancer de mama masculina;

- lesão mamária proliferativa com atipia comprovada em biópsia.

Não há consenso na comunidade científica internacional de que a quimioprofilaxia seja recomendada a mulheres assintomáticas, mesmo aquelas com maior risco.

Definc se quimieprofilavia como o uso de um agente quimioterípico vifando is prevenciro do desenvolvimento de umadoença.
Definterse rastreamento coino o exame felito eta pessepas aspintomiticas objetivando identificar squelas que posfatm apresentar a drença em fast muito inicial, quando a intertenchào precoce pode tur grande beneficib. Umi teste de pastreamente nio tem por fim fiser diagnostico definitivo, man inclicar pessoas que por apresentinem exames

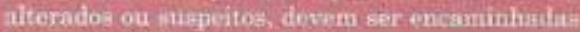
parin investigacan diaghosties.

\section{1- Exame Clínico das Mamas}

- O exame clínico das mamas deve fazer parte do atendimento integral à mulher em todas as faixas etárias;

- Para mulheres com 40 anos ou mais o exame clínico das mamas deve ser realizado anualmente.

\section{2-Mamografia}

\section{Mulheres entre 50 e 69 anos de idade}

- Mulheres na faixa etária entre 50 e 69 anos de idade devem ser submetidas a rastreamento mamográfico pelo menos a cada dois anos:

- As mulheres submetidas ao rastreamento devem ter garantido o acesso aos exames de diagnóstico, ao tratamento e ao seguimento das alteraçōes encontradas.

\section{3-Mulheres com risco}

elevado para 0 câncer de mama

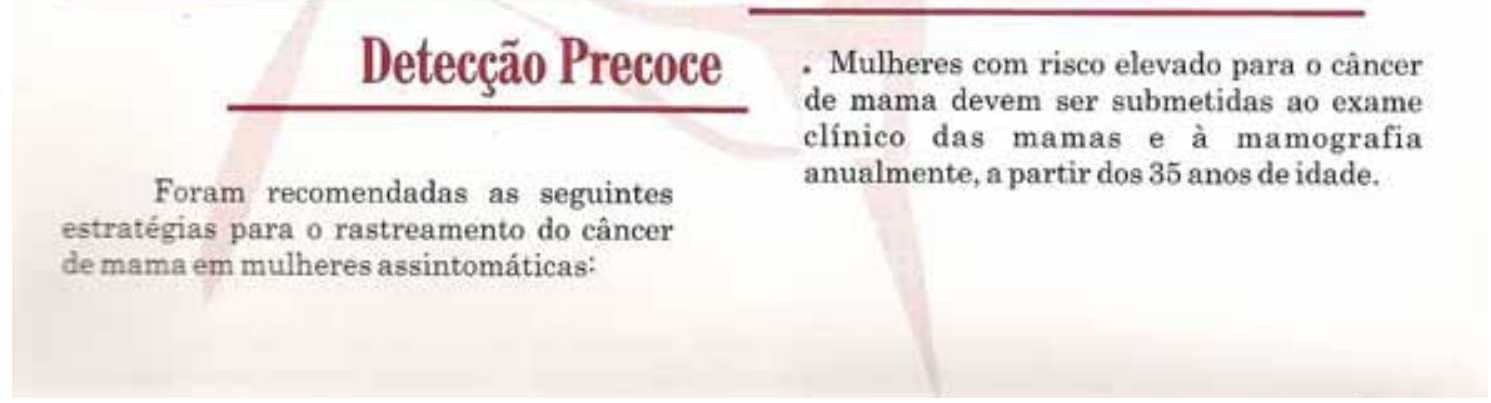

Figura 52 - Frente do Consenso para o Câncer de Mama, principal material que explicita a proposta do programa nacional de controle da doença 


\section{Recomendações para 0 auto-exame}

- Devem ser desenvolvidas ações de educação para a saúde que contemplem o conhecimento do corpo, incluindo o exame das mamas realizado periodicamente pela própria mulher (auto-exame);

- Deve'se destacar que o exame das mamas realizado pela própria mulher não substitui o exame físico realizado por profissional de saúde treinado para esta atividade.

\section{Diagnóstico}

- O exame clínico da mama constitui a base para a solicitação dos exames complementares:

- O exame histopatológico fornece os elementos necessários para o adequado manuseio clínico da paciente sob o ponto de vista prognóstico e terapêutico;

- Devem ser descritas as características da neoplasia (tamanho do tumor, tipo histológico segundo classificação da OMS, 2003), grau histológico (Nottinghan), grau de invasão vascular, estado linfonodal e comprometimento das margens cirúrgicas. Além disso, recomenda-se a realização de receptores de estrógenos e progesterona (imunohistoquímica) e o estadiamento do caso conforme a classificação TNM da UICC (2003).

\section{Tratamento}

- $O$ cancer de mama deve ser abordado por uma equipe multidisciplinar visando ao tratamento integral da paciente.

- As modalidades terapéuticas disponíveis atualmente são a cirurgia e a radioterapia para o tratamento loco-regional e a hormonioterapia e a quimioterapia para o tratamento sistêmico.

\section{Cirurgia}

A indicação dos diferentes tipos de cirurgia depende do estadiamento clínico e do tipo histológico, podendo ser conservadora (ressecção de um segmento da mama com retirada dos gânglios axilares ou linfonodo sentinela) ou não conservadora (mastectomia).

São prérequisitos para se indicar a cirurgia conservadora:

- Mamografia prévia:

- Diâmetro tumoral inferior a $3 \mathrm{~cm}$, levando em consideração a proporção do tumore da mama e a localização;

- Auséncia de comprometimento da pele:

- Tumor único;

- Margens cirúrgicas livres;

- Facilidade de acesso ao sistema de saúde para o seguimento.

No carcinoma ductal in situ recomenda-se: - Segmentectomia seguida de radioterapia para os tumores menores que $2 \mathrm{~cm}$ e margens cirúrgicas livres:

- Mastectomia simples para tumores onde não é possivel a obtenção de margens cirúrgicas livres pela sua extensão ou multicentricidade;

- Mastectomia simples com linfoadenectomia de nível 1 ou dissecçâo do linfonodo sentinela nos casos de comedonecrose ou alto grau histológico.

Nos carcinomas invasores com:

- Diâmetro menor que $3 \mathrm{~cm}$ recomenda-se a cirurgia conservadora com linfoadenectomia axilar completa e avaliação das margens cirúrgicas. Quando a margem cirúrgica se mostrar comprometida está recomendada a re* excisão. Nos casos de axila clinicamente não comprometida pode ser indicada a linfoadenectomia seletiva pela técnica do linfonodo sentinela, quando disponivel.

- Diâmetro igual ou maior que $3 \mathrm{~cm}$, com ou sem quimioterapia neoadjuvante recomenda-se a mastectomia radical modificada.

Na neoplasia lobular in situ, que é considerada um fator de risco para o desenvolvimento de carcinoma, indica-se a biópsia excisional (diagnóstica e terapêutica). Esta condição exige vigilância especial com a realização de exame clínico semestral e mamografia anual.

Figura 53 - Interior do Consenso para o Câncer de Mama, principal material que explicita a proposta do programa nacional de controle da doença 


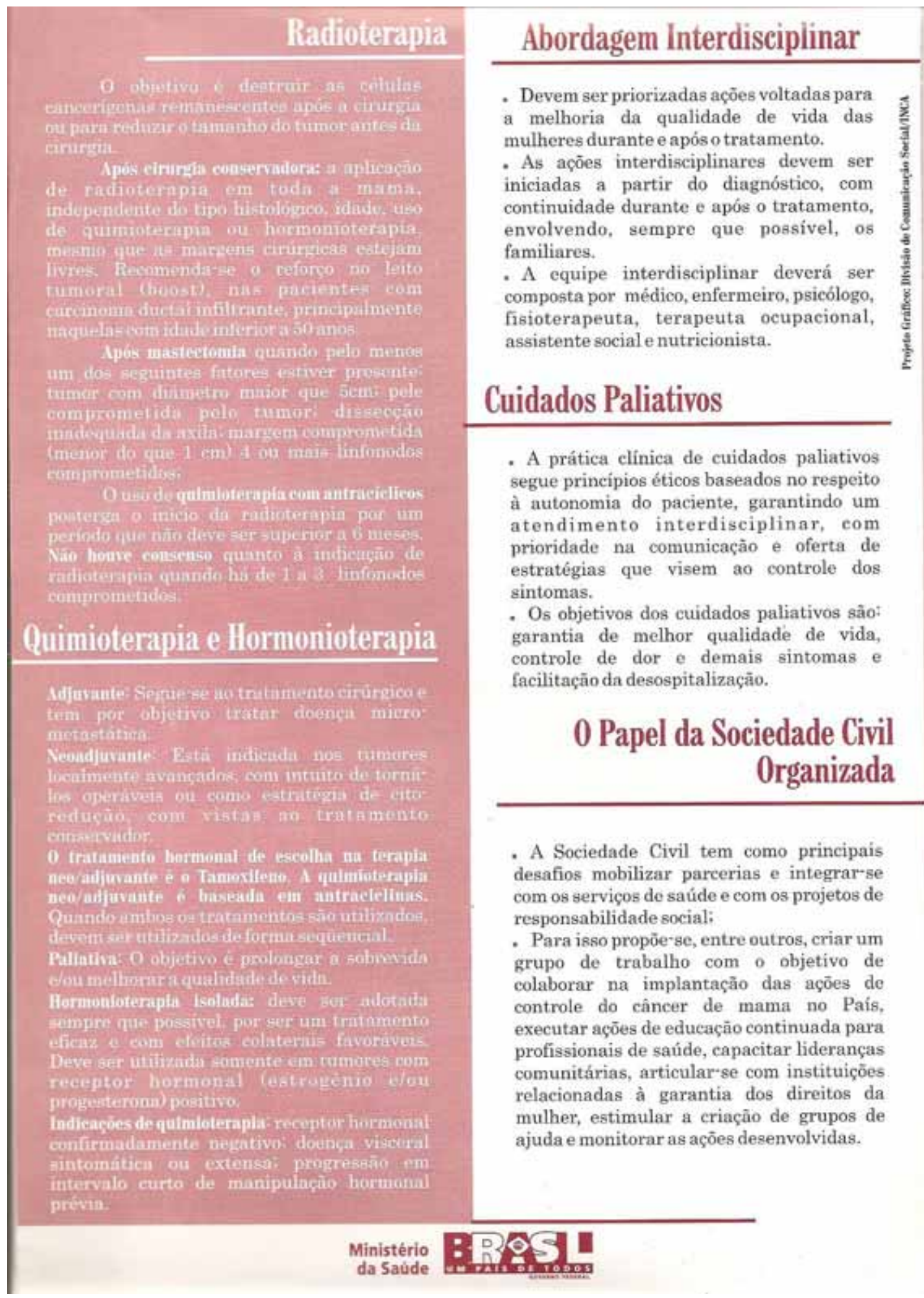

Figura 54 - Verso do Consenso para o Câncer de Mama, principal material que explicita a proposta do programa nacional de controle da doença

A totalidade dos materiais de divulgação recolhidos, expostos e comentados nesta última etapa, já com a inclusão do câncer de mama no Programa Viva Mulher, é destinada aos 
profissionais de saúde, os quais se responsabilizam pela circulação das informações sobre a doença. Tais agentes locais, apesar de assumirem posições de propagandistas e educadores de plantão, não conseguem expor o assunto a todas as mulheres; infelizmente, atingem apenas aquelas que já procuraram algum posto médico.

A ausência do apoio de divulgação massiva, com a utilização de outras mídias e veículos de comunicação, torna-se algo indagador na medida em que as chances de cura para a doença são transferidas para as ações individuais da mulher, quando esta já se encontra na procura de subsídios e conhecimento sobre o assunto na ocasião de algum sinal ou apenas por curiosidade pelo tema câncer de mama. Assim sendo, a prevenção como meta para erradicação do câncer de mama deixa de ser trabalhada.

As manifestações de publicidade informativa por parte de empresas e organizações da sociedade civil encontram-se tão arraigadas às práticas nacionais que até no último folheto público realizado, o Consenso para o Câncer de Mama, encontra-se algo a respeito e explicações. Não está errada tal menção; porém, o viés da saúde pública feminina acabou por ser transferido, e infelizmente não existem ainda grandes ações por parte do Estado com a finalidade de orientar a atenção das mulheres sobre a doença.

As ações não precisariam ser necessariamente em forma de grandes campanhas ${ }^{55}$ publicitárias, mas deveriam ser constantes e em diferentes meios de comunicação, com grandes alcances para que a prevenção do câncer de mama não fosse lembrada esporadicamente, e sim, realizada rotineiramente.

A única campanha massivamente divulgada abordava a mulher a partir de uma perspectiva de memorização. Na fase de intensificação da campanha em 1998, os materiais de divulgação adotaram o slogan "Lembre alguém”, com a utilização da fita cor-de-rosa, e se apoiaram na figura de uma mulher como uma médica, segura, para assim presumir uma ação efetiva da população. Porém, a lembrança é algo oposto ao conhecimento; em outras palavras, o que é transposto ao saber humano e se torna uma prática, seja pedagógica ou mecanicamente preventiva, não precisa ser recordado, pois já está pré-concebido na ação.

Toda e qualquer manifestação nos veículos de comunicação referente à saúde, e conseqüentemente ao câncer de mama, poderia não ocorrer apenas na decorrência da eventualidade, mas na perspectiva de transformar os elos de diálogo público em apoios

\footnotetext{
55 Apesar de constantes buscas em agências publicitárias, não houve retorno de nenhuma; isso devido a uma falta de arquivo sobre a campanha e às constantes trocas de gerenciamento da conta do Ministério da Saúde. Porém, devido ao material concedido pelo Inca, foi possível analisar alguns os veículos de comunicação utilizados: rádio, cartazes, outdoor, folhetos, televisão, etc.
} 
educativos os quais aproximam Estado e sociedade. Soluções temporárias apenas modificam números, dados e gráficos; pouco depois, os índices de mortalidade voltam a subir. Um exemplo é o final da campanha de intensificação do Programa Viva Mulher, quando as taxas apresentadas de exames papanicolau no SUS voltaram a decrescer.

Produção ambulatorial do SUS

Quantidade apresentada de exames citopatológicos cérvico-vaginais e microflora

Código: 12.011.01 - Período: Julho/1994 a Junho/2001

Brasil

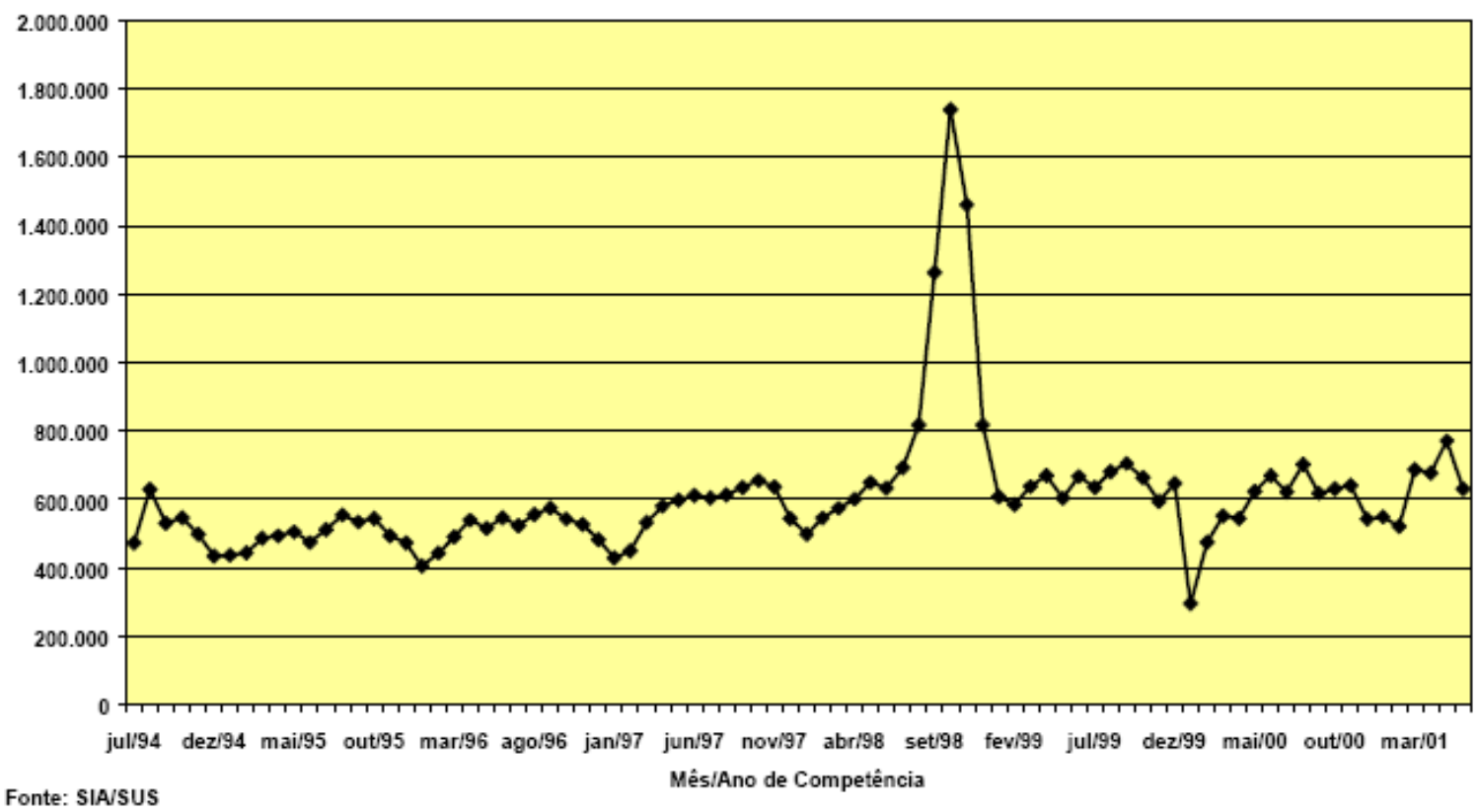

Gráfico 13 - Produção ambulatorial de exames de colo de útero no SUS de julho/1994 a março/2001

Fonte SIA/SUS 


\section{Considerações finais}

O aumento da incidência do câncer de mama no Brasil é explicado, em primeiro lugar, pela diminuição de óbitos por outras epidemias nacionais, e em segundo, pelo fato do diagnóstico ser mais preciso; hoje, a contabilização consegue demonstrar exatamente o número de casos.

Conforme aumenta a incidência, maiores são os trabalhos de pesquisa, prevenção, tratamento e gastos públicos com a doença. As ações de comunicação, por conseqüência, multiplicam-se igualmente em formato de peças publicitárias, matérias e anúncios que aparecem em destaque na mídia em geral.

Todavia, constata-se que para obter verdadeira eficácia nas propagandas desenvolvidas, a criação necessita no mínimo conter subsídios potenciais de apelo e entendimento por parte das mulheres.

$\mathrm{Na}$ pesquisa, por meio da análise semiótica, foram interpretados alguns dos significados possíveis das peças publicitárias dos dois institutos nacionais mais relevantes sobre câncer de mama, o Inca e o IBCC. Apontou-se os prováveis signos interpretantes gerados nas mulheres nas duas campanhas, mas certamente existem ainda muitas outras ferramentas para comprovar a eficácia das mensagens criadas.

Para uma maior compreensão do público-alvo dessas ações publicitárias seria necessária uma divulgação constante nos diversos meios de comunicação. No caso do Inca, a premissa não acontece, já que as peças não possuem poder de inserção na grande mídia. A única grande campanha nacional, realizada dentro do Programa Viva Mulher, abordou somente o câncer de colo uterino e apenas em determinados meses de divulgação.

O problema das grandes campanhas de comunicação é o fato de a imediatez do acontecimento não aprofundar o assunto, ou seja, elas não introduzem a prática do exame como característica efetiva e rotineira na vida da mulher. Sem dúvida, como comentado no capítulo IV, item Propagandas de Apoio, sobre o acordo da Confederação Nacional da Indústria - CNI e a Federação das Indústrias do Estado de São Paulo - Fiesp sobre a liberação de suas operárias mais cedo em um dia de serviço para a realização dos exames é uma conquista. Mas o fato é que essas iniciativas são pontuais; ainda existe a necessidade de retorno da trabalhadora ao posto de saúde para a busca de resultados ou, no caso do exame diagnosticar algum sintoma positivo, direcionar-se ao tratamento. Os acompanhamentos nas fases da pós-campanha não estão dentro do contexto das campanhas esporádicas, não 
excluindo assim o dever do Estado de criação e manutenção constante das políticas de saúde pública femininas.

A campanha do IBCC, O Câncer de Mama no Alvo da Moda, em termos de utilização e inserção midiática, é muito mais dinâmica e abrangente. Além de constar fixamente no vestuário brasileiro, a marca da campanha, com seu símbolo em forma de um alvo azul, aparece estampada em revistas, outdoors, rádio, TV, entre outros veículos. Todavia, a mensagem original se perde entre a adesão da classe artística, invertendo parte de sua linguagem em mais um adereço de figurino e, como a própria palavra moda designa, algo frívolo.

Agregar o câncer de mama à fluidez efêmera de uma campanha de moda não é de todo mau quando se pensa nas proporções culturais e psicológicas que um fenômeno marcário pode surtir na natureza de nossa sociedade, sem contar as possibilidades financeiras que tal publicidade gera ao IBCC e às suas pacientes atendidas. Apenas faz-se relevante pensar na linguagem estabelecida, pois com uma comunicação mais estruturada, as peças analisadas poderiam, além de acarretar lucro, motivar a prevenção e a absorção da informação sobre a doença.

O slogan divulgado pela campanha do Inca "lembre alguém", mais a adoção da fita cor-de-rosa são estratégias que recorrem ao aspecto do esquecimento. Algo necessário, mas momentâneo, que após certo tempo terá novamente que ser lembrado. Já o mote do IBCC é $O$ Câncer de Mama no Alvo da Moda. Não traz a mínima realidade com o panorama da doença e se distancia da mulher em si.

A linha criativa de ambas instituições não trouxe o aspecto mais positivo que existe em detectar um câncer de mama a tempo, isto é, a vida. Nenhuma das opções adotadas realçou o fato de que se as mulheres prestarem atenção aos anúncios realizados e às técnicas preventivas, o valor de troca não será a lembrança do Inca ou a moda do IBCC, mas sim, a própria condição de existência diante do risco da doença mais freqüente nas mulheres brasileiras, e a sua reintegração social, por conseqüência.

No caso do Inca, a falta de uma difusão alinhada e contínua de publicidade deve-se, entre outros motivos, à intercessão da área política no campo da comunicação. Conforme demonstrado no histórico das atividades do instituto, além da transferência temporária de suas atividades do Ministério da Saúde para o Ministério da Educação, observou-se uma profunda mudança na linha criativa dos materiais do Inca nos anos eleitorais.

Em 1998, com a fase de intensificação e implantação da campanha nacional Viva Mulher, ocorreu a troca de mandato de Carlos Cesar de Albuquerque para José Serra como 
Ministro da Saúde. Em 2003, com a troca do ministério de Barjas Negri para Humberto Sérgio Costa Lima, houve a opção de trabalhar o câncer de mama isoladamente, sem vinculálo mais à publicidade sobre colo de útero.

A aquisição do material para análise foi um dos pontos de maior dificuldade no desenvolvimento da pesquisa. Não foi possível obter a totalidade por falta de arquivo, tanto do Inca como das agências de publicidade responsáveis, pois estas, por sua vez, eram trocadas constantemente e não deixaram histórico de seus trabalhos, e a única fonte contatada não possuía em seu portfólio tais materiais.

Porém, graças ao apoio do setor de comunicação e da Coordenação de Ensino e Divulgação Científica do Instituto, foi possível o acesso às peças então analisadas, a montagem da cronologia de tais publicações e algumas visitas à sede do Inca, localizado na cidade do Rio de Janeiro.

O material de análise do IBCC também não foi fornecido por agências ou empresas vinculadas ao instituto, mas devido à abrangência da marca da campanha, o acesso aconteceu com mais facilidade via Internet, revistas e a colaboração dos funcionários da ECA-USP em solicitar à empresa Arquivo da Propaganda. ${ }^{56}$

Felizmente, as dificuldades encontradas não foram fatores de mudança para o conteúdo da pesquisa, pois a análise aconteceu por meio da relação do material recebido, que, somado ao respaldo das correntes teóricas, viabilizou a concretização deste trabalho, sendo possível alcançar um entendimento da comunicação realizada sobre câncer de mama nos dois principais institutos nacionais relacionados à temática.

O desenvolvimento da pesquisa demonstrou o quanto seria significativo um próximo estudo sobre gênero e comunicação abrangendo a análise para as políticas públicas femininas dentro de um paradigma global, no qual pela investigação dos meios fosse possível diagnosticar um retrato da imagem feminina nos programas sociais do Estado.

Será também interessante divulgar a pesquisa realizada em centros de apoios, instituições médicas e empresas que trabalham ou se interessam pelo assunto câncer de mama. O auxílio poderá acontecer com a finalidade de orientar o processo criativo para as campanhas de comunicação já criadas ou para nortear futuras estratégias de difusão nos meios que estes órgãos possam objetivar desenvolver.

As contribuições das ações comunicativas analisadas, tanto do Inca quanto do IBCC, para a melhoria da condição social da mulher ocorrem certamente, porém de maneira parcial,

\footnotetext{
${ }^{56}$ Serviço de monitoramento de propaganda e acervo publicitário - www.arquivo.com.br
} 
cada uma com suas limitações. O Inca atinge superficialmente seu público-alvo devido à baixa intensidade de ocorrência das suas ações; suas iniciativas na área de comunicação são poucas e sutis. Por outro lado, o IBCC possui uma campanha de alto nível de abrangência e extrema exposição midiática, mas a mensagem constituída descarta aspectos importantes como a prevenção e importantes informações de apelo.

De maneira geral, a prolixidade do discurso midiático sobre as mulheres contrasta com a ausência de informações precisas e circunstanciadas. Isso indica a necessidade da realização de ações estruturantes, qualificadas e de informação sobre os agravos mais comuns à saúde da mulher, assim como da disposição de orientações para sua promoção e prevenção de doenças.

Ao se deparar com a descoberta de carências informativas, percebe-se que estas envolvem o indivíduo e se projetam a cada dia numa escala maior e de expansão contínua. É somente no reconhecimento da realidade que o exercício da comunicação social, ou seja, da divulgação pública do que é relevante à comunidade, poderá acontecer, por meio da concepção elementar de simplesmente dizer o que tem que ser dito. 


\section{Referências Bibliográficas}

AAKER, David A. Criando e Administrando Marcas de Sucesso. São Paulo: Futura, 1996.

ADORNO, Theodor W. A Indústria Cultural. In: COHN, Gabriel (org.). Comunicação e Indústria Cultural. São Paulo: T.A. Queiroz, 1989.

ADORNO, Theodor W. HORKHEIMER, Max. Dialética do Esclarecimento: fragmentos filosóficos. Rio de Janeiro: Jorge Zahar Ed., 2006.

BARBOSA, Ana Maria de Souza. Viagem ao vale da morte: estudo psicológico sobre mulheres mastectomizadas por câncer de mama. Dissertação de mestrado. IP/USP, 2001. BARBOSA, Ivan Santo (org.). Sentidos da publicidade: os estudos interdisciplinares. São Paulo: Pioneira Thomson, 2005.

BEAUVOUIR, Simone. O segundo sexo - A Experiência Vivida. São Paulo: Difel, 1975.

BEAUVOIR, Simone. O Segundo Sexo - Fatos e Mitos. São Paulo: Difel, 1970.

BIEDERMANN, Hans. Dicionário Ilustrado de Símbolos. São Paulo: Melhoramentos, 1993.

BOSI, Ecléa. Cultura de massa e cultura popular: leituras de operárias. 10. ed. Petrópolis: Vozes, 2000.

BRANDÃO, Izabel. Corpo em Revista - Olhares Interdisciplinares. Maceió: Edufal Editora da Universidade Federal de Alagoas, 2005.

BRITO, Maria Fernanda Domingos de. A saúde da mulher na imprensa feminina. Dissertação de Mestrado. ECA/USP, 2001.

BUITONI, Dulcília Schroeder. Mulher de papel: a representação da mulher pela imprensa feminina brasileira. São Paulo: Loyola, 1981. 
Imagem da mulher na imprensa brasileira: é possível sair do padrão? Revista Brasileira da Biblioteca Mario de Andrade. São Paulo, v1, n.53, p.135-44, 1995.

CITELli, Adilson. Comunicação e educação. A linguagem em movimento. $3^{\mathrm{a}}$ ed. São Paulo: Senac, 2004.

COELHO NETO, J. Teixeira. Semiótica, Informação e Comunicação. São Paulo: Editora Perspectiva, 2001.

FARINA, Modesto, PEREZ, Clotilde, BASTOS, Dorinho. Psicodinâmica das Cores em

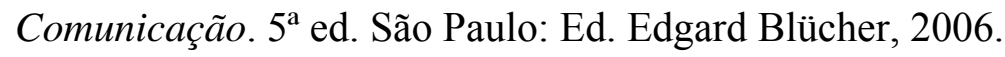

FIORIN, José Luiz. Linguagem e Ideologia. São Paulo: Editora Ática, 1988.

GARCIA, Denise Pedroso. O feminismo no bairro: a experiência da campanha pela prevenção do câncer de mama e de colo de útero na zona leste do município de São Paulo - 1994 a 1997. Dissertação de Mestrado. São Paulo, FFLCH/USP, 2002.

HELLER, EVA. Psicología del color. Como actúan los colores sobre los sentimentos y la razón. Barcelona: Editora Gustavo Gili, 2004.

IASBECK, Luiz Carlos Assis. A arte dos slogans. As técnicas de construção das frases de efeito do texto publicitário. São Paulo: Annablume, 2002.

KING, Samantha. Pink Ribbons, INC - Breast Cancer and the Politics of Philanthropy. Minnesota: University of Minnesota Press, 2006.

KUSHNER, Rose. Por que eu? O que toda mulher deve saber sobre o câncer de seio. São Paulo: Summus, 1981.

LIPOVETSKY, Gilles. A terceira mulher: permanência e revolução do feminino. São Paulo: Companhia das letras, 2000. 
MATTELART, Armand e Michele. História das teorias da comunicação. São Paulo: Ed. Loyola, 1999.

MATTELART, Michele. Mujeres e Industrias culturales. Barcelona: Editorial Anagrama, 1982.

MINISTÉRIO DA SAÚDE DO BRASIL. Secretaria de Atenção à Saúde. Instituto Nacional de Câncer. Coordenação de Prevenção e Vigilância. Estimativa 2006: Incidência de câncer no Brasil. Rio de Janeiro: INCA, 2008.

MORIN, Edgar. Cultura de Massas no Século XX. Vol. 1: Neurose. 9.ed. Rio de Janeiro: Forense Universitária, 2007.

Vol. 2: Necrose. 9.ed. Rio de Janeiro:

Forense Universitária, 2007.

PEREZ, Clotilde. Signos da marca: expressividade e sensorialidade. São Paulo: Thompson Learning, 2004. . A comunicação da completude: a busca do objeto de desejo. Revista Mackenzie Educação, Arte e História da Cultura, ano 3/4, n. 3/4, p. 109-116, 2003/2004. PEREZ, Clotilde e BAIRON, Sérgio. Comunicação e Marketing. São Paulo: Editora Futura, 2002.

PERROT, Michele. Minha história das mulheres. São Paulo: Editora Contexto, 2006.

PINOTTI, José Aristodemo. Saúde da mulher. São Paulo: Editora Contexto, 1994.

PRIORI, Mary Del. Mulheres no Brasil Colonial. São Paulo: Editora Contexto, 2000. .Corpo a Corpo com a mulher. São Paulo: Editora Contexto, 2000.

RELATÓRIO NOVEMBRO DE 2000. Viva Mulher. Programa Nacional de controle do colo do útero. Ministério da Saúde. Rio de Janeiro, 2000. 
RELATÓRIO VIVA MULHER. Câncer do Colo do Útero: Informações TécnicoGerenciais e Ações Desenvolvidas, Ministério da Saúde - Instituto Nacional de Câncer, Rio de Janeiro, 2002.

SEBESTA, Lithe e SPIEGEL, Maura. The Breast Book: An Intimate and Curious History. Workman Publishing Company, 2002.

SOMMER, Dr.Mateus. O Câncer de Mama. Rio de Janeiro: Editora Artenova, 1976.

SANT’ANNA, Armando. Propaganda: teoria, técnica e prática. São Paulo: Thompson, 2002.

SANTAELLA, Lucia. A percepção: uma teoria semiótica. São Paulo: Experimento. 2 ed., 1998.

Semiótica Aplicada. São Paulo, Thompson Learning, 2004.

A Teoria Geral dos Signos: como as linguagens significam as coisas. São Paulo, Pioneira Thomson Learning, 2004.

SANTAELLA, Lucia e Noth, Winfried. Imagem - cognição, semiótica, mídia. São Paulo: Ed. Iluminuras, 1998.

SONTAG, Susan. A doença como metáfora. 3. ed. São Paulo: Edições Graal, 2002.

TELES, Maria Amélia de Almeida. Breve História do Feminismo no Brasil. São Paulo: Editora Brasiliense, 1993.

TEMPORÃO, José Gomes. A propaganda de medicamentos e o mito da saúde. Rio de Janeiro: Edições Graal, 1986.

ZECCHIN, Rubia Nascimento. A perda do seio: um trabalho psicanalítico institucional com mulheres com câncer de mama. São Paulo: Educ, 2004.

WOLF, Naomi. O Mito da Beleza. Rio de Janeiro: Editora Rocco, 1991.

YALOM, Marilyn. História do Seio. Lisboa: Editorial Teorema, 1998. 
$\underline{\text { Referências consultadas da internet: }}$

Assembléia Legislativa do Estado de São Paulo:

http://www.al.sp.gov.br/portal/site/alesp

Informações sobre Câncer de Mama:

http://www.cancerdemama.com.br

http://www.cancerdemama.org.br

Instituto Brasileiro de Controle do Câncer:

http://www.ibcc.org.br

Instituto Nacional do Câncer:

http://www. inca.gov.br

World Economic Forum

http:// www.weforum.org

Presidência da Republica Federativa do Brasil:

http://www.datasus.gov.br

http://www.presidencia.gov.br

http:// www.presidencia.gov.br/spmulheres

http://www.portalsaude.gov.br 
Anexos 


$$
\text { 1- IBCC }
$$




\section{Contra o câncer de mama, use algodão.}

Pesquisas comprovam alguns cortes de algodāo com um alvo azul no meio sâo muito eficazes no com bate ao cancer de mam Caima, é fácil de entendé Com a venda da cam! do alvo, o IBCC - Instit Brasileiro de Controlo ut Cancer - arrecada recursos para comprar equipamentos médicos de última geraçāo, ampliar e manter o hospital e atender pessoas carentes sem cobrar nada. Como vocè vê, nấo é à toa que estamos indicando a camiseta do alvo para todo mundo. Compre uma e participe da campanha "O Cancer de Mama no Alvo da Moda - Brasil II". Vocé ajuda o IBCC, recebe um cartao de auto-exame e mostra que tem peito.

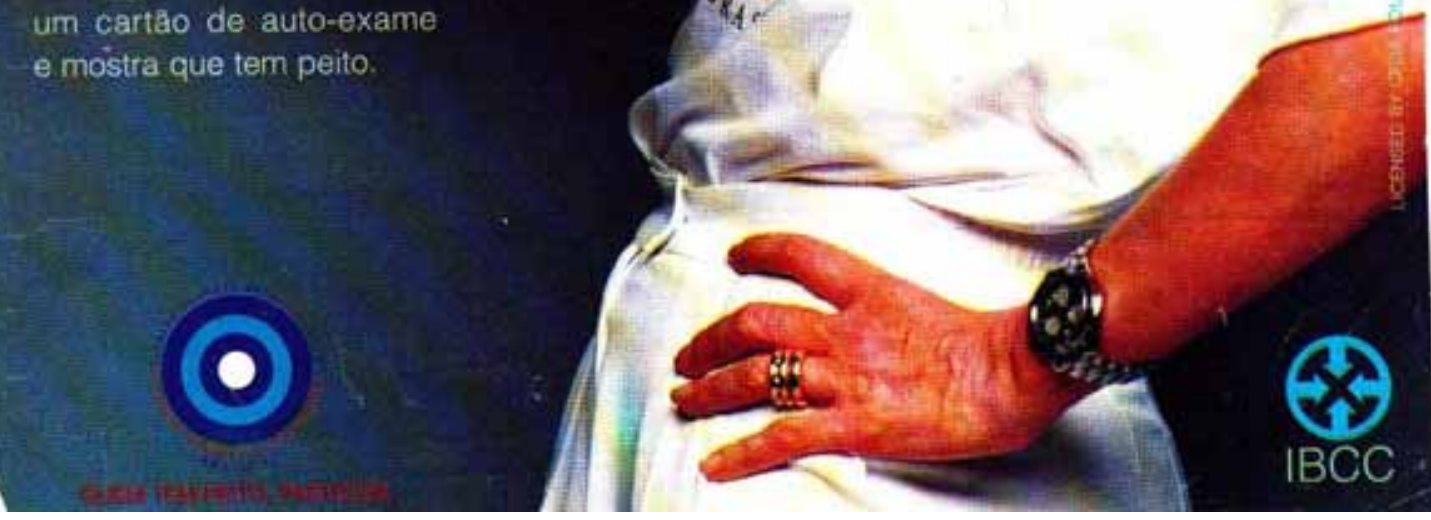

I - ANÚNCIO DA CAMPANHA O CÂNCER DE MAMA NO ALVO DA MODA 


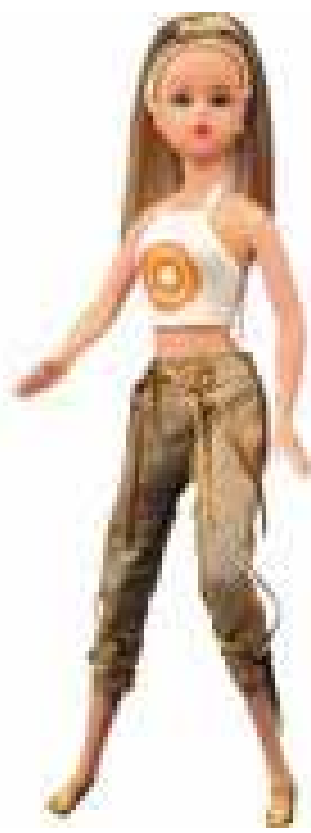

II - BONECA SUSI COMERCIALIZADA COM A MARCA IBCC

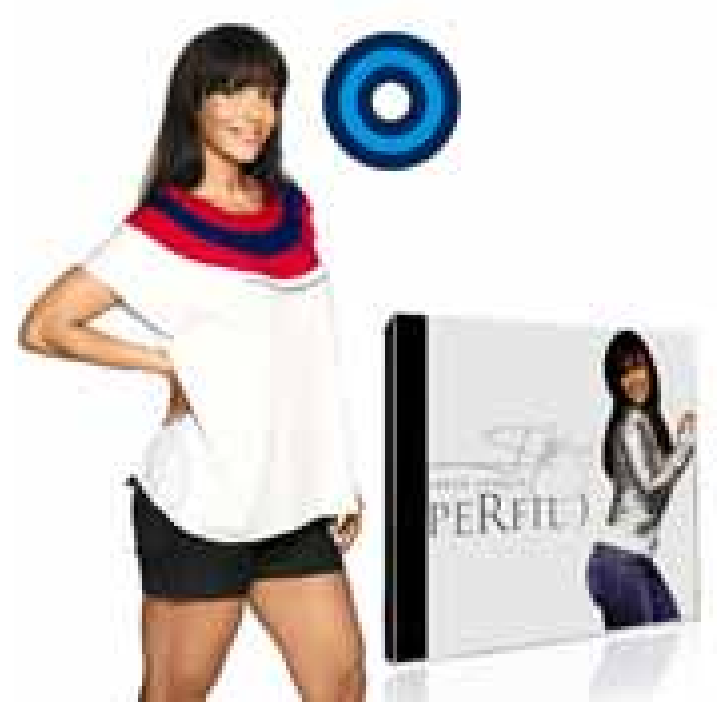

III - KIT CAMISETA E CD DA CANTORA IVETE SANGALO COM A MARCA IBCC 


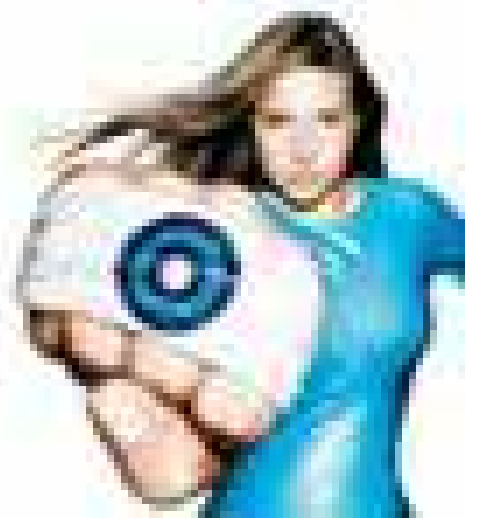

IV - EXEMPLO DE FUNDO DE TELA PARA COMPUTADOR DA MARCA IBCC

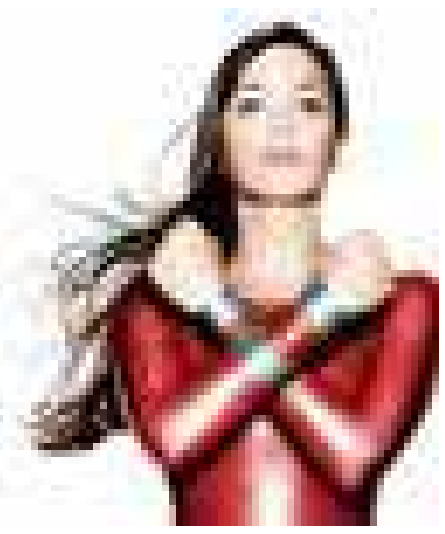

V - EXEMPLO DE FUNDO DE TELA PARA COMPUTADOR DA MARCA IBCC 

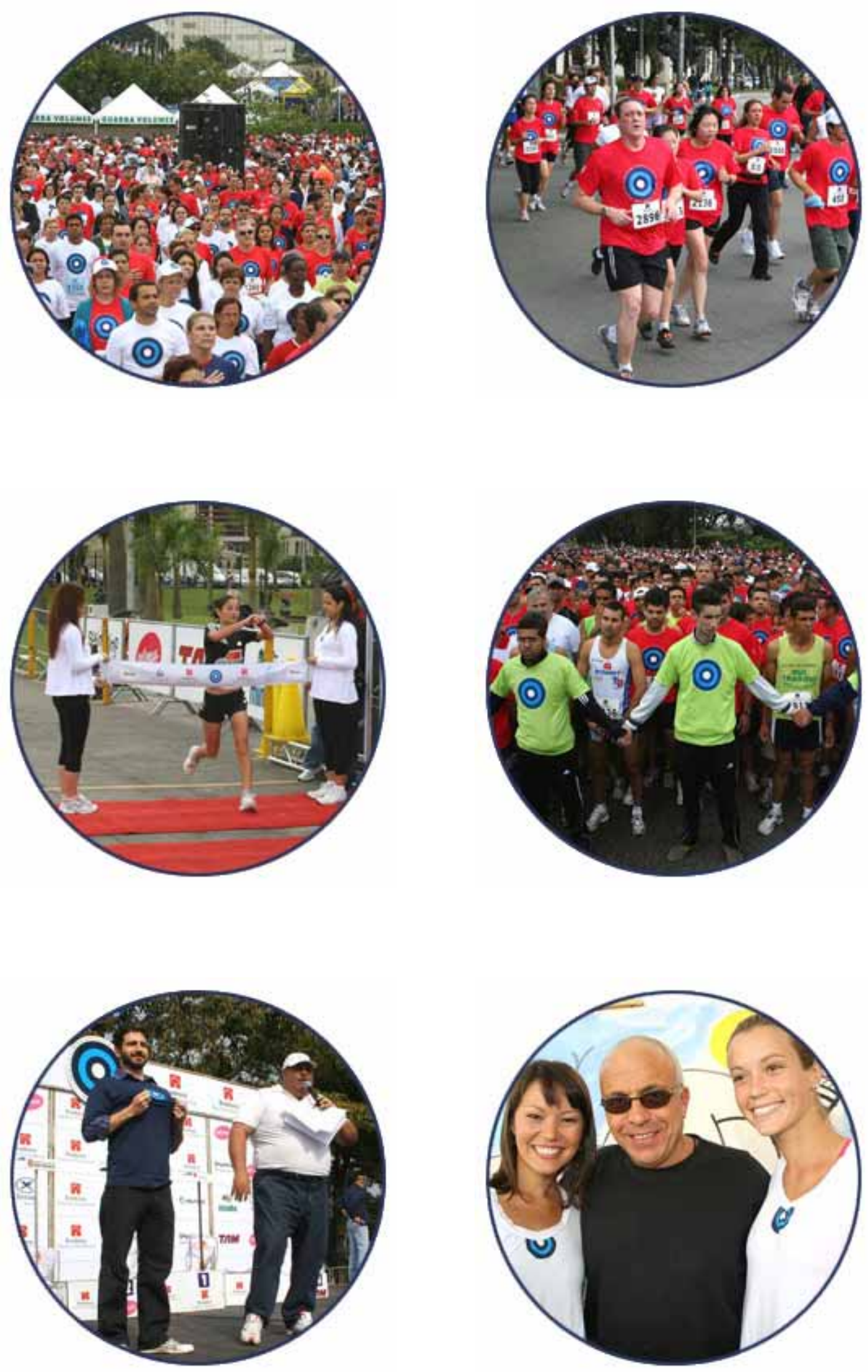

VI- FOTOS DA CORRIDA E CAMINHADA CONTRA O CÂNCER DE MAMA DO IBCC SÃO PAULO, 2008 
2 - Inca 


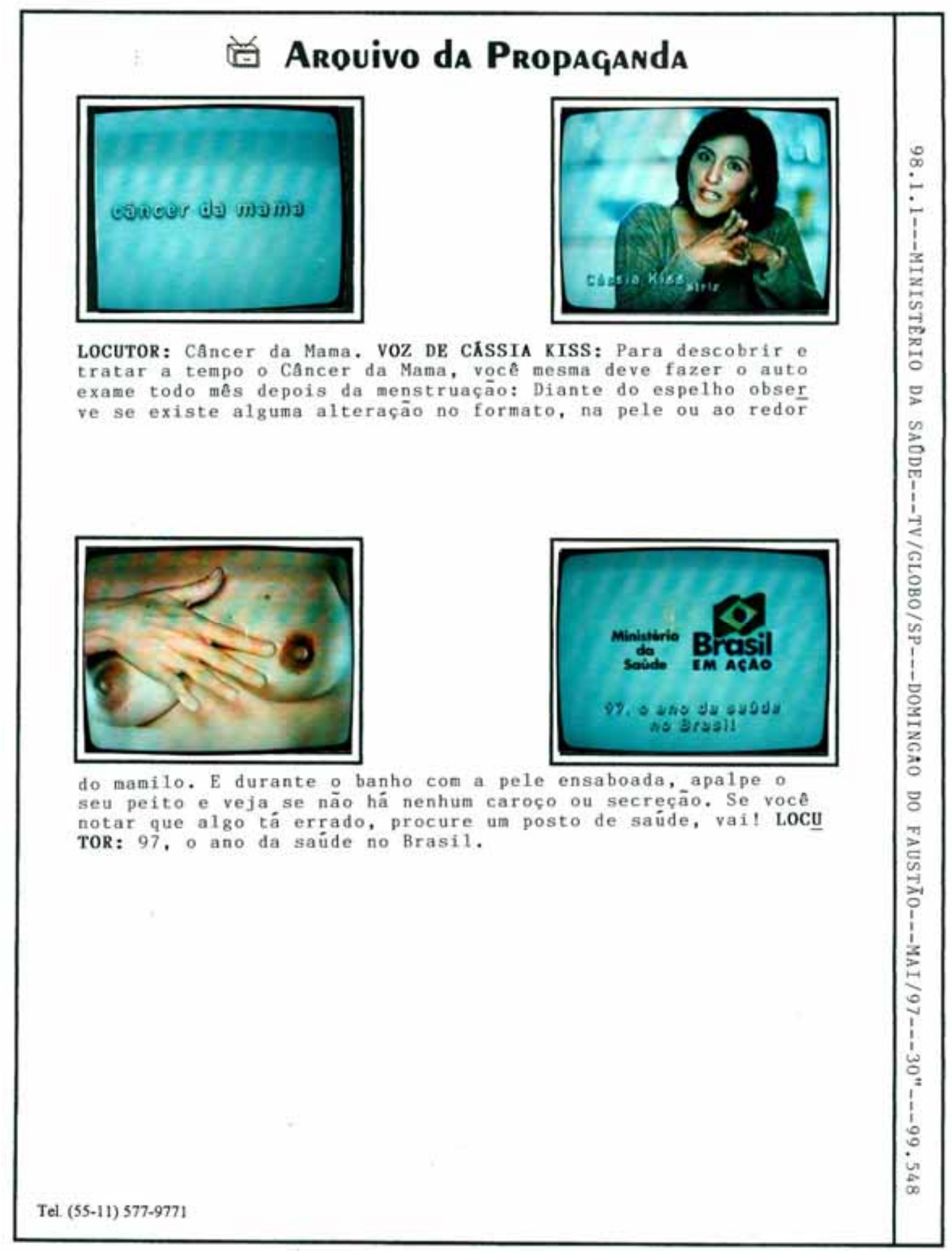

I - CLIPBOARD DO VÍDEO UM TOQUE DE VIDA- MINISTÉRIO DA SAÚDE, 1997 VEICULADO NO PROGRAMA DA REDE GLOBO DOMINGÃO DO FAUSTÃO 

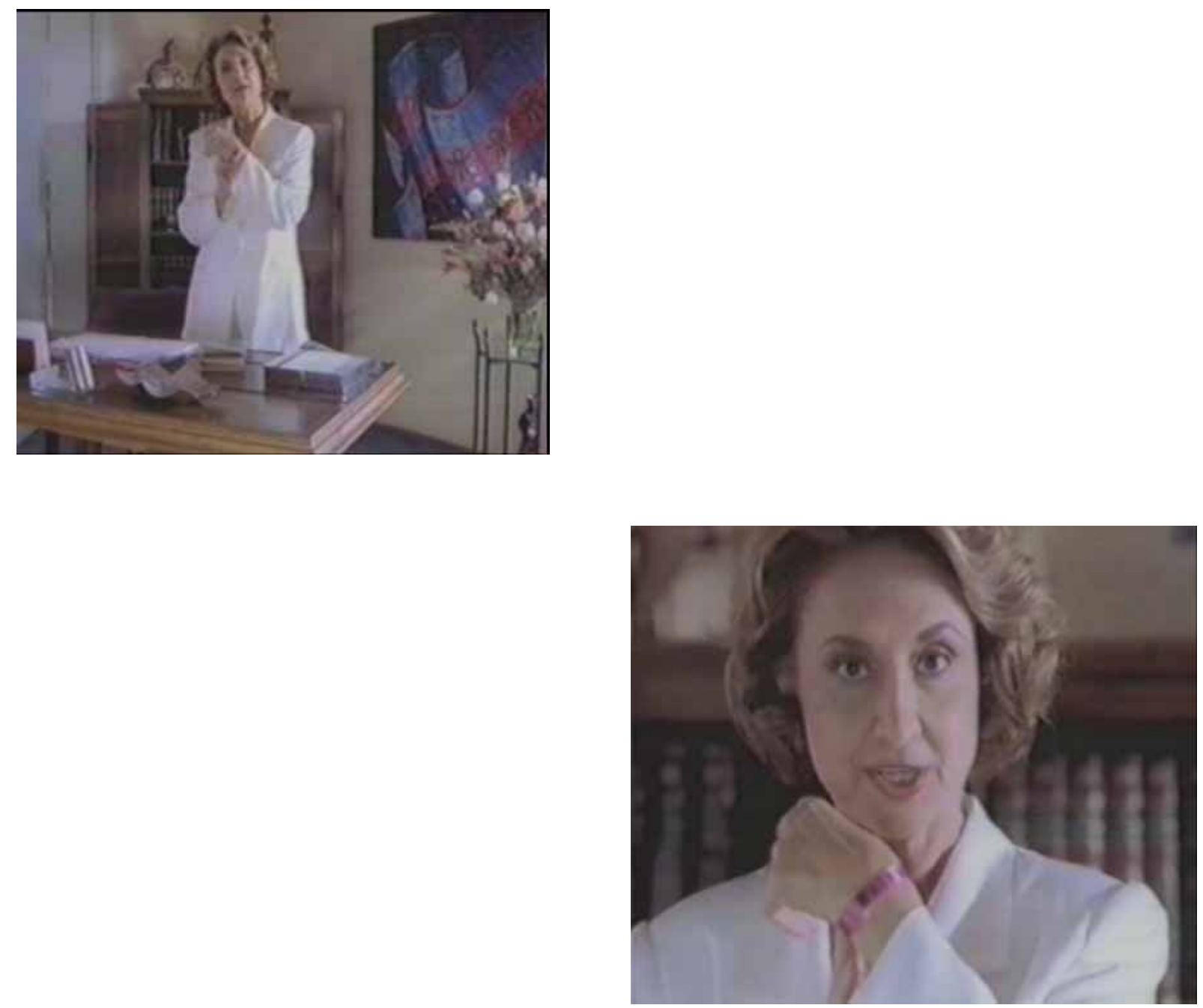

YHAA DOENEA

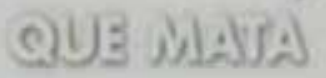

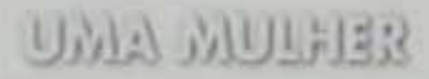
A SADA J FOR:A 320 illvuros. 

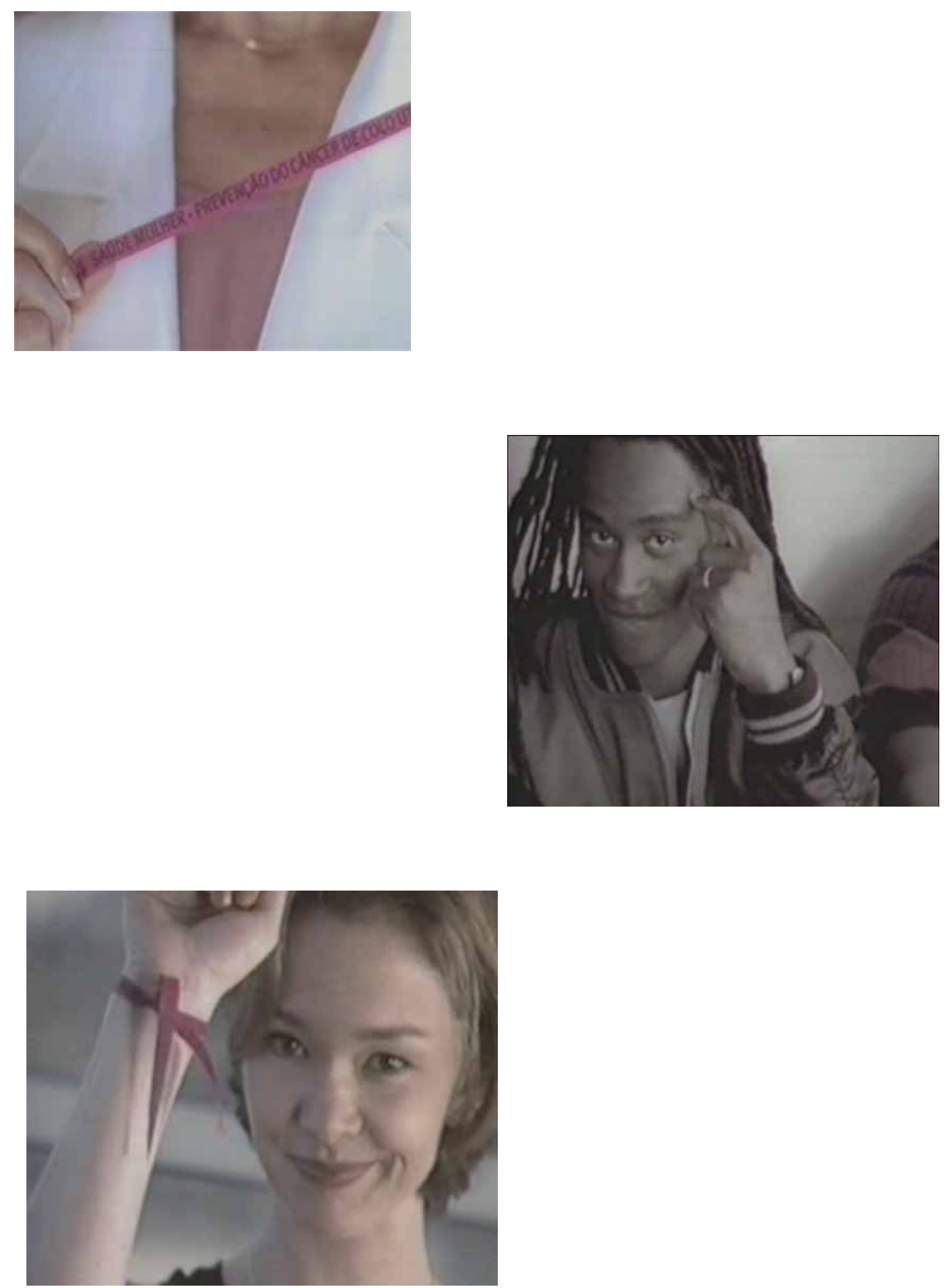

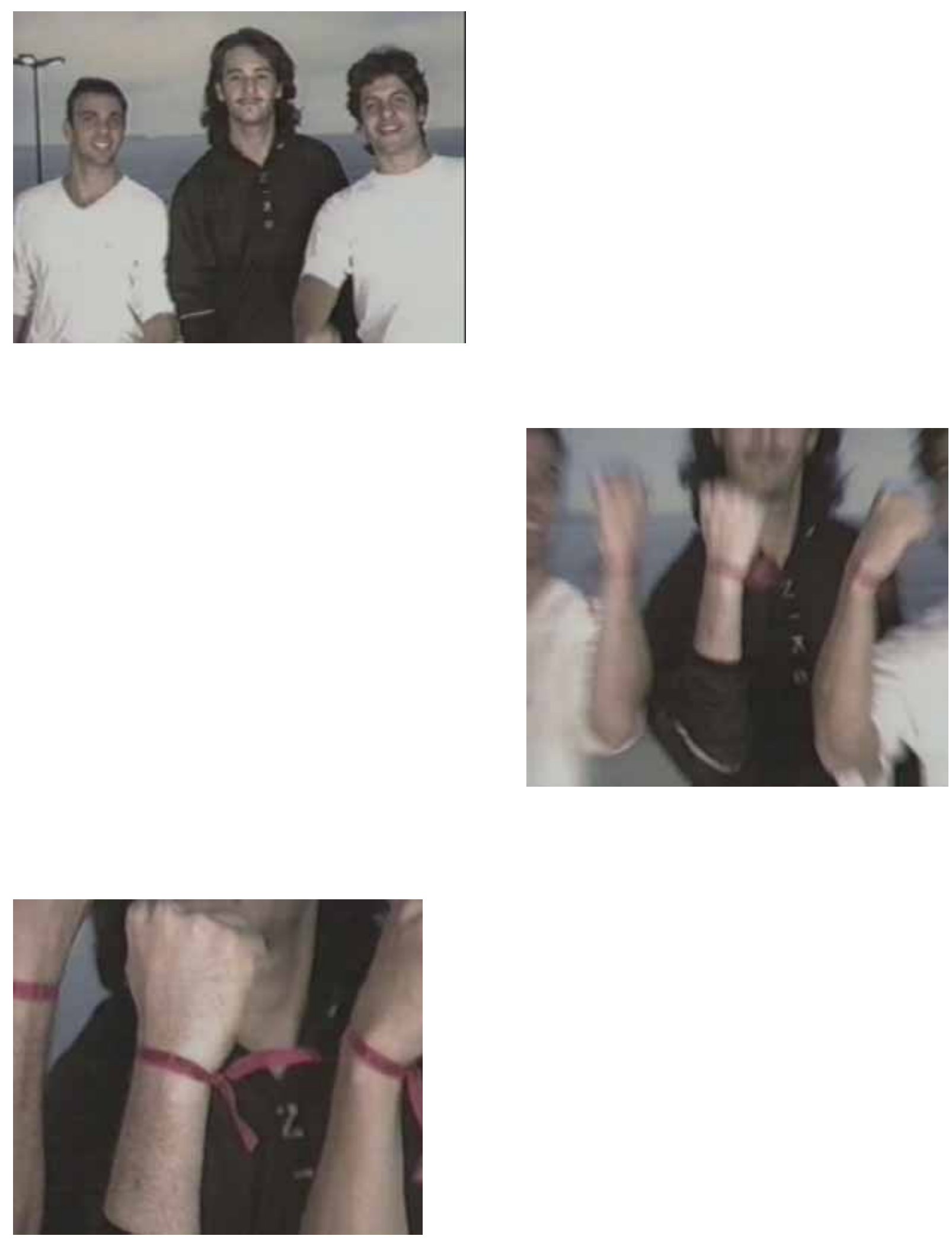

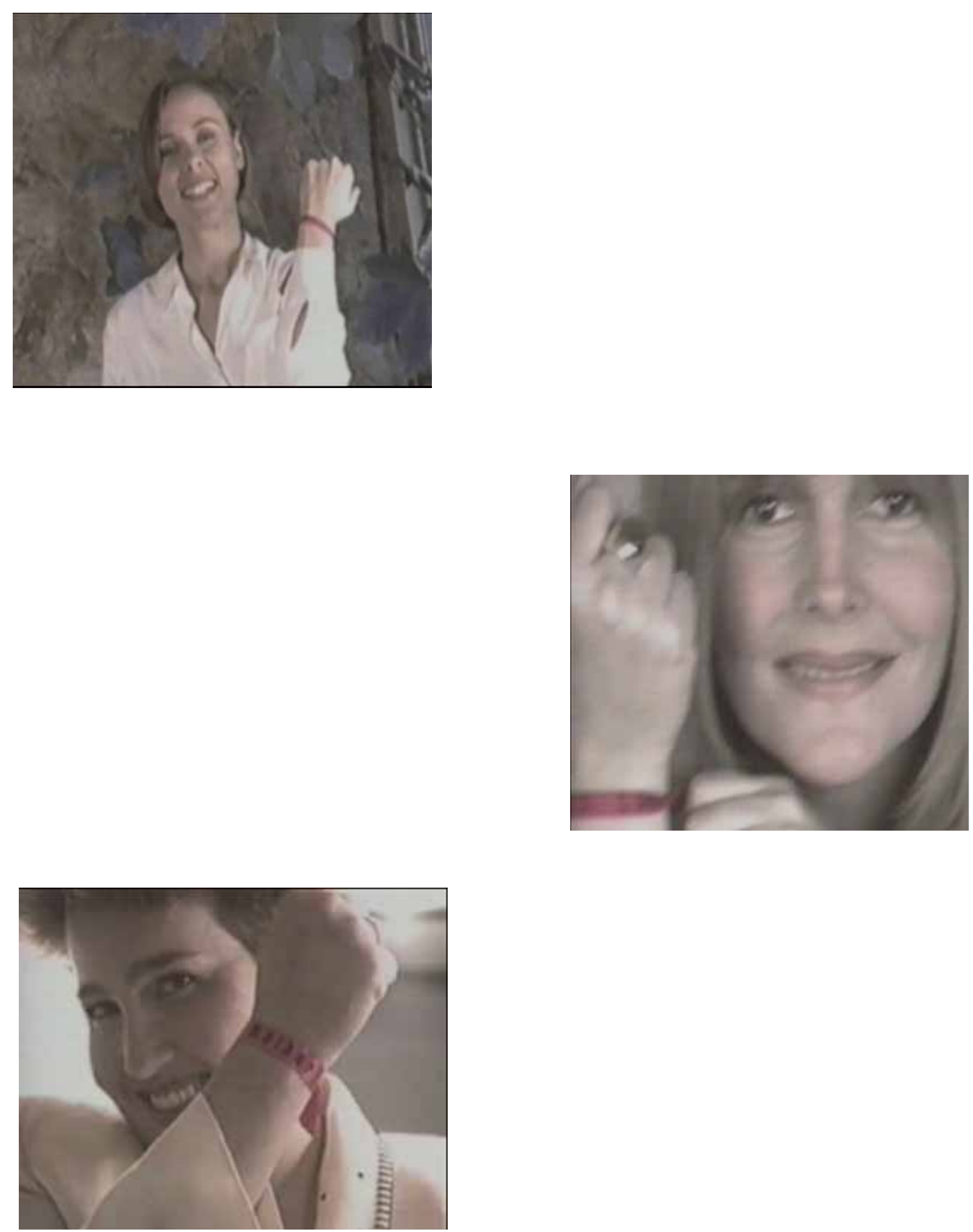

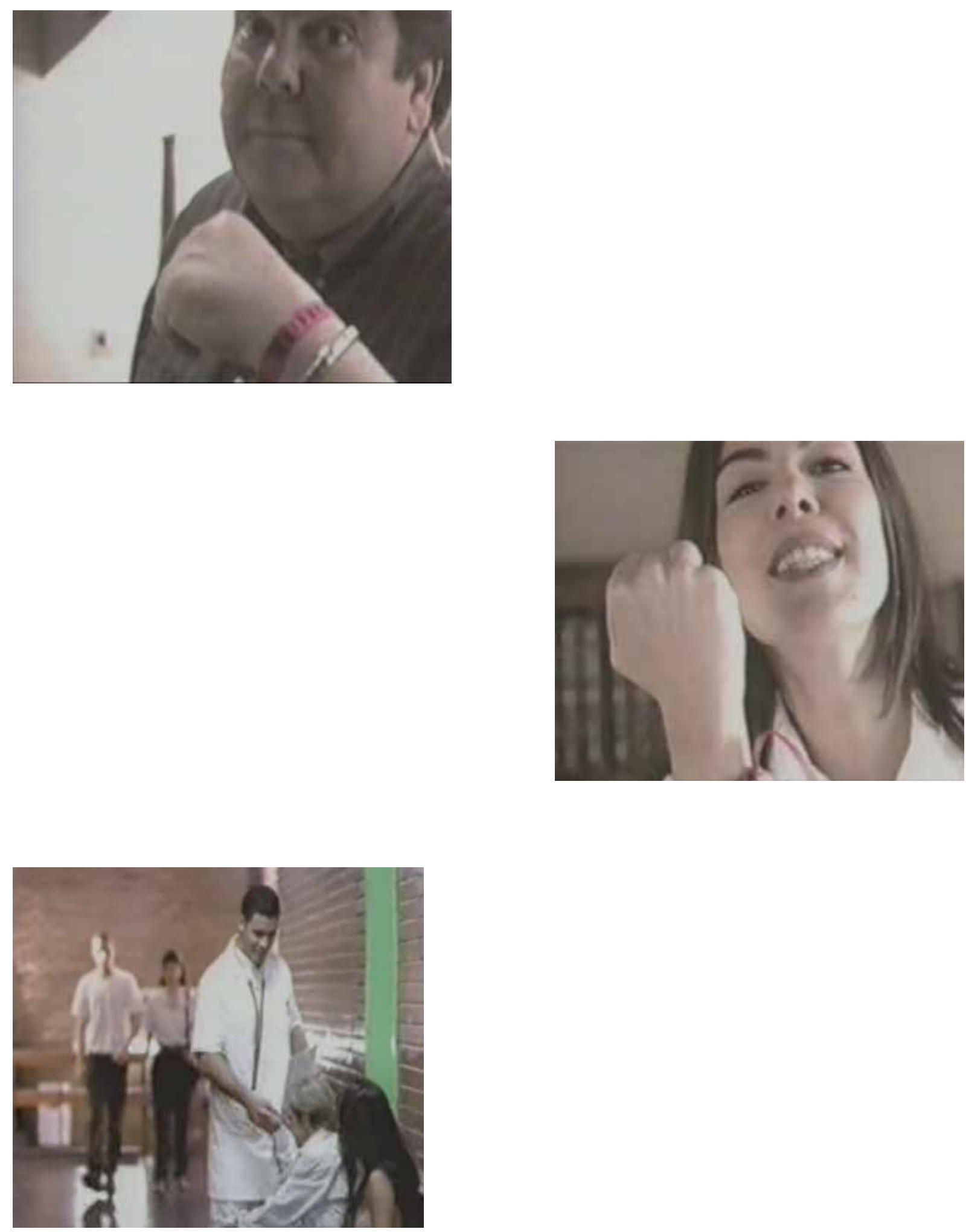

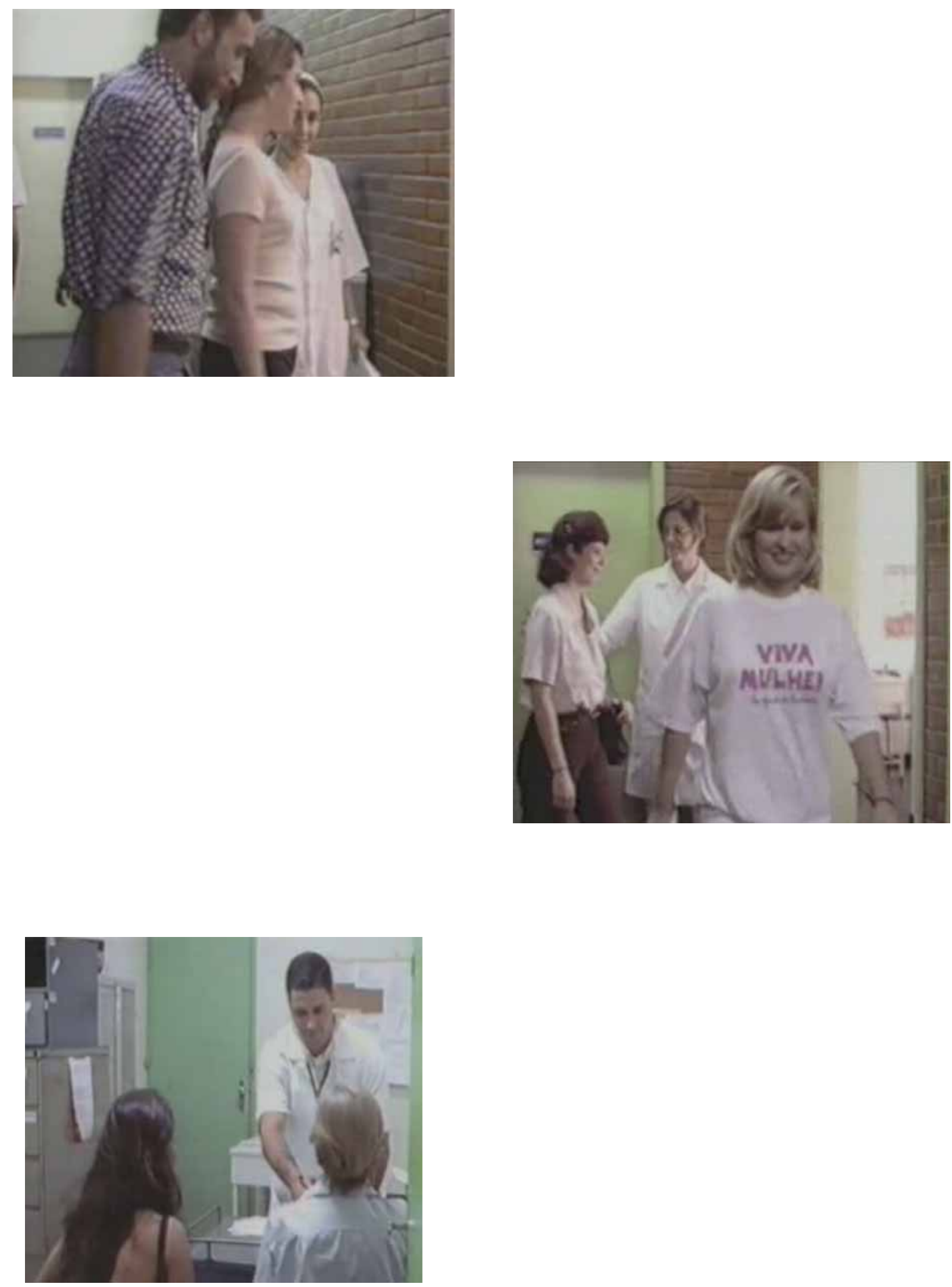

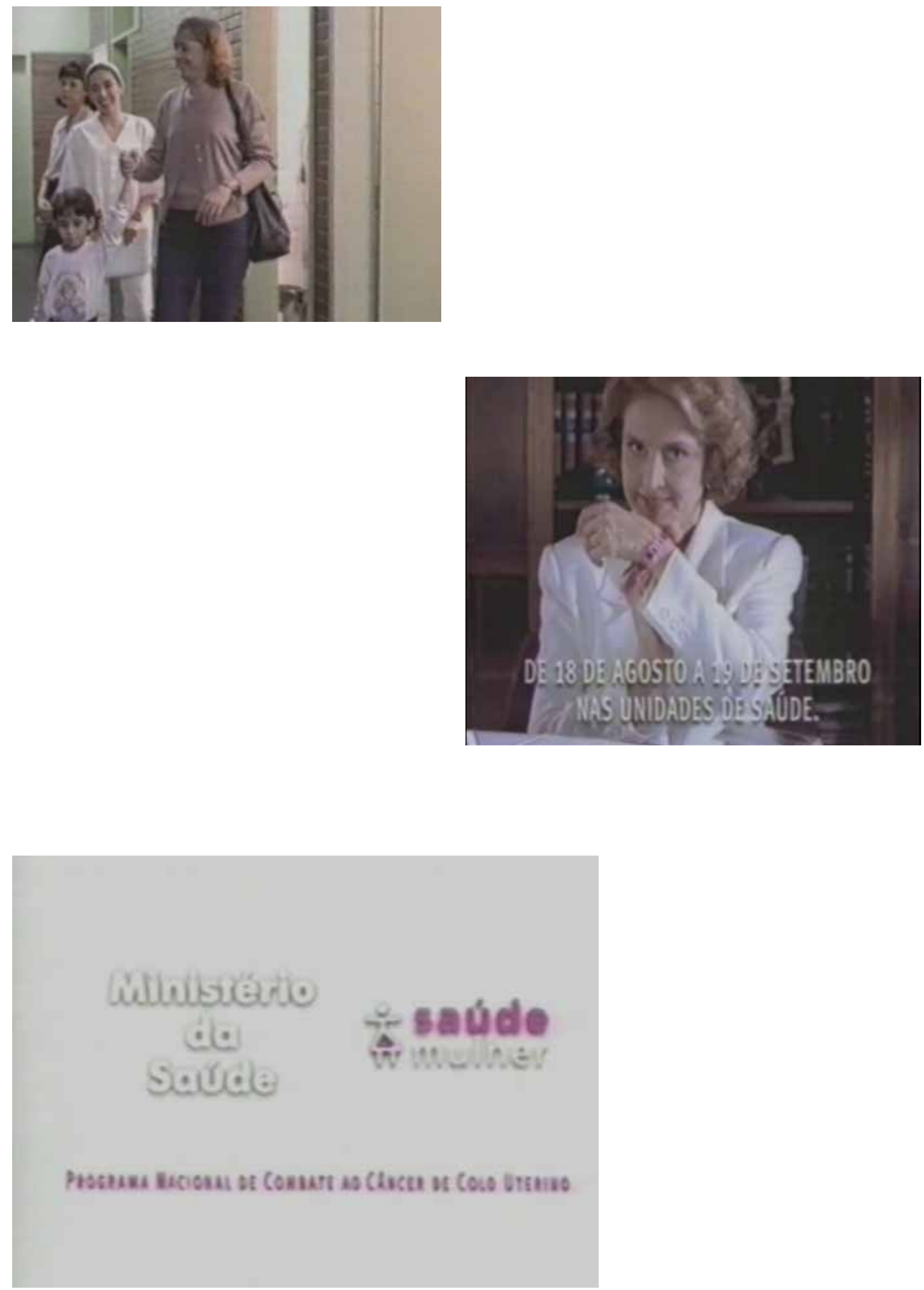

II - CENAS DO VÍDEO DA CAMPANHA VIVA MULHER - MINISTÉRIO DA SAÚDE, 1998 VEICULADO NO PROGRAMA DA REDE GLOBO JORNAL NACIONAL 


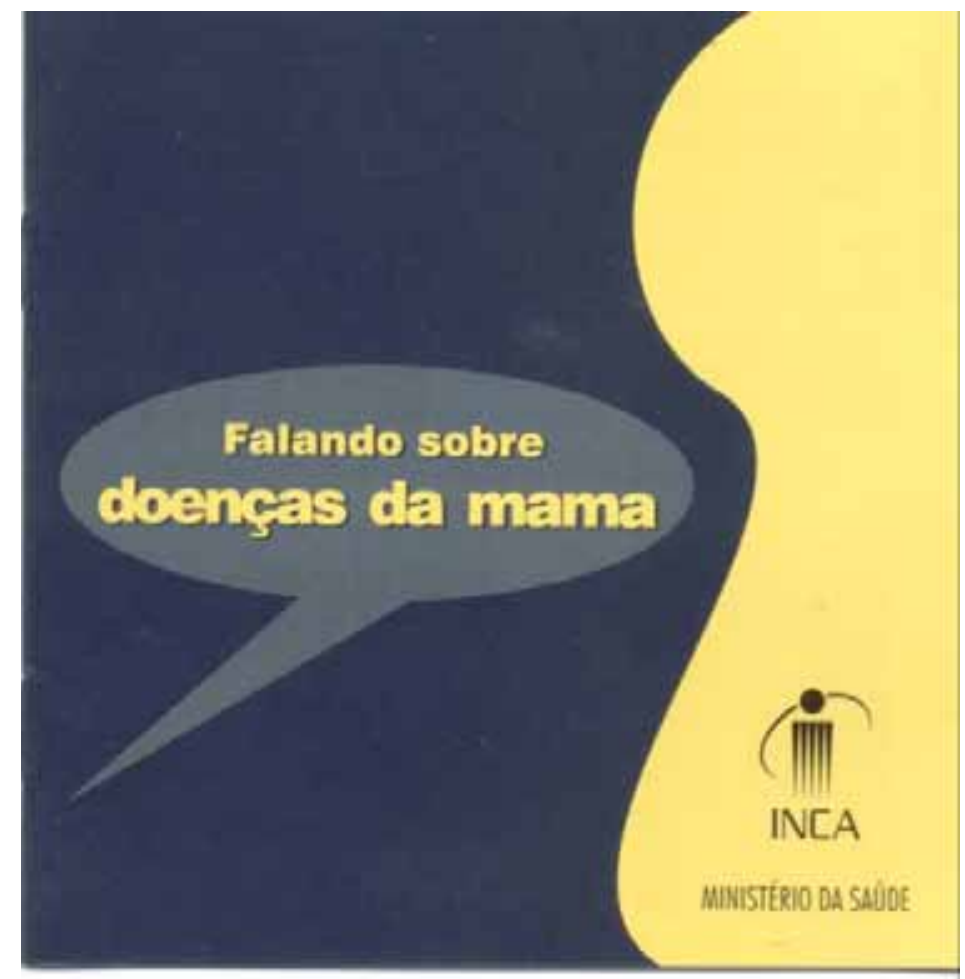

III - CD DE MATERIAL TÉCNICO DIVULGADO PARA PROFISSIONAIS DE SAÚDE

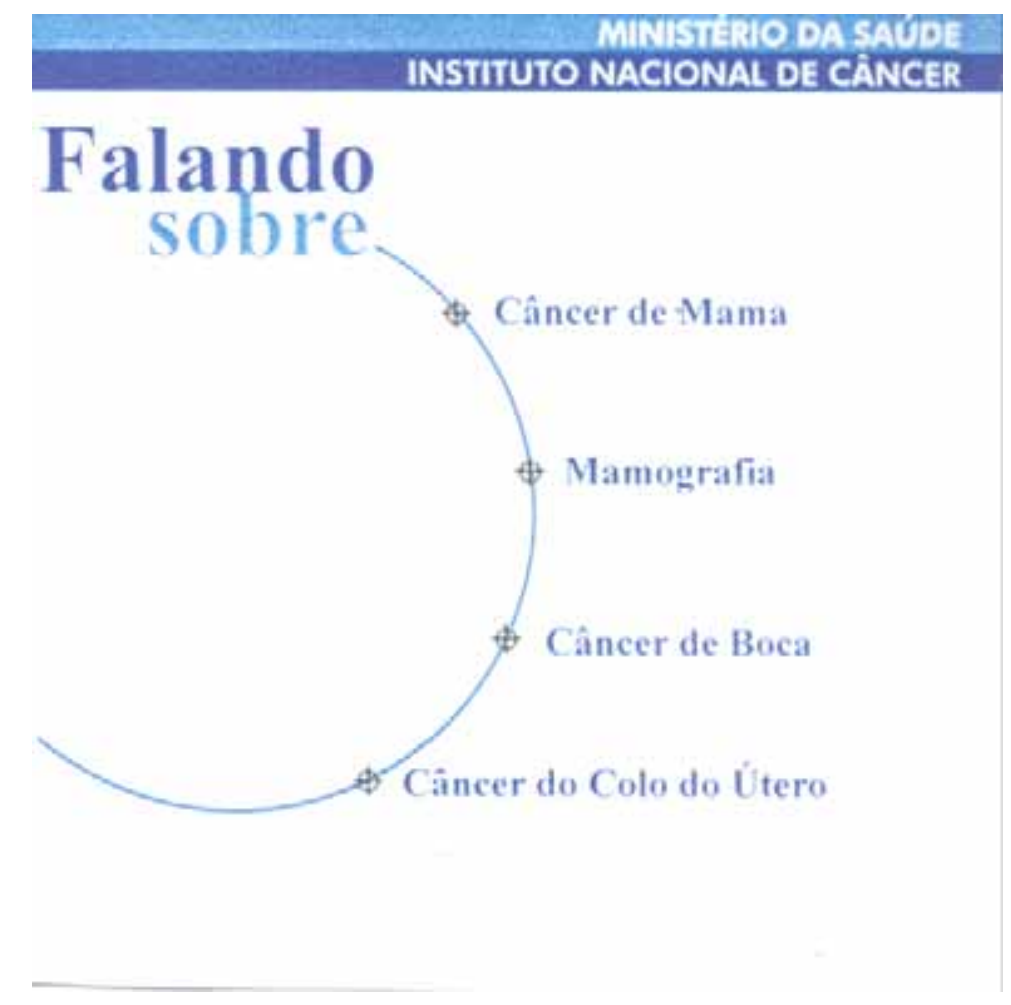

IV - CD DE MATERIAL TÉCNICO DIVULGADO PARA PROFISSIONAIS DE SAÚDE 
PARÂMETROS TÉCNICOS PARA PROGRAMAÇÃO DE AÇÕES DE DETECCĀO PRECOCE DO CÂNCER DA MAMA

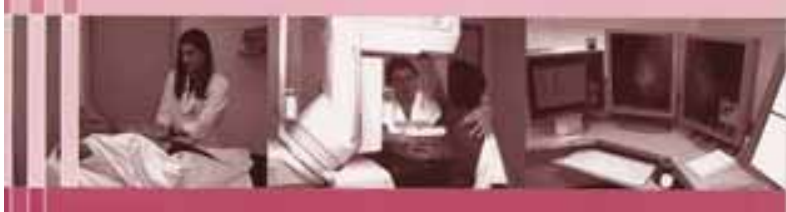

Recomendaçōes para Gestores Estaduais e Municipais

\section{INCA}

V - APOSTILA DE MATERIAL TÉCNICO DIVULGADA PARA PROFISSIONAIS DE SAÚDE - CAPA

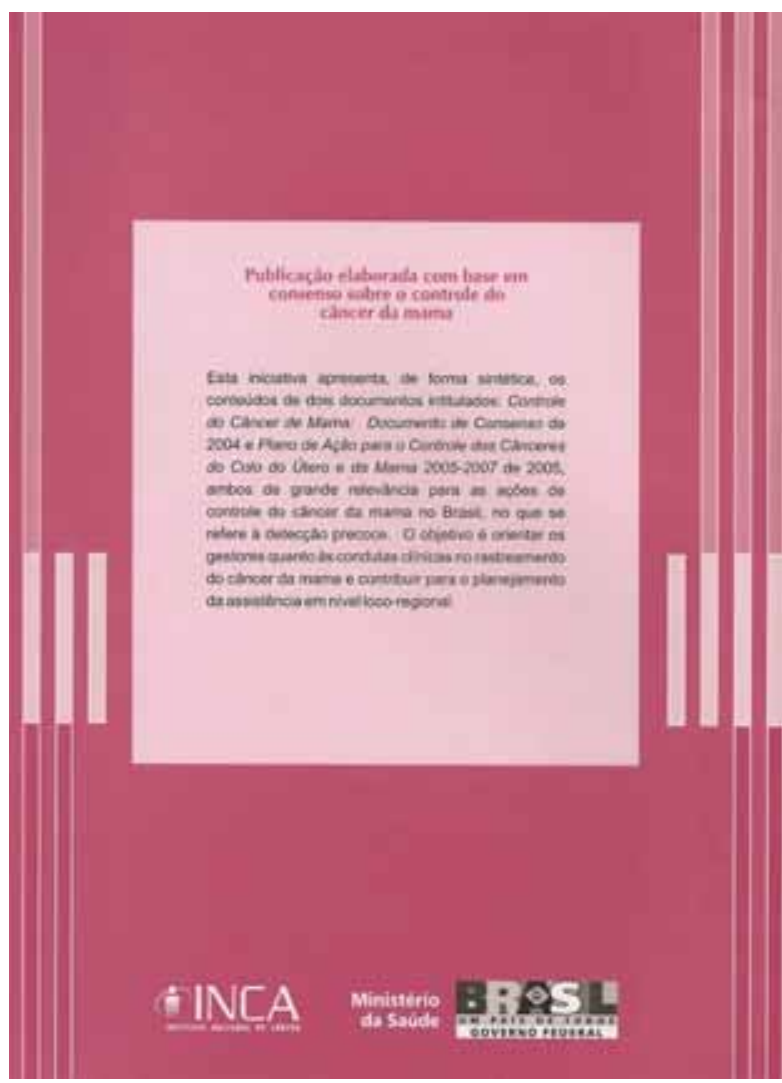

VI - APOSTILA DE MATERIAL TÉCNICO DIVULGADA PARA PROFISSIONAIS DE SAÚDE - VERSO 


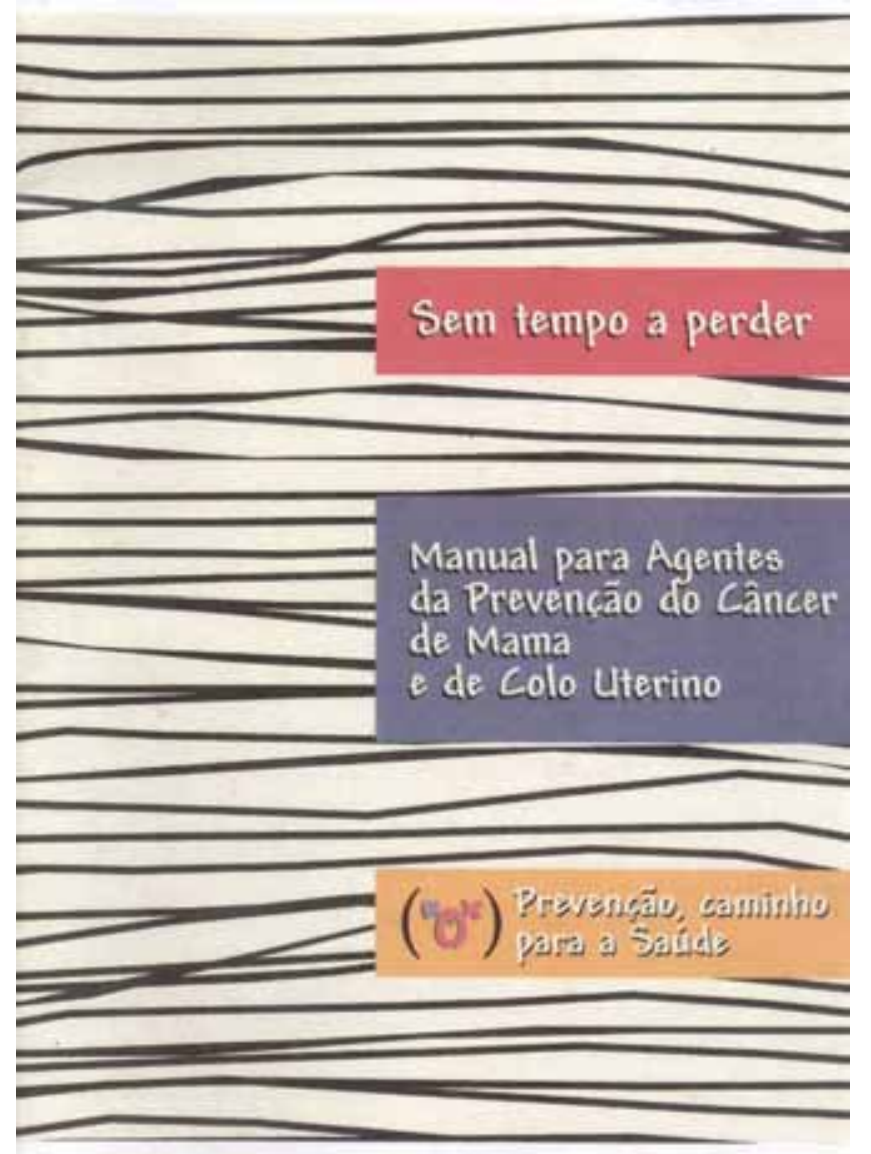

VII - APOSTILA DE MATERIAL TÉCNICO DIVULGADA PARA PROFISSIONAIS DE SAÚDE - CAPA

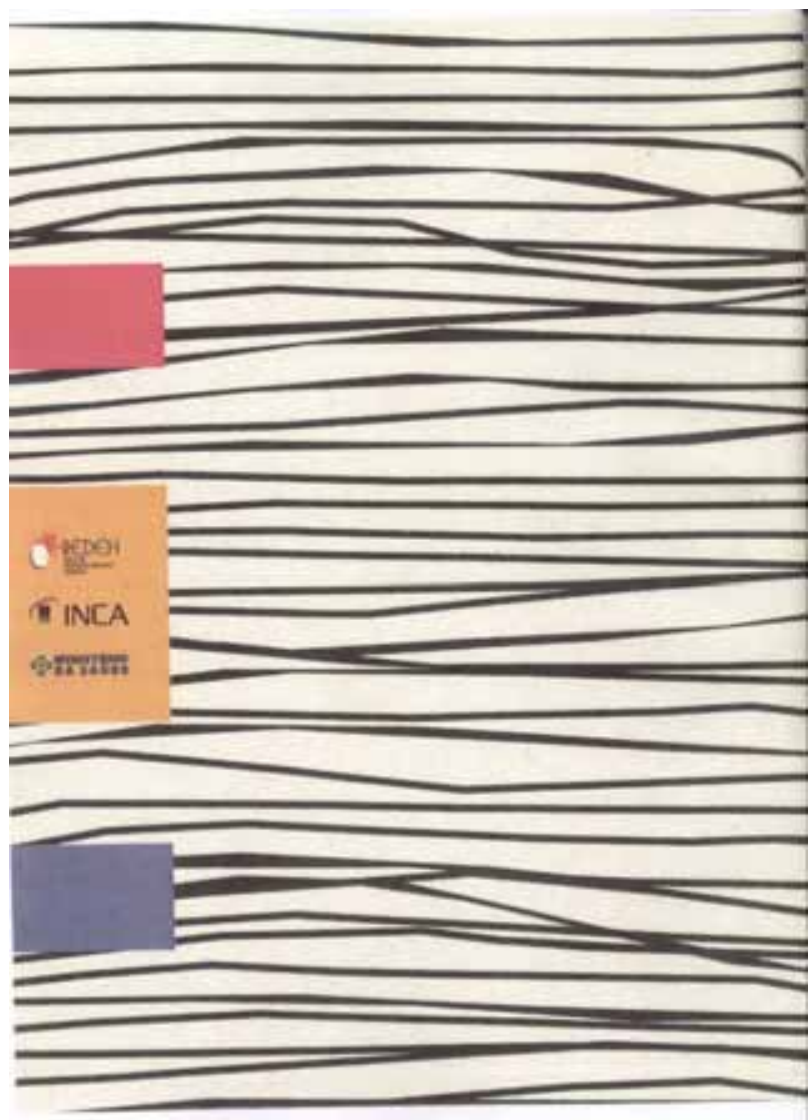

